\title{
Palladium-Catalyzed Oligocyclizations of Some 2-Bromotetradec-1-ene-7,13-diynes Under Heck Reaction Conditions
}

\author{
Dissertation \\ Zur Erlangung des Doktorgrades der Mathematisch-Naturwissenschaftlichen Fakultäten \\ der Georg-August-Universität zu Göttingen
}

vorgelegt von

Wajdi Mohammad Izzat Tokan

aus Amman/Jordan

Göttingen 2002 
D7

Referent: Prof. Dr. A. de Meijere

Korreferent: Prof. Dr. Ulf Diederichsen

Tag der mündlichen Prüfung: 30.01.2003 
Ich möchte an dieser Stelle meinem Lehrer, Herrn Prof. Dr. Armin de Meijere, danken für die interessante Themenstellung, die Unterstützung und die vielen Anregungen und Diskussionen während der Promotionszeit. 
To my parents 


\section{Contents}

A. Introduction 1

1. Cross-coupling reactions 1

2. Cycloisomerizations 2

3. Heck reactions 4

4. Cascade reactions 6

B. Main Part 11

1. Palladium-catalyzed oligocyclization of 2-bromo14-phenyltetradec-1-ene-7,13-diyne 11

1.1. Prologue 11

1.2. Synthesis of phenyl-substituted precursors $\quad 14$

1.3. Palladium-catalyzed oligocyclizations of 19 phenyl substituted precursors

2. Palladium-catalyzed oligocyclization of 2-bromo-14- 21 tert-butyldimethylsilyltetradec-1-ene-7,13-diyne

2.1. Prologue 21

2.2. Synthesis of tert-butyldimethylsilyl-substituted precursors 22

2.3. Palladium-catalyzed oligocyclizations of 26 tert-butyldimethylsilyl-substituted precursors

3. Palladium-catalyzed oligocyclization of terminally 31 alkoxycarbonyl-substituted of 2-bromotetradec-1-ene-7,13-diynes

3.1. Prologue 31

3.2. Synthesis of the alkoxycarbonyl-substituted precursors 33

3.3. Palladium-catalyzed oligocyclizations of 37 alkoxycarbonyl-substituted precursors

3.4. The mechanism of the palladium-catalyzed oligocyclization of the 40 alkoxycarbonyl-substituted precursors

4. Palladium-catalyzed oligocyclization of terminally 42 alkoxycarbonyl-10-(2-bromoallyloxy)-1,7-decadiyne 
4.1. Prologue 42

4.2. Synthesis and oligocyclization of the alkoxycarbonyl-substituted 43 heteroatom-tethered precursor

4.3. The mechanism of the palladium-catalyzed oligocyclization of the heteroatom-tethered precursor

5. Palladium-catalyzed oligocyclization of terminally acetyl-substituted 2-bromotetradeca-1-ene-7,13-diynes

5.1. Synthesis of acetyl-substituted precursors

5.2. Palladium-catalyzed oligocyclizations of the acetyl-substituted precursors and their mechanism

6. Palladium-catalyzed oligocyclization of 2-bromotetradec-1-ene-7,13-diyne

7. Summary for the synthesis of the precursors 60

8. Summary of the mechanistic aspects 63

C. Experimental Part $\quad 65$

1. General notes 65

2. General procedures 66

3. Synthesis of the precursors $\quad 70$

4. Palladium-catalyzed oligocyclizations 96

$\begin{array}{ll}\text { D. Conclusion and abstract } & \mathbf{1 1 3}\end{array}$

E. References and Literature $\quad 116$

$\begin{array}{ll}\text { F. Spectral Data } & 120\end{array}$ 


\section{A. Introduction}

Reactions involving the formation of a carbon-carbon bond are considered the most valuable reactions in organic chemistry. Organometallic reagents, such as grignad reagents and organolithium reagent, were among the earliest tools in this regard. Until the sixties of the last century, the synthetic utility of these reagents had, however, been so constrained due to their poor chemoselectivity and to their limited use to form only a $\mathrm{sp}^{3}$ $\mathrm{sp}^{3}$ carbon-carbon bond. The plethora in organometallic chemistry and organotransition metal chemistry had culminated in developing new reagents and catalysts which opened the door for new precious transformations and reactions which had been considered as impossible or difficult to obtain. They have also expanded the utility of the old organometallic reagents by improving their selectivity and the scope of their use. ${ }^{[1]}$ In this introduction, four processes of these transition-metal catalyzed processes are going to be mentioned; these are cross-coupling reaction of organometallic compounds with organic halides, cycloisomerization reactions, Heck reaction and cascade reactions. Our major concern would be on the last two because they are the subjects of this study.

\section{Cross-Coupling Reactions}

Cross coupling reactions of organometallic compounds with organic halides were among the most extensively studied reactions. Thus by the advent of the new transition metal catalysts, cross-coupling reactions involving the formation of $\mathrm{sp}^{2}-\mathrm{sp}^{2}$ or $\mathrm{sp}^{2}-\mathrm{sp}$ carboncarbon bonds have become widely used reactions. Reactions such as Stille coupling, ${ }^{[2]}$ Sonogashira reaction ${ }^{[3]}$ and Suzuki coupling ${ }^{[4]}$ have now become essential and prominent reactions in organic chemistry, (Scheme 1.).

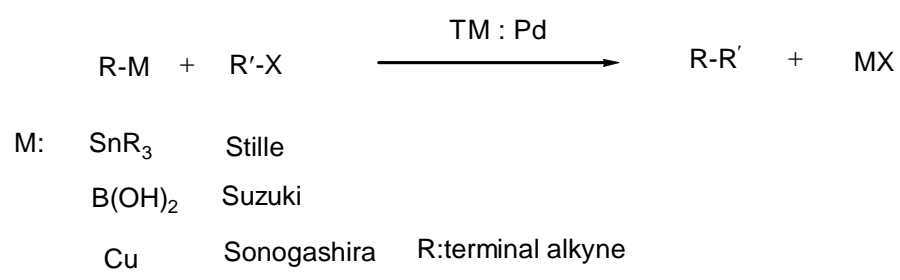

Scheme 1. 


\section{Cyclisomerization}

Alder-ene reaction, ${ }^{[5]}$ (Scheme 2), is just another impressive example wherein the transition-metal catalysts played a very important role. Although of its great importance, this reaction had found a limited use due to the high temperatures required to induce this transformation. However, by using catalytic amounts of lewis acids ${ }^{[6]}$ or transition-metal compounds, this transformation can smoothly be performed at room temperature. Thus 1,n-diene, 1,n-enyne and 1,n-diyne cycloisomerizations have become easily accessible and feasible processes and they emerged as an extremely efficient way in constructing cyclic compounds which are difficult to obtain by the traditional methods.

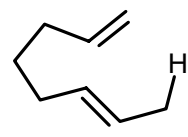

1

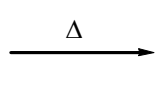

$(\mathrm{dba})_{3} \mathrm{Pd}_{2} \cdot \mathrm{CHCl}_{3}$

$\mathrm{PhH}, 60^{\circ} \mathrm{C}$

$76 \%$

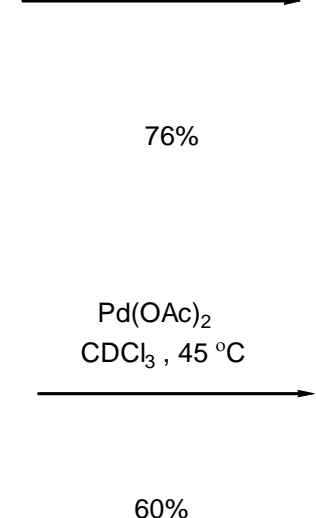

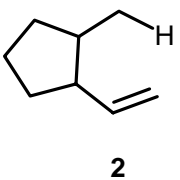

2

Scheme 2.

Scheme 3 illustrates two examples of $1,6^{[7]}$ - and $1,7^{[8]}$ - enyne palladium-catalyzed cycloisomerization to afford the five- and six-membered ring systems with 1,3-diene moieties 4,6.

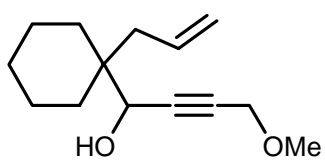

3

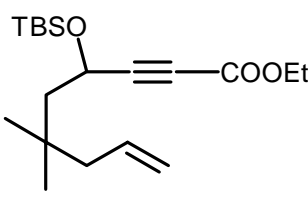

5

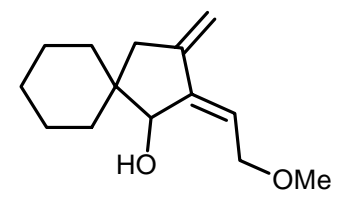

4

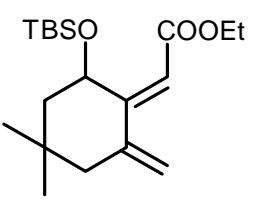

6

Scheme 3.

Consequently, the formation of 1,3diene systems opens the door for Diels-Alder reaction as a suitable subsequent reaction, ${ }^{[9]}$ (Scheme 4). 


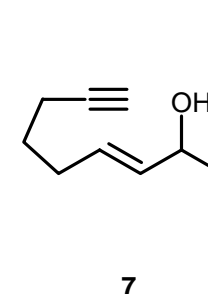

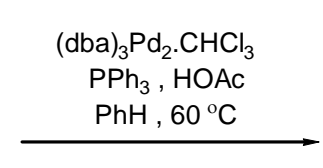

$66 \%$

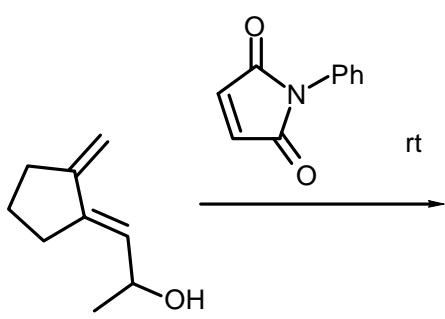

8

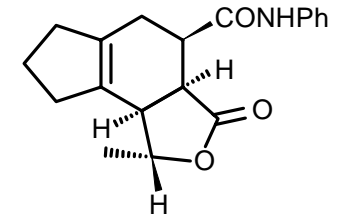

9

Scheme 4.

More interestingly, a sequence of 1,6-enyne palladium-catalyzed cycloisomerization and Diels-Alder reaction can take place in an intra-intra molecular fashion to produce a tricyclic system from an open chain precursor in a single step, ${ }^{[9]}$ (Scheme 5).

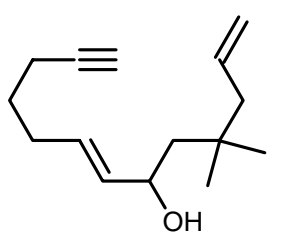

10

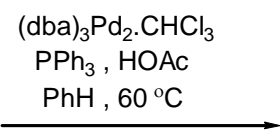

$72 \%$<smiles>C=CCC(C)(C)CC(O)C=C1CCCC1=C</smiles>

11

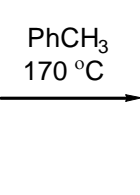

$74 \%$<smiles>CC1(C)C[C@H](O)[C@H]2C3=C(CCC3)CC[C@H]2C1</smiles>

12

Scheme 5.

Albeit palladium-catalyzed 1,7-enyne cycloisomerizations to form six-membered systems are feasible processes, they are less efficient than the palladium-catalyzed 1,6-enyne cycloisomerizations which lead to the formation of five-memberd ring systems. ${ }^{[10]}$ Nevertheless, such processes can be induced more efficiently by using Ni-Cr catalyst ${ }^{[11]}$.

Even though palladium has been the most extensively studied and used metal to induce such transformations, other metals such as Fe, ${ }^{[12]} \mathrm{Ti}(\mathrm{Zr}),{ }^{[13]} \mathrm{Pt},{ }^{[14]} \mathrm{Rh},{ }^{[15]} \mathrm{Co},{ }^{[16]} \mathrm{Ir}^{[17]}$ and $\mathrm{Ru}^{[18]}$ can be used as well. Scheme $6^{[19]}$ illustrates an interesting example wherein a $\mathrm{Ru}$ complex is used as a catalyst to give a seven-membered ring compound $\mathbf{1 4}$.

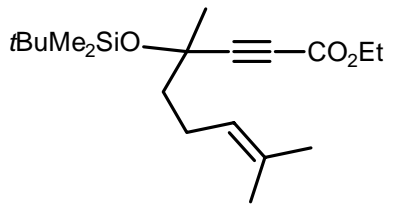

13

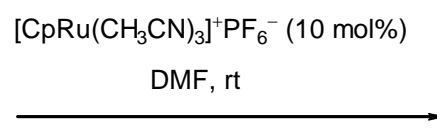

$67 \%$

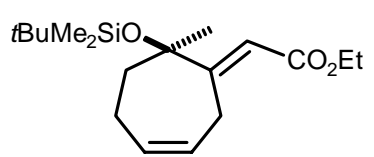

14

Scheme 6. 
Despite the diversity of the metals, which are capable of activating such cycloisomerizations, there are only few general mechanisms via which these metals can induce this cycloisomerization. ${ }^{[20]}$

\section{Heck Reaction}

The Heck reaction is another spectacular application for transition metals, specifically for palladium-catalyzed processes, whereby arylation and alkenylation of a vinylic halide or triflate can take place. During the last two decades, the Heck reaction has become one of the most widely used reactions in organic synthesis. ${ }^{[21]}$

Scheme 7 illustrates general proposed mechanism for the Heck reaction that suggests formation of a neutral coordinatively unsaturated 14-electron palladium(0) species which is considered the catalytically active complex. ${ }^{[21]}$ However, studies by Amatore assume that the Heck reaction proceeds via anionic species. ${ }^{[22]}$ 


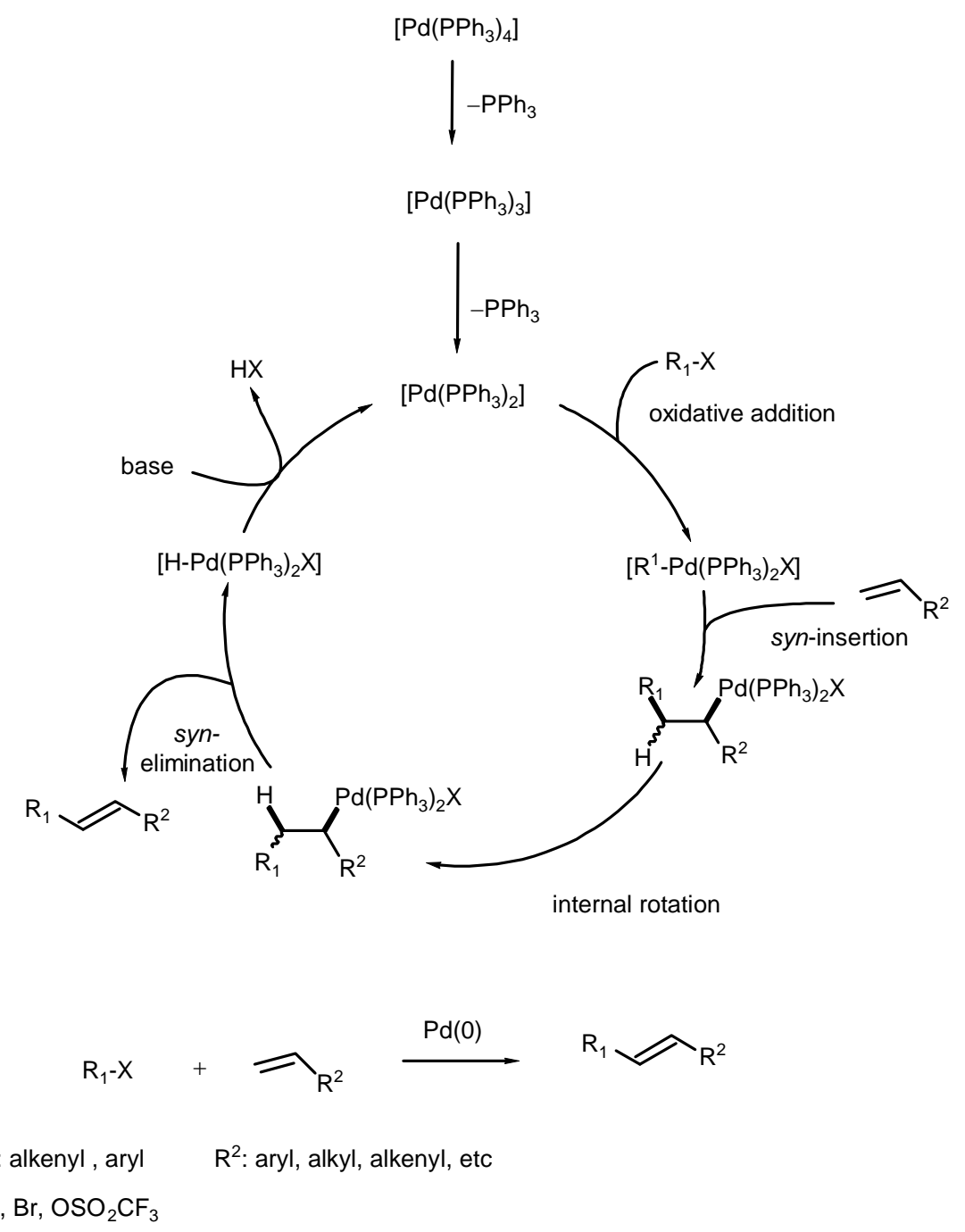

Scheme 7.

In a close analogy to the cycloisomerization reaction, the Heck reaction can be used to construct polycyclic systems in one-pot reactions. Thus, when the 2-bromo-1,6-diene is treated under standard Heck reaction conditions (palladium-acetate (3\%), triphenyl phosphine (8\%), silver carbonate (1.2 equiv), acetonitrile, $90 \mathrm{C}$ ), the cyclic 1,3-diene 16 will evolve which upon treating with a dienophile gives 17, (Scheme 8.). ${ }^{[23]}$ 


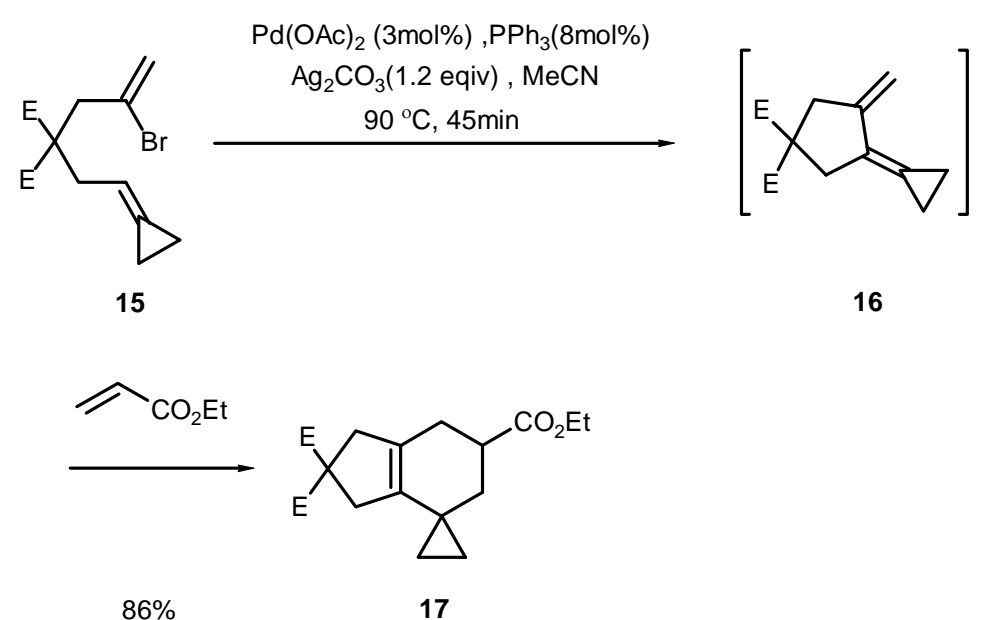

Scheme 8. $\mathrm{E}=\mathrm{CO}_{2} \mathrm{CH}_{3}$.

In contrast to palladium-catalyzed cycloisomerizations, the formation of six-membered rings and the subsequent reactions can be achieved more efficiently. (Scheme 9.). ${ }^{\text {[23] }}$

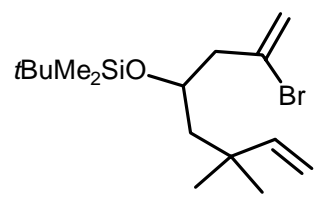

18

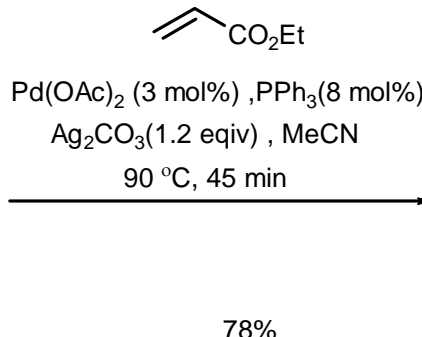

$78 \%$

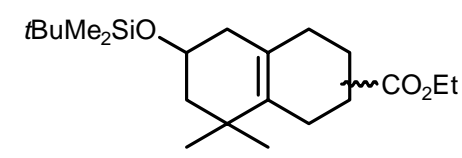

19

Scheme 9.

The Heck reaction was widely used in the synthesis of various natural products compounds. $^{[24]}$

\section{Cascade Reactions}

Cascade reactions can be described as sequential reactions with several steps of the same mechanistic type but with a changing substrate ${ }^{[25]}$ or sequential reactions with several steps of two or more different reaction type. ${ }^{[26]}$ The subtlest example of this type of the reactions is the one whereby the living cells are synthesizing steroids from Squalene 20 via a series of regio- and stereospecific cationic reactions and rearrangements, (Scheme 10). ${ }^{[27]}$ Once again we find God's creation in nature is overwhelmingly far ahead of us. 

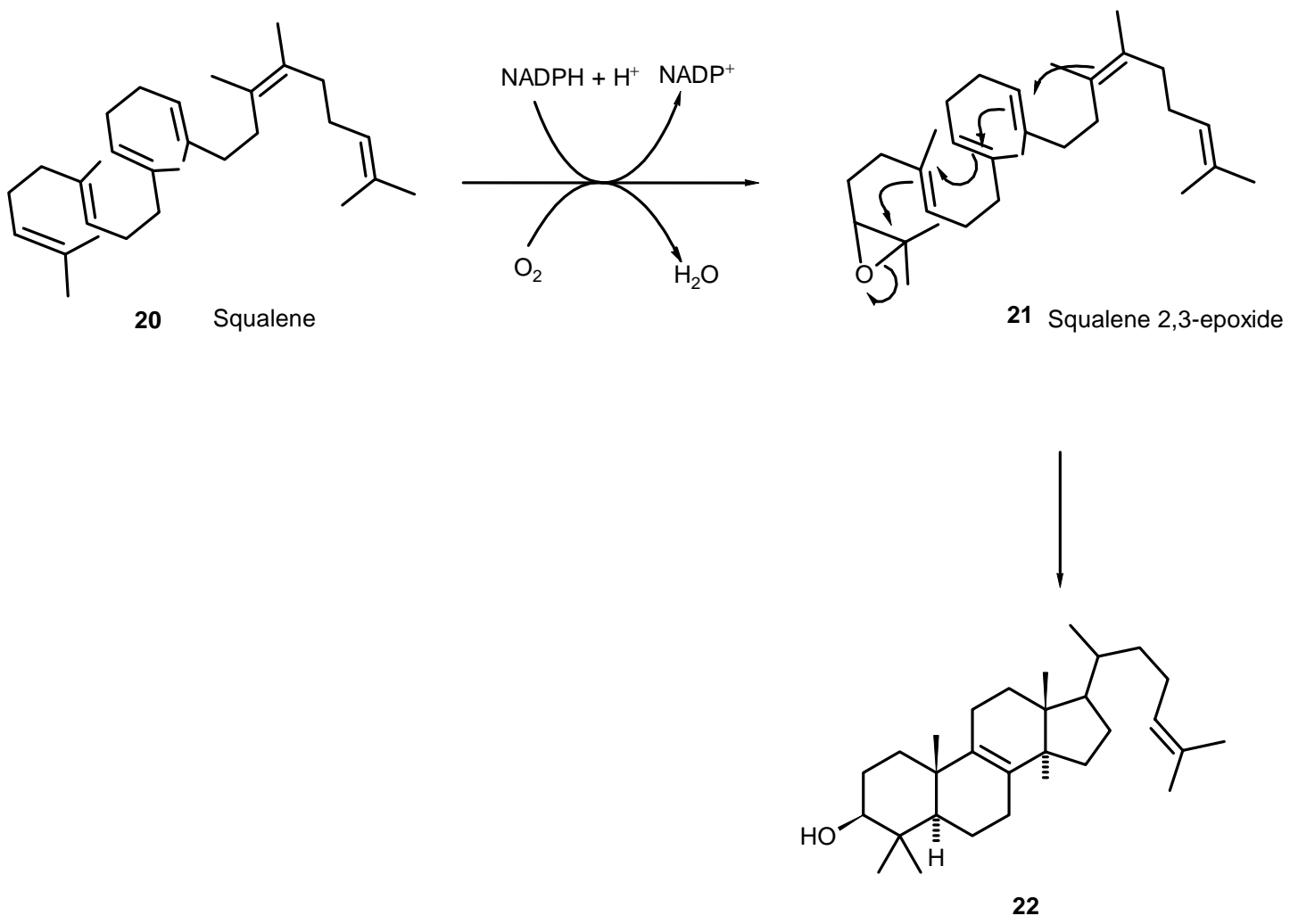

Scheme 10.

The previous two sections demonstrate two examples of cascade reactions wherein palladium catalyzed cycloisomerization or Heck reaction was followed by either an inter or an intramolecular Diels-Alder reaction.

Furthermore, when 2-halo-1,6-enynes, for example 23, are used, the resulting intermediates(eg. 24) will have the potential to undergo a further carbometallation to afford trienes $\mathbf{2 5}$ which by $6 \pi$-electrocyclization give tricyclic systems as $\mathbf{2 6}$, (Scheme 11.). ${ }^{[28]}$ 


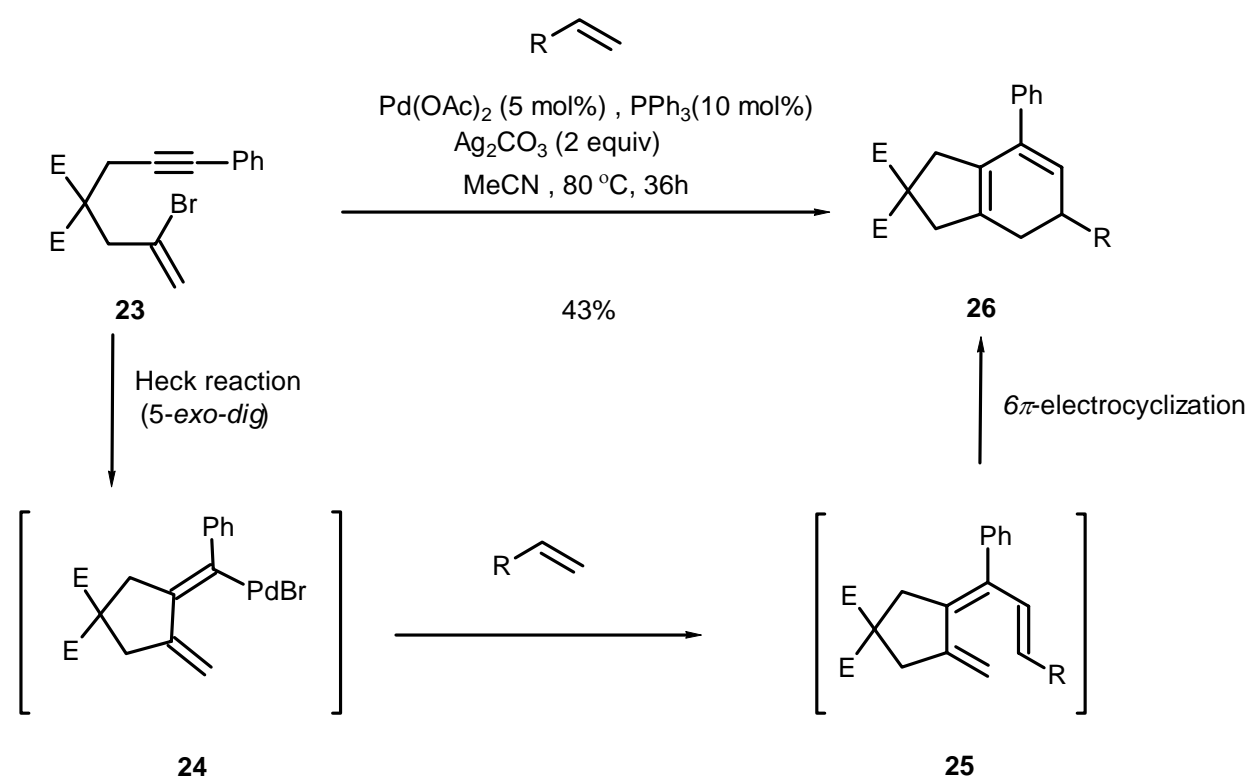

Scheme 11. $\mathrm{E}=\mathrm{CO}_{2} \mathrm{Et}, \mathrm{R}=\mathrm{OEt}$

This type of cascade reaction can be extended in an intramolecular fashion to construct complicated polycyclic systems in a single step. The feasibility of such processes stems from the low reactivity of the vinylmetal intermediate towards $\beta$-hydrogen elimination. ${ }^{[29]}$ Scheme 12 illustrates one example of this process. ${ }^{[30]}$ 


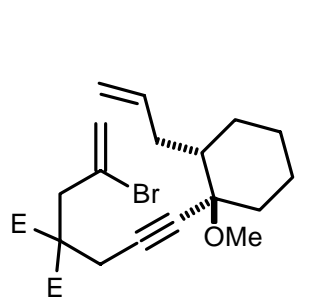

27

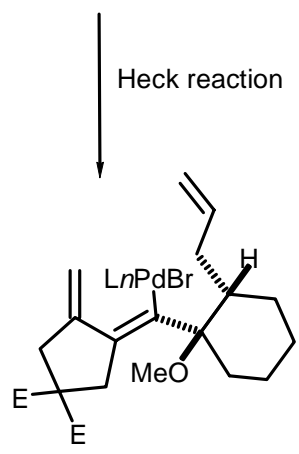

28
$\mathrm{Pd}(\mathrm{OAc})_{2}$ (3 mol\%), $\mathrm{PPh}_{3}(6 \mathrm{~mol} \%)$ $\mathrm{Ag}_{2} \mathrm{CO}_{3}$ (2 equiv) $\mathrm{MeCN}, 80^{\circ} \mathrm{C}, 3 \mathrm{~h}$

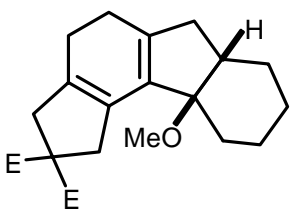

$48 \%$

30

$6 \pi$-electrocyclization<smiles>C=C1CC(F)(F)C/C1=C1\C(=C)C[C@@H]2CCCC[C@]12OC</smiles>

29

Scheme 12. $\mathrm{E}=\mathrm{CO}_{2} \mathrm{Et}$.

Negishi et al used such cascade reactions, triggered by Heck reaction, to construct steroid skeletons in an elegant way, (Scheme 13.). ${ }^{\text {[31] }}$

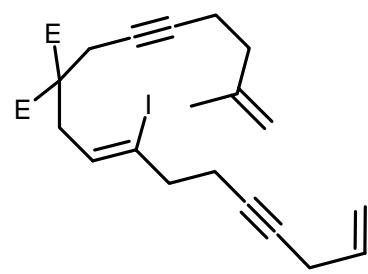

30

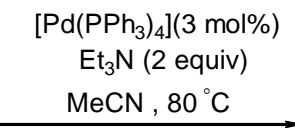

$76 \%$<smiles>C=C1CC2=C3CCC4=CCC(F)(F)CC4=C3CCC2(C)C1</smiles>

31

Scheme 13.

Similar cascade reactions can be initiated by palladium cycloismerization reaction. ${ }^{\text {[2] }}$ Constructing polycyclic systems with different ring sizes by using cascade reactions of the bromodienyne precursors 33a was explored. ${ }^{[33]}$ Cascade reactions which might lead to three fused six-membered rings, using bromoendiyne systems $\mathbf{3 3 b}$, were not thoroughly investigated. 


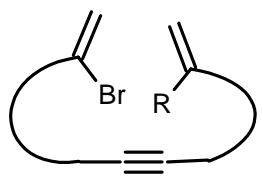

33 a

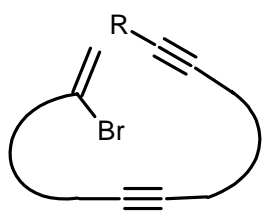

$33 \mathrm{~b}$

A recent study by Schweizer et al showed that the outcome of such precursors depends on the substitution at the terminal triple bond to give either aromatic or fulvene systems. ${ }^{[34]}$

Therefore this study is aiming at:

- Synthesis of some bromoendiyne precursors which might lead to the formation of three fused six-membered ring systems.

- Exploring the feasibility of their palladium catalyzed cyclizations.

- Studying the effect of the geminal substitution at the tether linking the vinylbromide moiety and the internal triple bond on the course of the reaction.

- Studying the effect of the substitution at the terminal alkyne.

- Trying to propose mechanisms to explain the outcomes of these cyclizations. 


\section{B. Main Part}

1. Palladium-catalyzed oligocyclization of 2-bromo-14-phenyl-tetradec-1-ene-7,13dynes

\subsection{Prologue}

The Palladium-catalyzed oligocyclization of 2-bromo-12-phenyldodeca-1,11-diene-6-yne to afford a tricyclic system with two five-membered rings fused to a six-membered central core was reported (Scheme 14.). ${ }^{\text {[35] }}$

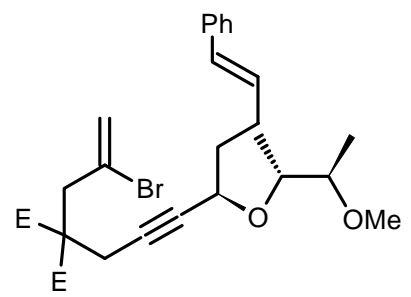

34

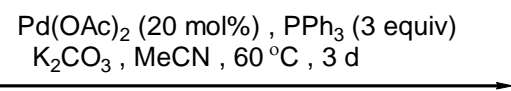

$67 \%$

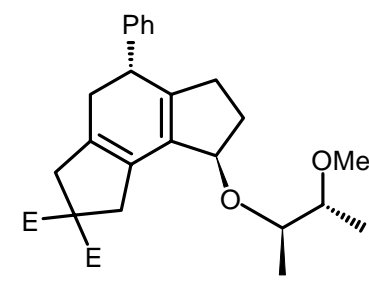

35

Scheme 14.

Although there are several mechanistic routes via which such cascade can take place, the fact that only one stereo and regio isomer was formed suggests that the cascade proceeds via a two-fold intramolecular Heck reaction followed by a disrotatory $6 \pi$ electrocyclization after $\beta$-hydride elimination, (Scheme 15 , route C), 


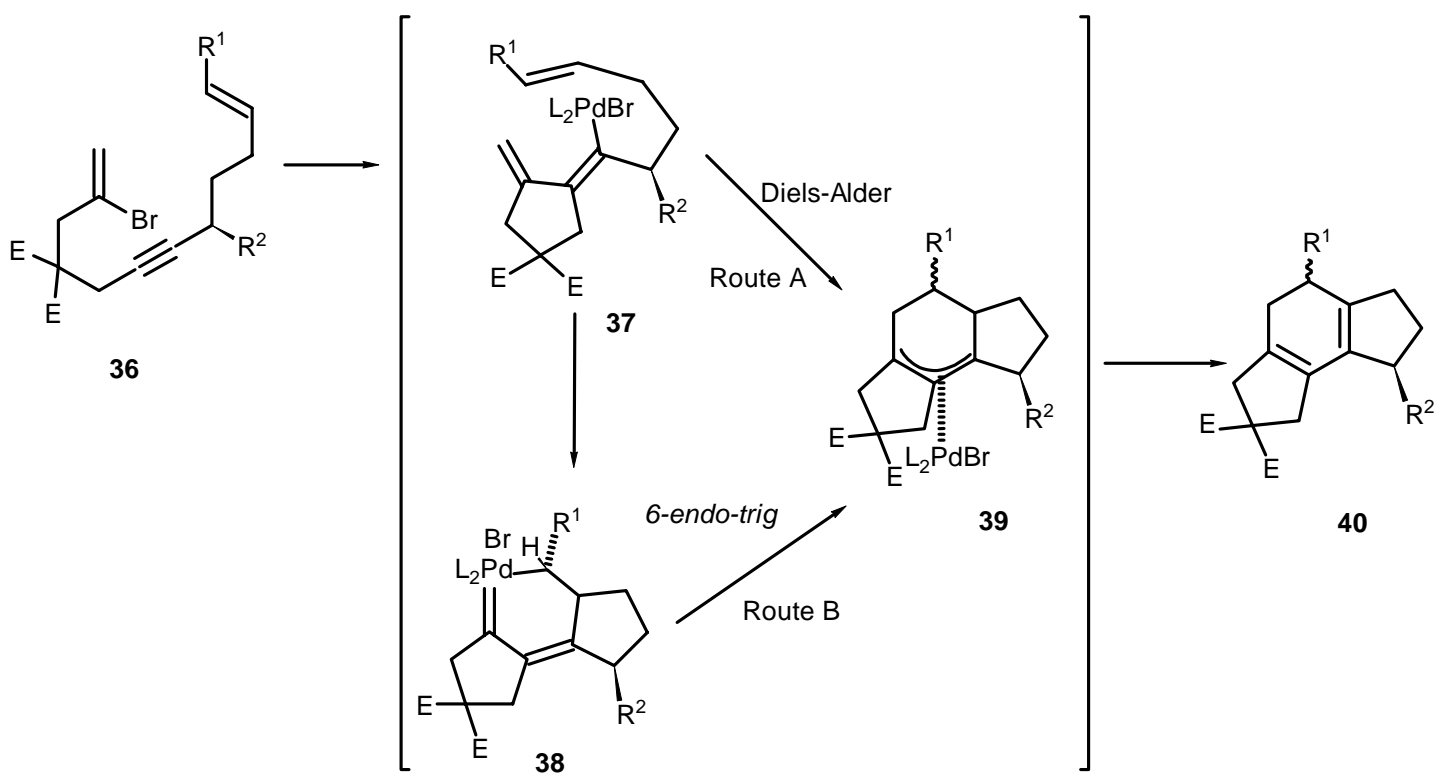

Route C $\mid \beta$-Hydrogen elimination

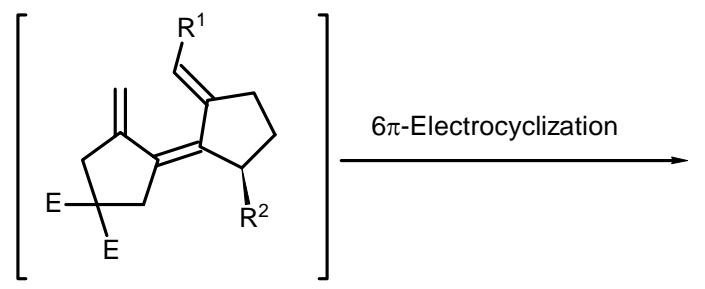

41

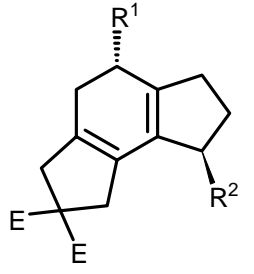

42

Scheme 15. $\mathrm{R}^{1}=\mathrm{H}, \mathrm{OMe}, \mathrm{R}^{2}=\mathrm{Ph}, \mathrm{CO}_{2} \mathrm{Me}, \mathrm{E}=\mathrm{CO}_{2} \mathrm{Et}$

However, when changing the substituents or the substituent pattern at the nonbrominated double bond, the cascade proceeds through one of the other two routes. This means that the pathway which the cascade will adapt depends on the substituents and the substituent pattern of the non-brominated alkene.

Trying to explore the scope of the cascade using different vinyl bromide systems which might lead to more complicated polycyclic systems, resulted in the same pattern of the cyclisation, (Scheme 16.). ${ }^{[30]}$ 
<smiles>COC(C#CCC(C)(F)C1CCCC=C1Br)CC/C=C/c1ccccc1</smiles>

43

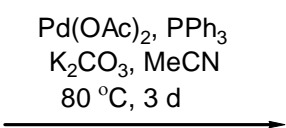
$80{ }^{\circ} \mathrm{C}, 3 \mathrm{~d}$

Scheme 16. $\mathrm{E}=\mathrm{CO}_{2} \mathrm{Et}$.

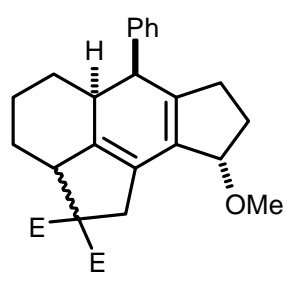

$44 \quad(30 \%)$<smiles></smiles>

45

Furthermore, when the cascade was initiated by hydropalladation instead of Heck reaction, similar results were obtained (Scheme 17). ${ }^{\text {[32] }}$

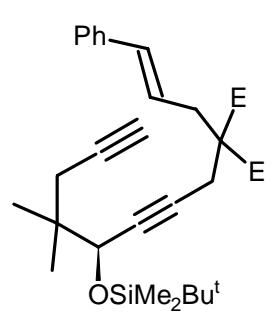

46

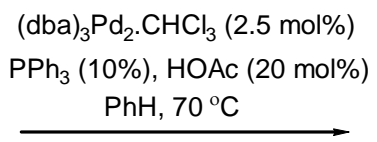

$69 \%$

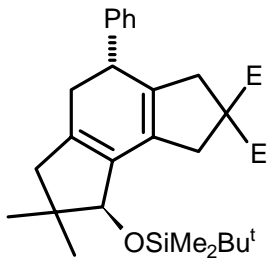

47

Scheme 17. $\mathrm{E}=\mathrm{CO}_{2} \mathrm{Et}$.

When the double bond bearing the phenyl moiety is replaced with a triple bond, the possibility for $\beta$-hydrogen elimination and tandem disrotatory $6 \pi$-electrocyclization or for Diels-Alder reactions (routes A\&C, Scheme 15) will be eliminated.

It is, therefore, of interest to examine the feasibility of the cascade reactions when the phenyl substituted alkene is replaced by phenyl substituted alkyne and to explore the scope of the cascade in constructing new polycyclic systems bearing three fused sixmembered rings. Thus, the synthesis and palladium-catalyzed oligocyclisation of precursors such as $\mathbf{4 8}$ and $\mathbf{4 9}$ will be investigated 


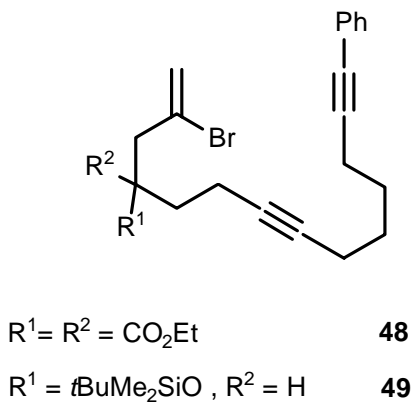

Fig 1

\subsection{Synthesis of phenyl substituted precursors}

The synthesis of $\mathbf{4 8}$ can be achieved by a series of carbon-carbon coupling steps, (Scheme18.). Consequently, treating phenyl acetylene with n-butyl lithium and further coupling with 1,4-dibromobutane, following a general protocol described by J.K. Crandall et al, ${ }^{[36]}$ gives 6-bromo-1-phenyl-1-hexyne (51) in a 77\% yield . The reaction is highly sensitive to the quantity of $n$-butyl lithium used , since excessive use of n-butyl lithium would lead to the undesired free radical cyclization of the product and hence lowering the yield. ${ }^{[37]}$ The produced compound 51 is then coupled, at $-78{ }^{\circ} \mathrm{C}$, with lithiated 2-(3-butynyloxy)tetrahydro-2H-pyran 52, prepared from PPTS-catalyzed reaction of 2,3-dihydropyran with 3-butyn-1-ol which was obtained from acetylene and ethylene oxide, ${ }^{[38]}$ in THF and HMPA to give 53 in a $48 \%$ yield. Subsequently, the OTHP group of 53 is converted into its corresponding bromide ${ }^{[39]} 54$ which is then attached to sodium malonate, generated by treating diethyl malonate with sodium hydride, to furnish 55 in a 63\% yield. The produced diethyl 2-(10'-phenyl-3',9'decadiynyl)malonate $\mathbf{5 5}$ is then treated with sodium hydride in DME and coupled with 2,3-dibromopropene to afford the target precursor 48 in a $44 \%$ yield. As the last step is a solvent sensitive $\mathrm{S}_{\mathrm{N}} 2$ nucleophilic substitution, ${ }^{[40]}$ it will be shown latter that altering the solvent polarity will highly affect the yield. 


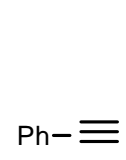

50

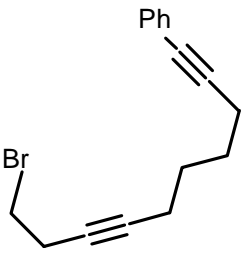

54 $65 \% \quad \begin{gathered}\mathrm{NaH}, \mathrm{DMF} \\ \text { Diethylmalonate } \\ 36 \mathrm{~h}\end{gathered}$

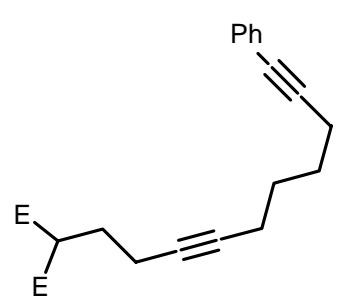

55

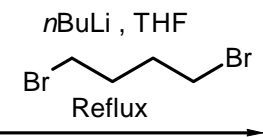

$75 \%$

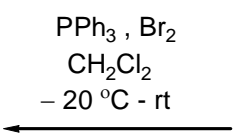

$75 \%$

$\mathrm{NaH}, \mathrm{DME}$ 2,3-Dibromopropene $24 \mathrm{~h}$

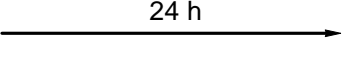

$48 \%$

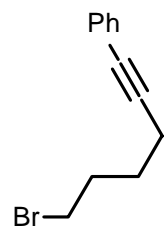

51

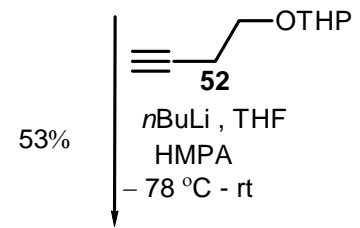

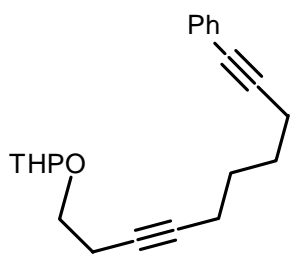

53

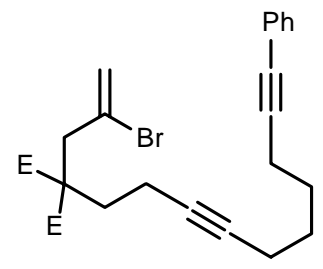

48

Scheme 18. $\mathrm{E}=\mathrm{CO}_{2} \mathrm{Et}$.

The retro synthesis of $\mathbf{4 9}$ reveals two approaches for preparing it, (Scheme 19.). The first step in both approaches involves disconnecting the bond between the carbon bearing the silyloxy group and the allyl bromide moiety. The second step in the first approach involves breaking the $\mathrm{C}-\mathrm{C}$ bond which links the internal acetylene with 1-phenyl-1hexyne moiety to afford the synthons 51 And 64, (route B). However, the second step in the second approach involves disconnecting the phenyl moiety followed by breaking the 
C-C bond from the left side of the internal acetylene moiety to afford $\mathbf{6 0}$ And $\mathbf{6 1}$, (route A).

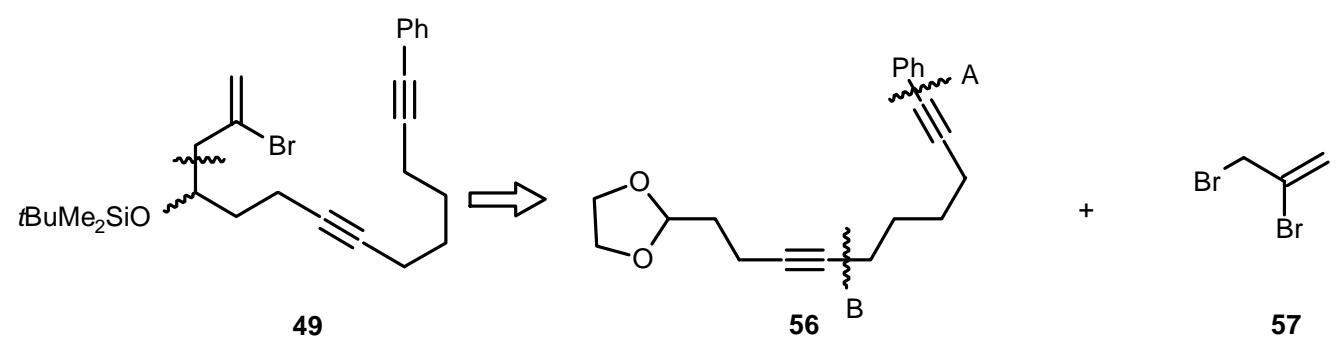

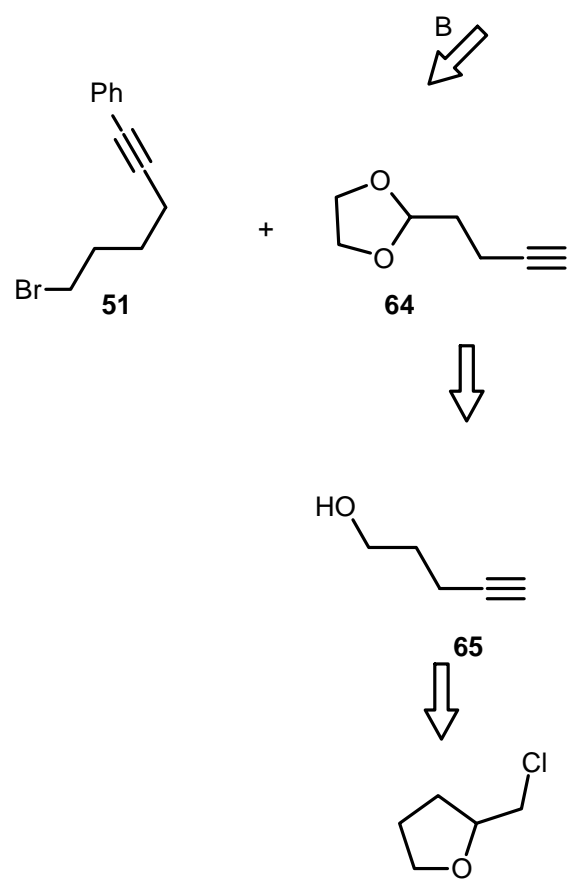

66

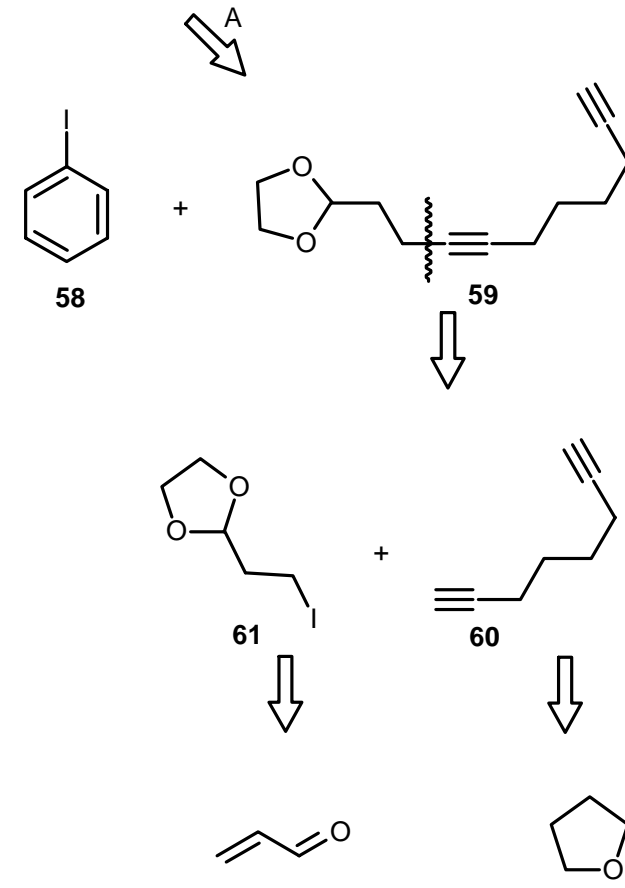

62

Scheme 19.

Compound $\mathbf{6 1}$ can be synthesised from acroleine $\mathbf{6 6}$ by either one ${ }^{[41]}$ or two step synthesis (Scheme 20.). ${ }^{[42]}$ 1,7-octadiyne $\mathbf{6 0}$ can be obtained from tetrahydrofurane as shown in Scheme 21. 


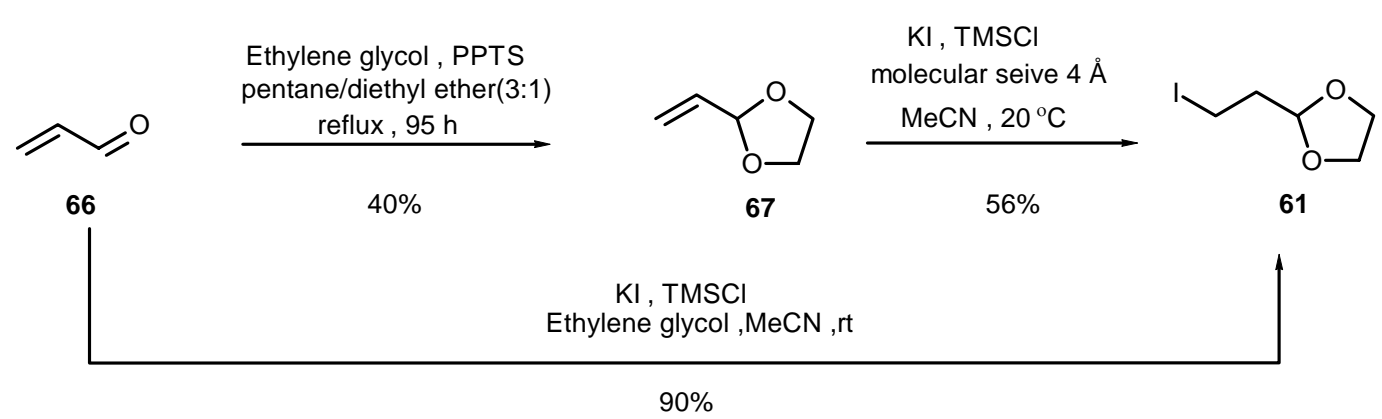

Scheme 20.

Scheme 21 illustrates the synthesis of $\mathbf{4 9}$ using the two approaches. Thus Swern oxidation of pentyn-1-ol, ${ }^{[43]}$ prepared by treating of chloromethyltetrahydrofurane with sodium amide in liquid ammonia, ${ }^{[44]}$ gives the unstable aldehyde 69 in a $90 \%$ yield which is then refluxed with ethylene glycol and PPTS in benzene to give the corresponding acetal 64 . Treating the acetal with $n$-butyl lithium and then coupling with 6-bromo-1-phenyl-1hexyne (51) produces 56 in a 60\% yield. Alternatively, the acetal 56 can be obtained by rout $\mathrm{B}$. Thus treating tetrahydrofurane with phosphorous pentoxide and potassium iodide affords 1 ,4-diiodobutane $\mathbf{( 6 8})^{[45]}$ which is then treated with the acetylenic anion in liquid ammonia to give 1,7 -octadiyne $(\mathbf{6 0})^{[46]}$ in a $73 \%$ yield. $\mathbf{6 0}$ is then treated with n-butyl lithium and coupled with 2-(1,3-dioxolan-2-yl)ethyl iodide 61 to produce 59 in a $46 \%$ yield. The low yield might be attributed to the chemoselectivity problem of the 1,7octadyne and the subsequent side reactions that might take place. Nonetheless, about $40 \%$ of 1,7-octadyne can be recovered. Despite the possible side reactions, using Sonogashira ${ }^{[3]}$ coupling to attach the phenyl group to the terminal alkyne of $\mathbf{5 9}$ succeeds in a reasonable yield. Consequently, when $\mathbf{5 9}$ is treated with iodobenzene (58) in the presence of (0.5 mol \%) $\mathrm{PdCl}_{2}\left(\mathrm{PPh}_{3}\right)_{2}$ and (2 mol \%) CuI in triethylamine, it affords 56 in a $63 \%$ yield. The produced phenyl-substituted actal $\mathbf{5 6}$, from both routes A \& B, is then coupled with 2,3-dibromopropene in the presence of powdered tin, by modifying the procedure described by Otera et al, ${ }^{[4]}$ to afford the alcohol 70. Because the reaction is time-dependant, stirring the reaction for longer periods, 4-5 days, will improve the yield significantly. The alcohol is then protected by tert-butyldimethylsilyl chloride using imidazole in DMF to give the target precursor $\mathbf{4 9}$ in an 82\% yield. 


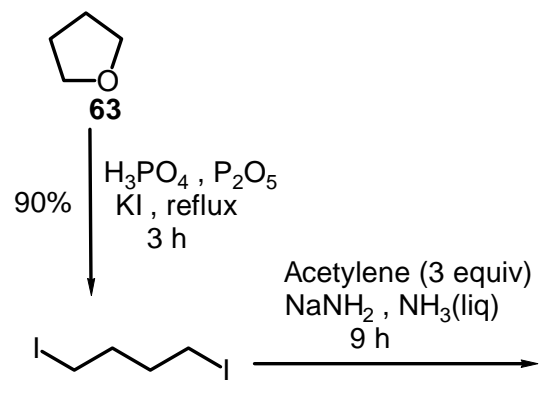

68

$74 \%$

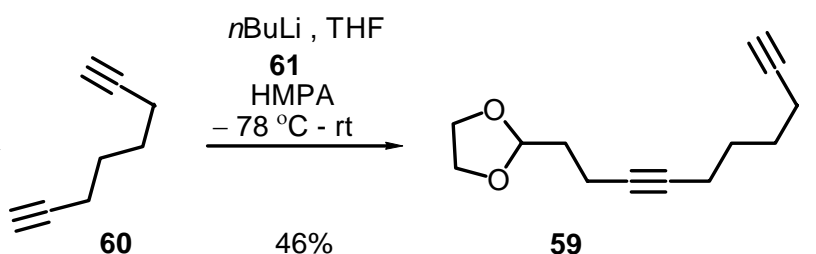

Route A
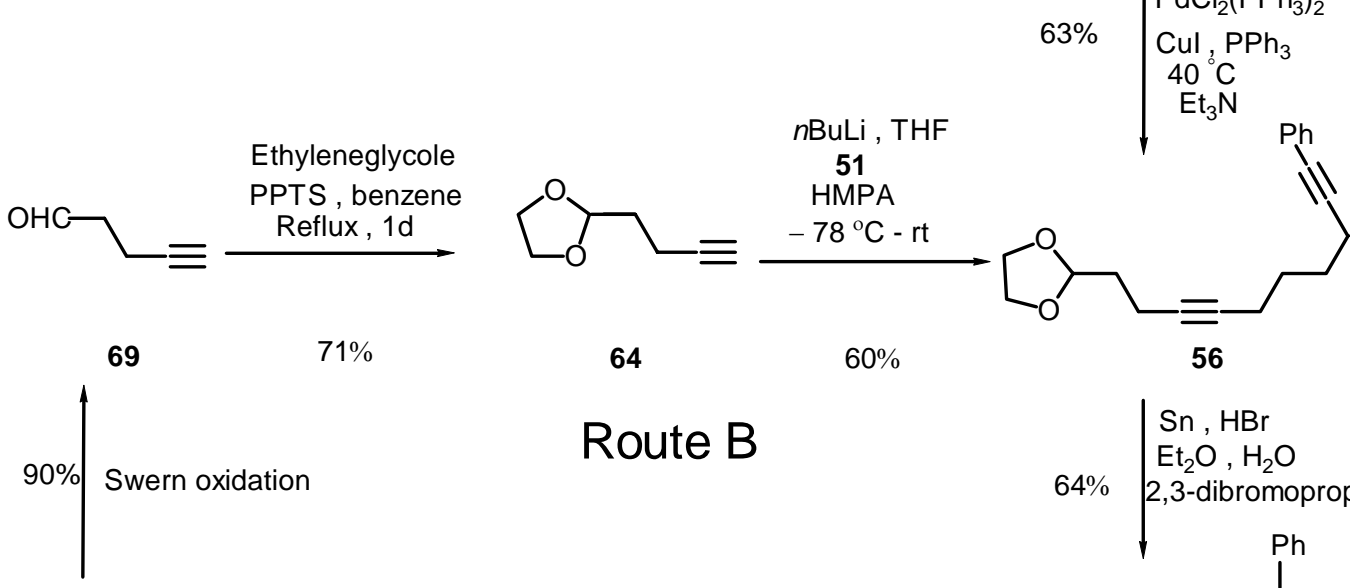

Route B

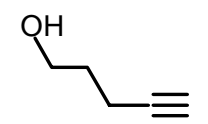

65

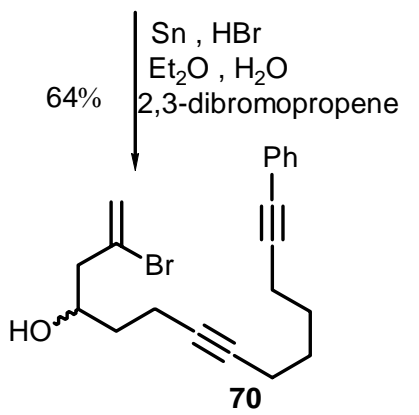

$85 \% \mid \begin{gathered}\text { tBuMe } \mathrm{BiCl}_{2}, \text { imidazole } \\ \mathrm{DMF} \\ 35{ }^{\circ} \mathrm{C}, 24 \mathrm{~h}\end{gathered}$<smiles>C=C(Br)C[C@@H](CCC#CCCCCC#CPc1ccccc1)O[SiH3]</smiles>

Scheme 21.

It is noteworthy that trying to synthesize $\mathbf{4 9}$ by direct coupling of $\mathbf{7 1}{ }^{[48]}$ with 6-bromo-1phenyl-1-hexyne 51 was unsuccessful, (Scheme 22.). 

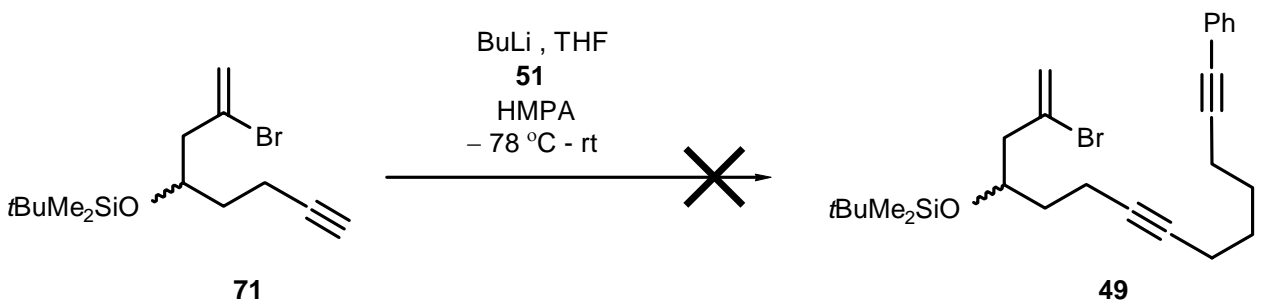

71

49

Scheme 22.

\subsection{Palladium-catalyzed oligocycliztions of phenyl substited precursors}

When 48 had been heated at $80{ }^{\circ} \mathrm{C}$ in $\mathrm{DMF}$ in the presence of palladium acetate (10 mol\%), triphenyl phosphine (25 mol\%) and sodium formate, compound 73 was formed in a 40\% yield, (Scheme 23.). Apparently, a palladium-catalyzed oligocyclization had taken place to give $\mathbf{7 3}$. The structure of $\mathbf{7 3}$ was established by one- and two-dimensional NMR techniques. Mass spectroscopy proved the loss of $\mathrm{HBr}$ while the appearance of new six olefinic signals in ${ }^{13} \mathrm{C}$-NMR spectrum indicates the formation of a tricyclic system with a two tetrasubstituted double bonds and one trisubstituted double bond. The presence of new olefinic singlet at $6.90 \mathrm{ppm}$ in the ${ }^{1} \mathrm{H}$-NMR spectrum confirms this conclusion. $\mathrm{H} / \mathrm{H}$ COSY and gHSQC are in agreement with the proposed structure.

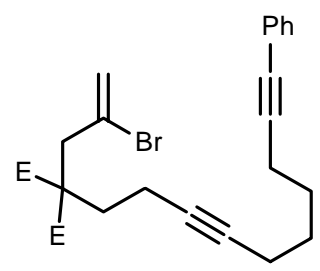

48

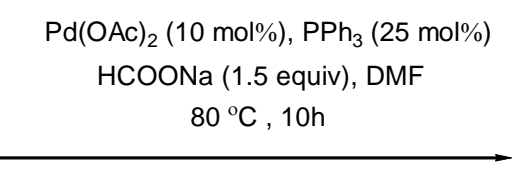

$40 \%$

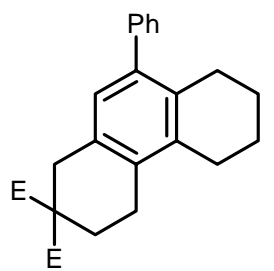

73

Scheme 23. $\mathrm{E}=\mathrm{CO}_{2} \mathrm{Et}$

Subjecting 49 to the standard Heck reaction conditions, palladium acetate, triphenyl phosphine and potassium carbonate in acetonitrile, had failed to induce the desired cascade and only the starting material was recovered. Nevertheless, when $\mathbf{4 9}$ had been heated at $80{ }^{\circ} \mathrm{C}$ in DMF and in the presence of palladium acetate (10 mol\%), triphenyl phosphine (25 mol\%) and sodium formate, compound 74 was formed in a 15\% yield, (Scheme 24.). Compound $\mathbf{7 4}$ was characterized by one- and two-dimensional NMR and it showed nearly similar spectral patterns as those for $\mathbf{7 3}$. 


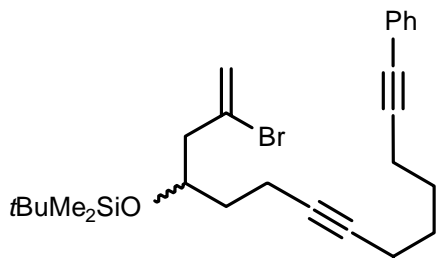

49

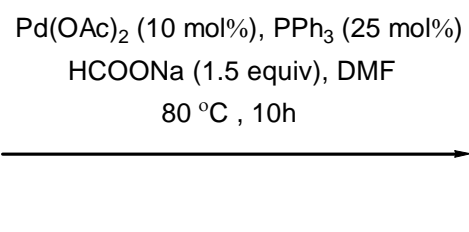

$18 \%$

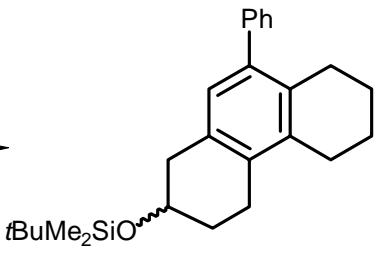

74

Scheme 24.

It is clear from schemes 23 and 24 that the presence of the malonate group has an influence on the yield of the cascade but not the outcome of the cascade. 


\section{Palladium-catalyzed oligocyclization of 2-bromo-14-tert-butyldimethylsilyl tetradec-1-ene-7,13-dynes}

\subsection{Prologue}

Palladium-catalyzed oligocyclization of tert-butyldimethylsilyl substituted of 2-bromotetradec-1-ene7,13-diyne such as 77 was reported,( Scheme 25.) ${ }^{[34]}$

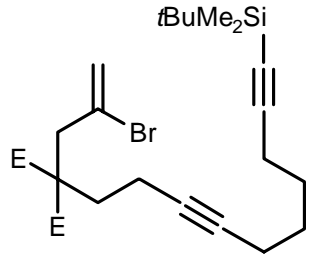

77

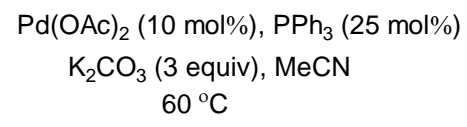

$79 \%$<smiles>CC(C)(C)[SiH2]c1cc2c(c3c1CCC(F)(F)C3)CCCC2</smiles>

78

Scheme 25.

Nevertheless, in the last section it was observed that the geminal substitution at the tether which links the vinyl bromide moiety with internal alkyne of such precursors has an influence on the yield of the cascade. Thus, when the malonate was replaced by the bulky tert-butyldimethylsilyloxy group, the cascade's yield sharply decreased. The reason behind this is not clear yet. It might be attributed to stericaly factors imposed by the malonate group or any similar group on the carbon chain that make it into more suitable conformation for such cyclizations or to instability of the final outcomes of the cascade. It is, therefore, of interest to investigate the feasibility of such cyclizations when the malonate is replaced with tert-butyldimethylsilyloxy group such as $\mathbf{8 0}$ or with substituents devoid steric hindrance such as $\mathbf{7 9}$ 


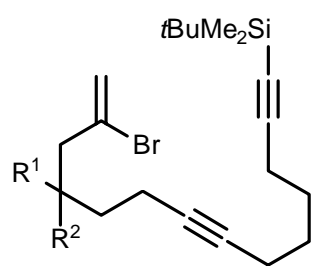

$$
\begin{array}{lll}
\mathrm{R}^{1}=\mathrm{H} & \mathrm{R}^{2}=\mathrm{H} & \mathbf{7 9} \\
\mathrm{R}^{1}=t \text { BuMe }_{2} \text { SiO } & \mathrm{R}^{2}=\mathrm{H} & \mathbf{8 0}
\end{array}
$$

Fig 2.

\subsection{Synthesis of tert-butyldimethylsilyl substituted precursors}

The retrosynthesis of $\mathbf{7 9}$ reveals two routes for preparing 79 (Scheme 26.). The first route starts with dehydrohalogenation of the vinyl bromide to afford a triyne system $\mathbf{8 1}$. Further fragmentation of the later by breaking the $\mathrm{C}-\mathrm{C}$ bond from the right side of the internal alkyne would produce $\mathbf{6 0}$ and $\mathbf{8 2}$ which can be easily prepared from 5-hexyn-1-ol 83. The second approach involves breaking the $\mathrm{C}-\mathrm{C}$ bond from the left side of the internal alkyne to afford $\mathbf{8 6}$ and $\mathbf{8 5}$ which can also be prepared from 5-hexyn-1-ol (83). 
<smiles>[CH]C(CCC#CCCCCC#C[AsH2])CC(=C)Br</smiles>

79

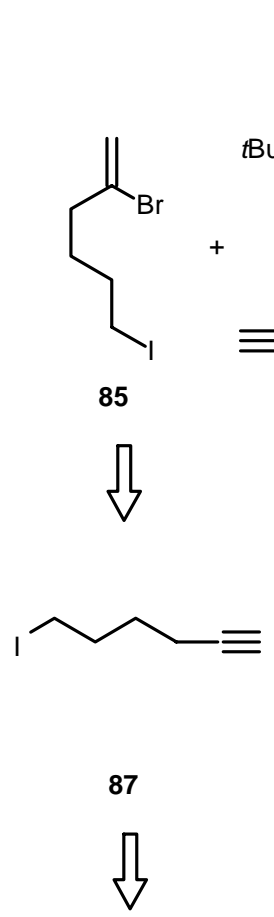

$y$

$\sqrt{3}$

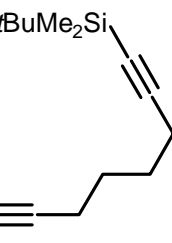

86

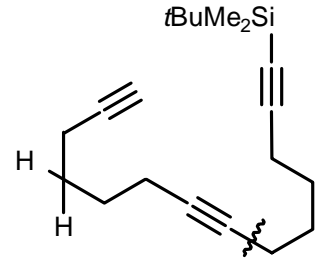

81<smiles>C1=CCC1</smiles>

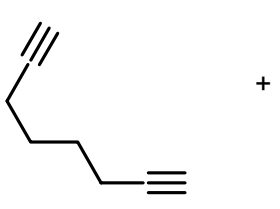

60

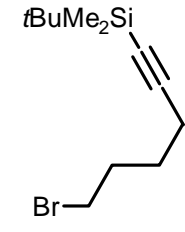

82

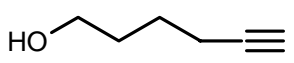

83
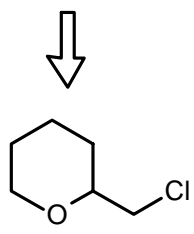

84

Scheme 26.

Before describeing the synthesis of $\mathbf{7 9}$, compound 85 can be prepared by converting 5hexyn-1-ol (83), which can be obtained from treating 2-chloromethyl-tetrahydro-2Hpyran (84) with sodium amide in liquid ammonia, ${ }^{[49]}$ into the corresponding iodide 87 and then hydrobromination the terminal alkyne with B-bromo-9- 
borabicyclo[3.3.1]nonane (9-bromo-9-BBN) (88), a protocol described by W.F.Baily et al. $^{[37]}$, (Scheme 27.).

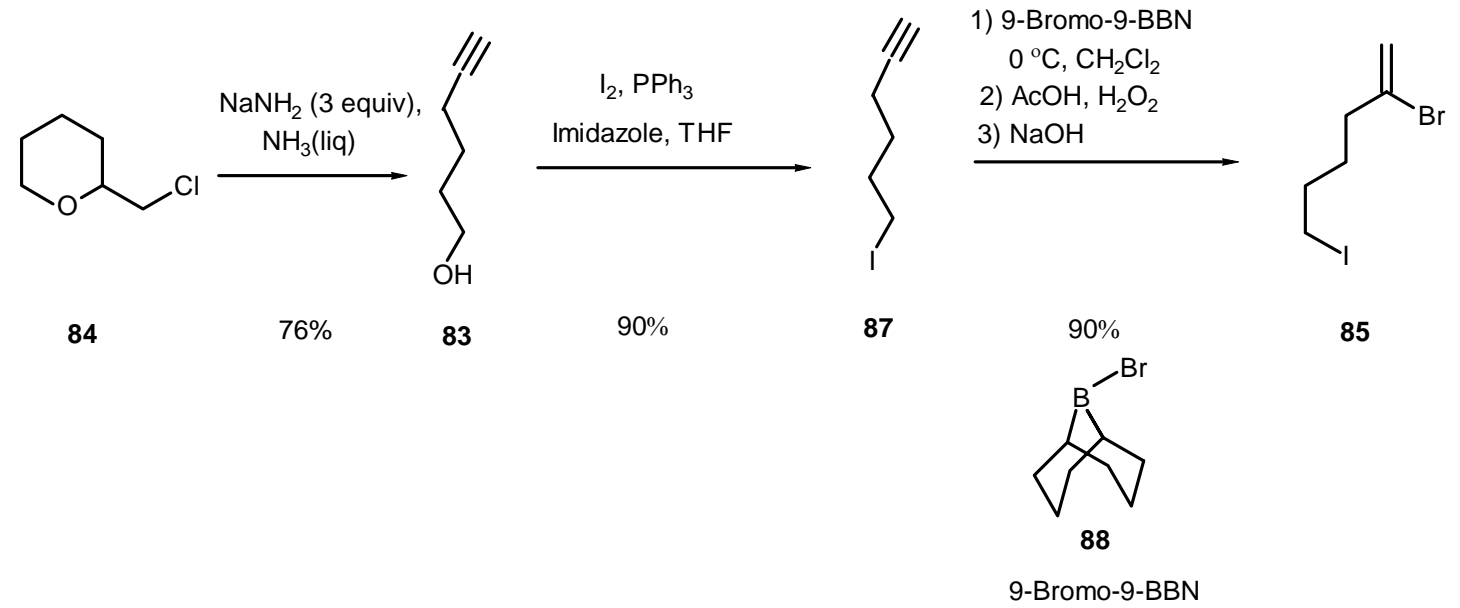

Scheme 27.

Compound 82 can also be synthesized from hexyn-1-ol (83) according to a described procedure. $^{[33]}$

Compound 79 can be synthesized by two routes, (Scheme 28.). In Route A, 1,7-octadyne (60) is treated with n-butyl lithium and HMPA in THF and coupled with 6-bromo-1-tertbutyldimethylsilyl hex-1-yn 82 to give the triyne system $\mathbf{8 1}$. Treatment the resulting triyne with 9-bromo-9-BBN 88 in dichloromethane and subsequent protonolysis gives the desired precursor 79 in a 20\% yield. Despite the high chemo-, regio- and stereoselectivity of the 9-bromo-9-BBN ${ }^{[50]}$ (the haloboration can take place only at the terminal mono substituted alkynes and not at the internal disubstituted alkynes) the yield of the last step is not very high. This is maybe due to the polymerization of $\mathbf{8 1}$ or side reactions that might take place. Because of the low yield of Route A, Route B becomes an alternative approach. In Route B, the lithiated 1,7-octadiyne is attached to tert-butyldimethylsilyl chloride $^{[51]}$ followed by coupling with 85 to give the precursor 79 in a $40 \%$ yield. Unfortunately Route B does not offer a good substitute for Route A this due to the low yield of its two steps. 


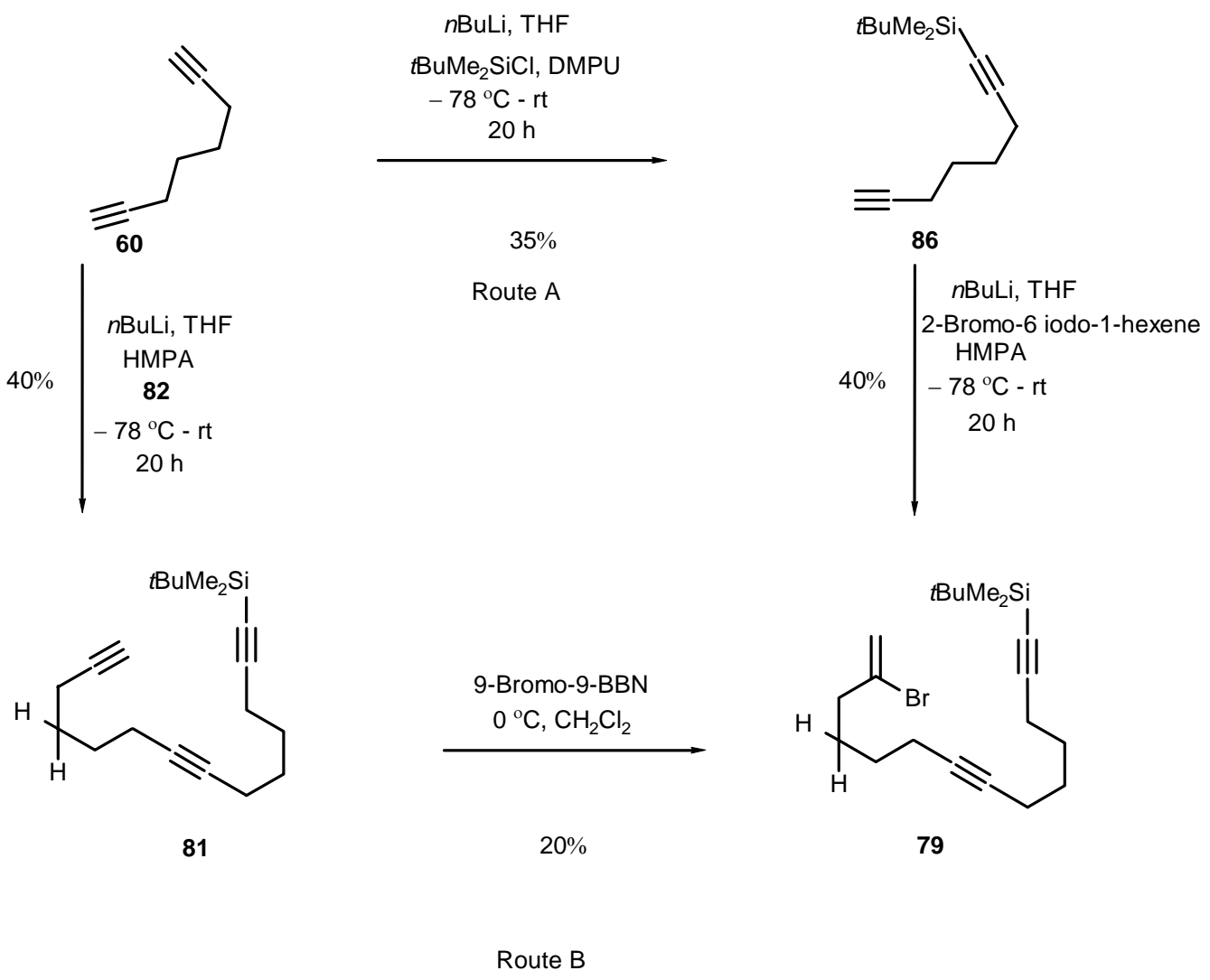

Scheme 28.

Compound 80 is prepared in a similar manner like 49. Thus compound 89 can be prepared following the same two routes for preparing 49, (Scheme 29.). In Route A, compound 89 is generated from linking the lithiated acetal 64 with 6-bromo-1-tertbutyldimethylsilyl hex-1-yn (82). However, in Route B, it is produced by alkylating the lithiated 1,7-octadiyne with $\mathbf{6 1}$ to produce 59, (Scheme 21, Route A), and Silylation of the terminal triple bond of the later with tert-butyldimethylsilyl chloride. Treatment $\mathbf{8 9}$ with 2,3-dibromopropene in the presence of tin powder produces the alcohol $\mathbf{9 0}$ which is then protected by tert-butyldimethylsilyl chloride to give $\mathbf{8 0}$. 


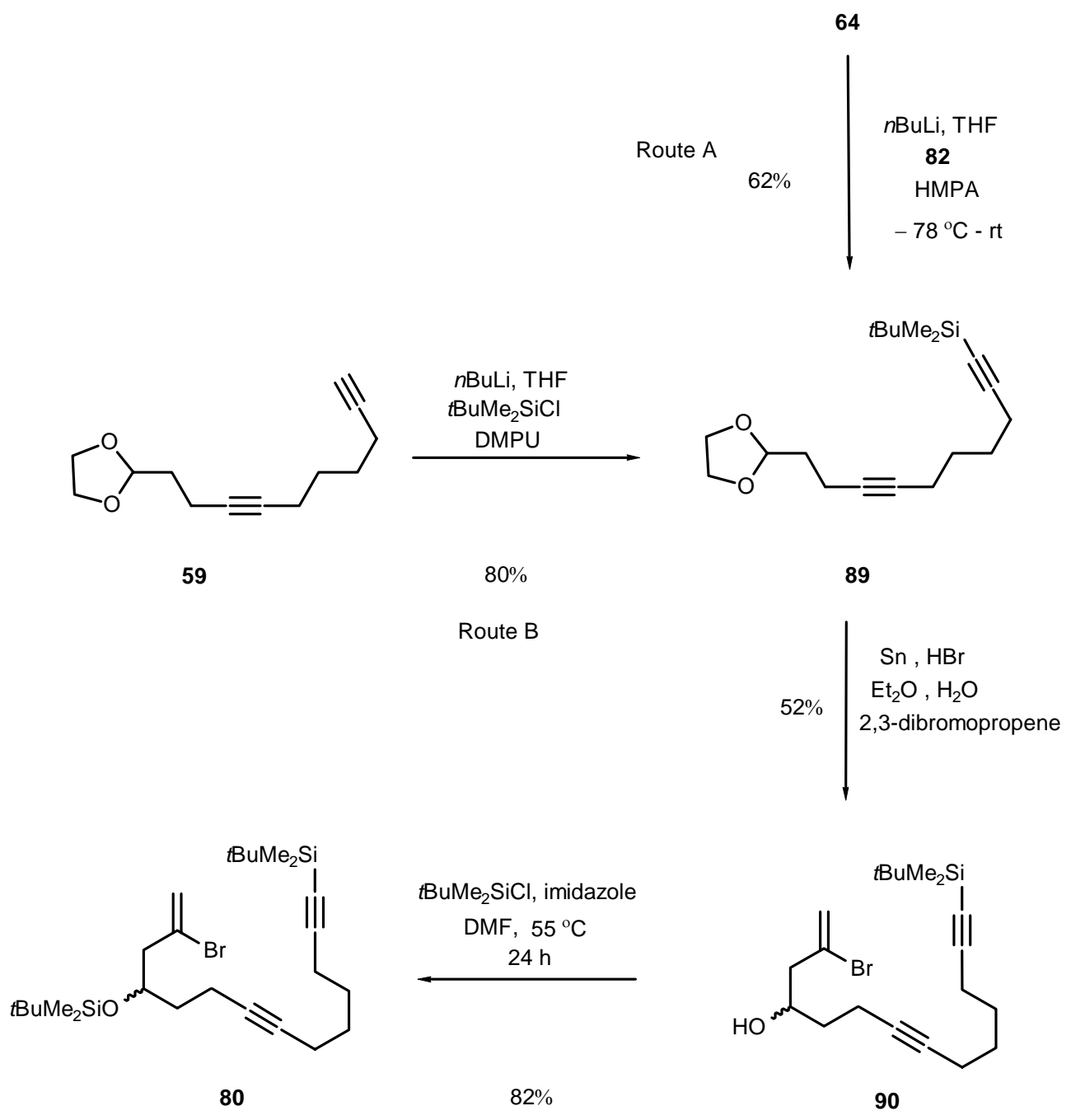

Scheme 29.

2.3. Palladium-catalyzed oligocyclizations of tert-butyldimethylsilyl substituted precursors

Table 1 shows different variations of conditions to cyclize 79. In most cases the starting material was recovered and the cyclization had not taken place. However, only when $\mathbf{7 9}$ had been treated at $80{ }^{\circ} \mathrm{C}$ with palladium acetate $(10 \mathrm{~mol} \%)$ and sodium formate in DMF, did the cyclization take place to afford the bisannelated benzene derivative 91, (Scheme 30.) 


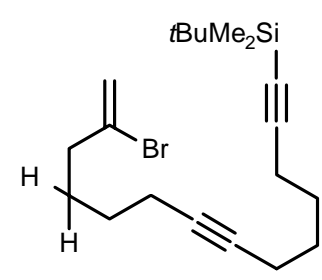

79

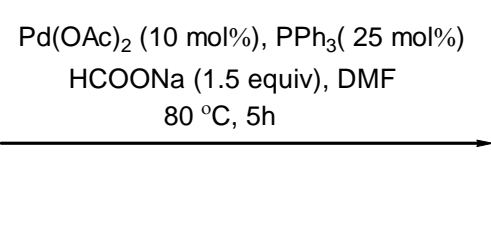

$20 \%$

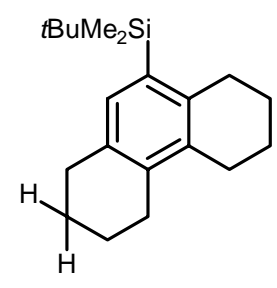

91

Scheme 30. (Conditions, see Table1)

Table 1

\begin{tabular}{clc}
\hline Entry & \multicolumn{1}{c}{ Reaction Conditions and Reagents } & Product \\
\hline 1 & $\mathrm{Pd}(\mathrm{OAc})_{2}, \mathrm{PPh}_{3}, \mathrm{~K}_{2} \mathrm{CO}_{3}, \mathrm{CH}_{3} \mathrm{CN}, 60{ }^{\circ} \mathrm{C}, 20 \mathrm{~h}$ & starting material \\
2 & $\mathrm{Pd}(\mathrm{OAc})_{2}, \mathrm{PPh}_{3}, \mathrm{Ag}_{2} \mathrm{CO}_{3}, \mathrm{THF}, 60{ }^{\circ} \mathrm{C}, 20 \mathrm{~h}$ & starting material \\
3 & $\mathrm{Pd}(\mathrm{OAc})_{2}, \mathrm{PPh}_{3}, \mathrm{Ag}_{2} \mathrm{CO}_{3}, \mathrm{DMF}, 80{ }^{\circ} \mathrm{C}, 20 \mathrm{~h}$ & starting material \\
4 & $\mathrm{Pd}(\mathrm{OAc})_{2}, \mathrm{PPh}_{3}, \mathrm{Et}_{3} \mathrm{~N}, \mathrm{DMF}, 80{ }^{\circ} \mathrm{C}, 20 \mathrm{~h}$ & starting material \\
5 & $\mathrm{Pd}(\mathrm{OAc})_{2}, \mathrm{PPh}_{3}, \mathrm{HCOONa}, \mathrm{DMF}, 80{ }^{\circ} \mathrm{C}, 20 \mathrm{~h}$ & $\mathbf{9 1}$ \\
\hline
\end{tabular}

Again the disappearance of the acetylenic carbon signals and the appearance of new six olefinic carbons in the ${ }^{13} \mathrm{C}-\mathrm{NMR}$ indicate the formation of three double bonds. Mass spectroscopy confirms the loss of $\mathrm{HBr}$ and the ${ }^{1} \mathrm{H}$-NMR shows the appearance of a new singlet at $7.05 \mathrm{ppm}$ which supports the formation of a tricyclic system with two tetrasubstituted double bonds and one trisubstituted double bond. $\mathrm{H} / \mathrm{H}$ COSY and gHSQC are in agreement with this conclusion.

Similarly, trying to subject precursor $\mathbf{8 0}$ to different reaction conditions, failed to induce the desired oligocyclization, (Table2). Nonetheless, the cyclization did take place when 80 had been treated at $80{ }^{\circ} \mathrm{C}$ with tetraethyl ammonium chloride, palladium acetate and sodium formate in DMF to give also an aromatic system 92, (Scheme 31.). 


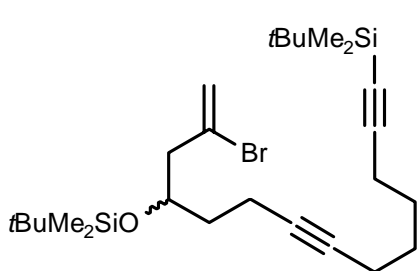

80

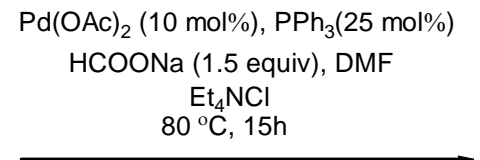

$\mathrm{Et}_{4} \mathrm{NCl}$
$80^{\circ} \mathrm{C}, 15 \mathrm{~h}$

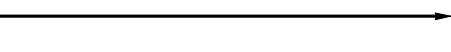

15\%

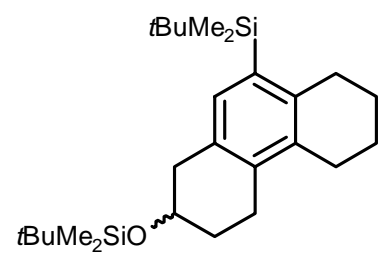

92

Scheme 31.

Table 2

\begin{tabular}{cll}
\hline Entry & \multicolumn{1}{c}{ Reaction Conditions and Reagents } & Product \\
\hline 1 & $\mathrm{Pd}(\mathrm{OAc})_{2}, \mathrm{PPh}_{3}, \mathrm{~K}_{2} \mathrm{CO}_{3}, \mathrm{CH}_{3} \mathrm{CN}, 60{ }^{\circ} \mathrm{C}, 20 \mathrm{~h}$ & starting material \\
2 & $\mathrm{Pd}(\mathrm{OAc})_{2}, \mathrm{PPh}_{3}, \mathrm{Ag}_{2} \mathrm{CO}_{3}, \mathrm{CH}_{3} \mathrm{CN}, 60{ }^{\circ} \mathrm{C}, 20 \mathrm{~h}$ & starting material \\
3 & $\mathrm{Pd}(\mathrm{OAc})_{2}, \mathrm{PPh}_{3}, \mathrm{Ag}_{2} \mathrm{CO}_{3}, \mathrm{DMF}, 80{ }^{\circ} \mathrm{C}, 20 \mathrm{~h}$ & starting material \\
4 & $\mathrm{Pd}(\mathrm{OAc})_{2}, \mathrm{PPh}_{3}, \mathrm{Et}_{3} \mathrm{~N}, \mathrm{DMF}, 80{ }^{\circ} \mathrm{C}, 20 \mathrm{~h}$ & starting material \\
5 & $\mathrm{Pd}(\mathrm{OAc})_{2}, \mathrm{PPh}_{3}, \mathrm{AcONa}^{\mathrm{D}} \mathrm{DF}, 80{ }^{\circ} \mathrm{C}, 20 \mathrm{~h}$ & starting material \\
\hline 6 & $\mathrm{Pd}(\mathrm{OAc})_{2}, \mathrm{PPh}_{3}, \mathrm{HCOONa}, \mathrm{DMF}, 80^{\circ} \mathrm{C}, 20 \mathrm{~h}$ & mixture of products
\end{tabular}

The structure of 92 was characterised by using one- and two-dimensional NMR techniques. The spectra of $\mathbf{9 2}$ show the same spectral patterns as the analogous aromatic system of $\mathbf{7 4 .}$ 
In general the formation of 73, 74, 91 and 92 can be rationalized by several possible mechanistic pathways, (Scheme 32.). In the first pathway, the cascade might go throughout a twofold Heck reaction followed by either $6 \pi$-electrocyclization or 6-endotrig carbopalladation and then $\beta$-hydrogen elimination to form three fused six-membered rings or bisannelated benzene derivative 97. The other possibility is that instead of the $6 \pi$-electrocyclization or the 6-endo-trig carbopalladation, a 5-exo-trig carbopalladation will take place and neopentyl-like system 94 will be formed. Farther 3-exo-trig carbopalladation will yield 95 which will undergo ring opening to give 96 followed by $\beta$ hydrogen elimination to produce 97 . In the event that $6 \pi$-electrocyclization or 6-endo-trig carbopalladation occurred, the outcome of the cascade reaction, would always be three fused six-membered rings or bisannelated benzene regardless the substituent type at the terminal alkyne (R) of $\mathbf{9 9}$. However, this will not be the case when different substituents other than phenyl or tert-butyldimethylsilyl group at the terminal alkyne are used. It will be shown in the next sections that the cascade reaction of $\mathbf{9 9}$ offers different types of polycyclic systems depending on the nature of the substituent at the terminal triple bond and this, in fact, makes the 5-exo-trig carbopalladation route more convenient to explain the formation of 73, 74, 91 and 92. 
<smiles>[R]c1cc2c(c3c1CCCC3(F)F)CCCC2</smiles>

97<smiles>[R]C#CCCCCC#CCCC(F)(F)CC(=C)Br</smiles>

99

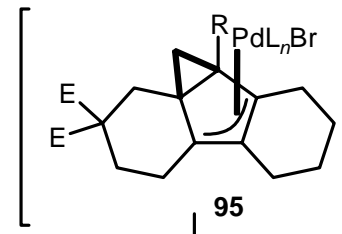

cyclopropyl ring openning

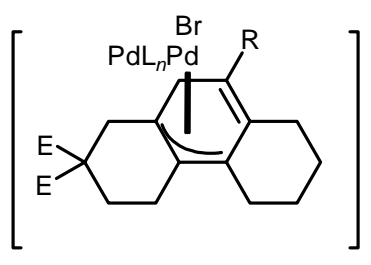

96

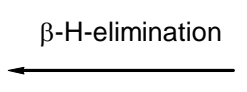

(n)

$\left\{\begin{array}{c}98 \text {-electrocyclization } \\ \text { or } \\ 6 \text {-endo-trig }\end{array}\right.$
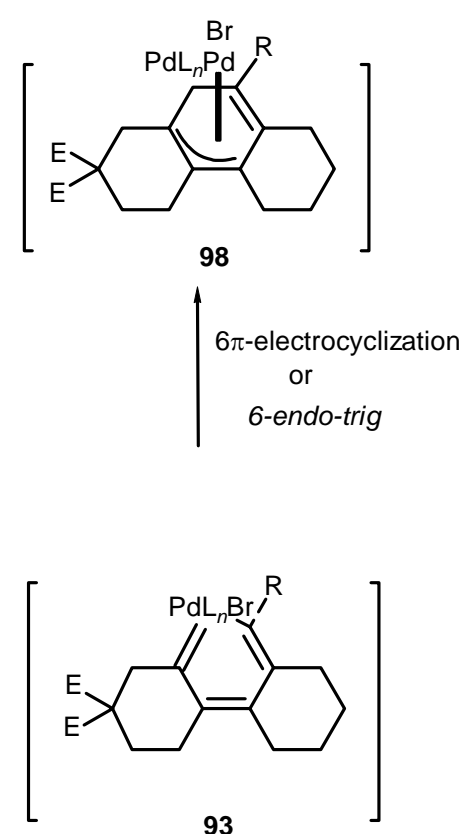

5-exo-trig carbopalladation $\left.\right|^{93}$

3-exo-trig carbopalladation

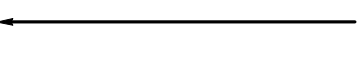

$\beta$-H-elimination

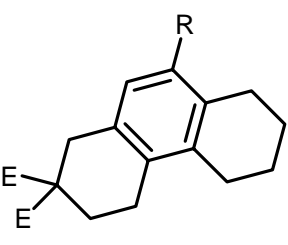

97

Scheme 32. $\mathrm{E}=\mathrm{CO}_{2} \mathrm{Et}, \mathrm{R}=\mathrm{Ph}, t \mathrm{BuMe}_{2} \mathrm{Si}$ 
3. Palladium-catalyzed oligocyclization of terminally alkoxycarbonyl-Substituted 2bromo-14-tetradec-1-ene-7,13-dyne

\subsection{Prologue}

It was mentioned earlier that the nature of the substituents and the substitution pattern at the non-brominated terminal alkene of 2-bromo-12-dodec-1,11-diene-6-yne would determine the cascade's pathway. Thus, replacing the phenyl with an ester group would convert the terminal alkene into an activated dienophile and consequently a pathway involving intramolecular Diels-Alder reaction would become another possible pathway for such cascade. This indeed was the case when $\mathbf{1 0 0}$ had been treated at $130{ }^{\circ} \mathrm{C}$ with palladium acetate and potassium carbonate in acetonirile to afford the Diels-Alder product 101 and the triene system 102, (Scheme 33.). ${ }^{[30]}$

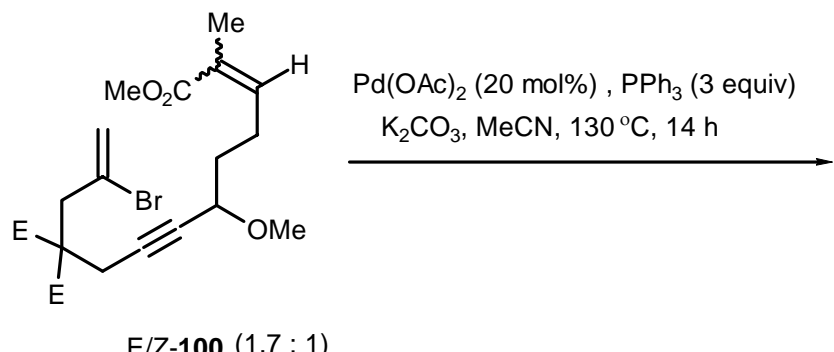

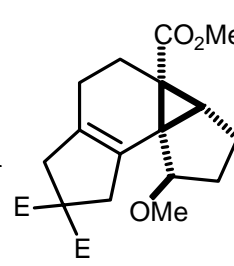

$101(47 \%)$

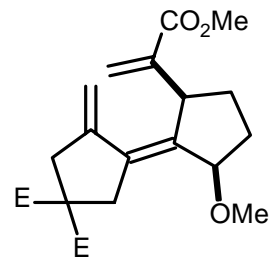

cis-102 (31\%)

Scheme 33. $\mathrm{E}=\mathrm{CO}_{2} \mathrm{Et}$

Similar observations were obtained by Trost et al. However, in this case it was presumed that the Diels-Alder would be induced by the steric strain of the activated diene $\mathbf{1 0 4}$ (Scheme 34.). ${ }^{[32]}$ 


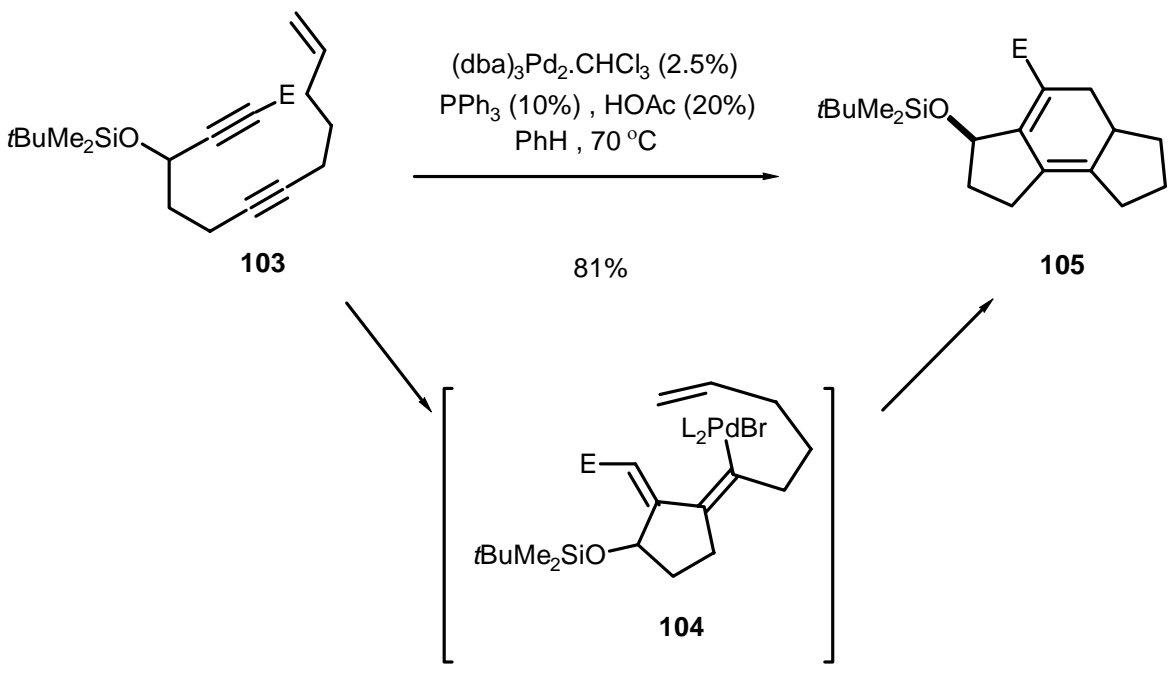

Scheme 34. $\mathrm{E}=\mathrm{CO}_{2} \mathrm{Me}$

Although it might be slowed down by increasing the length of the tether linking the diene with dienophile, it would be anticipated, based on the above results, that the cascade reaction of 106, wherein the terminal triple bond is substituted with an alkoxycarbonyl group, may go through a one Heck reaction followed by an intramolecular Diels-Alder reaction of $\mathbf{1 0 7}$ to give $\mathbf{1 0 8}$ and finally $\beta$-hydrogen elimination to produce three fused sixmembered rings or a bisannelated methyl benzoate system 109, (Scheme 35.).

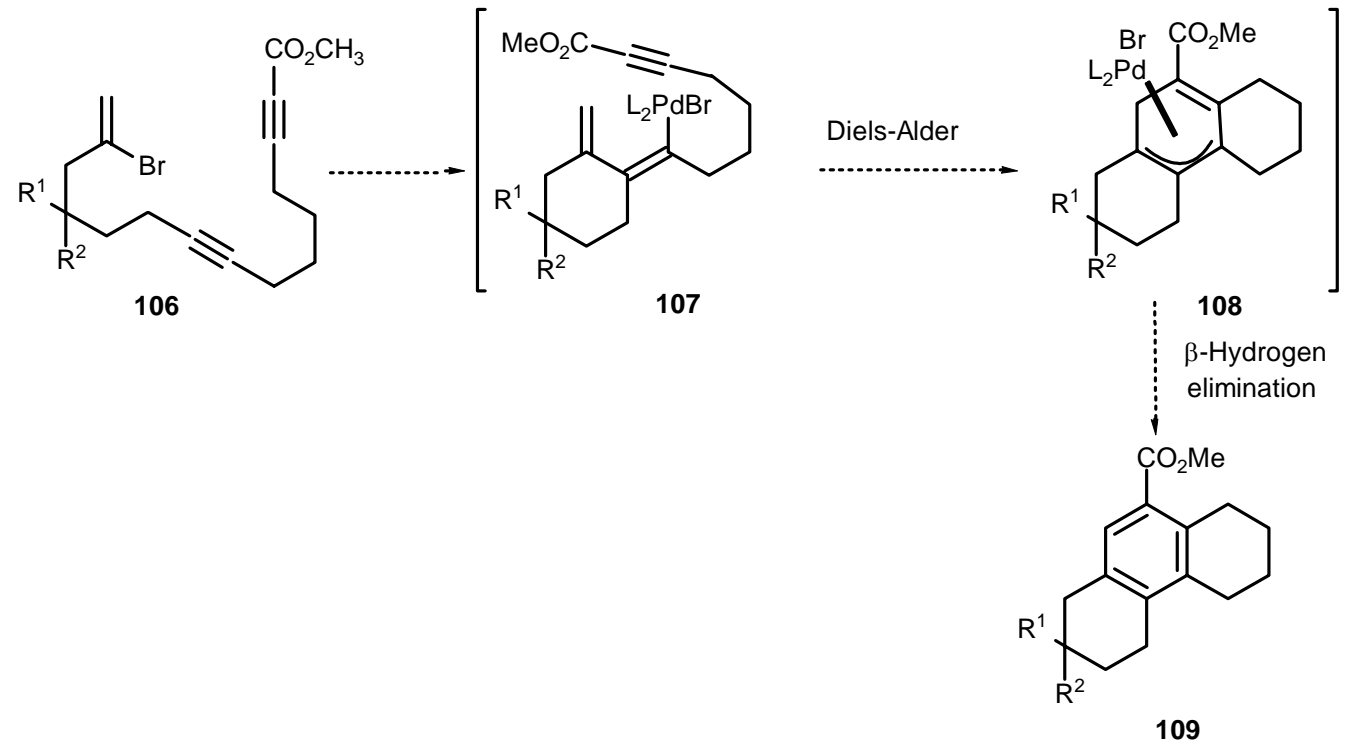

Scheme 35. $\mathrm{R}^{1}=\mathrm{R}^{2}=\mathrm{CO}_{2} \mathrm{Me}$ 
To probe this hypothesis and to examine the effect of replacing an electron donating group with an electron withdrawing group at the terminal triple bond, compounds such as 110 \& 111 are needed to be synthesized and cyclized.

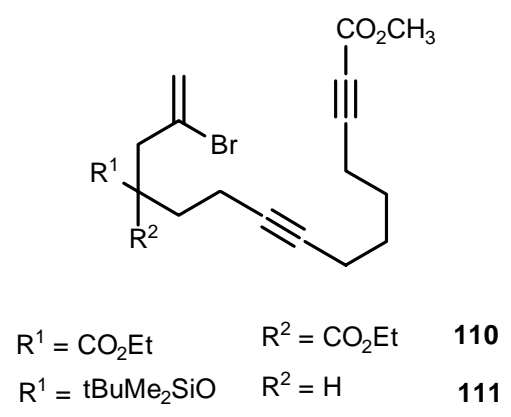

Fig 3.

\subsection{Synthesis of the alkoxycarbonyl-substituted precursors}

Again the synthesis of $\mathbf{1 1 0}$ can be achieved starting from 1,7-octadiyne, (Scheme 36.). Thus, treating the lithiated 1,7-octadiyne with ethylene oxide in the presence of etheral solution of boron triflouride at $-78{ }^{\circ} \mathrm{C}$ in THF, gives the alcohol 112 in a $60 \%$ yield. It should be noted that the reaction should be quenched at $-78{ }^{\circ} \mathrm{C}$ because leaving the reaction to warm up to room temperature will lead to polymerization products instead of the desired product. The alcohol 112 is then converted into the mesylate and coupled with sodium malonate to afford the substituted malonate 114.114 is then treated at $70{ }^{\circ} \mathrm{C}$ with sodium hydride and 2,3-dibromopropene to afford 115 in a rather poor yield. As it was mentioned before, the nucleophilic substitution at the allylic bromide proceeds via $\mathrm{S}_{\mathrm{N}} 2$ type mechanism which is proved to be highly sensitive to the solvent polarity. Therefore, it was found that modifying the solvent polarity by adding a small portion (10$15 \%$ by volume) of DMF to DME, improves the yield of such substitution significantly and 115 can be obtained in a 72\% yield. The final step involves the attachment of the ester group at the terminal alkyne. Conducting this step, which requires using a strong base to abstract the acetylenic hydrogen, in the presence of both the base-sensitive malonate unit and the vinyl bromide makes this step very difficult to be achieved. However, carrying out this reaction at $-78{ }^{\circ} \mathrm{C}$ using LDA (lithium diisopropyl amide) will offer the desired precursor 110 in a $44 \%$ yield. Trying to use $n$-butyl lithium instead 
of LDA will decrease the yield and results in a complicated mixture to separate.

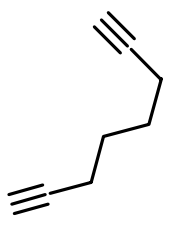

60

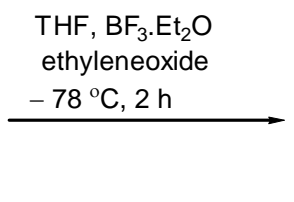

$55 \%$

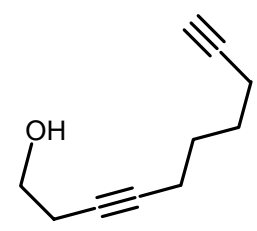

80\% $\begin{gathered}112 \\ \mathrm{MsCl} \mathrm{Et}_{3} \mathrm{~N} \\ \mathrm{CH}_{2} \mathrm{Cl}_{2} \\ -15-0^{\circ} \mathrm{C}, 12 \mathrm{~h}\end{gathered}$

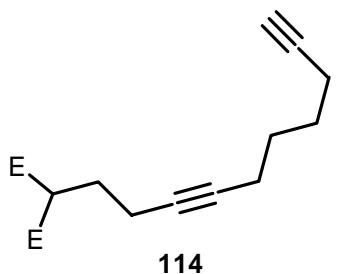

114 dimethylmalonate, $\mathrm{NaH}$ THF/DMF $\mathrm{KI}, 70^{\circ} \mathrm{C}$

$72 \%$

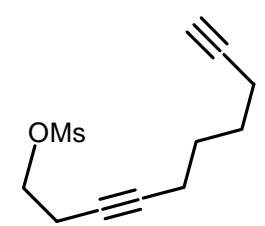

113 2,3-dibromopropene, $\mathrm{NaH}$
DME/DMF
$70^{\circ} \mathrm{C}$ $75 \%$<smiles>C#CCCCCC#CCCC(F)(F)CC(=C)Br</smiles>

115

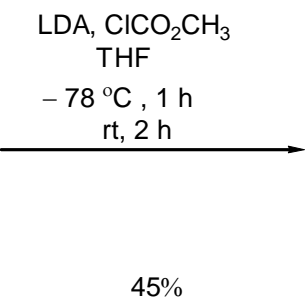

110

Scheme 36. $\mathrm{E}=\mathrm{CO}_{2} \mathrm{Me}$ 
In a similar manner like 49 and 80, synthesis of 111 was achieved by two routes, (Scheme 37.). In Route A compound 59 can be prepared by linking the acetal 64 to 1tert-butyldimethylsilyl hex-1-yn (82), (Scheme 29.), and then removing the silyl group from the terminal alkyne of the produced diyne $\mathbf{8 9}$ by tetrabutylammonium fluoride, ${ }^{[52]}$ while in Route B compound 59 can be prepared by coupling the lithiated 1,7-octadiyne with 61. Treating 59 with 2,3-dibromopropene in the presence of powder tin will offer the alcohol 116 which is then protected by tert-butyldimethylsilyl chloride to produce 117. When 117 is treated with $n$-butyl lithium, the abstraction of the acetylenic proton is accompanied by transmetellation at the vinylic bromide which leads to the formation of 118 instead of 111. To overcome this difficulty, LDA is used as a base to furnish $\mathbf{1 1 1}$ in a $48 \%$ yield. 


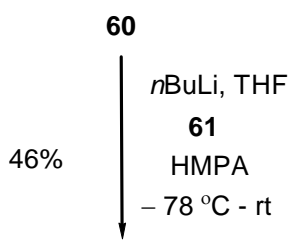

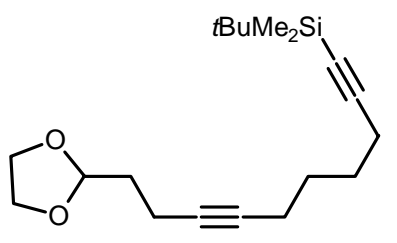

89

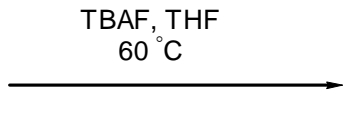

$80 \%$

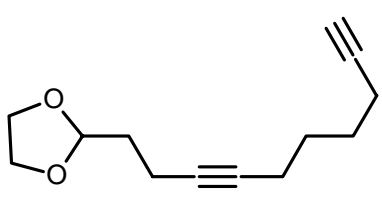

$52 \% \quad \begin{gathered}59 \\ \mathrm{Sn}, \mathrm{HBr} \\ \mathrm{Et}_{2} \mathrm{O} / \mathrm{H}_{2} \mathrm{O} \\ \text { 2,3-dibromopropene }\end{gathered}$<smiles>C#CCCCCC#CCC[C@H](CC(=C)Br)O[Mg]C(C)(C)C</smiles>

tBuMe ${ }_{2} \mathrm{SiCl}$, Imidazole DMF, $55^{\circ} \mathrm{C}$ $24 \mathrm{~h}$

$89 \%$<smiles>C#CCCCCC#CCC[C@H](O)CC(=C)Br</smiles>

116

nBuLi , THF chloromethylformate $-78^{\circ} \mathrm{C}, 1 \mathrm{~h}$ $40 \% \quad \begin{gathered}\text { LDA }, \text { THF } \\ \text { chloromethylformate } \\ -78^{\circ} \mathrm{C}, 1 \mathrm{~h} \\ \mathrm{rt}, 2 \mathrm{~h}\end{gathered}$<smiles>C=C(Br)C[C@H](CCC#CCCCCC#CC(=O)OC)O[Mg]C(C)(C)C</smiles><smiles></smiles><smiles>C=C(C[C@@H](CCC#CCCCCC#CC(=O)OC)O[Mg]C(C)(C)C)C(=O)OC</smiles>

118

Scheme 37. 


\subsection{Palladium-catalyzed oligocyclizations of alkoxycarbonyl-substituted precursors}

Unexpectedly, when 110 is treated at $60{ }^{\circ} \mathrm{C}$ with palladium acetate $(10 \mathrm{~mol} \%)$ in the presence of sodium carbonate and triphenyl phosphine in acetonitrile, the tetracyclic system 119 is formed,(Scheme 38.).

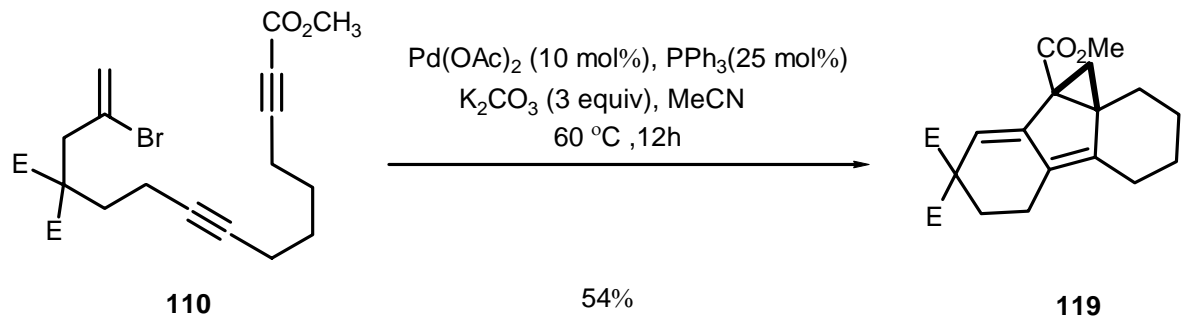

Scheme 38. $\mathrm{E}=\mathrm{CO}_{2} \mathrm{Me}$

Examining the ${ }^{13} \mathrm{C}-\mathrm{NMR}$ spectrum of $\mathbf{1 1 9}$ shows only four olefinic carbons at $\delta=144.58$, 143.23, $126.21 \& 116.21$ ppm which indicate that there are only two C-C double bonds and a tetracyclic system. All the carbonyls' carbons chemical shifts are down field shifted, i.e. they have values higher than $170 \mathrm{ppm}$, which indicates that the three carboxylate groups are situated on saturated carbons. This is also reinforced by the IR spectrum which shows only abroad band at $1730 \mathrm{~cm}^{-1}$ while there are no bands between1690-1700 $\mathrm{cm}^{-1}$ which are characteristic for carboxylates at unsaturated carbons. DEPT elucidates the formation of two quartet carbons at $\delta=36.72 \& 45.87 \mathrm{ppm}$ and a methylene group $\left(\mathrm{CH}_{2}\right)$ at $\delta=39.13 \mathrm{ppm}$ corresponding to the bridge head carbons and the bridging carbon (cyclopropyls' carbon) respectively. Furthermore, it shows that there is only one olefinic $(\mathrm{CH})$ carbon and three olefinic quartet carbons which indicates the presence of one trisubstituted double bond and one tetrasubstituted double bond. gHSQC establishes a direct correlation between the methylene group carbon signal at $\delta=39.13$ ppm and two doublets in ${ }^{1} \mathrm{H}-\mathrm{NMR}$ spectrum at $\delta=1.94,{ }^{2} \mathrm{~J}=3.0 \mathrm{~Hz}$ and $1.06,{ }^{2} \mathrm{~J}=3.0$ $\mathrm{Hz}$ corresponding to two geminal protons located on this carbon. The big difference in the chemical-shift value between these two protons can be attributed to the anisotropic effect of one of the double bonds on one of these protons. H/H COSY shows that these two protons are coupled to each other. It also shows that the olefinic proton, which appears as a singlet at $\delta=6.03 \mathrm{ppm}$, and the bridging protons are not coupled with any other proton in the compound. This is in agreement with the proposed regioisomer. The 
correlation between the methyl ester protons and the bridge head carbon at $\delta=36.72$ in HMBC (long range $\mathrm{C} / \mathrm{H}$ correlation) affirms that the methyl ester group is located on this carbon. The fact that the olefinic proton has only two correlations, one with one of the olefinic carbons and the other with ester substituted bridge head carbon $\delta=36.72$ excludes any possibility for the formation of any other tetracyclic systems such as $\mathbf{1 2 0}$ (Fig 5.). Fig 4 illustrates a summary of HMBC correlations.

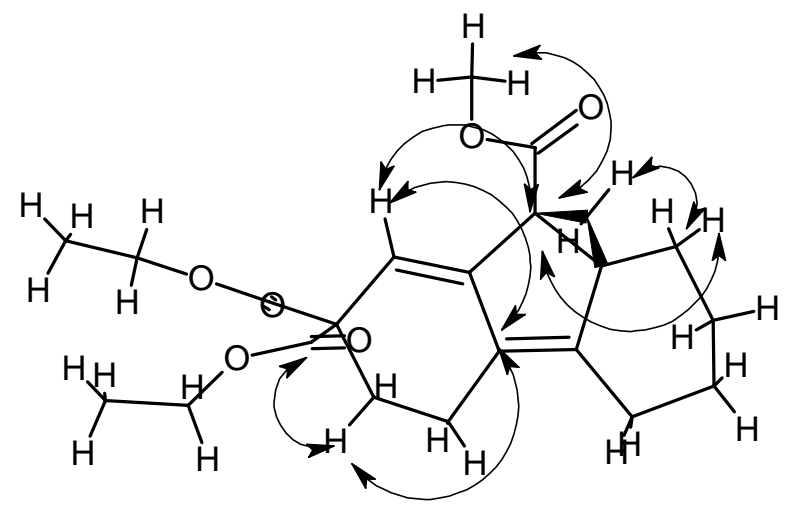

Fig 4: Summary of HMBC Correlations of 119

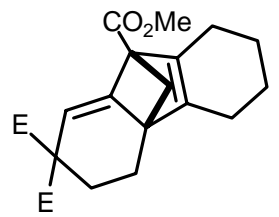

120

Fig 5.

Apparently, the ester group has a drastic effect on the NMR properties of the cycloproyl moiety of such systems. While in unsubstituted fused cyclopropyl systems, such as $\mathbf{1 2 1},{ }^{[33]}$ the cyclopropyl's carbon and the protons attached to it appear up field at around 25 ppm and 0.0-1.5 ppm respectively, the cyclopropyl's carbon and the protons attached to it in $\mathbf{1 1 9}$ are deshielded and appear down field at $39.13 \mathrm{ppm}$ and 1.0-2.0 ppm respectively. However, the $\alpha$-carbon to the ester group is sheilded and it appears up-field at $\delta=36.72$. Clearly the ester group in such system has $\beta$-deshielding effect while it has $\alpha$-shielding effect. 


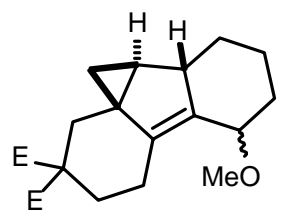

121

Fig 6.

Similarly, when 111 is treated with palladium acetate in the presence of potassium carbonate and triphenyl phosphine in actonitrile, 122 is formed in a $19 \%$ as a 2:1 diastereomeric mixture, Scheme 39.<smiles>C=C(Br)CC(CCC#CCCCCC#CC(C)=O)OC(C)C</smiles>

111

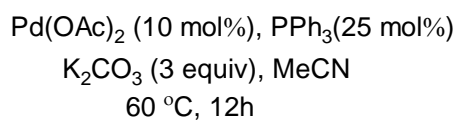

$19 \%$

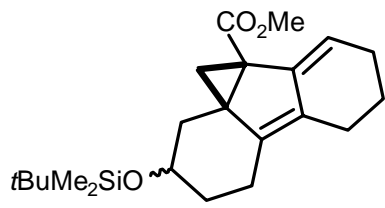

122

Scheme 39.

Compound 122 shows the same spectral properties as 119. However, the olefinic proton appears as a triplet at $5.89 \mathrm{ppm}$ which gives rise to further two possible compounds, $\mathbf{1 2 3}$ and 124. H/H COSY shows no correlation between this olefinic proton and the $\alpha$-proton to the silyloxy group which excludes the formation of 123. Moreover, HMBC shows a strong correlation between this proton and the carbon bearing the ester group which excludes the formation of 124 Fig (7.).

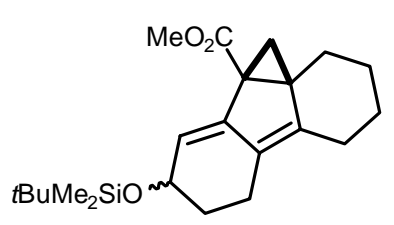

123

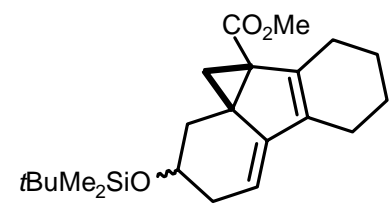

124

Fig 7. 
3.4. The mechanism of palladium-catalyzed oligocyclization of the alkoxycarbonylsubstituted precursors

Clearly the formation of $\mathbf{1 1 9}$ \& $\mathbf{1 2 2}$ discards the intramolecular Diels-Alder reaction as well as a possible $6 \pi$-electrocyclization. The mechanism leading to the formation 119 \& 122 is illustrated in Scheme 40. After the two-fold Heck reaction, a further carbapalladation takes place in a 5-exo-trig fashion to form the neopentyl-like system 126 which further undergoes a 3-exo-trig carbapalladation to give the cyclopropyl intermediate 127. Cyclopropyl-to-homoallyl rearrangement will yield the diene system 128 which undergoes a 3-exo-trig carbapalladation to give 129 followed by $\beta$-hydrogen elimination to produce $\mathbf{1 1 9 .}$ 


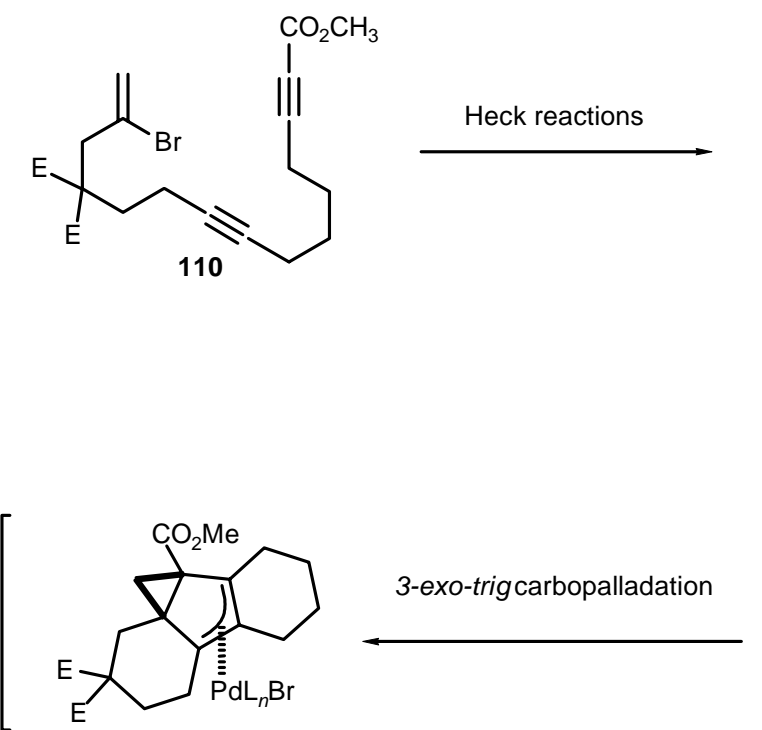

127

cyclopropyl to homoallylrearrangement

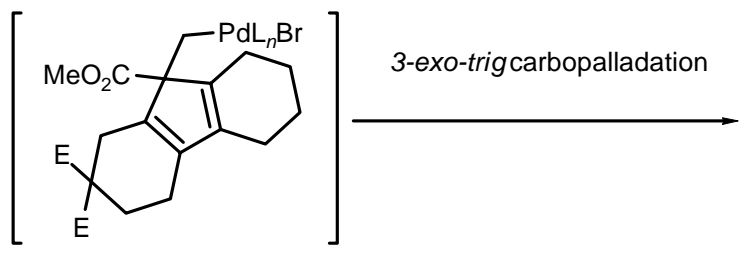

128
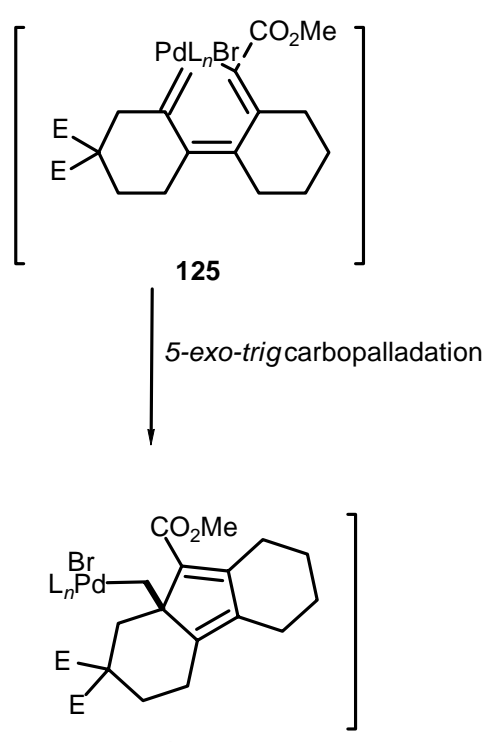

126

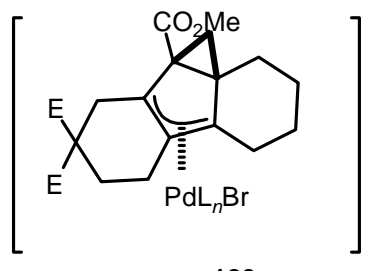

129

$\beta$-Hydrogen elimination

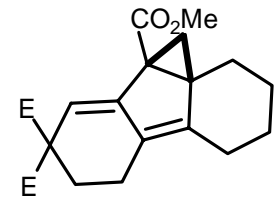

119

Scheme 40. $\mathrm{E}=\mathrm{CO}_{2} \mathrm{Me}$ 
4. Palladium-catalyzed oligocyclization of terminally alkoxycarbonyl-substituted 10(2-bromoallyloxy)-1,7-decadiyne

\subsection{Prologue}

In the previous section, it was mentioned that introducing an ester group into the terminal triple bond would result in tetracyclic systems such as $\mathbf{1 1 9}$ and $\mathbf{1 2 2}$. The formation of such systems eliminates the possibility that the cascade proceeds via $6 \pi$ electrocyclization or Diels-Alder reaction.

Nonetheless, when the carbon skeleton bears two oxygen atoms (two methylene groups are replaced by two oxygen atoms) compound 130, only can the aromatic compound 131 be isolated, (Scheme 40.). ${ }^{\text {[53] }}$ Obviously, the mechanism of formation of $\mathbf{1 3 1}$ is similar to that of 73 \& 71, which includes 5-exo-trig step, (Scheme 32.).
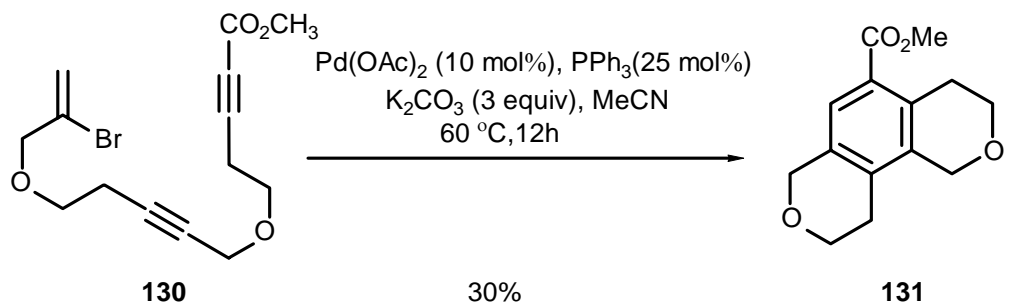

Scheme 41.

It is interesting to study the effect when only one methylene group is replaced by one oxygen atom or when the carbon skeleton bears one oxygen atom, e.g. compound 132.<smiles>C=C(Br)COCCC#CCCCCC#CC(C)=O</smiles>

Fig 8. 
4.2. Synthesis and oligocyclization of the alkoxycarbonyl-substituted heteroatom-tethered precursor.

The synthesis of 132 can be achieved starting from 1,7-octadiyne, (Scheme 42.). Thus, treating the lithiated 1,7-octadiyne with ethylene oxide in the presence of borontriflouride ether complex affords the alcohol 112 which is attached to 2,3-dibromopropene by regular Williamson reaction to give the ether 133 in a 42\% yield. Treating 133 with LDA and chloromethylformate at $-78{ }^{\circ} \mathrm{C}$ gives 132 in a $69 \%$ yield.

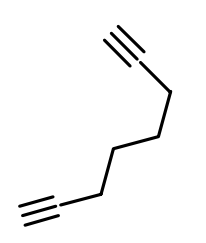

60

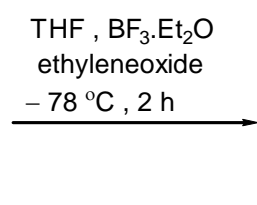

$55 \%$

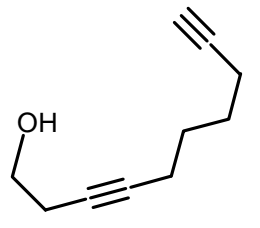

112

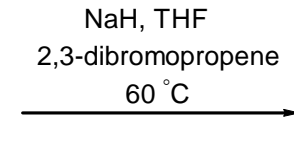

$42 \%$<smiles>C=C(Br)COCCC#CCCCCC#CC(C)=O</smiles>

132

Scheme 42.

When 132 is treated at $110{ }^{\circ} \mathrm{C}$ with palladium acetate (10 mol\%), triphenylphosphine (25 mol\%) and sodium carbonate in acetonitrile, compounds 134, 135 and 136 are formed in 18\%, $8 \%$ and 3\% yield respectively, (Scheme 43.). 


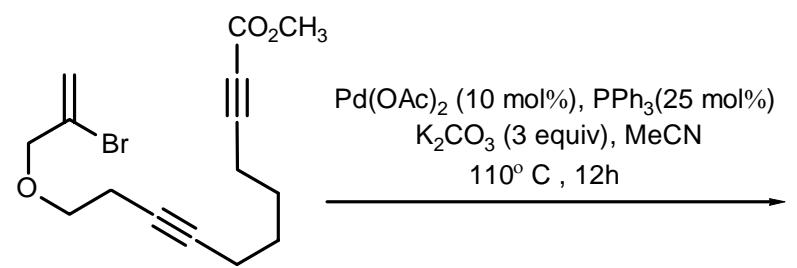

132

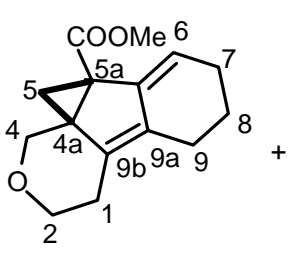

$134(18 \%)$<smiles>CC(=O)c1cc2c(c3c1CCCC3)CCOC2</smiles>

$135(8 \%)$

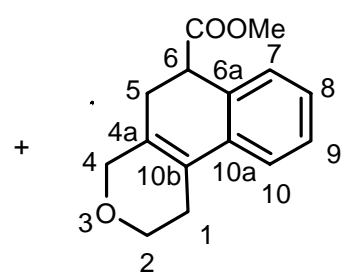

$136(3 \%)$

Scheme 43.

Fortunately, compound $\mathbf{1 3 4}$ affords unambiguous spectra which confirms the structure of 134 and allows us to conduct further NMR experiments to exclude any alternative structure. ${ }^{1} \mathrm{H}-\mathrm{NMR}$ and ${ }^{13} \mathrm{C}-\mathrm{NMR}$ spectra show similar patterns as those for 119. The bridging carbon (cyclopropyl's carbon) also appears at $\delta=37.29 \mathrm{ppm}$ and the two protons connected to it also appear as two doublets at $\delta=1.10 \& 2.05 \mathrm{ppm}$. The position of the cyclopropyl ring with respect to the heterocyclic ring enables us to assign the structure clearly from HMBC spectrum. A strong coupling can be observed between C-4 protons (H-4) (adjacent to the oxygen atom) and the bridging methylene carbon (cyclopropyl's carbon) C-5 and vice versa, i.e. between the C-5 protons (H-5) and the C4 carbon. The size of the coupling, and hence the intensity of the correlation, can be determined by the dihedral angles (Karplus relation) and the number of bonds separating the two coupled proton and carbon. ${ }^{[54]}$ Providing that, for instance, 137 were the correct structure, the coupling between the bridging methylene carbon $(\mathrm{C}-14)$ and $\mathrm{C}-6$ protons (H-6) would take place through four bonds and, consequently, the resulting coupling constant $\left({ }^{4} J_{\mathrm{C}-\mathrm{H}} \leq 1 \mathrm{hz}\right)$ would be so small so that the correlation can not be detected. Moreover, the HMBC spectrum of $\mathbf{1 3 4}$ shows a strong correlation between C-4 protons (H-4) and the bridge head carbon C-4a $\delta=42.87 \mathrm{ppm}$. Such correlation would not appear were the structure 137 the right compound. The HMBC proves that $\mathbf{1 3 4}$ is the right structure for these tetracyclic systems and it indicates that any other structure, such as 137, can not be right. (Fig 9.) summarizes the HMBC correlations of $\mathbf{1 3 4 .}$ 


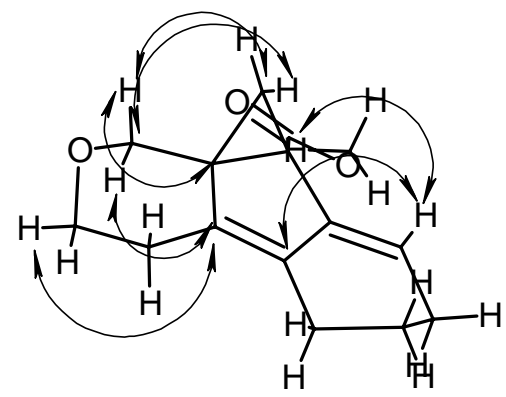

Fig 9: Summary of HMBC Correlations of $\mathbf{1 3 4}$

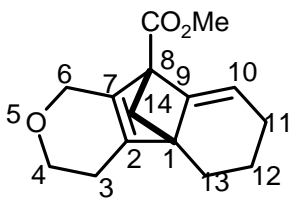

137

Fig 10.

The presence of the cyclopropyl moiety can be further proved by NOE experiments. Fig 11 shows a short distance between the exo-bridging methylene proton (exo-H-5) and the C-4 equatorial proton Heq-4, whereas such distance is quite large in the case of $\mathbf{1 3 7}$. Therefore, upon irradiating exo-H-5, we would expect NOE on the Heq-4 and the same thing would be observed for exo-H-5 upon irradiating Heq-4. From Fig 11 it can be seen that there would be insignificant NOEs between the endo-H-5 and both the Heq-4 and the Hax-4 (the axial proton of C-4) or between the Hax-4 and the two protons of C-5 because these protons are too far away to be involved in such NOEs. Thus, when the exo-H-5 is irradiated, a strong enhancement on the Heq-4 is observed and vice versa. Only very small NOEs are observed on the Heq-4 and the olefinic proton (H-6) when the endo-H-5 is irradiated. NOE is observed on the Hax-2 when Hax-4 is irradiated. These NOEdifference experiments, illustrated in Fig 11, provide a sharp confirmation for the presence of the cyclopropyl moiety and the structure 134. At the same time they exclude any other structure. 


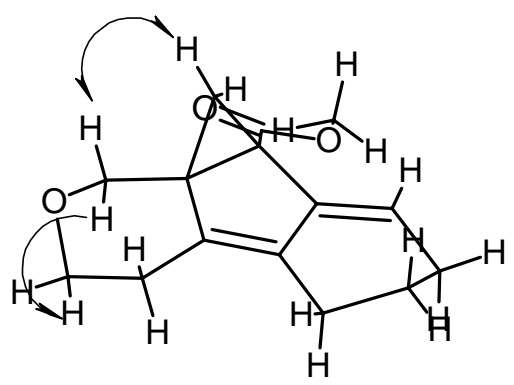

Fig 11: NOE Correlations of $\mathbf{1 3 4}$

The structure of $\mathbf{1 3 6}$ is determined by one- and two-dimensional NMR spectra. The ${ }^{13} \mathrm{C}$ NMR spectrum shows eight signals in the olefinic region which indicates that there are four double bonds. Four of these signals are corresponding to four $\mathrm{CH}$ carbons, while the other four are corresponding to four quartet carbons. The presence of the carbonyl carbon at $\delta=173.68 \mathrm{ppm}$ indicates that the methyl carboxylate group is situated on a saturated carbon. ${ }^{13} \mathrm{C}-\mathrm{NMR}$ also shows one $\mathrm{CH}$ at $\delta=43.34 \mathrm{ppm}$, corresponds to the estersubstituted carbon, two methylene groups in the aliphatic region at ( $\delta 24.52 \& 26.49$ ppm) and two methylene groups at $\delta=64.71 \& 67.93 \mathrm{ppm}$, which are obviously corresponding to the oxygen bonded methylenes. ${ }^{1} \mathrm{H}-\mathrm{NMR}$ shows the appearance of a multiplet in the aromatic region, which corresponds to the four aromatic protons, and a triplet at $\delta=3.71 \mathrm{ppm},{ }^{3} \mathrm{~J}=6.5 \mathrm{~Hz}$, which corresponds to the single proton of the ester substituted $\mathrm{CH}$ group. Mass spectroscopy confirms the loss of one hydrogen molecule $\left(\mathrm{H}_{2}\right)$ and one hydrobromide molecule $(\mathrm{HBr})$ which gives rise to a tricyclic system with four double bonds. $\mathrm{H} / \mathrm{H}$ COSY establishes a correlation between the proton at $\delta=3.71$ ppm and the two protons at $\delta=2.32 \& 2.43 \mathrm{ppm}$ of one of the two methylene groups, while the protons of the other methylene group establishes a correlation with protons of one of the oxygen-bonded methylenes. This clearly indicates that one of the methylene groups is adjacent to the ester substituted carbon while the other is a part of the heterocyclic moiety. The final evidence for the structure of $\mathbf{1 3 6}$ is derived from the HMBC spectrum. The proton at $\delta=3.71 \mathrm{ppm}$ shows a strong correlation with the ester carbonyl carbon, which affirms that the ester group is situated on this carbon, and another correlation with one of the methylene carbons at $\delta=26.49 \mathrm{ppm}$. It also shows strong correlations with two quartet olefinic carbons and one olefinic or aromatic $\mathrm{CH}$. Furthermore, HMBC shows a correlation between the protons of one of the oxygen- 
bonded methylene groups $(\mathrm{H}-2)$ and one of the olefinic quartet carbons at $\delta=124.41$ ppm, while the protons of the other oxygen-bonded methylene group show a correlation with this carbon and with another olefinic quartet carbon at $\delta=130.32 \mathrm{ppm}$. These later correlations confirm the position of the tetrasubstituted double bond. Fig 12 shows a summary of HMBC correlations which are in total agreement with the structure of $\mathbf{1 3 6 .}$

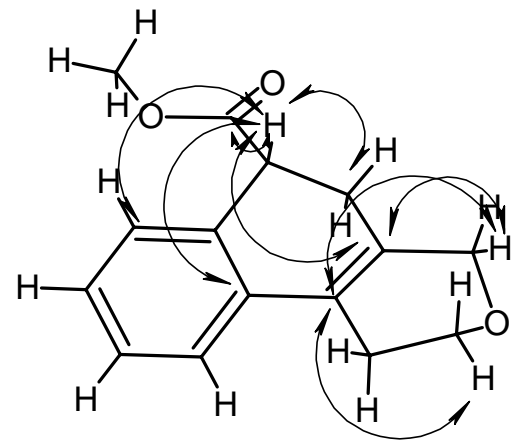

Fig 12: Summary of HMBC Correlations of 136

4.3. The mechanism of the palladium -catalyzed oligocyclization of the hetero-atom tethered precursor.

Compound 135 shows the same spectral patterns as $\mathbf{9 1}$ and $\mathbf{9 2 .}$

The mechanism of formation of $134 \& 135$ is similar to that of $119 \& \mathbf{9 1}$, (Scheme 44.) Thus, 3-exo-trig carbopalladation of the neopentyl-like system 137 yields the cyclopropyl intermediate complex 138 which might undergo either a $\beta$-hydrogen elimination to give 134 or cyclopropyl ring-opening to form the diene system 139. The later undergoes a further 3-exo-trig carbopalladation and cyclopropyl ring opening to offer 141 which undergoes $\beta$-hydrogen elimination either from the methylene group adjacent to the ester group to afford the aromatic compound $\mathbf{1 3 5}$ or from the methylene group of the annelated cyclohexyl moiety to afford the highly unstable intermediate $\mathbf{1 4 2}$ that undergoes a further double bond migration to produce the cyclohexadiene system 143. Oxidation of the later will afford the aromatic system 136. The last oxidation step might be invoked by the presence of palladium. Such palladium-induced oxidations of cyclohexadiene systems into aromatic system are frequently reported in the literature. ${ }^{[55]}$ 

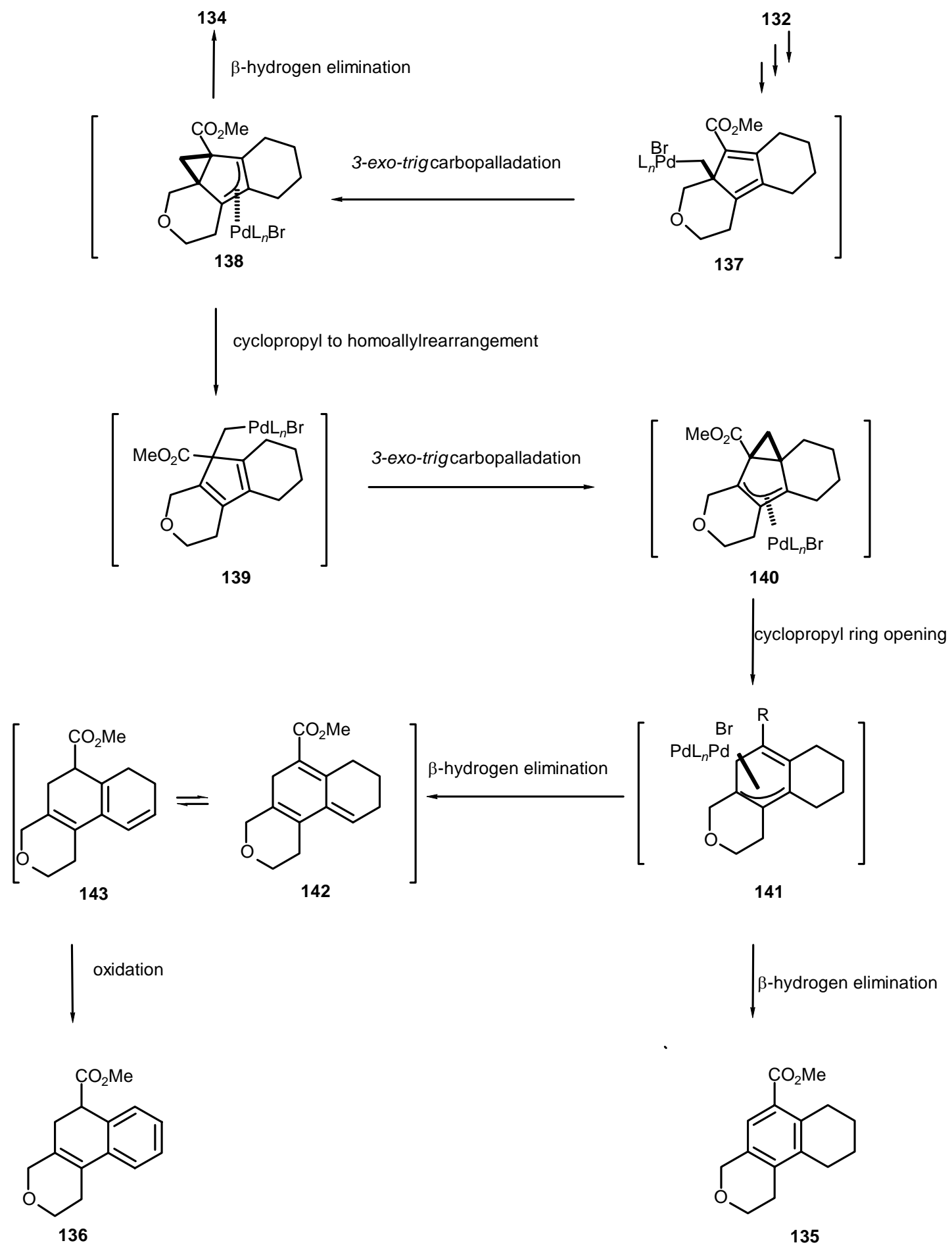

Scheme 44 .<smiles>CC(=O)c1cc2c(c3c1CCCC3)CCOC2</smiles>

135 
5. Palladium-catalyzed oligocyclization of terminally acetyl-Substituted 2-bromo-14tetradec-1-ene-7,13-dyne

\subsection{Synthesis of acetyl-substituted precursors}

Spurred by the results of the ester substituted terminal alkyne precursors 110 \& 111, it would be interesting to try other electron withdrawing groups such as the acetyl group. Therefore, precursors such as 144 and 145, (Scheme 45.), were to be synthesized and cyclized.

The synthesis of such precursors can be achieved in a similar way to that of their ester analogues. Thus, when 115 \& 117 are treated at $-78{ }^{\circ} \mathrm{C}$ with LDA and acetic anhydride in THF, 144 and 145 are formed in $40 \%$ and 61\% yield respectively, (Scheme 45.).
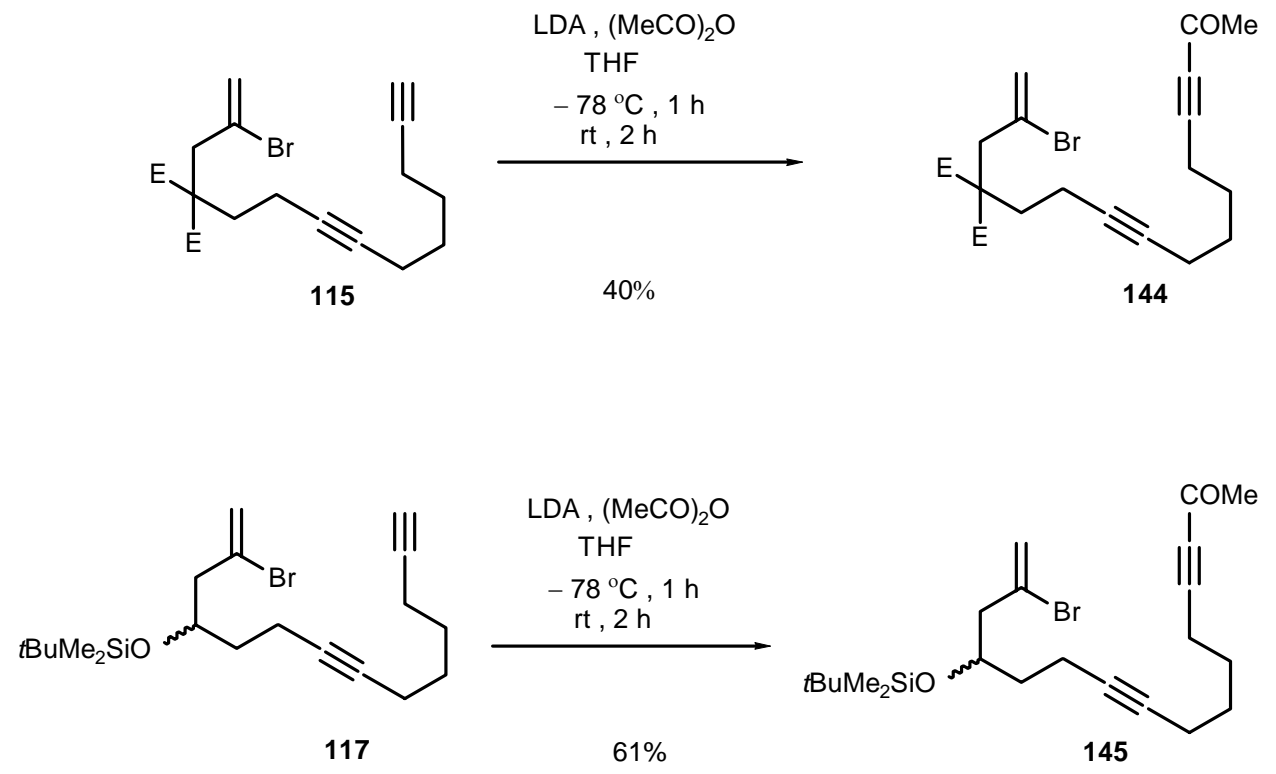

Scheme 45. $\mathrm{E}=\mathrm{CO}_{2} \mathrm{Me}$ 
5.2. Palladium-catalyzed oligocyclizations of acetyl-substituted precursors and their mechanism

Stunningly, when 144 is treated, at $65^{\circ} \mathrm{C}$, with palladium acetate (10 mol\%) in the presence of triphenyl phosphine (25 mol\%) and potassium carbonate in acetonitrile, compounds 146 and 147 are formed in a 25\% and 15\% yield respectively, (Scheme 46.).
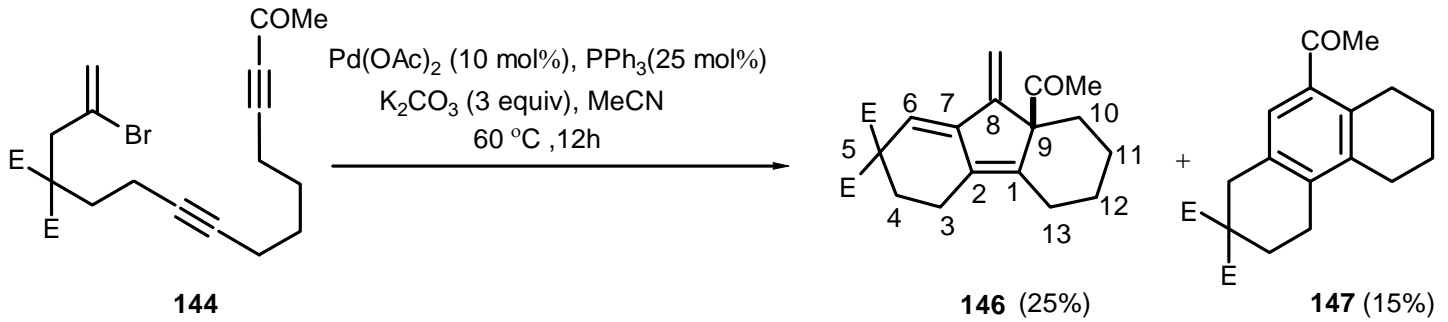

Scheme 46. $\mathrm{E}=\mathrm{CO}_{2} \mathrm{Me}$

The structure of 146 can easily be verified by NMR techniques, especially HMBC and H/H-NOESY. ${ }^{1} \mathrm{H}-\mathrm{NMR}$ spectrum shows three olefinic singlets at $\delta=6.00,5.51$ and 4.90 ppm corresponding to three olefinic protons. ${ }^{13} \mathrm{C}-\mathrm{NMR}$ spectrum shows six olefinic carbons, four quartets at $\delta=148.44,143.27,143.22 \& 132.56 \mathrm{ppm}$, one $\mathrm{CH}_{2}$ at $\delta=$ $107.19 \mathrm{ppm}$ and one $\mathrm{CH}$ at $\delta=110.25 \mathrm{ppm} .{ }^{13} \mathrm{C}-\mathrm{NMR}$ spectrum also shows a quartet at $\delta=67.24$ ppm. gHSQC indicates that the two olefinic protons at $\delta=5.51$ and $4.90 \mathrm{ppm}$ are attached to the methylene carbon at $\delta=107.19 \mathrm{ppm}$ and they have zero geminal coupling constant. Such pattern, was observed for similar cyclic systems. ${ }^{[56]}$ HMBC confirms the elucidated structure. The quartet carbon at $\delta=67.24 \mathrm{ppm}$ has a correlation with the protons of the acetyl group which indicates that the acetyl group is bonded to this carbon. It also shows a strong correlation with the protons of the exo-methylene group. This strong correlation can be attributed to the large coupling between such allylic protons and their corresponding allylic $\gamma$-carbon in such allylic systems $\left({ }^{3} J_{\underline{H}-\mathrm{C}=\mathrm{C}-\underline{\mathrm{C}}} \sim 15\right.$ $\mathrm{Hz}$ ), ${ }^{[54]}$ (of course the trans proton has a larger coupling constant, and hence a stronger correlation, to the quartet carbon than the cis-proton. The same situation applies when we consider the correlation between these protons and the quartet carbon of the trisubstituted double bond (C-7)). These correlations specify exactly the position and the substitution of this quartet carbon. The strength and the pattern of the other correlations in the HMBC spectrum are in consistence of the deduced structure 146. Fig 13 shows a summary these 
HMBC correlations.

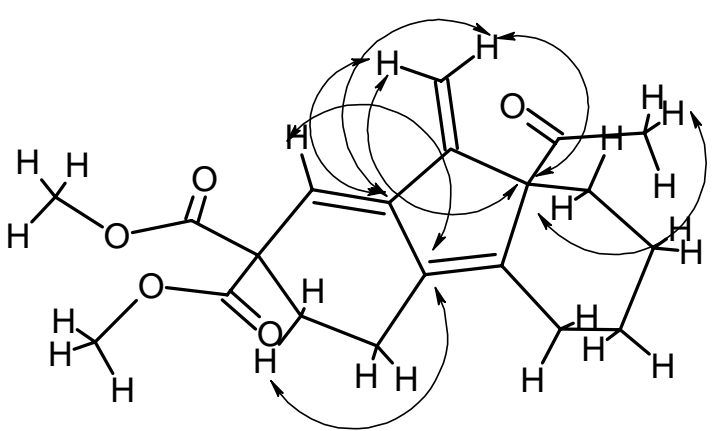

Fig 13: Summary of HMBC Correlations of $\mathbf{1 4 6}$

Further evidence which proves the structure 146 can be obtained from H/H.NOESY of 146. It reveals a strong correlation between the olefinic proton of the trisubstituted double bond and the exo-methylene protons. It also shows a correlation between the two geminal protons of the exo-methylene group. Fig 14 illustrates these space interactions.

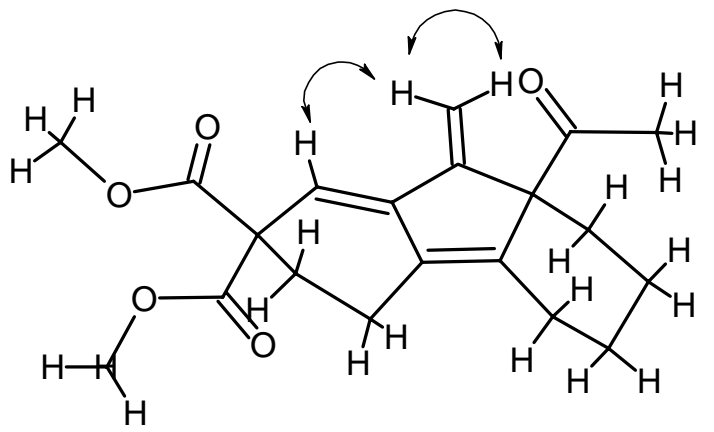

Fig 14: NOESY Correlations of 146

It is clear from the structure of $\mathbf{1 4 6}$ that the acetyl group has undergone a sort of migration. There are two possible mechanisms by which the formation of $\mathbf{1 4 6}$ can be explained. The first mechanism presumes that the diene system of $\mathbf{1 4 8}$, which is formed by the same sequence of steps illustrated in Scheme 40, undergoes a thermal 1,5-acyl migration to form 149. Apparently the equilibrium is shifted to the right by the fast formation of the stable palladium complex 149, i.e. the complexation step will overcome the reverse 1,5-acyl migration. Subsequent $\beta$-hydrogen elimination will furnish compound 146, (Scheme 47.). 


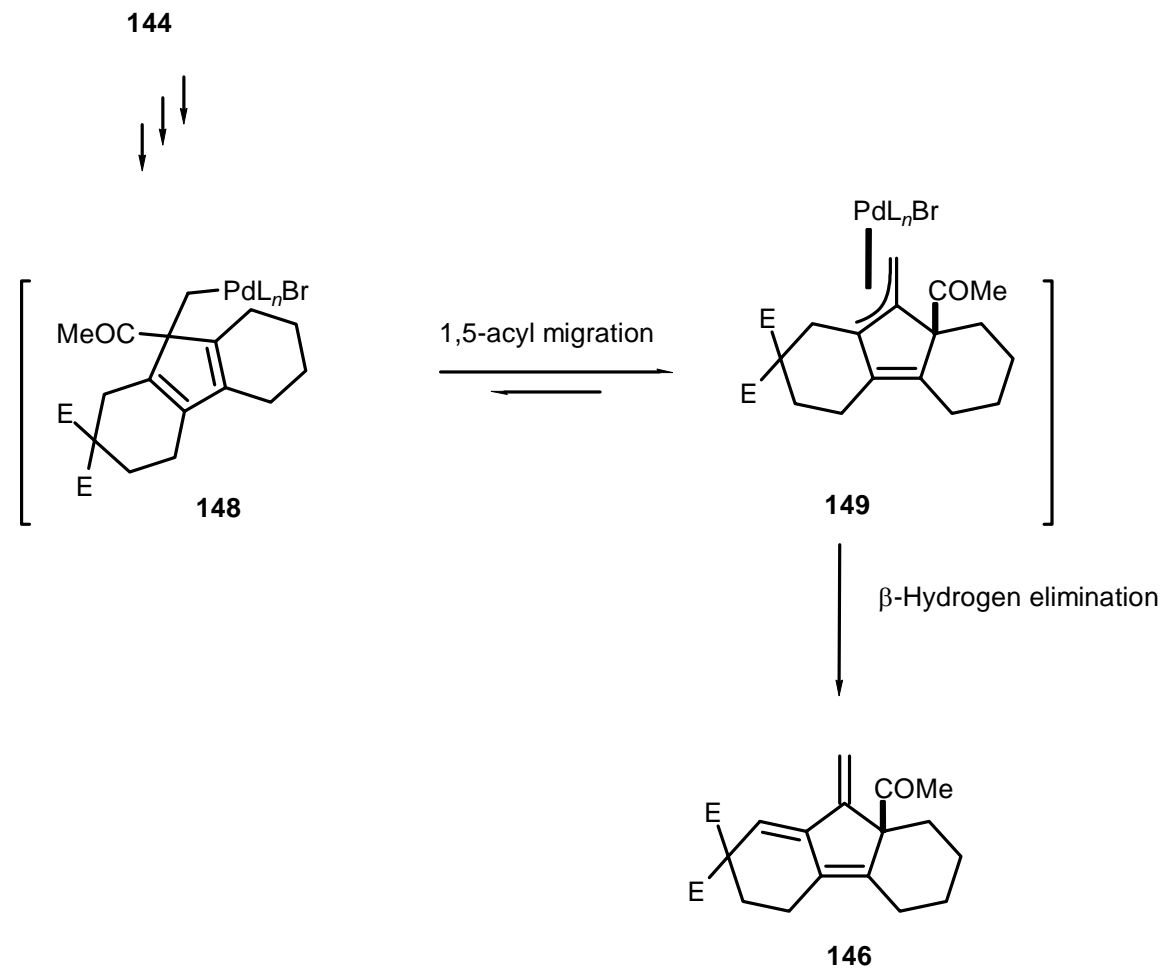

Scheme 47. $\mathrm{E}=\mathrm{CO}_{2} \mathrm{Me}$

There are a few reports in the literature which describe the thermal 1,5-acyl migration. ${ }^{[57]}$ However, such migration is usually induced photochemically. ${ }^{[58]}$

In an investigation about the thermal 1,5 migratory aptitude using indene, Scheme 48, it was found that the 1,5 migratory aptitude decreases in the following order: $\mathrm{HCO}>\mathrm{Bz} \sim$ Ac $>\mathrm{H}>$ vinyl $>$ CONHMe $>\mathrm{CO}_{2} \mathrm{Ph}>\mathrm{CO}_{2} \mathrm{Me}>\mathrm{CN} \sim \mathrm{C} \equiv \mathrm{C}>$ alkyl. $^{[59]}$ The low migratory aptitude of the methyl ester might explain why such migrations are not observed in the case of ester-substituted precursors.<smiles>[R]C1(C)C=C(C)c2ccccc21</smiles>

150
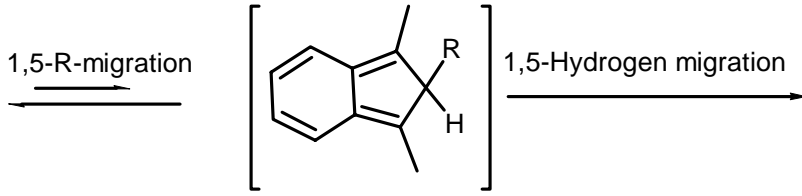

151<smiles>[R]C1=C(C)c2ccccc2C1([2H])C</smiles>

152

Scheme 48.

The second mechanism is based on recent findings by S. Uemura et al, which includes $\beta$ carbon elimination from cyclobutane systems to afford ketones or nitriles. ${ }^{[60]}$ Thus according to these results, the diene intermediate 148 would undergo $\beta$-carbon 
elimination to produce the fulvene system 153. Subsequently, one of the endo-fulvene's double bonds would undergo an insertion into the palladium-acetyl bond to form the complex 154, which by $\beta$-hydrogen elimination would afford 146, (Scheme 49.). Alkene insertion into palladium-acetyl bond was reported in literature. ${ }^{[61]}$

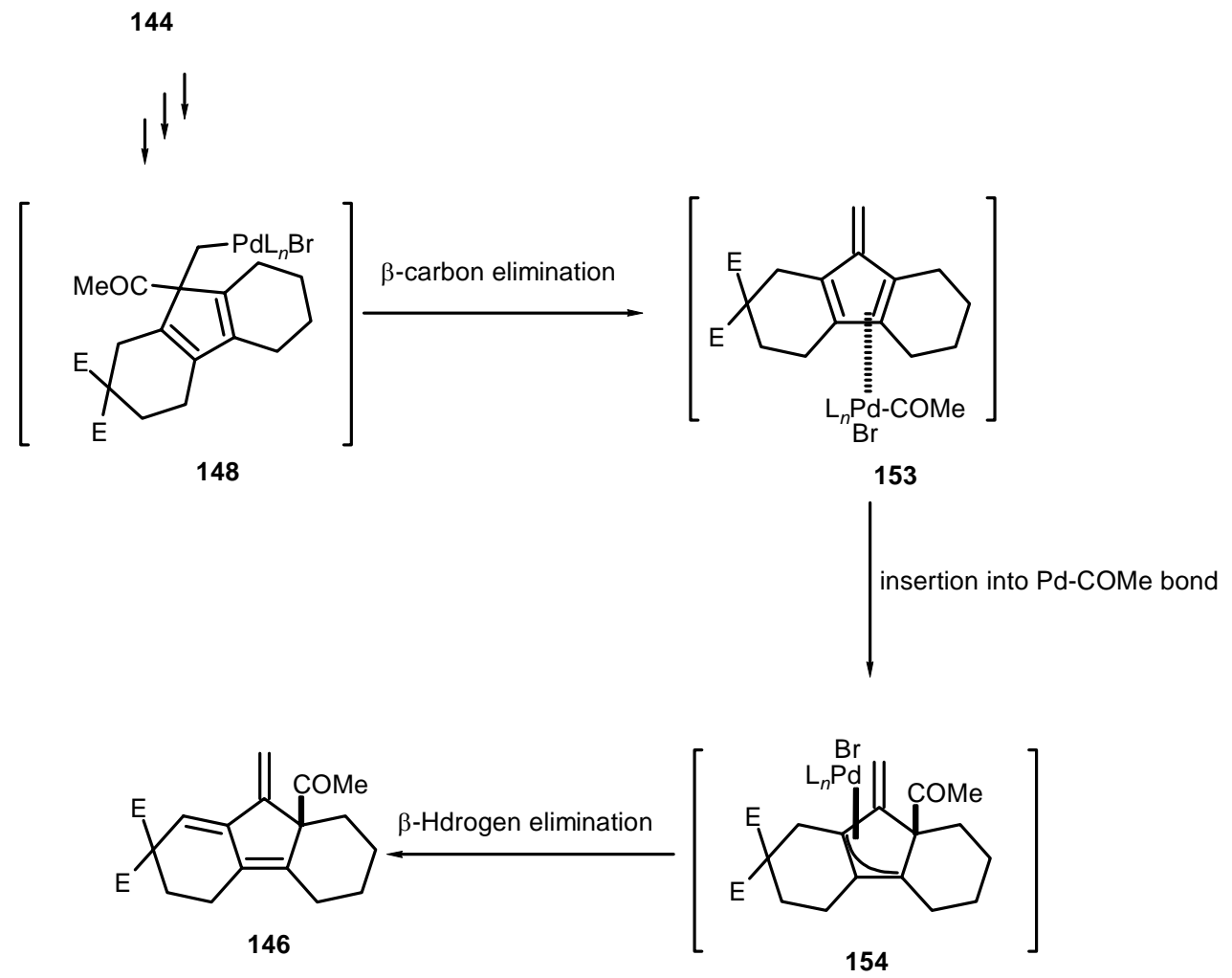

Scheme 49. $\mathrm{E}=\mathrm{CO}_{2} \mathrm{Me}$

Whether the cascade would follow the first or the second mechanism depends on the rate of the competing reactions for these mechanisms.

Upon treating 145 with palladium acetate in the presence of triphenylphosphine and potassium carbonate in acetonitrile, no reaction is observed and all the starting materials are recovered. However, when 145 is treated with palladium acetate (10 mol\%) in the presence of triphenylphosphine (25 mol\%) and sodium formate in DMF, a complicated mixture of diastereomers is formed. Nonetheless, compounds 155, 158, and an inseparable mixture of $\mathbf{1 5 6} \& \mathbf{1 5 7}$ were isolated and identified, (Scheme 50.). 


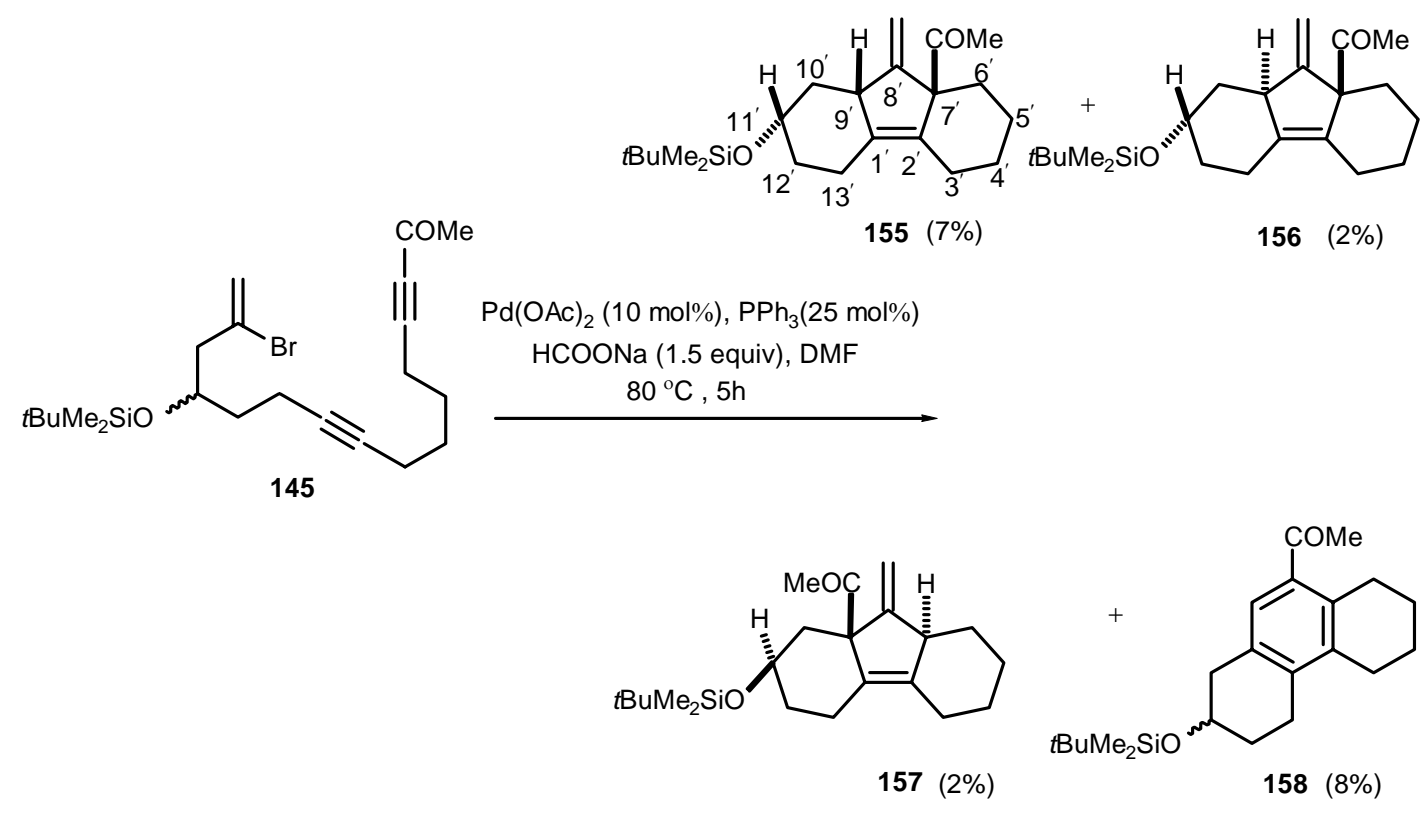

Scheme 50.

Compound 155 can be identified by one- and two-dimensional NMR techniques in addition to mass spectroscopy. Thus the structure of $\mathbf{1 5 5}$ is accurately elucidated by ${ }^{1} \mathrm{H}$ NMR, ${ }^{13} \mathrm{C}-\mathrm{NMR}$, gHSQC, H/H COSY and HMBC. The stereochemistry of $\mathbf{1 5 5}$ is determined by a series of NOE experiments. Thus, upon irradiating the angular proton (H-9'), NOE enhancements are observed on the acetyl group protons' signal and on the signal of the $\alpha$-proton of the silyloxy group (H-11'). Similarly, when the protons of the acetyl group or the $\alpha$-proton of the silyloxy group is irradiated, a NOE enhancement is observed on the signal of the angular proton. Fig 15 illustrates these NOE correlations.

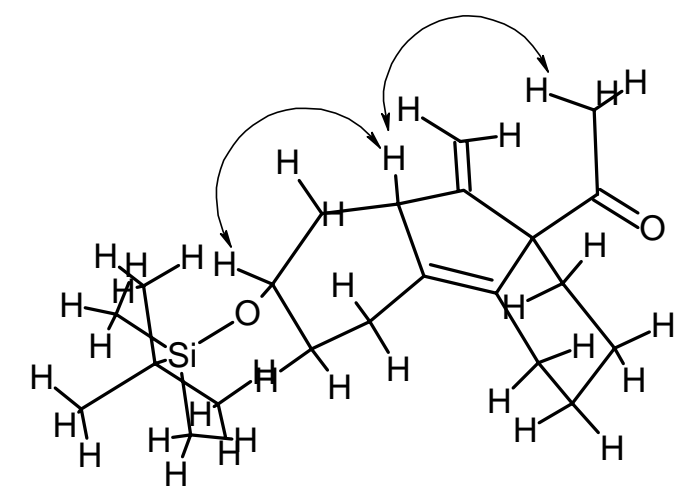

Fig 15:NOE correlations of $\mathbf{1 5 5}$ 
Similarly the structures of 156, 157 and 158 can be assigned.

The formation of 155, 156 and 157 can be explained by the same mechanisms used to explain the formation of $\mathbf{1 4 6}$. However, the last step in the formation of these compounds includes hydride ion capture. This process arises when the possibility for $\beta$-hydrogen elimination is eliminated or it becomes very difficult. The process incorporates an exchange of the halide ion with hydride, which is generated from sodium formate, at the palladium centre followed by reductive elimination, (Scheme 51.). This process had firstly been observed by R. Grigg et al and the term "hydride ion capture” was proposed to avoid using "cross coupling”. [62]

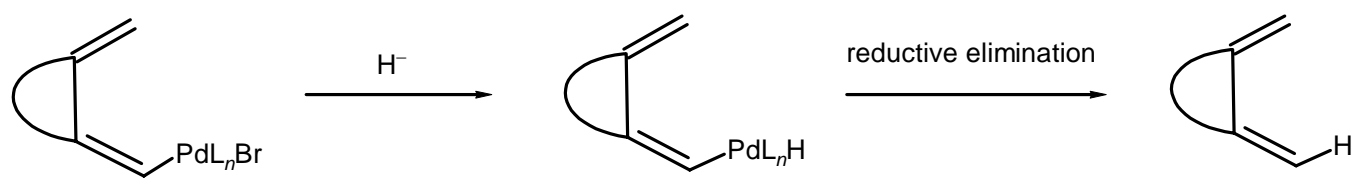

Scheme 51

Scheme 52 illustrates the formation of $\mathbf{1 5 5}$ by the first mechanism. Consequently, 1,5acyl migration yields the complex $\mathbf{1 6 0}$. The complex 160 clearly has a weak possibility to undergo $\beta$-hydrogen elimination and, therefore, it undergoes hydride ion capture process to afford the reduced compound 155 


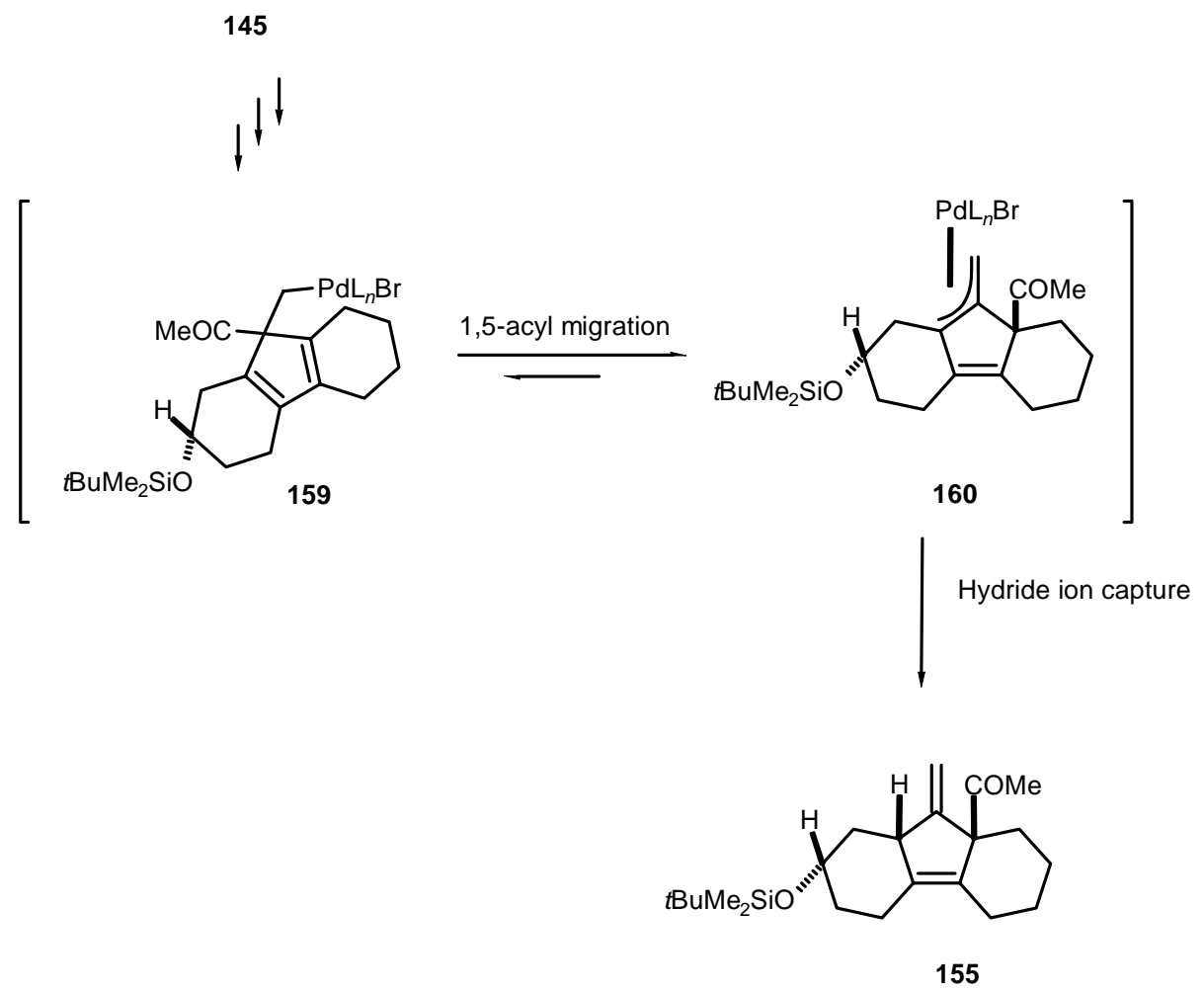

Scheme 52. 


\section{Palladium-catalyzed oligocyclization of 2-bromo-14-tetradec-1-ene-7,13-diyne}

It was mentioned earlier that palladium-catalyzed oligocyclizations of substituted terminal alkenes follow different routes depending on the nature and the pattern of the substituents on these alkenes. Scheme 14 and Scheme 33 illustrate that the cascade reaction of such precursors can occur via a sequence of either Heck-Heck-6 $\pi$ electrocyclization, (Scheme 14.), or Heck-Heck-Diels-Alder reaction, (Scheme33.), to afford in both cases tricyclic systems. However, when unsubstituted terminal alkene precursors, which might lead to three fused six-membered ring systems, such as $\mathbf{1 6 1}$, had been used, the cascade took place through a sequence of Heck reactions followed by 5exo-trig carbopalladation (Heck-Heck-5-exo-trig sequence) to afford the neopentyl like system 162 which might undergo $\gamma$-hydrogen elimination, to afford 121,( Scheme 53.). ${ }^{\text {[63] }}$<smiles>C=CCCCC(C#CCCC(C)(F)CC(=C)Br)OC</smiles>
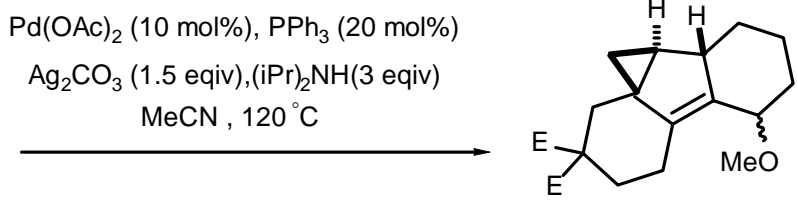

$63 \%$

121
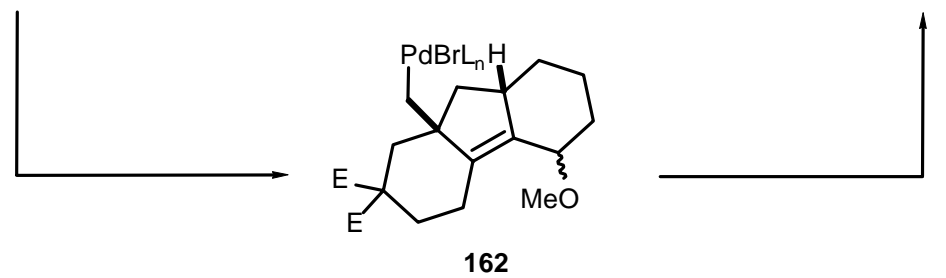

162

Scheme 53. $\mathrm{E}=\mathrm{CO}_{2} \mathrm{Me}$

A similar sequence was also observed when the $\beta$-hydrogen elimination step had been blocked by introducing a substituent $\mathrm{R}(\mathrm{Me})$ adjacent to the terminal methylene group,(Scheme 54.). ${ }^{[64]}$

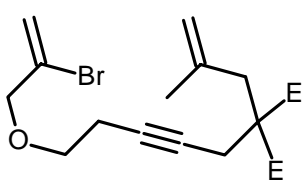

163

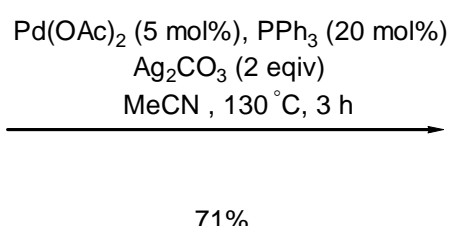

$71 \%$

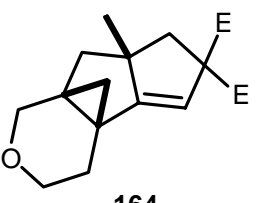

164

Scheme 54. 
When unsubstituted terminal alkyne precursors which might lead to three fused sixmemberd rings system, such as $\mathbf{1 1 5}$, had been cyclized, fulvene systems 165 were produced,( Scheme 55.). ${ }^{[34]}$<smiles>C#CCCCC#CCCC(C)(F)CC(=C)Br</smiles>

115

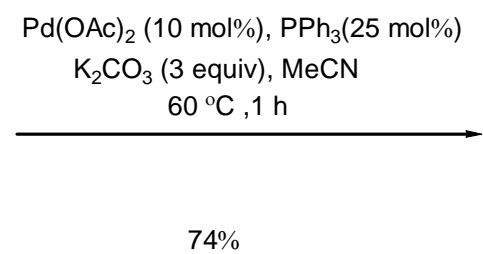

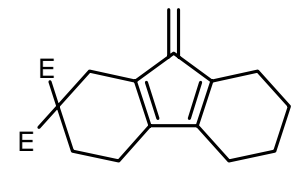

165

Scheme 55.

Even upon using carbon skeletons bearing heteroatoms, such as oxygen, the same result was obtained, (Scheme 56.). ${ }^{[34]}$<smiles>C#CCCOCC#CCCOCC(=C)Br</smiles>

166
$\mathrm{Pd}(\mathrm{OAc})_{2}(7 \mathrm{~mol} \%), \mathrm{PPh}_{3}(15 \mathrm{~mol} \%)$

$\mathrm{HCO}_{2} \mathrm{Na}, \mathrm{DMF}$

$60{ }^{\circ} \mathrm{C}, 1.5 \mathrm{~h}$

$74 \%$

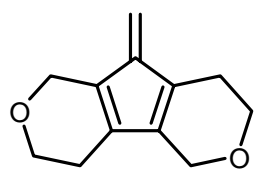

167

Scheme 56.

It has also been mentioned that when the geminal substitution (diethyl malonate group or similar groups) at the tether linking the vinylbromide with internal alkyne had been replaced by a silyloxy group, the yield of the cascade was decreased significantly. Therefore, it is interesting to examine this in the case of unsubstituted terminal alkyne. Thus, when 117 had been subjected to palladium acetate (10 mol\%) in the presence of potassium carbonate and triphenyl phosphine (25 mol\%) in acetonitrile at $60{ }^{\circ} \mathrm{C}$, the starting material was recovered and the reaction did not take place. However, when $\mathbf{1 1 7}$ is treated at $80{ }^{\circ} \mathrm{C}$ with palladium acetate $(10 \mathrm{~mol} \%)$ in the presence of triphenyl phosphine (25 mol\%) and sodium formate in DMF, the fulvene system $\mathbf{1 6 6}$ is formed in a 50\% yield, (Scheme 57.).<smiles>C#CCCCCC#CCC[C@@H](CC(=C)Br)O[Mg]C(C)(C)C</smiles>

117

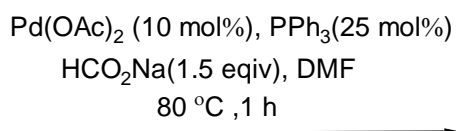

$50 \%$

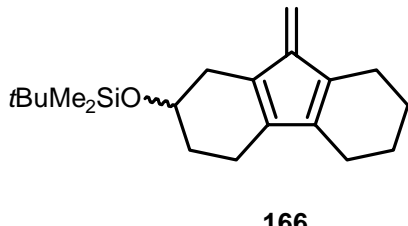

166

Scheme 57. 
Surprisingly, the fulvene can be isolated in a good yield, and the sharp decrease in the yield due to the removal of the geminal substitution is not as severe as in the previous examples.

In the light of the previous section, one mechanism involving 1,5-hydrogen migration appears as a feasible pathway for the formation of the fulvene system. Thus, after the formation of the diene system 167, 1,5-hydrogen migration will take place to form the complex 168 which undergoes a further $\beta$-hydrogen elimination to give the fulvene 166, (Scheme 58.). A mechanism involves $\beta$-hydrogen elimination from the diene system 167 was also used to describe the formation of the fulvene system. ${ }^{[34]}$

117
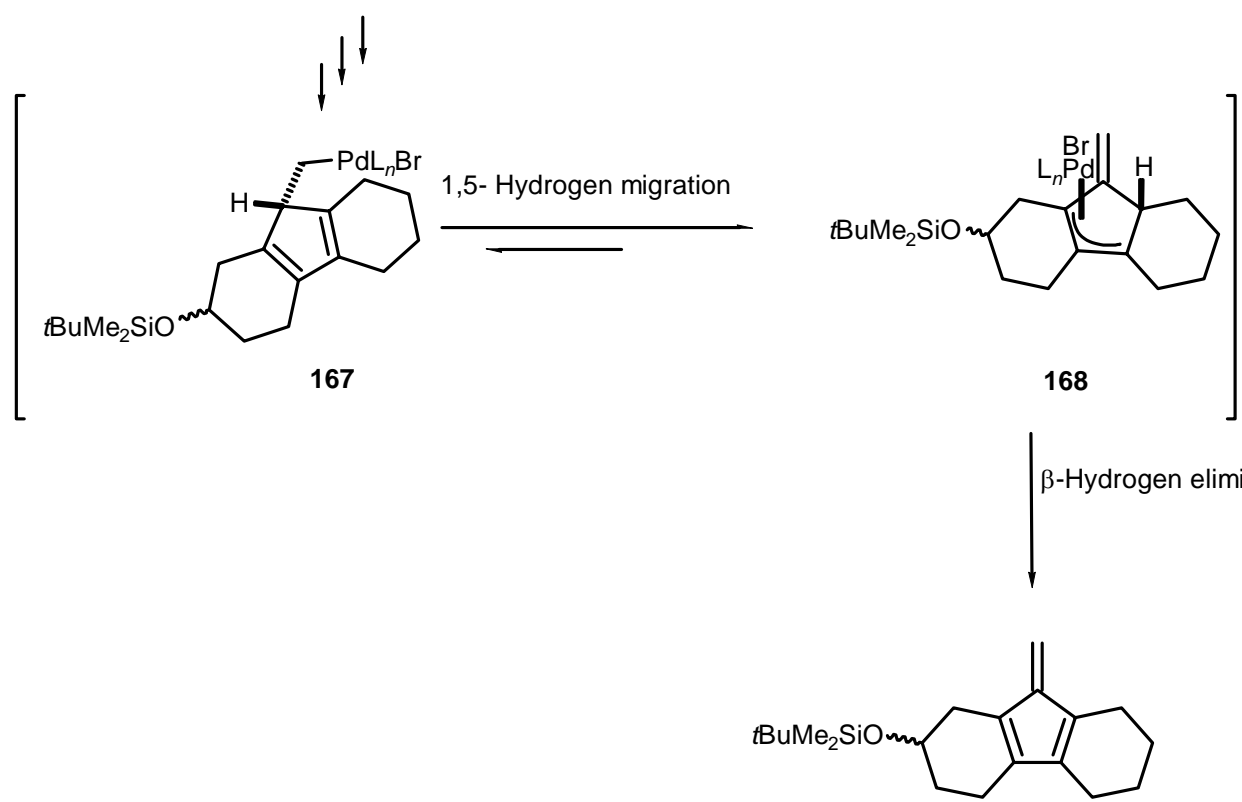

166

Scheme 58. 


\section{Summary for the Synthesis of the Precursors}

The viability of these cyclizations, and therefore their applications, depends on cost and on how easy the precursors needed for such cyclizations can be prepared. In this study, and maybe in other studies which require similar precursors, 1,7-octadiyne (60) offers a cheap, easy and general starting material for preparing such precursors. As it can be obtained from THF, (Scheme 21.), it can be considered a cheap starting material. As soon as 1,7-octadiyne is prepared, all the desired precursors can be built by a few steps which saves time and effort and makes it a general starting material for preparing these precursors, (Scheme 59.).<smiles>C=C(Br)CCC#CCCCC#C[As]</smiles>

79

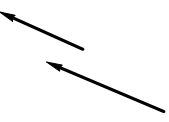

133<smiles>C#CCCCCC#CCCOCC(=C)Br</smiles>
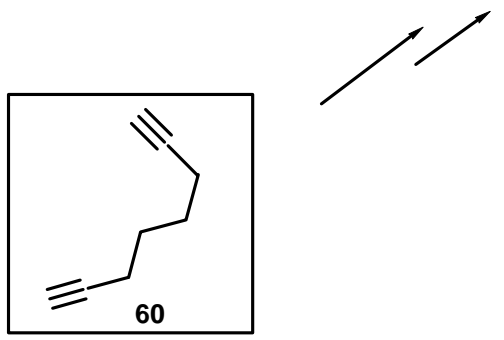<smiles>C#CCCCCC#CCCC(F)(F)CC(=C)Br</smiles>

115
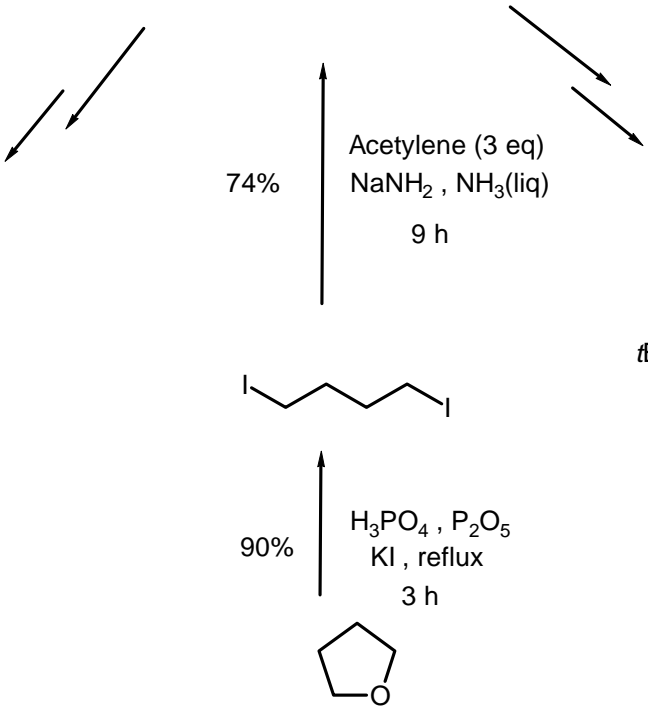

63<smiles></smiles>

117

Scheme 59. 
Alternative approaches which start from different starting material are not as efficient as the approaches which start from 1,7-octadiyne. Thus, for example, synthesis of $\mathbf{1 1 5}$ starting from other starting materials, requires extra steps in protecting and de-protecting and it also requires starting materials which are either laborious to synthesize or expensive to buy, (Scheme 60.). ${ }^{[33]}$ Other examples were shown in the previous sections which makes 1,7-octadiyne a good choice for synthesizing these precursors. 
<smiles>C#CCCCCO</smiles>

83
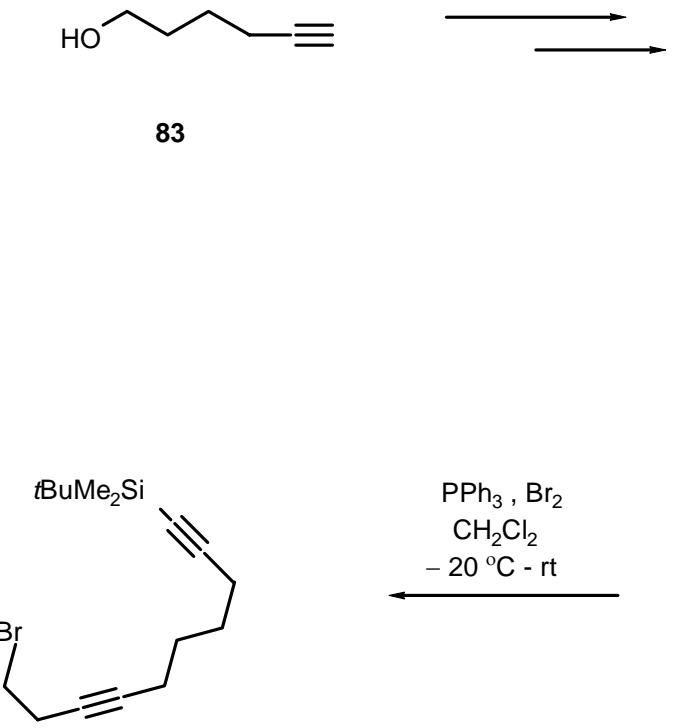

170

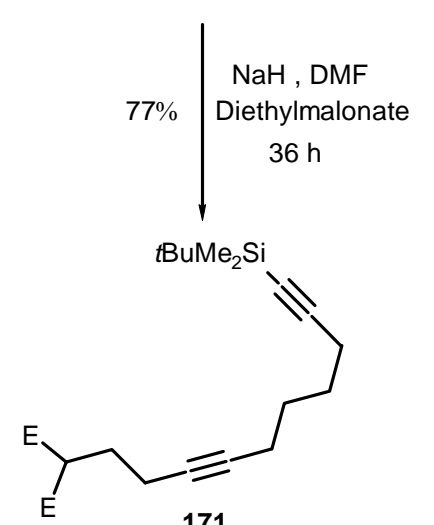

171

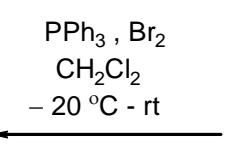

$80 \%$

$\mathrm{NaH}, \mathrm{DME}$

2,3-Dibromopropene $24 \mathrm{~h}$

$48 \%$

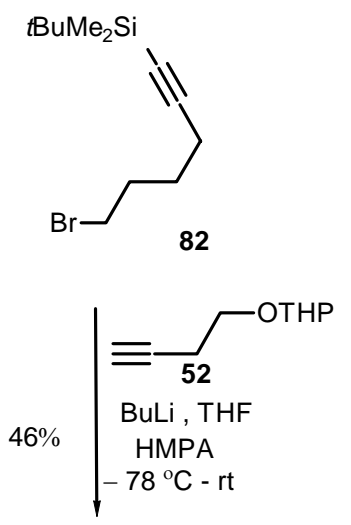

tBuMe $\mathrm{Bi}_{2}$

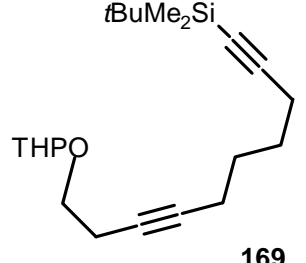

169

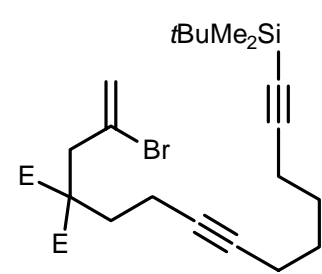

77

$86 \% \quad \begin{gathered}\mathrm{Bu}_{4} \mathrm{NF}, \mathrm{THF} \\ 60{ }^{\circ} \mathrm{C}, 4 \mathrm{~h}\end{gathered}$<smiles>C#CCCCCC#CCCC(F)(F)CC(=C)Br</smiles>

115

Scheme 60. $\mathrm{E}=\mathrm{CO}_{2} \mathrm{Me}$ 


\section{Summary of the mechanistic aspects.}

As mentioned earlier, there are several mechanistic pathways via which palladium catalyzed oligocyclization of terminal alkene precursors can take place. The route that the cascade may follow can be determined by the type and the pattern of the substitution at the terminal alkenes of these precursors. However, in the case of the terminal alkyne precursors which might lead to formation of three fused six-memberd rings, there is only one mechanistic pathway via which the oligocyclization might take place. This pathway involves two Heck reactions followed by a 5-exo-trig carbapalladation (Heck-Heck-5exo-trig sequence). This stems from the fact that cascade's outcome of such precursors depends on the substituent type at the terminal alkyne and this route provides the only pathway by which the role of these substituents can be rationalized. Thus after two Heck reactions the cascade will undergo 5-exo-trig carbapalladation to afford the neopentyllike system 173, Scheme 61 . Providing that $6 \pi$-electrocyclization took place, the reaction outcome would always be a tricyclic system with three fused six-membered rings. In fact, this will not be the case when the terminal triple bond bears an electron-withdrawing group such as an ester group is cyclized. Furthermore, the formation of the tetracyclic system 177, which clearly formed via 5-exo-trig carbametallation, in the later case will, in fact, eliminate any possibility for 6-endo-trig carbapalladation because there is no reasonable reason why the cascade would follow 6-endo-trig mode in one case while it would follow 5-exo-trig mode in another, bearing in mind that the determining factor for either mode is the geometry of the intermediate triene 172. Thus, after a 5-exo-trig carbapalladation, a further 3-exo-trig carbapalladation will take place to offer the complex 174. At this stage there are two possibilities, depending on the substituent $\mathrm{R}$, via which the cascade might continue its way. Thus, when $\mathrm{R}$ is an electron-donating group, it will undergo cyclopropyl ring opening to form the three fused six-membered ring system 178 which undergoes $\beta$-hydrogen elimination to afford the thermodynamically stable bisannelated benzene 179. When $\mathrm{R}$ is an electron-withdrawing group, such as an ester, cyclopropylhomoallyl rearrangement will take place to offer the diene system $\mathbf{1 7 5}$, which undergoes a further 3-exo-trig carbapalladation followed by $\beta$-hydrogen elimination to afford the tetracyclic system 179. On the other hand, in the later case, when $\mathrm{R}$ is a group which is capable of migration or elimination such as acetyl or hydrogen, the $\mathrm{R}$ group at 
diene system 175 might undergo 1,5-migration or $\beta$-carbon elimination to offer fulvene $\mathbf{1 8 1}$ systems or fulvene-like $\mathbf{1 8 2}$ systems. Scheme 61 illustrates these considerations.

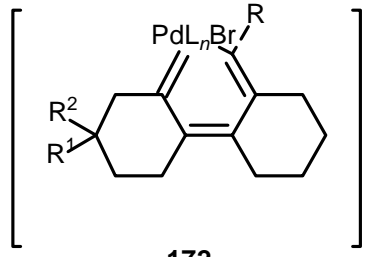

172

\section{5-exo-trig carbopalladation}

173 3-exo-trig carbopalladation<smiles>[R]C1([2H])CCC2=C(C1)C1=C(CCCC1)C2([R])CBr</smiles>
cyclopropyl to homoallylrearrangement $\mathrm{R}$ : electron-withdrawing 175<smiles>[R]C=C=C</smiles>
3-exo-trig carbopalladation

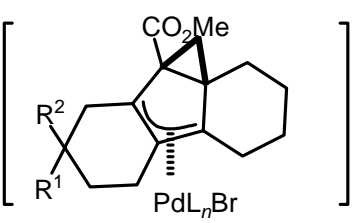

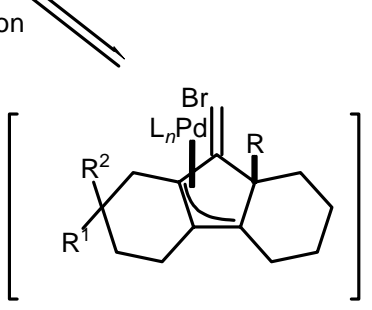<smiles>[R]C1=C2CCCCC23CC([R])([R])CC(=C3CC)C1Br</smiles>

176 $\beta$-Hydrogen elimination<smiles>[R]C1([R])CCC2=C(C1)C(=C)C1=C2CCCC1</smiles>

181

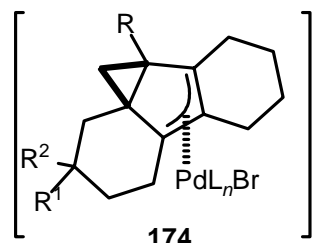
174 R : electron-donating

178<smiles>[R]C1([R])C=C2C(=C3CCCCC34C(C)(C)C24C)CC1</smiles>

177<smiles>[R]C1([R])C=C2C(=C)C3([R])CCCCC3=C2CC1</smiles>

182

Scheme 61. 


\section{Experimental Part}

\section{General Notes}

The synthesized compounds were characterized by the following conditions and instruments.-IR: Bruker IFS 66, Perkin-Elmer 298.- ${ }^{1}$ H-NMR: Bruker AM 250 (250 MHz), Varian INOVA-500 (500 MHz), Varian INOVA-600 (600 MHz), $\delta(p p m)=0$ for tetramethylsilane , 7.26 for chloroform. The signals were characterized : $\mathrm{s}=$ singlet, bs = broad singlet, $\mathrm{d}=$ doublet, $\mathrm{t}=$ triplet, $\mathrm{q}=$ quartet, $\mathrm{dd}=$ double doublet, $\mathrm{ddd}=$ double of doublet, $\mathrm{dt}=$ double of triplet, $\mathrm{tt}=$ triple of triplet, $\mathrm{dq}=$ double of quartet, $\mathrm{tq}=$ triple of quartet, $\mathrm{m}=$ multiplet, $J \mathrm{ax}-\mathrm{ax}=$ Jaxial-axial, Jax-eq $=$ Jaxial-equatorial, Jeq-eq $=$ Jequatorial-equatorial, THP-H $=$ tetrahydropyranyl proton, TBDMS-H $=$ tertbutyldimethylsilyl proton. ${ }^{13} \mathrm{C}-\mathrm{NMR}$ Bruker AM 250 (62.5 MHz), Varian INOVA-500 (125.7 MHz), Varian INOVA-600 (150.8 MHz), $\delta(\mathrm{ppm})=0$ for tetramethylsilane, 77.0 for chloroform-d. ${ }^{*}=$ assignment is interchangeable. The multiplicities of ${ }^{13} \mathrm{C}-\mathrm{NMR}$ signals were determined with help of either DEPT-(Distortionless Enhancement by Polarization Transfer) or APT-(Attached Proton Test) and are designated as follows: $\mathrm{CH}_{3}, \mathrm{CH}=(+)(\mathrm{DEPT}$ and APT $), \mathrm{CH}_{2}=(-),($ DEPT and APT $), \quad$ quaternary $\mathrm{C}=(-)$ (APT), $\mathrm{C}_{\text {quart }}$ (DEPT), TBDMS-C = tert-butyldimethylsilyl carbon THP-C = tetrahydropyranyl carbon, rot = rotomer.-MS: Varian MAT CH 7, MAT 731.-HRMS: Varian MAT 311 A.-Microanalysis: Mikroanalytisches Laboratorium des Instituts für Organische Chemie der Georg-August-Universität Göttingen.-Column chromatography was performed on Merck Silica gel 60 (0.063-0.200 mm).- Thin layer chromatography : Macherey-Nagel Alugram G/UV $\mathrm{UV}_{254} 0.25 \mathrm{~mm}$ silica gel with fluorescent indicator.Developer: molybdenum phosphoric acid solution (10\% in ethanol).-All operations were performed under Nitrogen or Argon atmosphere.-Solvents were purified and dried according to the conventional methods. The following abbreviations have been used: DME = 1,2-dimethoxyethane, DMPU = 1,3-dimethyltetrahydro-2(1H)-pyrimidinon, HMPA = hexamethylphosphoramide, DMF = dimethylformamide. 


\section{General procedures}

General Procedure for Alkylation of Alkyne with Alkylbromide (GP1)

To a solution of $\mathrm{n}$ - butyllithium (hexane solution) in $20 \mathrm{ml}$ of dry THF is added at -78 ${ }^{\circ} \mathrm{C}$, slowly, the alkyne (10 mmol). After stirring for $15 \mathrm{~min}$, HMPA and a solution of alkylbromide $(1.2 \mathrm{mmol})$ in $5 \mathrm{ml}$ THF are added to the alkyne mixture and stirring is continued for $1 \mathrm{~h}$ at $-78{ }^{\circ} \mathrm{C}$ and $24 \mathrm{~h}$ at room temperature. The reaction mixture is then quenched with saturated solution of ammonium chloride and extracted with diethyl ether $(3 \times 20 \mathrm{ml})$. After drying over magnesium sulfate, the ether is evaporated and the residue is eluted with pentane-ether over silica gel using column chromatography.

General Procedure for Brominating of Tetrahydropyranyl Ether (GP2).

Bromine (40 mmol) is added, dropwise, into a solution of triphenylphosphine (42 mmol) in dichloromethane at $-20{ }^{\circ} \mathrm{C}$. After stirring for $30 \mathrm{~min}$, tetrahydropyranylether (12 mmol) is added to the resulting white suspension .The reaction mixture is allowed to warm to room temperature and stirring is continued for addional $12 \mathrm{~h}$. The reaction mixture is then concentrated and the residue is treated with pentane $(3000 \mathrm{ml})$. The precipitating triphenylphosphine oxide is filtered and the pentane is evaporated. The residue is purified using column chromatography (silica gel, pentane-diethyl ether as eluent).

General Procedure for Dialkyl malonate Coupling with Alkyl halide and Mesylate (GP3).

A. Coupling with alkyl halides

Dialkyl malonate (10 mmol) is added, dropwise, to a suspension of sodium hydride ( $0.4 \mathrm{~g}$ $60 \%$ oil suspension, $10 \mathrm{mmol}$ ) in dimethylformamide DMF $20 \mathrm{ml}$. After the addition, the mixture is warmed gently (at $\sim 50{ }^{\circ} \mathrm{C}$ ) till it becomes a clear solution and all the suspension dissolves. The alkyl halide is added to the resulting clear solution and stirring is continued for $36 \mathrm{~h}$ at room temperature. The reaction mixture was then poured into 70 $\mathrm{ml}$ of water and extracted with $(3 \times 70 \mathrm{ml})$ diethyl ether .The combined ether layers are washed with brine, dried over $\mathrm{MgSO}_{4}$ and concentrated. The residue is purified using column chromatography (silica gel, pentane-diethyl ether as eluent). 


\section{B. Coupling with Mesylate $e^{[65]}$}

Dialkyl malonate $(15 \mathrm{mmol})$ is added at $50{ }^{\circ} \mathrm{C}$, dropwise, into a suspension of sodium hydride (0.6 g 60\% oil suspension,15 mmol) in DMF (50ml). The resulting clear solution, is added to a solution of myslate (6.11 mmol), potassium iodide (KI)(6.11 mmol), in THF and the reaction mixture was refluxed at $70{ }^{\circ} \mathrm{C}$ for $24 \mathrm{~h}$. After cooling, the mixture is treated with saturated solution of ammonium chloride and extracted with $(4 \times 70 \mathrm{ml})$ diethyl ether. The combined ether layers are washed with brine, dried over $\mathrm{MgSO}_{4}$ and concentrated .The residue is distilled using kugelrohr distillation and further purified by column chromatography (silica gel and pentane-diethyl ether as eluent).

\section{General Procedure for Tin Catalyzed Coupling of Acetals with Allylic Bromide(GP4)}

To a suspension of tin powder in diethyl ether /water mixture $(5: 2 \mathrm{v} / \mathrm{v})$ is added, successively, 2,3-dibromopropene (57), 40 drops of $48 \% \mathrm{HBr}$ and the acetal. The mixture is vigorously stirred for 5-6 days at room temperature. The reaction mixture is then diluted with $150 \mathrm{ml}$ of water and $150 \mathrm{ml}$ of diethyl ether and extracted thoroughly with $(10 \times 100 \mathrm{ml})$ of diethyl ether. The combined ether layers are dried over $\mathrm{MgSO}_{4}$, and concentrated. The produced alcohol is immediately purified using column chromatography (silica gel and pentane-diethyl ether as eluent).

General Procedure for Protecting of Alcohols with tert-Butyldimethylsilyl chloride (GP5) tert-butyldimethylsilyl chloride $(8 \mathrm{mmol})$ is added to a solution of the alcohol (5.6 mmol) and imidazole $(20 \mathrm{mmol})$ in DMF $(20 \mathrm{ml})$ at $55{ }^{\circ} \mathrm{C}$. After stirring at $55{ }^{\circ} \mathrm{C}$ for $12 \mathrm{~h}$, the reaction mixture is poured into $70 \mathrm{ml}$ of water and extracted with $(3 \times 40 \mathrm{ml})$ of diethyl ether. The combined ether layers are dried over $\mathrm{MgSO}_{4}$, and concentrated. The residue is purified using column chromatography (silica gel and pentane-diethyl ether as eluent). 
General Procedure for Terminal Alkyne Coupling with Anhydride or Methylchloroformate (GP6).

A solution of LDA (4.2 mmol) (lithium diisopropyl amine) in THF (10 ml) is added -78 ${ }^{\circ} \mathrm{C}$, dropwise, to a solution of the teminal alkyne $(3.8 \mathrm{mmol})$ in THF $(10 \mathrm{ml})$ at $-78{ }^{\circ} \mathrm{C}$. After stirring for 30 min, HMPA and acetyl anhydride or chloromethylformate are added to the reaction mixture and stirring is continued for $1 \mathrm{~h}$ at $-78{ }^{\circ} \mathrm{C}$ and $2 \mathrm{~h}$ at room temperature. The resulting reaction mixture is then quenched with saturated solution of ammonium chloride and extracted with $(3 \times 50 \mathrm{ml})$ diethyl ether. The combined ether layers are dried $\left(\mathrm{MgSO}_{4}\right)$, concentrated, and the residue is purified by using column chromatography (silica gel and pentane-diethyl ether as eluent).

General Procedure for Brominating a Terminal Alkyne with B-Bromo-9borabicyclo[3.3.1]nonane (B-Br-9-BBN)(GP7)

The alkyne $(3.3 \mathrm{mmol})$ is added to a solution of B-Br-9-BBN $(7.3 \mathrm{mmol})$ in a $25 \mathrm{ml}$ dichloromethane (prepared by adding a $7.3 \mathrm{ml}$ of $1 \mathrm{M}$ commercially available solution of B-Br-9-BBN in dichloromethane to a $17.7 \mathrm{ml}$ dichloromethane) under argon atmosphere and at $0{ }^{\circ} \mathrm{C}$. After stirring for $3 \mathrm{~h}$ at $0{ }^{\circ} \mathrm{C}, 2 \mathrm{ml}$ of glacial acetic acid is added and stirring is continued for additional $1 \mathrm{~h}$ before adding $30 \mathrm{ml}$ of $3 \mathrm{M}$ aqueous sodium hydroxide followed by dropwise addition of $6 \mathrm{ml}$ of 30\% hydrogen peroxide. The reaction mixture is stirred for further $1 \mathrm{~h}$ and the resulting two layers are separated. The aqueous layer is extracted with $(3 \times 40 \mathrm{ml})$ dichlomethane and the combined organic layers are washed sequentially with $100 \mathrm{ml}$ of water, $100 \mathrm{ml}$ of saturated solution of sodium bicarbonate, and $100 \mathrm{ml}$ of water. The combined organic layers are then dried $\left(\mathrm{MgSO}_{4}\right)$, concentrated, and the residue is eluted with pentane from a column of silica gel.

General Procedure for Palladium Oligocyclizations (Heck reaction) (GP8).

The palladium catalyzed oligocyclization is induced by different reaction conditions which are illustrated by the following methods:

\section{Method A;}

palladium acetate (0.1 equiv) is added at $60{ }^{\circ} \mathrm{C}$ to a degassed mixture, place in a Pyrex ${ }^{\circledR}$ crucible, of triphenylphosphine (0.25 equiv), potassium carbonate (2.5 equiv), and 2- 
bromoalk-1-enediyene precursor (1 equiv) in acetonitrile. After stirring for 1 to $12 \mathrm{~h}$ at 60 ${ }^{\circ} \mathrm{C}$, the reaction mixture is allowed to cool to room temperature, filtered over two layers of celita and charcoal and concentrated. The residue is purified by thick layer chromatography (TLC) using $20 \times 20 \mathrm{~cm}$ plates coated with silica gel $60 \mathrm{PF}_{254}$ containing $2.5 \% \mathrm{CaSO}_{4}$.

\section{Method B;}

Palladium acetate ( 0.1 equiv) is added at $80{ }^{\circ} \mathrm{C}$ to a degassed mixture, placed in a Pyrex ${ }^{\circledR}$ crucible, of triphenylphosphine (0.25 equiv), sodium formate (1.2 equiv), and the 2bromoalk-1-enediyene precursor (1 equiv) in DMF. After stirring from 1 to $12 \mathrm{~h}$ at $80{ }^{\circ} \mathrm{C}$, the reaction mixture is poured into $30 \mathrm{ml}$ of water and extracted $(3 \times 20 \mathrm{ml})$ with diethyl ether. The combined ether layers are dried $\left(\mathrm{MgSO}_{4}\right)$, concentrated and the residue is purified by thick layer chromatography (TLC) using $20 \times 20 \mathrm{~cm}$ plates coated with silica gel $60 \mathrm{PF}_{254}$ containing 2.5\% $\mathrm{CaSO}_{4}$. 


\section{Synthesis of the precursors}

1-phenyl-10-tetrahydro-2H-pyranyloxy-1,7-decadiyne (53)

According to GP1, 1.4 g (10 mmol) of 2-(3-butynyloxy)tetrahydro-2H-pyran (52) in $5 \mathrm{ml}$ THF was added at $-78{ }^{\circ} \mathrm{C}$ to a solution of $5 \mathrm{ml}(11 \mathrm{mmol})$ of n-butyl lithium (2.3 $\mathrm{M}$ in

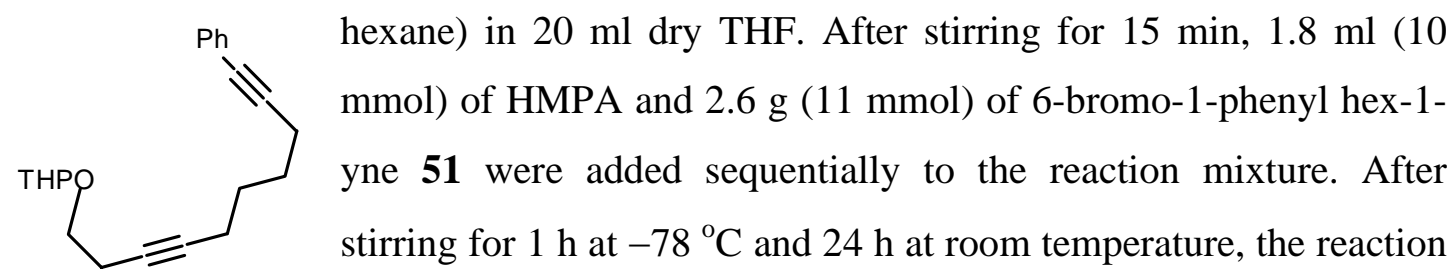
mixture was quenched with $40 \mathrm{ml}$ of saturated solution of ammonium chloride, the organic layer was separated, and the aqueous layer was extracted with $(3 \times 30 \mathrm{ml})$ of diethyl ether. The combined organic layers were dried $\left(\mathrm{MgSO}_{4}\right)$,concentrated and the residue was purified by column chromatograph (60g silica gel and 20:1 pentane/diethyl ether) to afford a colorless liquid $1.5 \mathrm{~g}(48 \%) .\left(\mathrm{R}_{\mathrm{f}}=0.13\right.$, 20:1 pentane/diethyl ether).-IR (Film) $: v=3057 \mathrm{~cm}^{-1}$, 2945, 2231, 1739, 1598, 1490, 1439, 1382, 1326, 1120, 1033, 758, 693.- ${ }^{1} \mathrm{H}-\mathrm{NMR}\left(250 \mathrm{MHz}, \mathrm{CDCl}_{3}\right.$ ) $: \delta=1.50-1.80$ ( m, 10 H, 6 H, THP-H, 4 H, 4( 5)- H), 2.18 - 2.24 (m, 2 H, 3-H), $2.39-2.50$ (m, 4 H, 2-H, 6-H), 3.47 - 3.57 (m, 2H,THP-H), 3.75-3.85 (m, 2 H, 10-H), 4.64 (m, 1 H, THP-H), $7.19-7.40$ (m , 5 H , phenyl-H). $-{ }^{13} \mathrm{C}-\mathrm{NMR}\left(62.5 \mathrm{MHz}, \mathrm{CDCl}_{3}, \mathrm{DEPT}\right): \delta=18.31$ (-, C-6) $18.96(-, \mathrm{C}-5$ ) 19.40 (-, C-9), 20.20 (- , THP-C), 25.40 (- , THP-C), 27.76 (-, C-4*) , 28.05 (-, C-5*), 30.54 (-, THP-C), 62.16 (-, THP-C) , 66.16 (-, C-10), 77.00 ( $\left.\mathrm{C}_{\text {quart }}, \mathrm{C}-8\right), 79.17$ ( $\mathrm{C}_{\text {quart }}$, C-2), 80.76 ( $\left.\mathrm{C}_{\text {quart }}, \mathrm{C}-7\right), 89.86$ ( $\mathrm{C}_{\text {quart, }}$ C-1), 98.69 (+, THP-C), 123.90 ( $\mathrm{C}_{\text {quart }}$ phenyl-C), 127.44 (+, o- phenyl-C), 128.15 (+, m-phenyl-C), 131.50 (+, p-phenyl-C) .- MS (EI, 70

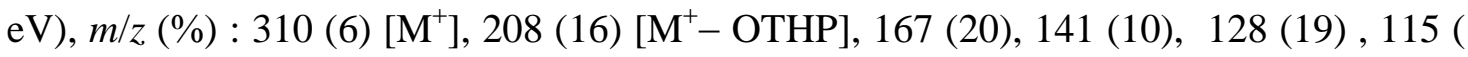
41) $\left[\mathrm{C}_{9} \mathrm{H}_{7}^{+}\right], 85$ (100) $\left[\mathrm{C}_{5} \mathrm{H}_{9} \mathrm{O}^{+}\right], 57$ (16), 41 (24) . - $\mathrm{C}_{21} \mathrm{H}_{26} \mathrm{O}_{2}(310.2)$ 
1-(10'-bromo-1',7'-decadiynyl)benzene (54)

According to GP2, 4g (13 mmol) of 1-phenyl-10-tetrahydro-2H-pyranyloxy-1,7decadiyne(53) was added at $-20{ }^{\circ} \mathrm{C}$ to a white suspension of triphenylphosphine dibromide, which had been prepared by dropwise addition of $6.4 \mathrm{~g}$
$(40 \mathrm{mmol})$ of bromine to a solution of $9.3 \mathrm{~g}(35.5 \mathrm{mmol})$
triphenylphosphine in dichloromethane at $-20{ }^{\circ} \mathrm{C}$ and stirring for 30
min, and stirring was continued for $20 \mathrm{~h}$ at room temperature. After working up, as described in GP2, the resulting residue was purified using column chromatography (50 g of silica gel, 20:1 pentane/diethyl ether) to afford $2.8 \mathrm{~g}$ (75\%) of a yellow oil. $\left(\mathrm{R}_{\mathrm{f}}=0.63,20: 1\right.$ pentane/diethyl ether).-IR (Film): $v=3055 \mathrm{~cm}^{-1}, 2925,2361$, 2338, 1734, 1598, 1490, 1439, 1271, 1212, 757, 692.- ${ }^{1} \mathrm{H}-\mathrm{NMR}\left(250 \mathrm{MHz}, \mathrm{CDCl}_{3}\right): \delta=$ $1.63-1.75$ (m, 4 H, 4' (5')-H), 2.22 (m, 2 H, 3'-H), 2.44 (t, $\left.{ }^{3} J=6.6 \mathrm{~Hz}, 66^{\prime}-\mathrm{H}\right), 2.72\left(\mathrm{dt},{ }^{3} J\right.$ $\left.=7.3,{ }^{2} J=2.3 \mathrm{~Hz}, 2 \mathrm{H}, 9^{\prime}-\mathrm{H}\right), 3.44\left(\mathrm{t},{ }^{3} J=6.6 \mathrm{~Hz}, 2 \mathrm{H}, 10^{\prime}-\mathrm{H}\right), 7.26-7.41$ (m, $5 \mathrm{H}$, phenyl-H).- ${ }^{13} \mathrm{C}-\mathrm{NMR}$ ( $\left.62.5 \mathrm{MHz}, \mathrm{CDCl}_{3}, \mathrm{DEPT}\right): \delta=18.27$ (-, C-6'), 18.94 (-, C-3'), 23.32 (-, C-9'), $27.74\left(-, \mathrm{C}^{4^{\prime *}}\right), 27.87\left(-, \mathrm{C}^{\prime \prime *}\right), 30.27$ (-, C-10') , 77.29 (C quart, $\left.\mathrm{C}-8^{\prime}\right)$, 80.85 ( $\left.\mathrm{C}_{\text {quart }}, \mathrm{C}-7^{\prime}\right), 82.11$ ( $\left.\mathrm{C}_{\text {quart }}, \mathrm{C}^{2}{ }^{\prime}\right), 89.81$ ( $\left.\mathrm{C}_{\text {quart }}, \mathrm{C}-1^{\prime}\right), 123.90$ ( $\mathrm{C}_{\text {quart }}$, phenyl-C), 127.53 (+, o-phenyl-C), 128.18 (+, m-phenyl-C), 131.51 (+, p- phenyl-C). - MS (EI, 70

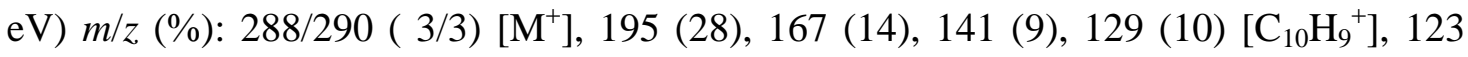
(100), 115 (48) $\left[\mathrm{C}_{9} \mathrm{H}_{7}^{+}\right], 91$ (25) $\left[\mathrm{C}_{7} \mathrm{H}_{7}^{+}\right], 67$ (17), 41 (14). $-\mathrm{C}_{16} \mathrm{H}_{17} \mathrm{Br}(289.06)$

Diethyl2-(10'-phenyl-3' ,9' -decadiynyl)malonate (55)

According to GP3A, $1.6 \mathrm{~g}$ (10 mmol) of diethyl malonate was

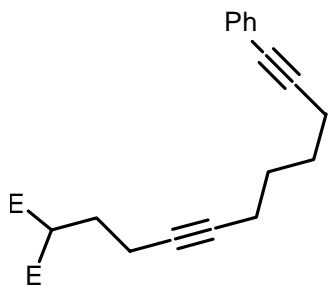
added, dropwise, to a suspension of $0.4 \mathrm{~g}(10 \mathrm{mmol})$ of sodium hydride ( $60 \%$ oil suspension) in $20 \mathrm{ml}$ of dry DM. After the suspension had dissolved (warming to $\sim 50{ }^{\circ} \mathrm{C}$ if necessary), $2.5 \mathrm{~g}$ (8.6 mmol) of 1-(10'-bromo-1',7'-decadiynyl)benzene (54) was added and stirring was continued for $36 \mathrm{~h}$ at room temperature. The resulting residue, after working up as described in GP3, was purified by column chromatography (100 g of 
silica gel , 1:10 pentane/diethyl ether) to afford $2 \mathrm{~g}$ of a colorless oil. $\left(\mathrm{R}_{\mathrm{f}}=0.28,10: 1\right.$ pentane/diethyl ether).-IR (Film) $: v=3059 \mathrm{~cm}^{-1}, 2983$, 2862, 2839, 1753, 1730, 1599, 1491, 1442, 1246, 1151, 1049, 1025, 758, 693.- ${ }^{1} \mathrm{H}-\mathrm{NMR}\left(250 \mathrm{MHz}, \mathrm{CDCl}_{3}\right): \delta=1.25$ (t, ${ }^{3} \mathrm{~J}=7 \mathrm{H}, 6 \mathrm{H}, \mathrm{COOCH}_{2} \mathrm{CH}_{3}$ ), $1.65-1.70$ (m, 4 H, 6', 7'-H), 2.05 (m, 2 H, 1'-H), 2.18 2.24 (m, 4 H, 2' (5')-H), 2.42 (t, ${ }^{3} J=6.5 \mathrm{~Hz}, 2$ H, 8'-H), 3.55 (t, $\left.{ }^{3} \mathrm{~J}=6 \mathrm{~Hz}, 1 \mathrm{H}, 2-\mathrm{H}\right)$, $4.18\left(\mathrm{q},{ }^{3} \mathrm{~J}=6 \mathrm{~Hz}, 4 \mathrm{H}, \mathrm{COOCH}_{2} \mathrm{CH}_{3}\right), 7.24-7.40$ (m, $5 \mathrm{H}$, phenyl-H). ${ }^{13} \mathrm{C}-\mathrm{NMR}(62.5$ $\left.\mathrm{MHz}, \mathrm{CDCl}_{3}, \mathrm{DEPT}\right): \delta=14.04\left(+, \mathrm{COOCH}_{2} \mathrm{CH}_{3}\right), 16.74$ (-, C-2'), 18.28 (- , C-5'), 18.96 (-, C-8'), 27.37 (-, C-1'), 27.97 (-, C-6 $\left.{ }^{\prime *}\right), 28.06$ (-, C-7**), 50.58 (+, C-2), 61.39 (-, $\left.\mathrm{COOCH}_{2} \mathrm{CH}_{3}\right), 78.33$ (C $\mathrm{C}_{\text {quart }}, \mathrm{C}^{-3}$ '), 80.79 (C quart, C-4'), 81.22 (C $\left.\mathrm{C}_{\text {quat }}, \mathrm{C}-9^{\prime}\right), 89.83$ ( $\mathrm{C}_{\text {quart }}, \mathrm{C}-10$ '), 123.90 ( $\mathrm{C}_{\text {quart, }}$ phenyl-c), 127.49 (+, o-phenyl-C), 128.14 (+, m-phenyl-C), 131.50 (+, p-phenyl-C), $169.2\left(\mathrm{C}_{\text {quart, }} \mathrm{COOCH}_{2} \mathrm{CH}_{3}\right)$. -MS (DCI, $\left.\mathrm{NH}_{3}, 70 \mathrm{eV}\right) \mathrm{m} / \mathrm{z}(\%)$ : $754(2)\left[2 \mathrm{M}+\mathrm{NH}_{4}^{+}\right], 386\left[\mathrm{M}+\mathrm{NH}_{4}^{+}\right] .-\mathrm{C}_{23} \mathrm{H}_{28} \mathrm{O}_{4}(368)$

Diethyl2-(2' '-bromoallyl)-2-(10'-phenyl-3',9'-decadiynyl)malonate (48)<smiles>C=C(Br)CC(F)(F)CC#CCCCCC#Cc1ccccc1</smiles>

To a suspension of $0.32 \mathrm{~g}$ ( $8 \mathrm{mmol})$ of sodium hydride $(60 \%$ oil suspension) in $15 \mathrm{ml}$ of DME (1,2-dimethoxyethane) was added, dropwisely, a solution of $2.2 \mathrm{~g}$ (5.9mmol) of diethyl 2-(10'-phenyl3',9'-decadiynyl)malonate (55) in $5 \mathrm{ml}$ of DME. After warming for $30 \mathrm{~min}$ at $\sim 50{ }^{\circ} \mathrm{C}, 2.1 \mathrm{~g}$ (10.5 mmol) of 2,3-dibromopropene was added and the reaction was stirred for $30 \mathrm{~h}$ at room temperature. The reaction mixture was then poured into $50 \mathrm{ml}$ of water, the two layers were separated, and the aqueous layer was extracted with $(3 \times 50 \mathrm{ml})$ diethyl ethyl ether. the combined ether layers were dried $\left(\mathrm{MgSO}_{4}\right)$, concentrated and the residue was purified by column chromatography (100 g silica gel , 20:1 pentane/diethyl ether) to afford $1.3 \mathrm{~g}(44 \%)$ of a colorless oil . $\left(\mathrm{R}_{\mathrm{f}}=0.12\right.$, 20:1 pentane/diethyl ether).-IR (Film) $: v=3056 \mathrm{~cm}^{-1}, 2982,2943,2839,2230,1725$, 1625, 1491, 1445, 1367, 1270, 1242, 1186, 1024, 898, 759, 737, 693.- ${ }^{1}$ H-NMR ( 250 $\left.\mathrm{MHz}, \mathrm{CDCl}_{3}\right): \delta=1.25$ (t, $\left.{ }^{3} \mathrm{~J}=7 \mathrm{~Hz}, 6 \mathrm{H}, \mathrm{COOCH}_{2} \mathrm{CH}_{3}\right), 1.65$ (m, 4H, 6'(7')-H), 2.12 2.25 (m, 6 H, 1' (5' 8') - H), $2.42\left(\mathrm{t},{ }^{3} \mathrm{~J}=6.6 \mathrm{~Hz}, 2 \mathrm{H}, 2^{\prime}-\mathrm{H}\right), 3.16$ (s , $\left.2 \mathrm{H}, 1^{\prime \prime}-\mathrm{H}\right), 4.19$ 
(q $\left.,{ }^{3} J=7 \mathrm{~Hz}, 4 \mathrm{H}, \mathrm{COOCH}_{2} \mathrm{CH}_{3}\right), 5.58\left(\mathrm{~d},{ }^{2} J=1.7 \mathrm{~Hz}, 1 \mathrm{H}, 3^{\prime \prime}-\mathrm{H}\right), 5.67$ (m , $1 \mathrm{H}, 3^{\prime \prime}-$ H), 7.25 - 7.40 (m, $5 \mathrm{H}$, phenyl-H).- ${ }^{13} \mathrm{C}-\mathrm{NMR}\left(\right.$ 62.5MHz, $\left.\mathrm{CDCl}_{3}, \mathrm{DEPT}\right): \delta=13.94(+$, $\mathrm{COOCH}_{2} \mathrm{CH}_{3}$ ) , 14.23 (-, C- 2'), 18.33 (-, C- 5'), 18.95 (-, C-8'), 27.81 (-, C-6 '*), 28.02 $\left(-, \mathrm{C}^{\prime *}{ }^{*}\right), 42.98\left(-, \mathrm{C}-1^{\prime \prime}\right), 56.47\left(\mathrm{C}_{\text {quart }}, \mathrm{C}-2\right), 61.65$ (-, $\left.\mathrm{COOCH}_{2} \mathrm{CH}_{3}\right), 78.79\left(\mathrm{C}_{\text {quart }}, \mathrm{C}-\right.$ 3'), 80.41 ( $C_{\text {quart }}, \mathrm{C}-4$ '), 80.79 ( $\mathrm{C}_{\text {quart }}$, C- 9'), 89.85 (C quart, C-10'), 121.89 (-, C-3"), 123.90 ( $\mathrm{C}_{\text {quart }}$, phenyl-C), 127.02 ( $\left.\mathrm{C}_{\text {quart }}, \mathrm{C}-2^{\prime \prime}\right), 127.49$ (+, o-phenyl-C), 128.15 (+, m-phenyl-C), 131.51 (+, p-phenyl-C), 170.12( $\left.\mathrm{C}_{\text {quart }}, \mathrm{COOCH}_{2} \mathrm{CH}_{3}\right)$.-MS (DCI, $\left.\mathrm{NH}_{3}, 70 \mathrm{eV}\right) \mathrm{m} / \mathrm{z}(\%)$ : 506 (100) $\left[\mathrm{M}+\mathrm{NH}_{4}^{+}\right] .-\mathrm{C}_{26} \mathrm{H}_{31} \mathrm{O}_{4} \mathrm{Br}(487.1)$

10-(1',3'-dioxolan-2'-yl)-1-phenyl-1,7-decacdiyne (56)

\section{Method A:}

By adapting GP1, $1.8 \mathrm{~g}$ (14.8 mmol) of 2-(3-butynyl)-1,3-dioxolane(64) was added at $-78{ }^{\circ} \mathrm{C}$ to a solution of $9.5 \mathrm{ml}(14.8 \mathrm{mmol})$ of n-butyl lithium

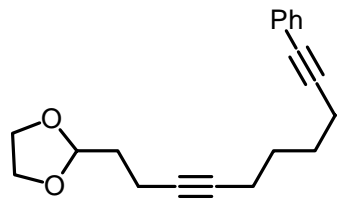
(1.56M in hexane) in $30 \mathrm{ml}$ of THF. After stirring for $15 \mathrm{~min}$, $2.6 \mathrm{ml}(14.4 \mathrm{mmol})$ of HMPA and $3.5 \mathrm{~g}$ (14.8 mmol) of 6bromo-1-phenyl hex-1-yne (51) were added sequentially to the reaction mixture. After stirring at $-78{ }^{\circ} \mathrm{C}$ for $1 \mathrm{~h}$, the reaction mixture was allowed to warm to room temperature and stirring was continued for additional $24 \mathrm{~h}$. Working up, as described in GP1, and purifying by column chromatography (80 g silica gel, 20:1 pentane/diethyl ether) afforded $2.5 \mathrm{~g}(60 \%)$ of a colorless liquid. $\left(\mathrm{R}_{\mathrm{f}}=0.28,10: 1\right.$ pentane/diethyl ether).

\section{Method B: Using Sonogashira Reaction}

$1.5 \mathrm{~g}$ (7.28 mmol) o 2-(3',9'-decadiynyl)-1,3-dioxoline(59) was added to a mixture of 30 $\mathrm{mg}(0.042 \mathrm{mmol})$ of dichlorobis(triphenylphosphine)palladium $\left[\mathrm{PdCl}_{2}\left(\mathrm{PPh}_{3}\right)_{2}\right], 20 \mathrm{mg}$ (0.1 mmol) of cuprous iodide (CuI), $40 \mathrm{mg}$ (0.15 mmol) of triphenylphosphine, $1.5 \mathrm{~g}$ $(7.30 \mathrm{mmol})$ of iodobenzene and $50 \mathrm{ml}$ of triethylamine $\left(\mathrm{Et}_{3} \mathrm{~N}\right)$. The reaction was stirred at $40{ }^{\circ} \mathrm{C}$ for $14 \mathrm{~h}$ during which a substantial amount of white solid was formed. The reaction mixture was then quenched with a saturated solution of ammonium chloride and 
extracted with $(5 \times 50 \mathrm{ml})$ diethyl ether. The combined ether layers were evaporated and the residue was purified by column chromatography (70 g silica gel , 20:1 pentane/diethyl ether) to afford $1.3 \mathrm{~g}(63 \%)$ of a colorless liquid.-IR (Film): $v=3056 \mathrm{~cm}^{-1}, 2942,2861$, 2837, 2230, 1951, 1877, 1598, 1490, 1441, 1330, 1146, 1128, 1072, 1046, 943, 896, 758, 693, 525.- ${ }^{1} \mathrm{H}-\mathrm{NMR}\left(250 \mathrm{MHz}, \mathrm{CDCl}_{3}\right.$ ): $\delta=1.61-1.73$ (m, $\left.4 \mathrm{H}, 4(5)-\mathrm{H}\right), 1.84$ (dt, ${ }^{3} J$ $\left.=4.8 \mathrm{~Hz}^{3} J=7.4 \mathrm{~Hz}, 2 \mathrm{H}, 10-\mathrm{H}\right), 2.17-2.33(\mathrm{~m}, 4 \mathrm{H}, 3(6)-\mathrm{H}), 2.42\left(\mathrm{t},{ }^{3} J=6.7 \mathrm{~Hz}, 2 \mathrm{H}\right.$, 9-H), 3.88 - 3.96 (m, 4 H, O-CH $\mathrm{CH}_{2}-\mathrm{O}$ ), 4.95 (t, $\left.{ }^{3} \mathrm{~J}=4.7 \mathrm{~Hz}, 1 \mathrm{H}, 2^{\prime}-\mathrm{H}\right), 7.24-7.41$ (m, $5 \mathrm{H}$, phenyl-H). $-{ }^{13} \mathrm{C}-\mathrm{NMR}\left(62.5 \mathrm{MHz}, \mathrm{CDCl}_{3}, \mathrm{DEPT}\right): \delta=13.72(-, \mathrm{C}-9), 18.30(-$, C-6), 18.95 (-, C-3), 27.79 (-, C-5*), 28.11 (-, C-4*), 33.32 (-, C-10), 64.89 (-, O$\mathrm{CH}_{2} \mathrm{CH}_{2}-\mathrm{O}$ ), 79.29 ( $\left.\mathrm{C}_{\text {quart }}, \mathrm{C}-8\right), 80.00$ (C $\left.\mathrm{C}_{\text {quart }}, \mathrm{C}-7\right)$, 80.76 ( $\left.\mathrm{C}_{\text {quart }}, \mathrm{C}-2\right), 89.90$ ( $\mathrm{C}_{\text {quart }}, \mathrm{C}-$ 1), 103.33 (+, C-2'), 123.92 ( $\mathrm{C}_{\text {quart, }}$ phenyl-C), 127.48 (+, o-phenyl-C), 128.14 (+, mphenyl-C), 131.50 (+, p-phenyl-C). - MS (DCI, $\mathrm{NH}_{3}, 70 \mathrm{eV}$ ) m/z (\%): 582 (2) $\left[2 \mathrm{M}+\mathrm{NH}_{4}^{+}\right], 300(100)\left[\mathrm{M}+\mathrm{NH}_{4}^{+}\right], 283$ (6) $\left[\mathrm{M}+\mathrm{H}^{+}\right] .-\mathrm{C}_{19} \mathrm{H}_{22} \mathrm{O}_{2}(282.2)$ calcd for: $\mathrm{C}$ 80.82, H 7.85; found: C 80.56, H 7.62

\section{2-bromo-14-phenyl-1-tetradecen-7,13-diyn-4-ol (70)}

According GP4,to a suspension of $0.73 \mathrm{~g}(6.1 \mathrm{mmol})$ of powder tin in diethyl ether(8.7

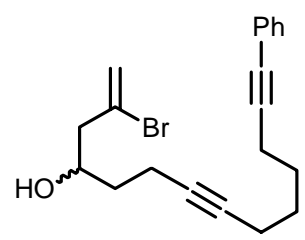
$\mathrm{ml}) /$ water(3.5ml) mixture (5:2 v/v) was added, successively, 1.2 g(6.1mmol) of 2,3-dibromopropene, 40 drops of $48 \% \mathrm{HBr}$ and 1.1 g(3.9 mmol) of 10-(1',3'-dioxolan-2'-yl)-1-phenyl-1,7-decacdiyne (56). The mixture was vigorously stirred for 5days at room temperature .The reaction mixture was then diluted with $150 \mathrm{ml}$ of water and $150 \mathrm{ml}$ of diethyl ether and extracted thoroughly with $(10 \times 100 \mathrm{ml})$ of diethyl ether. The combined ether layers were dried over $\mathrm{MgSO}_{4}$, and concentrated. The produced alcohol was immediately eluted from a column of silica gel (50 g), using (10:1) pentane/diethyl ether till the starting material was removed and then raising the polarity to $(20: 3)$ to remove the product, to afford $1 \mathrm{~g}(70 \%)$ of a colorless oil. $\left(\mathrm{R}_{\mathrm{f}}=0.18,20: 3\right.$ pentane/diethyl ether).-IR (Film): $v=3500 \mathrm{~cm}^{-1}$, 3079, 3056, 2948, 2901, 2838, 2228, 1949, 1876, 1631, 1490, 1439, 1331, 1121, 1068, 913, 891, 758, 693.- ${ }^{1}$ H-NMR ( 250 
$\left.\mathrm{MHz}, \mathrm{CDCl}_{3}\right): \delta=1.62-1.72(\mathrm{~m}, 6 \mathrm{H}, 5(10,11)-\mathrm{H}), 2.08(\mathrm{~s}, 1 \mathrm{H}, \mathrm{OH}), 2.22(\mathrm{~m}, 2 \mathrm{H}$, 12-H), 2.33 (m, 2 H, 9-H), 2.43 (m, 2 H, 6-H), 2.55 (d, ${ }^{2} J=6.25$ Hz, 2 H, 3-H), 4.10 (m, $1 \mathrm{H}, 4-\mathrm{H}), 5.53$ (d, $\left.{ }^{2} J=1.5 \mathrm{~Hz}, 1 \mathrm{H}, 1-\mathrm{H}\right), 5.69$ (d, $\left.{ }^{2} J=.85 \mathrm{~Hz}, 1 \mathrm{H}, 1-\mathrm{H}\right), 7.24-7.41$ (m, $5 \mathrm{H}$, phenyl-H). ${ }^{13} \mathrm{C}-\mathrm{NMR}\left(62.5 \mathrm{MHz}, \mathrm{CDCl}_{3}\right.$, DEPT): $\delta=15.37$ (-, C-6), 18.30 (-, C9), 18.97 (-, C-12), 27.81 (-, C-10*), 28.09 (-, C-11*), 35.09 (-, C-5), 49.11 (-, C-3), 68.38 (+, C-4), 79.55 (C $\left.\mathrm{C}_{\text {quart }}, \mathrm{C}-7\right), 80.84$ (C $\left.\mathrm{C}_{\text {quart }}, \mathrm{C}-8\right), 89.85$ (C $\left.\mathrm{C}_{\text {quart }}, \mathrm{C}-14\right), 119.64$ (-, C1), 123.90 ( $\mathrm{C}_{\text {quart }}$, phenyl-C), 127.50 (+, o-phenyl-C), 128.15 (+, m-phenyl-C), 130.42

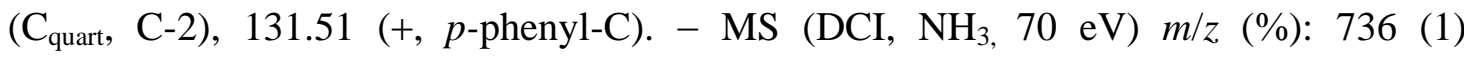
$\left[\begin{array}{lllllll}\left.2 \mathrm{M}+\mathrm{NH}_{4}{ }^{+}\right], & 376 / 378 & (100 / 98) & {\left[\mathrm{M}+\mathrm{NH}_{4}^{+}\right.}\end{array}\right], \quad 298 \quad(11) \quad\left[(\mathrm{M}-\mathrm{Br})+\mathrm{NH}_{4}{ }^{+}\right] \quad . \quad-$ $\mathrm{C}_{20} \mathrm{H}_{23} \mathrm{BrO}(358.2)$

1-(13'-bromo-11' -(tert-butyldimethylsilyloxy)-13' -tetradecen-1',7'-diynyl)benzene (49) According to GP5, $0.5 \mathrm{~g}(3.33 \mathrm{mmol})$ of tert-butyldimethylsilyl chloride was added at 55<smiles>C=C(Br)CC(CC#CCCCC#Cc1ccccc1)O[Mg]</smiles>
${ }^{\circ} \mathrm{C}$ to a solution of $1 \mathrm{~g}(2.77 \mathrm{mmol})$ of 2-bromo-14-phenyl-1tetradecen-7,13-diyn-4-ol (70) and $0.65 \mathrm{~g}(9.8 \mathrm{mmol})$ of imidazole in $10 \mathrm{ml} \mathrm{DMF}$. After stirring at $55^{\circ} \mathrm{C}$ for $12 \mathrm{~h}$, the reaction mixture was poured into $70 \mathrm{ml}$ of water and extracted with $(3 \times 40 \mathrm{ml})$ of diethyl ether. The combined ether layers were dried over $\mathrm{MgSO}_{4}$, and concentrated. The residue was purified by column chromatography (50 g silica gel and 80:1 pentane/diethyl ether) to afford $1.1 \mathrm{~g}(82 \%)$ of a colorless oil. $\left(\mathrm{R}_{\mathrm{f}}=\right.$ 0.63, 80:1 pentane/diethyl ether).-IR (Film) $: v=3081 \mathrm{~cm}^{-1}, 3053,2957,2928,2856$, 2232, 1631, 1490, 1434, 1362, 1255, 1075, 1005, 890, 836, 777, 755, 692.- ${ }^{1} \mathrm{H}-\mathrm{NMR}($ $\left.250 \mathrm{MHz}, \mathrm{CDCl}_{3}\right): \delta=0.095$ (s, 6 H, TBDMS-H), 0.88 ( s, 9 H, TBDMS- H), 1.67 1.72 (m, 6 H, 4' (5',10')-H), 2.22 (m, 4 H, 3 (6')-H), 2.40 - 2.47 (m, 2 H, 9'-H), 2.51 2.57 (dd, ${ }^{2} J=6.4 \mathrm{~Hz},{ }^{2} J=4 \mathrm{~Hz}, 2 \mathrm{H}, 12^{\prime}-\mathrm{H}$ ), 4.10 (m, 1H, $11^{\prime}-\mathrm{H}$ ), 5.43 (d, ${ }^{2} J=1.3 \mathrm{~Hz}, 1$ H, 14'-H), 5.61 (d, ${ }^{2} J=1.3$ Hz, 1 H, 14'-H), $7.24-7.41$ (m, 5 H, phenyl -H).- ${ }^{13} \mathrm{C}-\mathrm{NMR}$ ( $\left.62.5 \mathrm{MHz}, \mathrm{CDCl}_{3}, \mathrm{DEPT}\right): \delta=-4.60$ (+, TBDMS-C), -4.40 (+, TBDMS-C), $14.74(-$, C-9'), 18.022 (C quart TBDMS-C), 18.32 (-, C-6'), 18.99 (-, C-3'), 25.84 (+, TBDMS-C), $27.83\left(-, \mathrm{C}^{\prime *}{ }^{*}\right), 28.18$ (-, C-4'), 35.78 (-, C- 10'), 49.34 (-, C-12'), 68.83 (-, C-10'), 


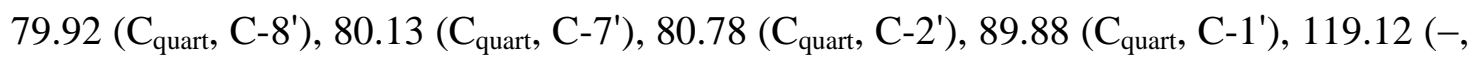
C-14'), 123.94 ( $\mathrm{C}_{\text {quart }}$ phenyl-C), 127.48 (+, o-phenyl-C), 128.14 (+, m-phenyl-C), 130.83 (C $\mathrm{C}_{\text {quart, }}, \mathrm{C}-13$ '), 131.51 (+, p-phenyl-C).- MS (DCI, $\left.\mathrm{NH}_{3}, 70 \mathrm{eV}\right) \mathrm{m} / \mathrm{z}(\%)$ : 490/492 (88/100) $\left[\mathrm{M}+\mathrm{NH}_{4}^{+}\right], 412(20)\left[(\mathrm{M}-\mathrm{Br})+\mathrm{NH}_{4}^{+}\right] .-\mathrm{C}_{26} \mathrm{H}_{37} \mathrm{BrOSi}(473.2)$

\section{1-(tert - butyldimethylsilyl) 1,8-octadiyne (86)}

The synthesis of this compound was reported using ethyl magnisium bromide as a base. ${ }^{[51]}$

$3.13 \mathrm{ml}(4.8 \mathrm{mmol})$ of n-butyl lithium was added at $-78{ }^{\circ} \mathrm{C}$ to a solution of $0.5 \mathrm{~g}(4.7$

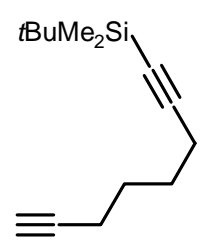
mmol) of 1,7-octadiyne in $15 \mathrm{ml}$ of THF and stirring was continued for $30 \mathrm{~min}$. To the resulting white suspension were added $0.82 \mathrm{ml}$ (4.7 mmol) of HMPA, $0.55 \mathrm{ml}(4.6 \mathrm{mmol})$ of DMPU and $0.7 \mathrm{~g}(4.7 \mathrm{~mol})$ of tert-butyldimethylsilyl chloride and the reaction mixture was allowed to warm to room temperature. After stirring for $20 \mathrm{~h}$ at room temperature, the reaction mixture was treated with $100 \mathrm{ml}$ diethyl ether and $30 \mathrm{ml}$ of a saturated solution of ammonium chloride. The aqueous layer was extracted with $(3 \times 50 \mathrm{ml})$ of diethyl ether and the combined organic phases were dried $\left(\mathrm{MgSO}_{4}\right)$ and concentrated. The resulting residue was purified by column chromatography (40 g silica gel, pentane) to afford $0.36 \mathrm{~g}$ (35\%) of 86 and $0.3 \mathrm{~g}(20 \%)$ of the disubstituted derivative.

${ }^{1} \mathrm{H}-\mathrm{NMR}\left(250 \mathrm{MHz}, \mathrm{CDCl}_{3}\right.$ ): $\delta=0.072$ (s, $6 \mathrm{H}, \mathrm{TBDMS}-\mathrm{H}$ ), 0.91 (s, 9 H, TBDMS- H), $1.60-1.66$ (m, 4 H, 4, 5-H), 1.94 (t, ${ }^{4} J=2.62$ Hz, 1 H, 8-H), $2.19-2.26$ (m, 4H, 3, 6H).- ${ }^{13} \mathrm{C}-\mathrm{NMR}\left(62.5 \mathrm{MHz}, \mathrm{CDCl}_{3}, \mathrm{DEPT}\right): \delta=-4.48$ (+, TBDMS-C), 16.48 (C quart, TBDMS-C), 17.87 (-, C-6), 19.29 (-, C-3), 26.04 (+, TBDMS-C), 27.38 (-, C-4*), 27.53 (-, C-5*), 68.40 (+, C-8), 82.10 ( $\left.\mathrm{C}_{\text {quart }}, \mathrm{C}-7\right), 84.10$ (C quart, $\left.\mathrm{C}-2\right), 107.35$ (C quart, C-1). 
1-(tert-butyldimethylsilyl)-1,7,13-tetradecatriyne (81)

By adapting GP1, $6 \mathrm{ml}$ (9.3 mmol) of n-butyl lithium (1.5M in hexane) was added, at -78<smiles>C#CCCCC#CCCCC#C[SiH2]C</smiles>
${ }^{\circ} \mathrm{C}$, dropwise to a solution of $0.96 \mathrm{~g}$ (9.1 mmol) of 1,7-octadiyne in $40 \mathrm{ml}$ of THF. After addition, the reaction was stirred for 30 min and to the resulting white suspension was added, sequentially, $1.6 \mathrm{ml}(9.1 \mathrm{mmol})$ of HMPA and $2.5 \mathrm{~g}(9.1 \mathrm{mmol})$ of 6-bromo-1-(tert-butyldimethylsilyl) hex-1-yne (82). Stirring was continued for $2 \mathrm{~h}$ at $-78{ }^{\circ} \mathrm{C}$ and $14 \mathrm{~h}$ at room temperature. The reaction mixture was diluted with $150 \mathrm{ml}$ of water, the two layers were separated, and the aqueous layer was extracted with $(5 \times 50 \mathrm{ml})$ of diethyl ether. The combined organic layers were dried $\left(\mathrm{MgSO}_{4}\right)$, concentrated, and the residue was purified by column chromatography $(60 \mathrm{~g}$ silica gel, pentane) to afford $1.2 \mathrm{~g}(45 \%)$ of a colorless liquid. $\left(\mathrm{R}_{\mathrm{f}}=0.4\right.$, pentane).-IR (Film) $: v=3313 \mathrm{~cm}^{-1}, 2955,2928,2857,2173,1680,1467,1252,1109,1009,840,776$, 679. ${ }^{1} \mathrm{H}-\mathrm{NMR}\left(250 \mathrm{MHz}, \mathrm{CDCl}_{3}\right): \delta=0.072$ (s, 6 H, TBDMS-H), 0.92 (s, 9 H, TBDMSH), 1.59 (m, 8 H, 4 (5,10,11)-H), 1.94 (t, ${ }^{4} J=2.64$ Hz, 1 H, 14-H), $2.16-2.27$ (m, 8 H, 3(6,9,12)-H).- ${ }^{13} \mathrm{C}-\mathrm{NMR}$ ( $\left.62.5 \mathrm{MHz}, \mathrm{CDCl}_{3}, \mathrm{DEPT}\right): \delta=-4.46$ (+,TBDMS-C), 16.49

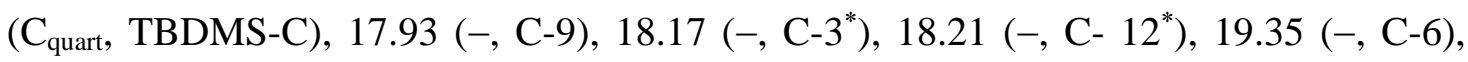
$26.04\left(+\right.$, TBDMS-C), $27.47\left(-, \mathrm{C}-10^{* *}\right), 27.71\left(-, \mathrm{C}-11^{* *}\right), 27.97\left(-, \mathrm{C}-5^{* * *}\right), 28.04(-$, C-4 $\left.{ }^{* * *}\right), 68.34(+, \mathrm{C}-14), 79.85\left(\mathrm{C}_{\text {quart }}, \mathrm{C}-13^{* * * *}\right), 80.03\left(\mathrm{C}_{\text {quart }}, \mathrm{C}-8^{* * * *}\right), 82.62\left(\mathrm{C}_{\text {quart }}, \mathrm{C}-\right.$ 7), 84.24 ( $\left.\mathrm{C}_{\text {quart }}, \mathrm{C}-2\right), 107.65$ (C $\left.\mathrm{C}_{\text {quart }}, \mathrm{C}-1\right)$ ). $\mathrm{MS}$ (DCI, NH3, $\left.70 \mathrm{eV}\right) \mathrm{m} / \mathrm{z}(\%): 318$ (100) $\left[\mathrm{M}+\mathrm{NH}_{4}^{+}\right], 300(18)\left[\mathrm{M}^{+}\right], 178$ (15), 161 (62), 154 (10). - $\mathrm{C}_{20} \mathrm{H}_{32} \mathrm{Si}(300.5)$ 
2-bromo-14-(tert-butyldimethylsilyl)-1-tetradecen-7,13,-diyne (79)

Method A: by brominating 1-(tert-butyldimethylsilyl)-1,7,13-tetradecatriyne with _BBromo-9-borabicyclo[3.3.1]nonane (B-Br-9-BBN)

According to GP7, $1 \mathrm{~g}$ (3.3mmol) of 1-(tert-butyldimethylsilyl)-1,7,13tetradecatriyne(81) was added, at $0{ }^{\circ} \mathrm{C}$, and under argon<smiles>C=C(Br)CCC#CCCCCC#CCCCCCCC</smiles>
atmosphere, to a solution of $(7.3 \mathrm{mmol})$ of $\mathrm{B}-\mathrm{Br}-9-\mathrm{BBN}(\mathbf{8 8})$ in 25 $\mathrm{ml}$ dichloromethane (prepared by adding $7.3 \mathrm{ml}$ of $1 \mathrm{M}$ of a commercially available solution of B-Br-9-BBN in dichloromethane to $17.7 \mathrm{ml}$ dichloromethane). After stirring for $3 \mathrm{~h}$ at $0{ }^{\circ} \mathrm{C}, 2 \mathrm{ml}$ of glacial acetic acid was added and stirring was continued for additional $1 \mathrm{~h}$ before adding $30 \mathrm{ml}$ of $3 \mathrm{M}$ aqueous sodium hydroxide followed by dropwise addition of $6 \mathrm{ml}$ of 30\% hydrogen peroxide. The reaction mixture was stirred for further $1 \mathrm{~h}$ and the resulting two layers were separated. The aqueous layer was extracted with $(3 \times 40 \mathrm{ml})$ dichlomethane and the combined organic layers were washed sequentially with $50 \mathrm{ml}$ of water, $50 \mathrm{ml}$ of saturated solution of sodium bicarbonate and $50 \mathrm{ml}$ of water. The combined organic layers were then dried $\left(\mathrm{MgSO}_{4}\right)$, concentrated, and the residue was eluted with pentane from a column of silica gel (50 g) to afford $0.2 \mathrm{~g}(16 \%)$ of a colorless oil.

Method B: by coupling with 1-(tert - butyldimethylsilyl) 1,8-octadiyne

$1.8 \mathrm{ml}$ (2.8 mmol) of n-butyl lithium (1.5M in hexane) was added at $-78{ }^{\circ} \mathrm{C}$, dropwise, to a solution of $0.6 \mathrm{~g}$ (2.71 mmol ) of 1-(tert - butyldimethylsilyl) 1,8-octadiyne in $15 \mathrm{ml}$ of THF. After addition, the reaction was stirred for $30 \mathrm{~min}$ and to the resulting white suspension was added, sequentially, $0.48 \mathrm{ml}(2.73 \mathrm{mmol})$ of HMPA and $0.78 \mathrm{~g}$ (2.71 mmol) of 2-bromo-6-iodohex-1-ene (85). Stirring was continued for $2 \mathrm{~h}$ at $-78{ }^{\circ} \mathrm{C}$ and 14 $\mathrm{h}$ at room temperature. The reaction mixture was diluted with $50 \mathrm{ml}$ of water, the two layers were separated, and the aqueous layer was extracted with $(5 \times 30 \mathrm{ml})$ of diethyl ether. The combined organic layers were dried $\left(\mathrm{MgSO}_{4}\right)$, concentrated, and the residue was purified by column chromatography (30 g silica gel, pentane) to afford $0.3 \mathrm{~g}$ (28\%) of a colorless oil. $\left(\mathrm{R}_{\mathrm{f}}=0.32\right.$, pentane).-IR (Film): $v=2956 \mathrm{~cm}^{-1}, 2928,2857,2173,1630$, 1602, 1467, 1362, 1251, 1175, 1083, 1007, 886, 842, 828, 572.- ${ }^{1} \mathrm{H}-\mathrm{NMR}$ (250 MHz, 
$\left.\mathrm{CDCl}_{3}\right): \delta=0.075$ (s, $\left.6 \mathrm{H}, \mathrm{TBDMS}-\mathrm{H}\right), 0.92$ (s, $\left.9 \mathrm{H}, \mathrm{TBDMS}-\mathrm{H}\right), 1.45-1.77$ (m, $8 \mathrm{H}, 4$, 5, 10, 11-H), $2.15-2.27$ (m, 6 H, 6, 9, 12-H), 2.43 (t, $\left.{ }^{3} J=6.88 \mathrm{~Hz}, 2 \mathrm{H}, 3-\mathrm{H}\right), 5.39$ (d, ${ }^{2} J$ $=1.52 \mathrm{~Hz}, 1 \mathrm{H}, 1-\mathrm{H}), 5.56\left(\mathrm{dd},{ }^{2} J=1.46 \mathrm{~Hz},{ }^{4} \mathrm{~J}=0.78 \mathrm{~Hz}, 1 \mathrm{H}, 1-\mathrm{H}\right) \cdot-{ }^{13} \mathrm{C}-\mathrm{NMR}(62.5$

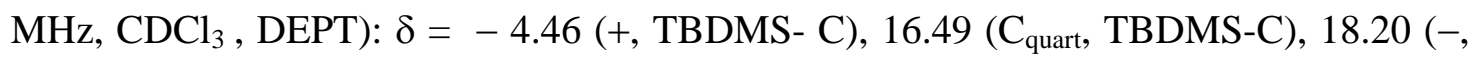
C-12), 18.43 (-, C-9*), 19.37 (-, C-6*), 26.05 (+, TBDMS-C), 26.93 (-, C-5), 27.69 (-, C-10**), $27.72\left(-\right.$, C-11**), 28.04 (-, C-4), 40.85 (-, C-3), $79.90\left(\mathrm{C}_{\text {quart }}, \mathrm{C}-7^{* * *}\right), 79.97$

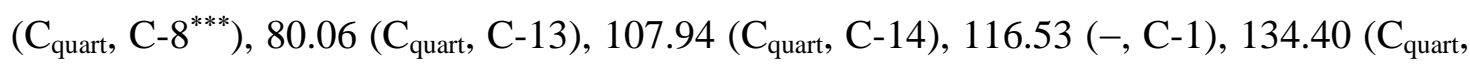
C-2).- MS (DCI, $\left.\mathrm{NH}_{3}, 70 \mathrm{eV}\right) \mathrm{m} / \mathrm{z}(\%)$ : 398/400 (94/100) [M+NH$\left.{ }_{4}^{+}\right], 381 / 383(16 / 18)$ $\left[\mathrm{M}^{+}\right] .-\mathrm{C}_{20} \mathrm{H}_{33} \mathrm{BrSi}(381.5)$

10-(1',3'-dioxolan-2'-yl)-1-(tert-butyldimethylsilyl)-1,7-decacdiyne (89)

\section{Method A}

According to GP1, $1.37 \mathrm{~g}$ (10.9 mmol) of 2-(3-butynyl)-1,3-dioxolane(59) was added at $-78{ }^{\circ} \mathrm{C}$ to a solution of $7.0 \mathrm{ml}(10.9 \mathrm{mmol})$ of n-butyl lithium

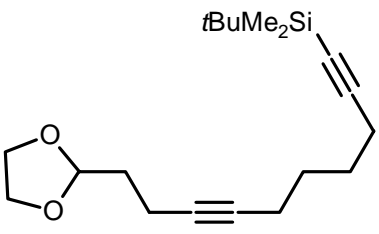
(1.56M in hexane) in $30 \mathrm{ml}$ of THF. After stirring for $15 \mathrm{~min}$, $1.91 \mathrm{ml}(10.9 \mathrm{mmol})$ of HMPA and $3 \mathrm{~g}(10.9 \mathrm{mmol})$ of 6bromo-1-(tert-butyldimethylsilyl) hex-1-yne (82) were added sequentially to the reaction mixture. After stirring at $-78{ }^{\circ} \mathrm{C}$ for

$1 \mathrm{~h}$, the reaction mixture was allowed to warm to room temperature and stirring was continued for additional $24 \mathrm{~h}$. Working up, as described in GP1, and purifying by column chromatography (100g silica gel, 20:1 pentane/diethyl ether) afforded $2.2 \mathrm{~g}$ (62\%) of a colorless liquid. $\left(\mathrm{R}_{\mathrm{f}}=0.37,10: 1\right.$ pentane/diethyl ether $)$.

\section{Method B}

$1.5 \mathrm{~g}$ (7.27 mmol) of 2-(3',9'-decadiynyl)-1,3-dioxoline (59) was added at $-78{ }^{\circ} \mathrm{C}$ to a solution of $3.6 \mathrm{ml}(7.2 \mathrm{mmol})$ of n-butyl lithium (2M in hexane) in $30 \mathrm{ml}$ of THF. After stirring for $15 \mathrm{~min}, 0.84 \mathrm{ml}(7 \mathrm{mmol})$ of DMPU and $1.2 \mathrm{~g}(8 \mathrm{mmol})$ of tertbutyldimethylsilyl chloride in $5 \mathrm{ml}$ THF were added sequentially to the reaction mixture. After stirring at $-78{ }^{\circ} \mathrm{C}$ for $1 \mathrm{~h}$, the reaction mixture was allowed to warm to room temperature and stirring was continued for additional $24 \mathrm{~h}$. The reaction was quenched 
with $5 \mathrm{ml}$ water, the two layers were separated, and the aqueous layer was extracted with $(3 \times 40 \mathrm{ml})$ of diethyl ether. The combined organic layers were dried $\left(\mathrm{MgSO}_{4}\right)$, concentrated, and purified by column chromatography (100 g silica gel, 20:1 pentane/diethyl ether) to afford $2 \mathrm{~g}$ (85\%) of colorless liquid.-IR (Film): $v=2957 \mathrm{~cm}^{-1}$, 2929, 2855, 2172, 1469, 1434, 1411, 1362, 1252, 1146, 1072, 897, 840, 775, 681.- ${ }^{1} \mathrm{H}-$ NMR ( $250 \mathrm{MHz}, \mathrm{CDCl}_{3}$ ): $\delta=0.072$ (s, $\left.6 \mathrm{H}, \mathrm{TBDMS}-\mathrm{H}\right)$, 0.91 ( s , 9 H,TBDMS-H), 1.59 (m, 4 H, 4(5)-H), 1.83 (dt, $\left.{ }^{3} J=7.3 \mathrm{~Hz},{ }^{2} J=4.7 \mathrm{~Hz}, 2 \mathrm{H}, 10-\mathrm{H}\right), 2.15-2.31(\mathrm{~m}, 6 \mathrm{H}$, 3(6,9)-H), 3.85 - 3.99 (m, $\left.4 \mathrm{H}, \mathrm{O}-\mathrm{CH}_{2} \mathrm{CH}_{2}-\mathrm{O}\right), 4.96$ (t, $\left.{ }^{3} \mathrm{~J}=4.7 \mathrm{~Hz}, 1 \mathrm{H}, 2^{1}-\mathrm{H}\right) .-{ }^{13} \mathrm{C}-\mathrm{NMR}$ (62.5 MHz, $\left.\mathrm{CDCl}_{3}, \mathrm{DEPT}\right): \delta=-4.62$ (+, TBDMS-C), 13.69 (-, C-9), 16.49 (C $\mathrm{C}_{\text {quart }}$, TBDMS-C), 18.20 (-, C-6), 19.35 (-, C-3), 26.05 (+, TBDMS-C), 27.69 (-, C-5*), 27.97 (-, C-4*), 33.22 (-, C-10), 64.90 (-, O- $\left.\mathrm{CH}_{2} \mathrm{CH}_{2}-\mathrm{O}\right), 79.21\left(\mathrm{C}_{\text {quart }}, \mathrm{C}-8\right)$, 79.97 (C $\mathrm{C}_{\text {quart }}$ C7), 82.61 ( $\left.\mathrm{C}_{\text {quart }}, \mathrm{C}-2\right), 103.33$ (+, C-2'), 107.63 (C quart, C-1). - MS (DCI, $\left.\mathrm{NH}_{3}, 70 \mathrm{eV}\right) \mathrm{m} / \mathrm{z}$ (\%): $658(0.1)\left[2 \mathrm{M}+\mathrm{NH}_{4}^{+}\right], 338(100)\left[\mathrm{M}+\mathrm{NH}_{4}{ }^{+}\right] .-\mathrm{C}_{19} \mathrm{H}_{32} \mathrm{O}_{2} \mathrm{Si}(320.2)$ calcd for: $\mathrm{C} 71.19$, H 10.06; found: C 71.36, H 10.00

2-bromo-14-(tert-butyldimethylsilyl)-1-tetradecen-7,13-diyn-4-ol (90)

According GP4, to a suspension of $1.3 \mathrm{~g}$ (11.24 mmol) of powder

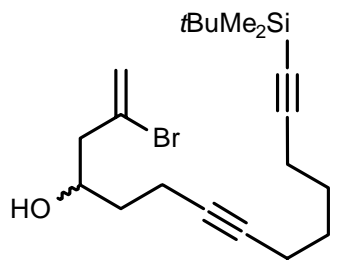
tin in diethyl ether $(8.7 \mathrm{ml}) /$ water $(3.5 \mathrm{ml})$ mixture $(5: 2 \mathrm{v} / \mathrm{v})$ was added, successively, $2.1 \mathrm{~g}(11.24 \mathrm{mmol})$ of 2,3- dibromopropene, 40 drops of $48 \% \mathrm{HBr}$ and $1.8 \mathrm{~g}(5.64 \mathrm{mmol})$ of 10-(1',3'-dioxolan2'-yl)-1- (tert-butyldimethylsilyl)-1,7-decacdiyne(89).The mixture was vigorously stirred for 5 days at room temperature. The reaction mixture was then diluted with $200 \mathrm{ml}$ of water and $200 \mathrm{ml}$ of diethyl ether and extracted thoroughly with $(12 \times 100 \mathrm{ml})$ of diethyl ether. The combined ether layers were dried over $\mathrm{MgSO}_{4}$, and concentrated. The produced alcohol was immediately purified by column chromatography (70 g silica gel, and 10:1 pentane/diethyl ether) to afford $1.6 \mathrm{~g}$ (71\%) of a colorless oil. $\left(\mathrm{R}_{\mathrm{f}}=0.22,10: 1\right.$ pentane/diethyl ether).-IR (Film): $v=3500 \mathrm{~cm}^{-1}, 2954$, 2928, 2856, 2173, 1631, 1468, 1363, 1251, 1121, 1065, 891, 840, 808, 775, 680, 597.- ${ }^{1} \mathrm{H}-$ 
NMR (250 MHz, $\mathrm{CDCl}_{3}$ ): $\delta=0.075$ (s, 6 H, TBDMS-H), 0.92 (s, 9 H, TBDMS-H), 1.59 - 1.69 (m, 6 H, 5 (10,11)-H), 2.05 (bs, 1 H, OH), 2.15 - 2.33 (m, 6 H, 6(9,12)-H), 2.55 (d, $\left.{ }^{3} J=6.35 \mathrm{~Hz}, 2 \mathrm{H}, 3-\mathrm{H}\right), 4.08$ (m, $\left.1 \mathrm{H}, 4-\mathrm{H}\right), 5.31$ (d, $\left.{ }^{2} J=2.1 \mathrm{~Hz}, 1 \mathrm{H}, 1-\mathrm{H}\right), 5.54$ (d, $\left.{ }^{2} J=1.8 \mathrm{~Hz}, 1 \mathrm{H}, 1-\mathrm{H}\right) .{ }^{13} \mathrm{C}-\mathrm{NMR}\left(62.5 \mathrm{MHz}, \mathrm{CDCl}_{3}\right.$, DEPT): $\delta=-4.45$ (+, TBDMSC), 15.37 (-, C-6), 16.49 (C quart, TBDMS-C), 18.19 (-, C-9), 19.36 (- , C-12), 26.06 (+, TBDMS-C), 27.72 (-, C-10*), 27.94 (-, C-11*), 35.10 (-, C-5), 49.13 (-, C-3), 68.37 (+, C-4), 79.48 ( $\left.\mathrm{C}_{\text {quart }}, \mathrm{C}-7\right), 80.81$ ( $\left.\mathrm{C}_{\text {quart, }} \mathrm{C}-8\right), 82.67$ ( $\left.\mathrm{C}_{\text {quart }}, \mathrm{C}-13\right), 107.58$ (C $\left.\mathrm{C}_{\text {quart }}, \mathrm{C}-14\right)$, 119.65 (-, C-1), 130.42 (C quart, C-2).- MS (DCI, $\mathrm{NH}_{3}, 70 \mathrm{eV}$ ) m/z (\%): 812 (8)

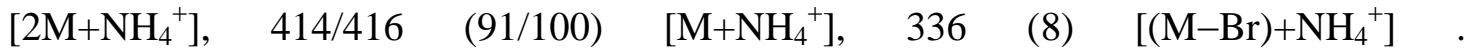
$-\mathrm{C}_{20} \mathrm{H}_{33} \mathrm{BrOSi}(397.2)$

2-bromo-4-(tert-butyldimethylsilyloxy)-14-(tert-butyldimythylsilyl)-1-tetradecen-7,13diyne (80)

According to GP5, $0.38 \mathrm{~g}(2.58 \mathrm{mmol})$ of tert-butyldimethylsilyl chloride was added at 55 ${ }^{\circ} \mathrm{C}$ to a solution of $0.85 \mathrm{~g}(2.14 \mathrm{mmol})$ of 2-bromo-14-(tert${ }_{\text {BuMe }_{2} \mathrm{SiO}^{2}}^{\mathrm{CBuMe}_{2} \mathrm{Si}}$ butyldimethylsilyl)-1-tetradecen-7,13-diyn-4-ol (90) and 0.5 $\mathrm{g}(7.5 \mathrm{mmol})$ of imidazole in $10 \mathrm{ml}$ DMF. After stirring at 55 ${ }^{\circ} \mathrm{C}$ for $12 \mathrm{~h}$, the reaction mixture was poured into $70 \mathrm{ml}$ of water and extracted with $(3 \times 40 \mathrm{ml})$ of diethyl ether. The combined ether layers were dried over $\mathrm{MgSO}_{4}$, and concentrated. The residue was purified by column chromatography (30 g silica gel and 80:1 pentane/diethyl ether) to afford $0.9 \mathrm{~g}(82 \%)$ of a colorless oil. $\left(\mathrm{R}_{\mathrm{f}}=0.79\right.$, 80:1 pentane/diethyl ether).-IR (Film): $v$ $=3314 \mathrm{~cm}^{-1}$, 2959, 2928, 2855, 2173, 1631, 1469, 1362, 1254, 1101, 1077, 1006, 840, 774, 681.- ${ }^{1} \mathrm{H}-\mathrm{NMR}$ ( $250 \mathrm{MHz}, \mathrm{CDCl}_{3}$ ): $\delta=0.072$ (s, $\left.3 \mathrm{H}, \mathrm{C}-\mathrm{TBDMS}-\mathrm{H}\right), 0.076$ (s, $3 \mathrm{H}$, O- TBDMS-H), 0.88 (s, 9 H, C-TBDMS-H), 0.92 (s, 9 H, O -TBDMS-H), 1.52 - 1.72 (m, 6 H, 5 (10,11)-H), $2.17-2.27$ (m, $6 \mathrm{H}, 6$ (9,12)-H), 2.48 (dd, ${ }^{2} J=6.4 \mathrm{~Hz},{ }^{3} J=14.1$ Hz, $1 \mathrm{H}, 3-\mathrm{H}$ ), 2.58 (dd, ${ }^{2} J=6.1 \mathrm{~Hz},{ }^{3} J=14.1 \mathrm{~Hz}, 1 \mathrm{H}, 3-\mathrm{H}$ ), 4.07 (m, $1 \mathrm{H}, 4$-H), 5.43 (s, $1 \mathrm{H}, 1-\mathrm{H}), 5.61$ (s, $1 \mathrm{H}, 1-\mathrm{H}) .-{ }^{13} \mathrm{C}-\mathrm{NMR}\left(62.5 \mathrm{MHz}, \mathrm{CDCl}_{3}, \mathrm{DEPT}\right): \delta=-4.61(+, \mathrm{C}-$ TBDMS-C), - 4.40 (+, O-TBDMS-C), 14.71 (-, C-6), 16.49 (C quart, C-TBDMS-C), 


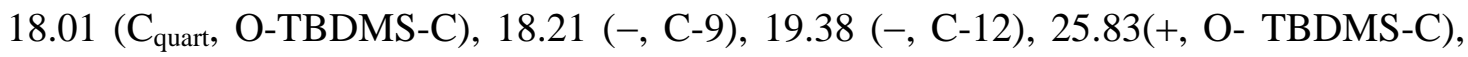
26.06 (+, C-TBDMS-C), 27.75 (-, C-10*), 28.08 (- , C-11*), 35.77 (-, C- 5), 49.32 (- , C-3), 68.83 (+ , C-4), 77.49 ( $\left.\mathrm{C}_{\text {quart }}, \mathrm{C}-7\right), 79.85$ (C $\left.\mathrm{C}_{\text {quart }}, \mathrm{C}-8\right), 80.09\left(\mathrm{C}_{\text {quart }}, \mathrm{C}-13\right), 107.62$

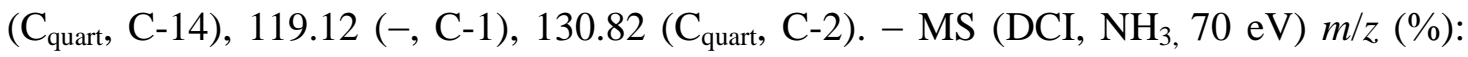
$528 / 530 \quad(88 / 100) \quad\left[\mathrm{M}+\mathrm{NH}_{4}{ }^{+}\right], \quad 513 \quad\left[\mathrm{M}+\mathrm{H}^{+}\right], \quad 450 \quad$ (4) $\quad\left[(\mathrm{M}-\mathrm{Br})+\mathrm{NH}_{4}{ }^{+}\right]$. $-\mathrm{C}_{26} \mathrm{H}_{47} \mathrm{BrOSi}_{2}(511.3)$

2-(3',9'-decadiynyl)-1,3-dioxoline (59)

Method A: by using tetrabutylammonium fluoride

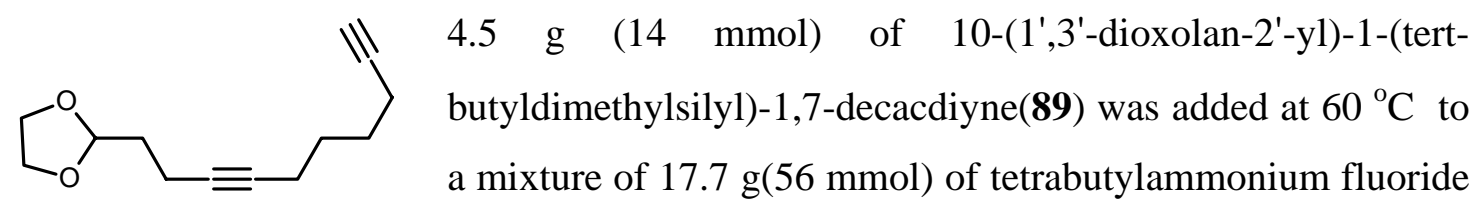
in $270 \mathrm{ml}$ THF and $2.2 \mathrm{ml}$ of water. After stirring for $12 \mathrm{~h}$ at $60{ }^{\circ} \mathrm{C}, 200 \mathrm{ml}$ of water was added, the two layers were separated, and the aqueous layer was extracted with $(3 \times 150$ $\mathrm{ml}$ ) of diethyl ether. The combined organic layers were dried $\left(\mathrm{MgSO}_{4}\right)$, concentrated, and the residue was purified by column chromatography (70 g silica gel , 20:1 pentane/diethyl ether $)$ to afford $2.3 \mathrm{~g}(80 \%)$ of a colorless liquid. $\left(\mathrm{R}_{\mathrm{f}}=0.30,10: 1\right.$ pentane/diethyl ether).

Method B: coupling of 1,7-octadiyne with 2-(1,3-dioxolan-2-yl)ethyl iodide

$12.5 \mathrm{ml}$ (18.7 mmol) of butyl lithium (1.5M in hexane) was added at $-78{ }^{\circ} \mathrm{C}$, dropwise, to a solution of $2 \mathrm{~g}$ (18.8 mmol) of 1,7-octadiyne in $40 \mathrm{ml}$ of THF. After addition, the reaction was stirred for $30 \mathrm{~min}$ and to the resulting white suspension was added, sequentially, $3.3 \mathrm{ml}$ (18.8 mmol) of HMPA and $4.5 \mathrm{~g}$ (19.7 mmol ) of 2-(1,3-dioxolan-2yl)ethyl iodide(61). Stirring was continued for $2 \mathrm{~h}$ at $-78{ }^{\circ} \mathrm{C}$ and $14 \mathrm{~h}$ at room temperature. The reaction mixture was diluted with $150 \mathrm{ml}$ of water, the two layers were separated, and the aqueous layer was extracted with $(5 \times 50 \mathrm{ml})$ of diethyl ether. The combined organic layers were dried $\left(\mathrm{MgSO}_{4}\right)$, concentrated, and the residue was purified by column chromatography ( 70 g silica gel , 40:1 pentane/diethyl ether) to afford 1.8g(46\%) of a colorless liquid.$\left(\mathrm{R}_{\mathrm{f}}=0.16,40: 1\right.$ pentane/diethyl ether).-IR (Film): $v=$ $3287 \mathrm{~cm}^{-1} 1,2944,2863,2712,2657,2116,1434,1412,1330,1147,1127,1072,1045$, 
943, 898, 626.- ${ }^{1} \mathrm{H}-\mathrm{NMR}\left(250 \mathrm{MHz}, \mathrm{CDCl}_{3}\right): \delta=1.55$ - 1.68 (m, 4 H, 6'(7')-H ), 1.82 (dt, $\left.{ }^{3} J=4.8 \mathrm{~Hz},{ }^{3} J=7.4 \mathrm{~Hz}, 2 \mathrm{H}, 1^{\prime}-\mathrm{H}\right), 1.93\left(\mathrm{t},{ }^{4} \mathrm{~J}=2.6 \mathrm{~Hz}, 1 \mathrm{H}, 10^{\prime}-\mathrm{H}\right), 3.81-3.91$ (m, 4 $\mathrm{H}, \mathrm{O}-\mathrm{CH}_{2} \mathrm{CH}_{2}-\mathrm{O}$ ), 4.95 (t, $\left.{ }^{3} \mathrm{~J}=4.8 \mathrm{~Hz}, 1 \mathrm{H}, 2-\mathrm{H}\right) .{ }^{13} \mathrm{C}-\mathrm{NMR}$ ( $62.5 \mathrm{MHz}, \mathrm{CDCl}_{3}$, DEPT): $\delta=13.68\left(-, \mathrm{C}^{\prime} 2^{\prime}\right), 17.92\left(-, \mathrm{C}^{\prime \prime *}\right), 18.20\left(-, \mathrm{C}-8^{\prime *}\right), 27.46\left(-, \mathrm{C}-6^{\prime * *}\right), 27.88(-$, C- $7^{\text {'**) }}$ ) 33.30 (-, C-1'), 64.88 (-, O- $\left.\mathrm{CH}_{2} \mathrm{CH}_{2}-\mathrm{O}\right), 68.34$ (+, C-10'), 79.30 ( $\mathrm{C}_{\text {quart, }}$ C-3'), 79.84 ( $\left.\mathrm{C}_{\text {quart }}, \mathrm{C}-5^{\prime}\right), 84.21$ (C $\mathrm{C}_{\text {quart }}, \mathrm{C}^{-9}$ '), 103.31 (+, C-2). - MS (DCI, $\left.\mathrm{NH}_{3}, 70 \mathrm{eV}\right) \mathrm{m} / \mathrm{z}$ (\%): 430 (11) $\left[2 \mathrm{M}+\mathrm{NH}_{4}^{+}\right], 224$ (100) $\left[\mathrm{M}+\mathrm{NH}_{4}^{+}\right], 207$ (6) $\left[\mathrm{M}+\mathrm{H}^{+}\right] .-\mathrm{C}_{13} \mathrm{H}_{18} \mathrm{O}_{2}(206.1)$ calcd for: C 75.69, H 8.75; found: C 75.61, H 8.60

\section{2-bromo-1-tetradecen-7,13-diyn-4-ol (116)}

According GP4, to a suspension of $2 \mathrm{~g}$ (17.2 mmol) of powder tin in diethyl ether(16.6<smiles>C#CCCCC#CCCC(O)CC(=C)Br</smiles>
$\mathrm{ml}) /$ water(6.5ml) mixture (5:2 v/v) was added, successively, 3.3 g (16.6mmol) of 2,3- dibromopropene, 40 drops of $48 \% \mathrm{HBr}$ and $2.5 \mathrm{~g}$ (12.2 mmol) of 2-(3',9'-decadiynyl)-1,3-dioxoline(59). The mixture was vigorously stirred for 5 days at room temperature.

The reaction mixture was then diluted with $200 \mathrm{ml}$ of water and $200 \mathrm{ml}$ of diethyl ether and extracted thoroughly with $(12 \times 100 \mathrm{ml})$ of diethyl ether. The combined ether layers were dried over $\mathrm{MgSO}_{4}$, and concentrated. The produced alcohol was immediately eluted from a column of silica gel (70 g) using a polarity gradient from (10:1) pentane/diethyl ether to (20:3) pentane/diethyl ether after removing the starting material to afford 1.8 $\mathrm{g}(52 \%)$ of a colorless oil. $\left(\mathrm{R}_{\mathrm{f}}=0.20,10: 3\right.$ pentane/diethyl ether).-IR (Film): $v=3500$ $\mathrm{cm}^{-1}$, 3305, 2948, 2862, 2173, 2116, 1719, 1631, 1432, 1330, 1120, 1070, 893, 842, 634.- ${ }^{1} \mathrm{H}-\mathrm{NMR}\left(250 \mathrm{MHz}, \mathrm{CDCl}_{3}\right): \delta=1.59-1.69$ (m, $\left.4 \mathrm{H}, 10(11)-\mathrm{H}\right), 1.94\left(\mathrm{t},{ }^{4} \mathrm{~J}=2.5\right.$ Hz, 1 H, 14-H), 2.07 ( bs, 1 H, OH), $2.15-2.24$ (m, 4 H, 9 (12)-H), 2.27 - 2.37 (m, 2H, 6-H), 2.55 (d, $\left.{ }^{3} J=6.30 \mathrm{~Hz}, 2 \mathrm{H}, 3-\mathrm{H}\right), 4.09$ (m, $\left.1 \mathrm{H}, 4-\mathrm{H}\right), 5.53$ (d, ${ }^{2} J=1.5 \mathrm{~Hz}, 1 \mathrm{H}, 1-$ H), $5.69\left(\mathrm{~d},{ }^{2} J=0.87 \mathrm{~Hz}, 1 \mathrm{H}, 1-\mathrm{H}\right) \cdot-{ }^{13} \mathrm{C}-\mathrm{NMR}\left(62.5 \mathrm{MHz}, \mathrm{CDCl}_{3}, \mathrm{DEPT}\right): \delta=15.33$ (-, C-6), 17.94 (-, C-9), 18.21 (-, C-12), 27.49 (-, C-10*), 27.87 (-, C -11*), 35.11 (-,

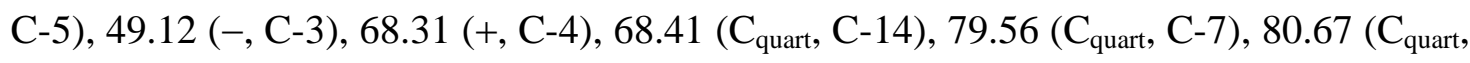




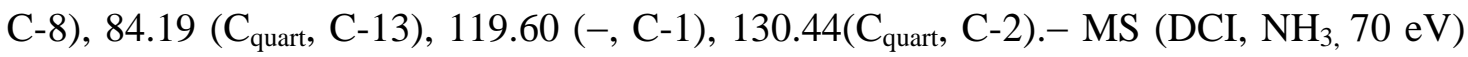
$\mathrm{m} / \mathrm{z}(\%): 584$ (6) $\left[2 \mathrm{M}+\mathrm{NH}_{4}{ }^{+}\right], 301(100)\left[\mathrm{M}+\mathrm{NH}_{4}{ }^{+}\right]$.

$-\mathrm{C}_{14} \mathrm{H}_{19} \mathrm{BrO}(283.0)$

\section{2-bromo-4-(tert-butyldimethylsilyloxy1)-1-tetradecen-7,13-diyne (117)}

According to GP5, $1.2 \mathrm{~g}$ (8 mmol) of tert-butyldimethylsilyl chloride was added at $55^{\circ} \mathrm{C}$ to a solution of $1.6 \mathrm{~g}$ (5.67 mmol) of 2-bromo-1-tetradecen-7,13-diyn-4-ol (116) and 1.3<smiles>C#CCCCC#CCCC(CC(=C)Br)O[Na]</smiles>
g(19.84 mmol) of imidazole in $20 \mathrm{ml}$ DMF. After stirring at $55{ }^{\circ} \mathrm{C}$ for $12 \mathrm{~h}$, the reaction mixture was poured into $100 \mathrm{ml}$ of water and extracted with $(3 \times 50 \mathrm{ml})$ of diethyl ether. The combined ether layers were dried over $\mathrm{MgSO}_{4}$, and concentrated. The residue was purified by column chromatography (50 g silica gel and 80:1 pentane/diethyl ether) to afford $2 \mathrm{~g}(89 \%)$ of a colorless oil. $\left(\mathrm{R}_{\mathrm{f}}=0.71,80: 1\right.$ pentane/diethyl ether).-IR (Film): $v=3311 \mathrm{~cm}^{-1}, 2959,2928,2857,1631,1469,1432$, 1255, 1101, 1077, 1005, 836, 776, 628.- ${ }^{1} \mathrm{H}-\mathrm{NMR}$ (250 MHz, $\left.\mathrm{CDCl}_{3}\right): \delta=0.087$ (s, $6 \mathrm{H}$, TBDMS-H), 0.91 (s, 9 H, TBDMS -H), $1.52-1.74$ (m, $6 \mathrm{H}, 5,10,11-\mathrm{H}), 1.93\left(\mathrm{t},{ }^{4} \mathrm{~J}=\right.$ $2.6 \mathrm{~Hz}, 1 \mathrm{H}, 14-\mathrm{H}), 2.15$ - 2.23 (m, 6 H, 6, 9, 12-H), 2.44 - 2.62 (m, 2 H, 3-H), 4.08 (m, $1 \mathrm{H}, 4-\mathrm{H}), 5.43$ (d, $\left.{ }^{2} \mathrm{~J}=1.47 \mathrm{hz}, 1 \mathrm{H}, 1-\mathrm{H}\right), 5.60$ (bs, $\left.1 \mathrm{H}, 1-\mathrm{H}\right) \cdot-{ }^{13} \mathrm{C}-\mathrm{NMR}(62.5 \mathrm{MHz}$, $\left.\mathrm{CDCl}_{3}, \mathrm{DEPT}\right): \delta=-4.62$ (+, TBDMS-C), - 4.40 (+, TBDMS-C), 14.71 (-, C-6), 17.96 (-, C-9), 18.01 ( $\mathrm{C}_{\text {quart }}$, TBDMS-C), 18.22 (-, C-12), 25.74 (+, TBDMS-C), 27.51 (-, C$\left.10^{*}\right), 27.95$ (-, C-11*), 35.76 (-, C-5), 49.32 (-, C-3), 68.35 (C 79.93 ( $\left.\mathrm{C}_{\text {quart }}, \mathrm{C}-7\right), 80.00$ (C $\left.\mathrm{C}_{\text {quart }}, \mathrm{C}-8\right), 84.21\left(\mathrm{C}_{\text {quart }}, \mathrm{C}-13\right), 119.11$ (-, C-1),130.82 (C quart,

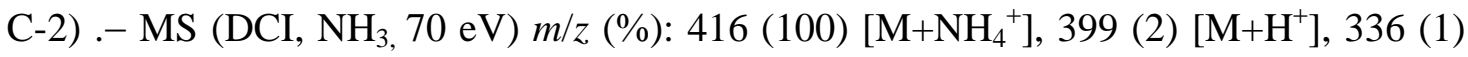
$\left[(\mathrm{M}-\mathrm{Br})+\mathrm{NH}_{4}{ }^{+}\right] .-\mathrm{C}_{20} \mathrm{H}_{33} \mathrm{BrOSi}(397.2)$ calcd for: $\mathrm{C}$ 60.44, $\mathrm{H}$ 8.37; found: $\mathrm{C}$ 60.27, $\mathrm{H}$ 8.11 
Dimethyl 14-methylene-12-(tert-butyldimethylsilyloxy)-2,8-pentadecadiynedioate (118) To a solution of $0.9 \mathrm{~g}$ (2.27 mmol) of 2-bromo-4-(tert-butyldimethylsilyloxy1)-1(1.56M in hexane) and the stirring was continued for
further $30 \mathrm{~min}$. The solution was then transferred into a actone-dry-ice cooled dropping funnel and it was added at $-78{ }^{\circ} \mathrm{C}$, over two hours, into a solution of $0.46 \mathrm{~g}(4.7 \mathrm{mmol})$ of chloromethylformate in $20 \mathrm{ml}$ THF. The stirring was continued for $1 \mathrm{~h}$ at $-78{ }^{\circ} \mathrm{C}$ and $2 \mathrm{~h}$ at room temperature. The reaction was then treated with $30 \mathrm{ml}$ of a saturated solution of $\mathrm{NaHCO}_{3}$ and extracted with $(3 \times 40 \mathrm{ml})$ of diethyl ether. The combined ether fractions were dried $\left(\mathrm{MgSO}_{4}\right)$ and concentrated. The resulting residue was purified by column chromatography (30 g silica gel, 10:1pentane/diethyl ether) to afford $0.48 \mathrm{~g}$ (48\%) of a colorless oil. $\left(\mathrm{R}_{\mathrm{f}}=0.32,10: 1\right.$ pentane/diethyl ether). ${ }^{1} \mathrm{H}-\mathrm{NMR}\left(250 \mathrm{MHz}, \mathrm{CDCl}_{3}\right): \delta=$ 0.092 (s, 6 H, TBDMS-H), 0.86 (s, 9 H, TBDMS-H), 1.54 - 184 (m, 6 H, 5(6,11)-H), 2.14 - 2.29 (m, 4 H, 7(10)-H), 2.35 (t, ${ }^{3} J=6.9 \mathrm{~Hz}, 2 \mathrm{H}, 4-\mathrm{H}$ ), 2.50 (dd, ${ }^{2} J=7.5 \mathrm{~Hz},{ }^{3} \mathrm{~J}=$ 14.2 Hz, 2 H, 14-H), 3.74 (s, 3 H, $\mathrm{COOCH}_{3}$ ), 3.75 (s, 3 H, COOCH ${ }_{3}$ ), 4.94 (m, 1 H, $12-$ H), $5.43\left(\mathrm{~d},{ }^{2} \mathrm{~J}=2.4 \mathrm{~Hz}, 1 \mathrm{H},=\mathrm{CH}_{2}\right), 5.73\left(\mathrm{~d},{ }^{2} \mathrm{~J}=2.5 \mathrm{~Hz}, 1 \mathrm{H},=\mathrm{CH}_{2}\right) \cdot{ }^{13} \mathrm{C}-\mathrm{NMR}(62.5$ $\left.\mathrm{MHz}, \mathrm{CDCl}_{3}, \mathrm{DEPT}\right): \delta=-6.13$ (+, TBDMS-C), -5.95 (+, TBDMS-C), 15.04 (-, C-

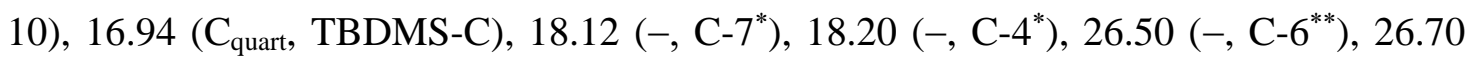
(+, TBDMS-C), 27.84 (-, C- 5**), 33.23 (-, C-11), 41.30 (-, C-13), 52.53 (+, $\mathrm{COOCH}_{3}$ ), 54.54 (+, $\left.\mathrm{COOCH}_{3}\right), 72.98\left(\mathrm{C}_{\text {quart }}, \mathrm{C}-2\right), 77.50$ (+, C-12), 79.35 (C $\left.\mathrm{C}_{\text {quart }}, \mathrm{C}-9\right), 79.89$ ( $\mathrm{C}_{\text {quart }}$, C-8), 89.38 ( $\left.\mathrm{C}_{\text {quart }}, \mathrm{C}-3\right), 129.44\left(-,=\mathrm{CH}_{2}\right), 144.75$ ( $\left.\mathrm{C}_{\text {quart }}, \mathrm{C}-14\right), 155.40$ (C quart, $\left.\mathrm{COOCH}_{3}\right), 162.0\left(\mathrm{C}_{\text {quart }}, \mathrm{COOCH}_{3}\right)$. - MS (DCI, $\left.\mathrm{NH}_{3}, 70 \mathrm{eV}\right) \mathrm{m} / \mathrm{z}(\%): 886$ (4) $\left[2 \mathrm{M}+\mathrm{NH}_{4}^{+}\right], 452(100)\left[\mathrm{M}+\mathrm{H}^{+}\right] .-\mathrm{C}_{24} \mathrm{H}_{38} \mathrm{O}_{5} \mathrm{Si}(434.6)$ 
Methyl-14-bromo-12-(tert-butyldimethylsilyloxy)-14-pentadecene-2,8-diynoate (111)

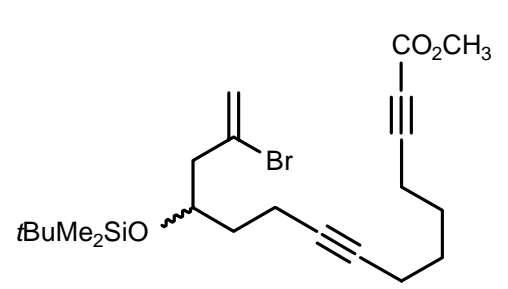

By adapting GP6, a solution of LDA (4.2 mmol) in 10 $\mathrm{ml}$ THF (prepared by dropwise addition, at $-78{ }^{\circ} \mathrm{C}$, of $0.42 \mathrm{~g}$ ( $4.2 \mathrm{mmol})$ of diisopropylamine to a solution of $2.8 \mathrm{ml}$ (4.2 mmol) of butyl lithium (1.56M in hexane) in $10 \mathrm{ml}$ THF and stirring for $30 \mathrm{~min}$ ) was added dropwise, at $-78{ }^{\circ} \mathrm{C}$, to a solution of $1.5 \mathrm{~g}$ (3.8 mmol) of 2-bromo-4-(tertbutyldimethylsilyloxy1)-1-tetradecen-7,13-diyne (117) in $10 \mathrm{ml}$ THF. After stirring for $30 \mathrm{~min}, 0.7 \mathrm{ml}$ (3.9 mmol) of HMPA and $2.9 \mathrm{ml}$ (37mmol) of chloromethylformate were added and stirring was continued for $1 \mathrm{~h}$ at $-78{ }^{\circ} \mathrm{C}$ and $2 \mathrm{~h}$ at room temperature. After working up, as described in GP6, the resulting residue was purified by column chromatography (60 g silica gel and 40:1 pentane/diethyl ether) to afford $0.7 \mathrm{~g}$ (40\%) of colorless oil. $\left(\mathrm{R}_{\mathrm{f}}=0.33,20: 1\right.$ pentane/diethyl ether).-IR (Film): $v=2950 \mathrm{~cm}^{-1}, 2928$, 2843, 2173, 1750, 1250, 1073, 941, 823, 764.- ${ }^{1} \mathrm{H}-\mathrm{NMR}\left(250 \mathrm{MHz}, \mathrm{CDCl}_{3}\right): \delta=0.09$ (s, 6 H, TBDMS-H), 0.87 (s, 9 H, TBDMS-H), 1.52 - 1.73 (m, 6 H, 5(6,11)-H), 2.15 - 2.23 (m, 4 H, 7(10)-H), 2.35 (t, ${ }^{3} J=6.8 H z, 2$ H, 4-H), 2.47 - 2.57 (m, 2 H, 13-H), 3.75 (s, 3 H, $\left.\mathrm{COOCH}_{3}\right), 4.06$ (m, $\left.1 \mathrm{H}, 12-\mathrm{H}\right), 5.43\left(\mathrm{~d},{ }^{2} \mathrm{~J}=1.5 \mathrm{~Hz}, 1 \mathrm{H}, 15-\mathrm{H}\right), 5.60\left(\mathrm{~d},{ }^{2} J=1.13 \mathrm{~Hz}, 1\right.$ H, 15-H). $-{ }^{13} \mathrm{C}-\mathrm{NMR}\left(62.5 \mathrm{MHz}, \mathrm{CDCl}_{3}\right.$, DEPT): $\delta=-4.62$ (+, TBDMS-C), - $4.40(+$, TBDMS-C), 14.69(-, C -10), 18.01 (C quart, TBDMS-C), 18.15 (-, C-7), 18.23 (-, C-4), 25.82 (+, TBDMS-C), 26.54 (-, C-6), 27.92 (-, C-5), 35.73 (-, C-11), 49.32 (-, C-13), 52.55 (+, $\mathrm{COOCH}_{3}$ ), 68.82 (+, C-12), 77.19 ( $\left.\mathrm{C}_{\text {quart }}, \mathrm{C}-9\right), 79.61$ (C $\left.\mathrm{C}_{\text {quart }}, \mathrm{C}-8\right), 80.24$ (C quart,

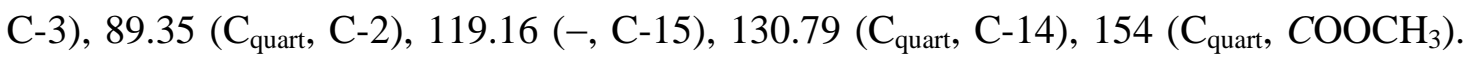

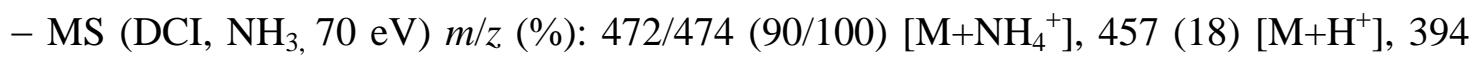
(18) $\left[(\mathrm{M}-\mathrm{Br})+\mathrm{NH}_{4}^{+}\right] .-\mathrm{C}_{22} \mathrm{H}_{35} \mathrm{BrO}_{3} \mathrm{Si}(455.5)$ 


\section{3,9-decadiyn-1-ol (112)}

$17.6 \mathrm{ml}$ (27.4 mmol) of n-butyl lithium (1.56M in hexane) was added at $-78{ }^{\circ} \mathrm{C}$,

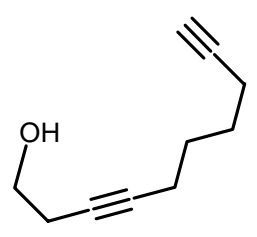
dropwise, to a solution of $3 \mathrm{~g}$ (28.3 mmol) of 1,7-octadiyne in 175 $\mathrm{ml}$ of THF. After stirring for $30 \mathrm{~min}$, $3.5 \mathrm{ml}$ (27.8 mmol) of boron trifluoride ether complex $\left(\mathrm{BF}_{3} \cdot \mathrm{Et}_{2} \mathrm{O}\right)$ was added to the resulting white suspension. The reaction mixture was stirred for further 15 min followed by addition of $14.11 \mathrm{ml}(283 \mathrm{mmol})$ of ethylene oxide. After stirring for 2 $\mathrm{h}$, the reaction mixture was quenched at $-78{ }^{\circ} \mathrm{C}$ with $120 \mathrm{ml}$ of saturated solution of ammonium chloride and extracted with $(4 \times 100 \mathrm{ml})$ of diethyl ether. The combined ether fractions were dried $\left(\mathrm{MgSO}_{4}\right)$, concentrated, and the residue was purified by column chromatography (60 g of silica gel and 2:1 pentane/diethyl ether) to afford $2.5 \mathrm{~g}$ (60\%) of a colorless liquid. $\left(\mathrm{R}_{\mathrm{f}}=0.6,1: 1\right.$ pentane/diethyl ether).IR (Film): $v=3303 \mathrm{~cm}^{-} 1,2950$, 2863, 2116, 1431, 1330, 1272, 1186, 1038, 849, 621.- ${ }^{1} \mathrm{H}-\mathrm{NMR}\left(250 \mathrm{MHz}, \mathrm{CDCl}_{3}\right): \delta=$ 1.60 (m, 4 H, 6, 7-H), 1.80 (bs, $1 \mathrm{H}, \mathrm{OH}), 1.94$ (t, $\left.{ }^{4} \mathrm{~J}=2.65 \mathrm{~Hz}, 1 \mathrm{H}, 10-\mathrm{H}\right), 2.15-2.23$ (m, 4 H, 5, 8-H), 2.41 (m, 2 H, 2-H), 3.66 (t, $\left.{ }^{3} J=6.0 \mathrm{~Hz}, 2 \mathrm{H}, 1-\mathrm{H}\right) .-{ }^{13} \mathrm{C}-\mathrm{NMR}$ ( 62.5 $\left.\mathrm{MHz}, \mathrm{CDCl}_{3}, \mathrm{DEPT}\right): \delta=17.88$ (-, C-5), 18.23 (-, C-8), 23.11 (-, C-2), 27.30 (-, C-

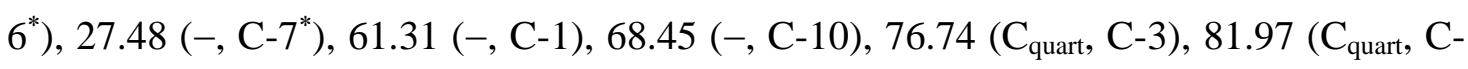
4), 84.14 (C $\mathrm{C}_{\text {quart, }}$ C-9). - MS (DCI, $\left.\mathrm{NH}_{3}, 70 \mathrm{eV}\right) \mathrm{m} / \mathrm{z}(\%): 185$ (93) $\left[\mathrm{M}+\mathrm{N}_{2} \mathrm{H}_{7}^{+}\right], 168$ (100) $\left[\mathrm{M}+\mathrm{NH}_{4}^{+}\right] .-\mathrm{C}_{10} \mathrm{H}_{14} \mathrm{O}$ (150.1) calcd for: C 79.96, H 9.39; found: C 79.71, H 9.14

\section{3,9-decadiynl methansulfonate (113)}

$4.2 \mathrm{ml}$ (54 mmol) of methyl sulfonyl chloride was added at $-10{ }^{\circ} \mathrm{C}$ to mixture of $5.4 \mathrm{~g}$ (36

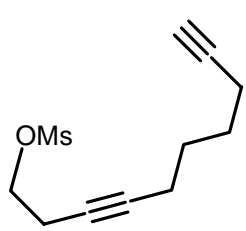
mmol) of 3,9-decadiyn-1-ol (112), $10 \mathrm{ml}$ (72 mmol) of triethyl amine $\left(\mathrm{Et}_{3} \mathrm{~N}\right)$ and $120 \mathrm{ml}$ of dichloromethane. After stirring for $12 \mathrm{~h}$ at -10 ${ }^{\circ} \mathrm{C}$, the reaction mixture was poured into $120 \mathrm{ml}$ of water, the two layers were separated, and the aqueous layer was extracted with $(30 \times 3 \mathrm{ml})$ of dichloromethane. The combined organic phases were dried $\left(\mathrm{MgSO}_{4}\right)$, concentrated and the residue was purified by column chromatography (120 g silica gel , 2:1 pentane/diethyl ether) to afford $7 \mathrm{~g}(85 \%)$ of a yellowish liquid. $\left(\mathrm{R}_{\mathrm{f}}=0.6,1: 1\right.$ 
pentane/diethyl ether).-IR (Film): $v=3289 \mathrm{~cm}^{-1}$, 3026, 2940, 2856, 2115, 1734, 1356, 1175, 964, 904, 801, 649.- ${ }^{1} \mathrm{H}-\mathrm{NMR}\left(250 \mathrm{MHz}, \mathrm{CDCl}_{3}\right): \delta=1.54-1.67$ (m, $4 \mathrm{H}, 6,7-$ H), $1.94\left(\mathrm{t},{ }^{4} \mathrm{~J}=2.7 \mathrm{~Hz}, 1 \mathrm{H}, 10-\mathrm{H}\right), 2.13-2.23$ (m, $4 \mathrm{H}, 5$, 8-H), 2.6 (m, $\left.2 \mathrm{H}, 2-\mathrm{H}\right), 3.03$ (s, $\left.3 \mathrm{H}, \mathrm{CH}_{3} \mathrm{SO}_{3}\right), 4.25$ (t, $\left.{ }^{3} \mathrm{~J}=6.78 \mathrm{~Hz}, 2 \mathrm{H}, 1-\mathrm{H}\right) .-{ }^{13} \mathrm{C}-\mathrm{NMR}\left(62.5 \mathrm{MHz}, \mathrm{CDCl}_{3}, \mathrm{DEPT}\right)$ : $\delta=17.90$ (-, C-2), 18.12 (-, C-5), 20.00 (-, C-8), 27.41 (-, C-6*), 27.58 (-, C-7*), 37.61 (+, $\mathrm{CH}_{3} \mathrm{SO}_{3}$ ), 67.85 (-, C-1), 68.51 (C quart, C-10), 74.50 (C quart, C-3), 82.43 (C $\mathrm{C}_{\text {quart }}$,

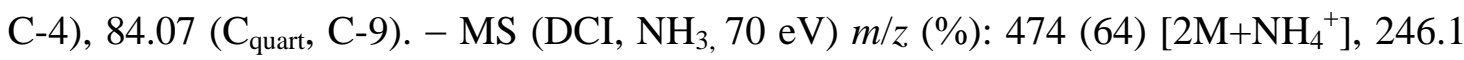
(100) $\left[\mathrm{M}+\mathrm{NH}_{4}^{+}\right] .-\mathrm{C}_{11} \mathrm{H}_{16} \mathrm{O}_{3} \mathrm{~S}$ (228.1) calcd for: C 57.87, H 7.06; found: C 57.97, H 6.91

Dimethyl 2-(3',9'-decadiynyl)malonate (114-COOMe) (E = COOMe)

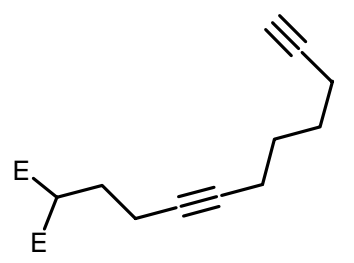

By adapting GP3B, $8.1 \mathrm{~g}$ (61 mmol) of dimethyl malonate was added at $50{ }^{\circ} \mathrm{C}$, dropwise, to a suspension of $2.45 \mathrm{~g}$ (61 mmol) of sodium hydride (60\% oil suspension) in $200 \mathrm{ml}$ of DMF. The resulting clear solution had been transferred into a mixture of $7 \mathrm{~g}$ (30 mmol) of 3,9-decadiynl methansulfonate , $5.1 \mathrm{~g}$ of potassium iodide (30 mmol) and $200 \mathrm{ml}$ of THF and the resulting reaction mixture was refluxed at $70{ }^{\circ} \mathrm{C}$ for $18 \mathrm{~h}$. The reaction mixture was then treated with $200 \mathrm{ml}$ of saturated solution of ammonium chloride $\left(\mathrm{NH}_{4} \mathrm{Cl}\right)$, the two layers were separated and the aqueous layer was extracted with $(3 \times 100 \mathrm{ml})$ of diethyl ether. The combined organic phases were dried $\left(\mathrm{MgSO}_{4}\right)$, concentrated, and the resulting residue was purified by azeotropic kugelrohr distillation ( at $170{ }^{\circ} \mathrm{C}, 0.1 \mathrm{~mm}$ ) after adding 3 drops of methylal to produce $6.7 \mathrm{~g}(83 \%)$ of a colorless oil. An analytical sample was further purified by column chromatography (silica gel, 5:1 pentane/diethyl ether). $\left(\mathrm{R}_{\mathrm{f}}=0.16\right.$, 5:1 pentane/diethyl ether).-IR (Film): $v=$ $3304 \mathrm{~cm}^{-1}$, 3004, 2955, 2865, 2843, 2116, 1762, 1728, 1433, 1360, 1250, 1150, 1050, 632.- ${ }^{1} \mathrm{H}-\mathrm{NMR}\left(250 \mathrm{MHz}, \mathrm{CDCl}_{3}\right): \delta=1.61\left(\mathrm{~m}, 4 \mathrm{H}, 6^{\prime}\left(7^{\prime}\right)-\mathrm{H}\right), 1.94\left(\mathrm{t},{ }^{4} \mathrm{~J}=2.7 \mathrm{~Hz}, 1\right.$ H, 10'-H), 2.08 (q, ${ }^{3} J=6.4$ Hz, 2 H, $\left.1^{\prime}-H\right), 2.15-2.23$ (m, 6 H, 2'(5', $\left.\left.8^{\prime}\right)-H\right), 3.61$ (t, ${ }^{3} J=$ $7.2 \mathrm{~Hz}, 1 \mathrm{H}, 2-\mathrm{H}), 3.74$ (s, $\left.3 \mathrm{H}, \mathrm{COOCH}_{3}\right) \cdot-{ }^{13} \mathrm{C}-\mathrm{NMR}\left(62.5 \mathrm{MHz}, \mathrm{CDCl}_{3}, \mathrm{DEPT}\right): \delta=$ 16.72 (-, C-2'), 17.94 (-, C-5'), 18.20 (-, C-8'), 27.44 (-, C-1'), 27.83 (-, C-6"*), 28.02 $\left(-, \mathrm{C}^{\prime} \mathrm{I}^{*}\right), 50.27(+, \mathrm{C}-2), 52.58\left(+, \mathrm{COOCH}_{3}\right), 68.39$ (+, C-10'), $78.19\left(\mathrm{C}_{\text {quart }}, \mathrm{C}-3^{\prime}\right)$, 
81.26 ( $\mathrm{C}_{\text {quart, }}$ C-4'), 83.30 ( $\mathrm{C}_{\text {quart, }}$ C-9'), $169.59\left(\mathrm{C}_{\text {quart }}, \mathrm{COOCH}_{3}\right) .-\mathrm{MS}\left(\mathrm{DCI}, \mathrm{NH}_{3}, 70\right.$ eV) $m / z(\%): 282$ (100) [M+NH$\left.{ }_{4}^{+}\right], 236$ (2), 206 (4), 167 (8), 150 (8).- $\mathrm{C}_{15} \mathrm{H}_{20} \mathrm{O}_{4}$ (264.3) calcd for: C 68.16, H 7.63; found: C 68.15, H 7.43

Diethyl 2-(3',9'-decadiynyl)malonate (114-COOEt) (E = COOEt)

By following the same procedure for preparing the dimethyl derivative, afforded (75\%) of colorless oil. $\left(\mathrm{R}_{\mathrm{f}}=0.15\right.$, 5:1 pentane/diethyl ether). ${ }^{1} \mathrm{H}-\mathrm{NMR}\left(250 \mathrm{MHz}, \mathrm{CDCl}_{3}\right): \delta=$ $1.26\left(\mathrm{t},{ }^{3} \mathrm{~J}=7.1 \mathrm{~Hz}, 6 \mathrm{H}, \mathrm{COOCH}_{2} \mathrm{CH}_{3}\right), 1.60$ (m, $\left.4 \mathrm{H}, 6^{\prime}\left(7^{\prime}\right)-\mathrm{H}\right), 1.94\left(\mathrm{t},{ }^{4} \mathrm{~J}=2.7 \mathrm{~Hz}, 1 \mathrm{H}\right.$, 10'-H), 2.07 (m, 2 H, 1'-H), $2.17-2.24$ (m, 6 H, 2'(5',8')-H), 3.55 (t, ${ }^{3} J=7.3$ Hz, 1 H, 2$\mathrm{H}), 4.18\left(\mathrm{q},{ }^{3} \mathrm{~J}=7.1 \mathrm{~Hz}, 4 \mathrm{H}, \mathrm{COOCH}_{2} \mathrm{CH}_{3}\right) \cdot-{ }^{13} \mathrm{C}-\mathrm{NMR}\left(62.5 \mathrm{MHz}, \mathrm{CDCl}_{3}, \mathrm{DEPT}\right): \delta=$ 14.07 (+, $\mathrm{COOCH}_{2} \mathrm{CH}_{3}$ ), 16.71 (-, C-2'), 17.92 (-, C-5'), 18.19 (-, C-8'), 27.44 (-, C-1'), $27.83\left(-, \mathrm{C}^{\prime *}{ }^{*}\right), 27.95$ (-, C-7' *), 50.67 (+, C-2), 61.39 (-, $\mathrm{COOCH}_{2} \mathrm{CH}_{3}$ ), 68.38 (+, C-

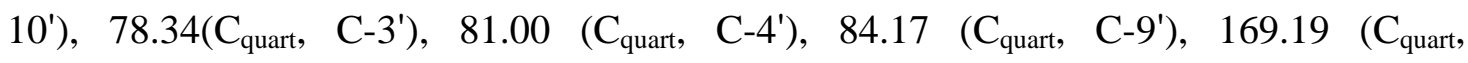
$\mathrm{COOCH}_{2} \mathrm{CH}_{3}$ ).- MS (DCI, $\left.\mathrm{NH}_{3}, 70 \mathrm{eV}\right) \mathrm{m} / \mathrm{z}(\%): 602$ (17) $\left[2 \mathrm{M}+\mathrm{NH}_{4}{ }^{+}\right], 310$ (100) $\left[\mathrm{M}+\mathrm{NH}_{4}^{+}\right], 293(7)\left[\mathrm{M}+\mathrm{H}^{+}\right] .-\mathrm{C}_{17} \mathrm{H}_{24} \mathrm{O}_{4}(292.1)$

Dimethyl 2-(2' '-bromoallyl)-2-(3',9'-decadiynyl)malonate (115-COOMe) (E = COOMe) $6.4 \mathrm{~g}$ (23.79 mmol) of Dimethyl 2-(3',9'-decadiynyl)malonate (114) was added at $50{ }^{\circ} \mathrm{C}$, $\mathrm{H}_{\mathrm{Br}} \quad \mathrm{II}$ dropwise, to a suspension of $0.95 \mathrm{~g}$ (23.79 mmol) of sodium hydride in $90 \mathrm{ml}$ of 1,2-dimethoxyethane (DME). To the
resulting mixture were added $7.13 \mathrm{~g}$ (35.68 mmol) of 2,3dibromopropene and $10 \mathrm{ml}$ of DMF. After refluxing at $70{ }^{\circ} \mathrm{C}$ for $20 \mathrm{~h}$, the reaction mixture was allowed to cool, treated with $120 \mathrm{ml}$ of water, and extracted with $(5 \times 50 \mathrm{ml})$ of diethyl ether. The combined organic phases were dried $\left(\mathrm{MgSO}_{4}\right)$, concentrated, and the produced crude material was purified by column chromatography (200 g silica gel, 5:4 pentane/dichloromethane) to afford $7.8 \mathrm{~g}(85 \%)$ of a colorless oil. $\left(\mathrm{R}_{\mathrm{f}}=0.72,5: 4\right.$ pentane/dichloromethane).-IR (Film) $: v=3311 \mathrm{~cm}^{-1}, 2928,2845,2116,1740,1624$, 1464, 1378, 1273, 1200, 1153, 898, 741.- ${ }^{1} \mathrm{H}-\mathrm{NMR}\left(250 \mathrm{MHz}, \mathrm{CDCl}_{3}\right): \delta=1.59(\mathrm{~m}, 4$ H, 6' (7')-H), 1.94 (t, $\left.{ }^{4} \mathrm{~J}=1.96 \mathrm{~Hz}, 1 \mathrm{H}, 10^{\prime}-\mathrm{H}\right), 2.08-2.26$ (m, 8 H, $\left.1^{\prime}\left(2^{\prime}, 5^{\prime}, 8^{\prime}\right)-\mathrm{H}\right), 3.16$ 
(s, $2 \mathrm{H}, 1$ 1"-H), 3.73 (s, $6 \mathrm{H}, \mathrm{COOCH}_{3}$ ), 5.59 (d, $\left.{ }^{2} J=1.78 \mathrm{~Hz}, 1 \mathrm{H}, 3^{\prime \prime}-\mathrm{H}\right), 5.67$ (d, ${ }^{2} J=$ $1.67 \mathrm{~Hz}, 1 \mathrm{H}, 3$ "-H).- ${ }^{13} \mathrm{C}-\mathrm{NMR}$ (62.5 MHz, $\mathrm{CDCl}_{3}$, DEPT): $\delta=14.26$ (-, C-2'), 17.94 (-, C-5'), 18.26 (-, C-8'), $27.48\left(-, \mathrm{C}^{\prime \prime *}\right), 27.79$ (-, C-7 $\left.{ }^{\prime *}\right), 31.15$ (-, C-1'), 43.19 (-, C1"), $52.74\left(+, \mathrm{COOCH}_{3}\right), 56.45$ ( $\left.\mathrm{C}_{\text {quart }}, \mathrm{C}-2\right), 68.40\left(\mathrm{C}_{\text {quart }}, \mathrm{C}-10\right.$ '), $78.65\left(\mathrm{C}_{\text {quart }}, \mathrm{C}-3^{\prime}\right)$, 80.41 ( $\mathrm{C}_{\text {quart }}, \mathrm{C}-4$ '), 84.20 ( $\mathrm{C}_{\text {quart }}, \mathrm{C}-9$ '), 122.08 (-, C-3"), 126.83 ( $\left.\mathrm{C}_{\text {quart }}, \mathrm{C}-2^{\prime \prime}\right), 170.54$ $\left(\mathrm{C}_{\text {quart }}, \mathrm{COOCH}_{3}\right) .-\mathrm{MS}\left(\mathrm{DCI}, \mathrm{NH}_{3}, 70 \mathrm{eV}\right) \mathrm{m} / \mathrm{z}(\%): 784$ (45) $\left[2 \mathrm{M}+\mathrm{NH}_{4}^{+}\right], 400 / 402$ (100/98) [(M-H)+NH$\left.{ }_{4}^{+}\right], 383 / 385(9 / 9)\left[\mathrm{M}^{+}+\mathrm{H}\right], 303(8)\left[\mathrm{M}^{+}-\mathrm{Br}\right] .-\mathrm{C}_{18} \mathrm{H}_{23} \mathrm{BrO}_{4}(383.2)$ calcd for: C 56.41, H 6.05; found: C 56.70, H 5.82

Diethyl 2-(2' '-bromoallyl)-2-(3',9'-decadiynyl)malonate (115-COOEt) (E = COOEt)

The same procedure for preparing the dimethyl derivative was followed to afford $(77 \%)$ of a colorless oil. $\left(\mathrm{R}_{\mathrm{f}}=0.72\right.$, 5:4 pentane/dichloromethane). ${ }^{1} \mathrm{H}-\mathrm{NMR}\left(250 \mathrm{MHz}, \mathrm{CDCl}_{3}\right)$ : $\delta=1.25\left(\mathrm{t},{ }^{3} J=6.5 \mathrm{~Hz}, 6 \mathrm{H}, \mathrm{COOCH}_{2} \mathrm{CH}_{3}\right), 1.59\left(\mathrm{~m}, 4 \mathrm{H}, 6^{\prime}\left(7^{\prime}\right)-\mathrm{H}\right), 1.94\left(\mathrm{t},{ }^{4} J=1.96\right.$ Hz, 1 H, 10'-H), $2.10-2.22$ (m, 8 H, 1'(2',5',8' )- H), 3.15 (s, 2 H, 1"-H), 4.18 (q, ${ }^{3} J=$ $6.55 \mathrm{~Hz}, 4 \mathrm{H}, \mathrm{COOCH}_{2} \mathrm{CH}_{3}$ ), 5.58 (d, $\left.{ }^{2} J=1.75 \mathrm{~Hz}, 1 \mathrm{H}, 3^{\prime \prime}-\mathrm{H}\right), 5.67$ (d, ${ }^{2} J=1 \mathrm{~Hz}, 1 \mathrm{H}$, 3"-H).- ${ }^{13} \mathrm{C}-\mathrm{NMR}\left(62.5 \mathrm{MHz}, \mathrm{CDCl}_{3}, \mathrm{DEPT}\right): \delta=13.94$ (+, $\left.\mathrm{COOCH}_{2} \mathrm{CH}_{3}\right), 14.21$ (-, C$\left.2^{\prime}\right), 17.94$ (-, C-5'), 18.25 (-, C-8'), 27.48 (-, C-6 $\left.{ }^{\prime *}\right), 27.80$ (-, C-7'*), 31.02 (-, C-1'), 42.96 (-, C-1"), 56.46 ( $\left.\mathrm{C}_{\text {quart }}, \mathrm{C}-2\right), 61.65$ (-, $\left.\mathrm{COOCH}_{2} \mathrm{CH}_{3}\right), 68.38$ ( $\mathrm{C}_{\text {quart }}, \mathrm{C}-10$ '), 78.81 ( $\left.\mathrm{C}_{\text {quart }}, \mathrm{C}-3^{\prime}\right), 80.28$ ( $\left.\mathrm{C}_{\text {quart }}, \mathrm{C}-4^{\prime}\right), 84.20$ ( $\left.\mathrm{C}_{\text {quart }}, \mathrm{C}-9^{\prime}\right), 121.89$ (-, C-3"), 127.06 ( $\mathrm{C}_{\text {quart }}, \mathrm{C}-$ 2"), $170.11\left(\mathrm{C}_{\text {quart }}, \mathrm{COOCH}_{2} \mathrm{CH}_{3}\right)$. - MS (DCI, $\left.\mathrm{NH}_{3}, 70 \mathrm{eV}\right) \mathrm{m} / \mathrm{z}$ (\%): 840 (58) $\left[2 \mathrm{M}+\mathrm{NH}_{4}^{+}\right], \quad 428 / 430 \quad(100 / 98) \quad\left[(\mathrm{M}-\mathrm{H})+\mathrm{NH}_{4}^{+}\right], \quad 411 / 413 \quad(9 / 9) \quad\left[\mathrm{M}^{+}\right], \quad 350 \quad$ (2) $\left[(\mathrm{M}-\mathrm{Br})+\mathrm{NH}_{4}^{+}\right], 331(8)\left[(\mathrm{M}-\mathrm{H})^{+}-\mathrm{Br}\right] .-\mathrm{C}_{20} \mathrm{H}_{27} \mathrm{BrO}_{4}(411.1)$ 
11,11-dimethyl-1-methyl 13-bromo-13-tetradecen-1,7-diyne-1,11,11-tricarboxylate (110COOMe $)(\mathrm{E}=\mathrm{COOMe})$

By using LDA.

By adapting GP6, a solution of LDA (14.8 mmol) in $25 \mathrm{ml}$ THF (prepared by dropwise addition, at $-78{ }^{\circ} \mathrm{C}$, of $1.5 \mathrm{~g}$ of diisopropylamine to a solution of<smiles>C=C(Br)CCC#CCCCCC#CC(C)=O</smiles>
$10 \mathrm{ml}$ (15.6 mmol) of n-butyl lithium (1.56M in hexane) in 25 $\mathrm{ml}$ THF and stirring for $30 \mathrm{~min}$ ) was added dropwise, at -78 ${ }^{\circ} \mathrm{C}$, to a solution of $5.4 \mathrm{~g}(14.2 \mathrm{mmol})$ of dimethyl 2-(2"bromoallyl)-2-(3',9'-decadiynyl)malonate in $25 \mathrm{ml}$ THF. After stirring for $30 \mathrm{~min}, 2.48 \mathrm{ml}(13.7 \mathrm{mmol})$ of HMPA and $10.8 \mathrm{ml}(142 \mathrm{mmol})$ of chloromethylformate were added and stirring was continued for $1 \mathrm{~h}$ at $-78{ }^{\circ} \mathrm{C}$ and $2 \mathrm{~h}$ at room temperature. After working up, as described in GP6, the resulting residue was purified by column chromatography (100 g silica gel and using a polarity gradient starting with 8:1 pentane/diethyl ether till the starting materials were removed; then with 6:1 pentane/diethyl ether and finally with 4:1 pentane/diethyl ether to elute the product) to afford $2.8 \mathrm{~g}(44 \%)$ of a colorless oil. $\left(\mathrm{R}_{\mathrm{f}}=0.36,4: 1\right.$ pentane/diethyl ether).

\section{By using n-butyl lithium}

The above procedure was followed, but instead of using LDA, n-butyl lithium was used. The compound was separated from a complicated mixture of byproducts by using column chromatography (silica gel, 8:1 pentane/diethyl ether ) in a 20\% yield.-IR (Film): $v=$ $3002 \mathrm{~cm}^{-1}$, 2953, 2865, 2236, 1736, 1708, 1625, 1433, 1274, 1179, 1152, 1080, 902, 753, 591.- ${ }^{1} \mathrm{H}-\mathrm{NMR}\left(250 \mathrm{MHz}, \mathrm{CDCl}_{3}\right): \delta=1.53-1.72(\mathrm{~m}, 4 \mathrm{H}, 4(5)-\mathrm{H}), 2.01-2.24(\mathrm{~m}, 6$ H, 6(9,10)-H), 2.34 (t, $\left.{ }^{3} J=6.80 \mathrm{~Hz}, 2 \mathrm{H}, 3-\mathrm{H}\right), 3.15$ (s, $\left.2 \mathrm{H}, 12-\mathrm{H}\right), 3.72$ (s, $3 \mathrm{H}$, $\mathrm{COOCH}_{3}$ ), 3.74 (s, $3 \mathrm{H}, \mathrm{COOCH}_{3}$ ), $5.58\left(\mathrm{~d},{ }^{2} J=1.78 \mathrm{~Hz}, 1 \mathrm{H}, 14-\mathrm{H}\right), 5.66$ (d, ${ }^{2} J=1.62$ Hz, 1H, 14-H). ${ }^{13}$ C-NMR ( 62.5 MHz, $\mathrm{CDCl}_{3}$, DEPT): $\delta=14.24$ (-, C-9), 18.20 (-, C-6), 18.21 (-, C-3), 26.50 (-, C-5), 27.75 (-, C-4), 31.12 (-, C- 10), 43.19 (-, C-12), 52. 57 (+, $\left.\mathrm{COOCH}_{3}\right), 52.74\left(+, \mathrm{COOCH}_{3}\right), 56.43\left(\mathrm{C}_{\text {quart }}, \mathrm{C}-11\right), 73.02\left(\mathrm{C}_{\text {quart }}, \mathrm{C}-1\right), 78.93\left(\mathrm{C}_{\text {quart }}\right.$, C-8), 80.03 ( $\left.\mathrm{C}_{\text {quart }}, \mathrm{C}-7\right), 89.30$ ( $\left.\mathrm{C}_{\text {quart }}, \mathrm{C}-2\right), 122.09$ (-, C-14), 126.79 ( $\mathrm{C}_{\text {quart }}, \mathrm{C}-13$ ), $154.18\left(\mathrm{C}_{\text {quart }}, \mathrm{COOCH}_{3}\right), 170.52\left(\mathrm{C}_{\text {quart }}, \mathrm{COOCH}_{3}\right) .-\mathrm{MS}\left(\mathrm{DCI}, \mathrm{NH}_{3}, 70 \mathrm{eV}\right) \mathrm{m} / \mathrm{z}(\%)$ : 
460/458 (100/96) [(M-H)+NH $\left.{ }_{4}^{+}\right], 340$ (4) , 208 (4). $-\mathrm{C}_{20} \mathrm{H}_{25} \mathrm{BrO}_{6}$ (441.3) calcd for: $\mathrm{C}$ 54.43, H 5.71; found: C 54.43, H 5.41

11,11-diethyl-1-methyl 13-bromo-13-tetradecen-1,7-diyne-1,11,11-tricarboxylate (110COOEt $)(\mathrm{E}=\mathrm{COOEt})$

The same procedure for preparing the dimethyl derivative was followed to afford (41\%) of a colorless oil.$\left(\mathrm{R}_{\mathrm{f}}=0.34,4: 1\right.$ pentane/diethyl ether). ${ }^{1} \mathrm{H}-\mathrm{NMR}\left(250 \mathrm{MHz}, \mathrm{CDCl}_{3}\right): \delta=$ 1.25 (t, ${ }^{3} \mathrm{~J}=7.10 \mathrm{~Hz}, 6 \mathrm{H}, \mathrm{COOCH}_{2} \mathrm{CH}_{3}$ ), $1.56-1.69$ (m, $\left.4 \mathrm{H}, 4(5)-\mathrm{H}\right), 2.11-2.24$ (m, 6 H, 6(9,10)-H), 2.35 (t, $\left.{ }^{3} J=6.80 \mathrm{~Hz}, 2 \mathrm{H}, 3-\mathrm{H}\right), 3.15$ (s, $\left.2 \mathrm{H}, 12-\mathrm{H}\right), 3.74(\mathrm{~s}, 3 \mathrm{H}$, $\left.\mathrm{COOCH}_{3}\right), 4.18\left(\mathrm{q},{ }^{3} J=7.11 \mathrm{~Hz}, 4 \mathrm{H}, \mathrm{COOCH}_{2} \mathrm{CH}_{3}\right), 5.58\left(\mathrm{~d},{ }^{2} J=1.78 \mathrm{~Hz}, 1 \mathrm{H}, 14-\mathrm{H}\right)$, $5.67\left(\mathrm{~d},{ }^{2} J=1.62 \mathrm{~Hz}, 1 \mathrm{H}, 14-\mathrm{H}\right) .-{ }^{13} \mathrm{C}-\mathrm{NMR}\left(62.5 \mathrm{MHz}, \mathrm{CDCl}_{3}, \mathrm{DEPT}\right): \delta=13.94(+$, $\mathrm{COOCH}_{2} \mathrm{CH}_{3}$ ), 14.20 (-, C-9), 18.18 (-, C-6), 18.21 (-, C-3), 26.51 (-, C-5), 27.76 (-, C-4), 31.00 (-, C- 10), 42.97 (-, C-12), 52.57 (+, $\left.\mathrm{COOCH}_{3}\right), 56.45$ (C $\left.\mathrm{C}_{\text {quart }}, \mathrm{C}-11\right), 61.66$ (-, $\left.\mathrm{COOCH}_{2} \mathrm{CH}_{3}\right), 73.02$ ( $\left.\mathrm{C}_{\text {quart }}, \mathrm{C}-1\right), 79.09$ (C $\left.\mathrm{C}_{\text {quart }}, \mathrm{C}-8\right), 79.90$ ( $\left.\mathrm{C}_{\text {quart }}, \mathrm{C}-7\right), 89.33\left(\mathrm{C}_{\text {quart }}\right.$, C-2), 121.91 (-, C-14), 127.04 (C quart, C-13), 154.20 (C quart, $\left.\mathrm{COOCH}_{3}\right), 170.09$ (C quart, $\mathrm{COOCH}_{2} \mathrm{CH}_{3}$ ). - MS (DCI, $\mathrm{NH}_{3}, 70 \mathrm{eV}$ ) m/z (\%): 956 (0.1) [2M+NH$\left.{ }_{4}^{+}\right], 486 / 488$ (97/100) $\left[\mathrm{M}+\mathrm{NH}_{4}^{+}\right], 408(25)\left[(\mathrm{M}-\mathrm{Br})+\mathrm{NH}_{4}^{+}\right] .-\mathrm{C}_{22} \mathrm{H}_{29} \mathrm{BrO}_{6}(469.0)$

2'-bromoallyl 3,9-decadiynyl ether (133)

$3.8 \mathrm{~g}$ (25.25 mmol) of 3,9-decadiyn-1-ol (112) was added at $70{ }^{\circ} \mathrm{C}$,<smiles>C#CCCCC#CCCOCC(=C)Br</smiles>
dropwise, to a suspension of $1.5 \mathrm{~g}(38 \mathrm{mmol})$ of sodium hydride (60\% oil suspension) in $60 \mathrm{ml}$ of THF. To the resulting mixture was added $7.6 \mathrm{~g}$ (38 mmol) of 2,3-dibromopropene and refluxed at $70{ }^{\circ} \mathrm{C}$ for 12 h. After cooling, the reaction mixture was quenched with $80 \mathrm{ml}$ of a saturated solution of ammonium chloride and extracted with $(4 \times 40 \mathrm{ml})$ of diethyl ether. The combined ether layers were dried $\left(\mathrm{MgSO}_{4}\right)$ and concentrated. The resulting residue was purified by column chromatography (100 g silica gel and 20:1 pentane/diethyl ether) to afford $2.9 \mathrm{~g}(42 \%)$ of a colorless oil. $\quad\left(\mathrm{R}_{\mathrm{f}}=0.40,10: 1\right.$ pentane/diethyl ether).-IR (Film): $v=3304 \mathrm{~cm}^{-1}, 2948,2907,2864,2116,1735,1640,1434,1333,1110,895,638 .{ }^{1} \mathrm{H}-$ NMR (250 MHz, $\mathrm{CDCl}_{3}$ ): $\delta=1.57-1.65$ (m, $\left.4 \mathrm{H}, 6(7)-\mathrm{H}\right), 1.94\left(\mathrm{t},{ }^{4} \mathrm{~J}=2.69 \mathrm{~Hz}, 1 \mathrm{H}\right.$, 
10-H), 2.15 - 2.23 (m, 4 H, 5(8)-H), $2.43-2.49$ (m, 2 H, 2-H), 3.56 (t, ${ }^{3} J=7.00 \mathrm{~Hz}, 2 \mathrm{H}$, 1-H), 4.12 (s, 2 H, 1'-H), 5.61 (dd, $\left.{ }^{2} J=1.75 \mathrm{~Hz},{ }^{4} J=0.64 \mathrm{~Hz}, 1 \mathrm{H}, 3^{\prime}-\mathrm{H}\right), 5.95$ (d, ${ }^{2} J=$ $\left.1.36 \mathrm{~Hz}, 1 \mathrm{H}, 3^{\prime}-\mathrm{H}\right) .{ }^{13} \mathrm{C}-\mathrm{NMR}$ ( $62.5 \mathrm{MHz}, \mathrm{CDCl}_{3}$, DEPT): $\delta=17.93$ (-, C-5 $\left.{ }^{*}\right), 18.02$ (-, C-8*), 20.10 (-, C-2), 27.47 (-, C-6 $\left.{ }^{* *}\right), 27.79\left(-, \mathrm{C}^{*}{ }^{* *}\right), 68.36$ (+, C-10), 69.07 (-, C-1),

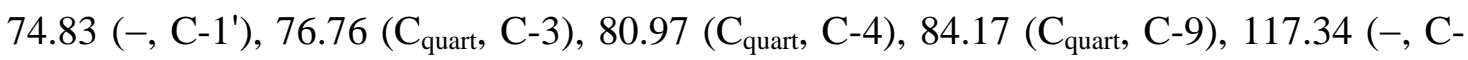

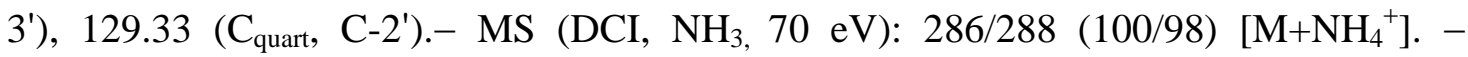
$\mathrm{C}_{13} \mathrm{H}_{17} \mathrm{BrO}$ (269.2) calcd for: C 58.01, H 6.37; found: C 58.32, H 6.25

Methyl 11-(2'-bromoallyloxy)-2,8-undecadiynoate (132)

By adapting GP6, a solution of LDA $(9.1 \mathrm{mmol})$ in $15 \mathrm{ml}$ THF<smiles>C=C(Br)COCC#CCCCCC#CC(C)=O</smiles>
(prepared by dropwise addition, at $-78{ }^{\circ} \mathrm{C}$, of $0.92 \mathrm{~g}$ of diisopropylamine to a solution of $4.5 \mathrm{ml}(9 \mathrm{mmol})$ of n-butyl lithium (2 $\mathrm{M}$ in hexane) in $15 \mathrm{ml}$ THF and stirring for $30 \mathrm{~min}$ ) was added, dropwise, at $-78{ }^{\circ} \mathrm{C}$ to a solution of $2.3 \mathrm{~g}$ (8.5 mmol) of $2^{\prime}-$ bromoallyl 3,9-decadiynyl ether (133) in $15 \mathrm{ml}$ THF. After stirring for $30 \mathrm{~min}, 1.5 \mathrm{ml}$ (8.2 mmol) of HMPA and $6.4 \mathrm{ml}(81.6 \mathrm{mmol})$ of chloromethylformate were added and stirring was continued for $1 \mathrm{~h}$ at $-78{ }^{\circ} \mathrm{C}$ and $2 \mathrm{~h}$ at room temperature. After working up, as described in GP6, the resulting residue was purified by column chromatography (80g silica gel and 10:1 pentane/diethyl ether) to afford $1.9 \mathrm{~g}(68 \%)$ of a colorless oil. $\left(\mathrm{R}_{\mathrm{f}}\right.$ =0.12, 20:1 pentane/diethyl ether).-IR (Film): $v=3409 \mathrm{~cm}^{-1}$, 3305, 2954, 2866, 2235, 1719, 1639, 1434, 1251, 1109, 1078, 894, 752, 670.- ${ }^{1} \mathrm{H}-\mathrm{NMR}\left(250 \mathrm{MHz}, \mathrm{CDCl}_{3}\right): \delta=$ 1.56 - 1.72 (m, 4 H, 5(6)-H), 2.15 - 2.21 (m, 2H, 7 H), 2.35 (t, ${ }^{3} J=6.83$ Hz, 2 H, 4-H), $2.41-2.49$ (m, 2 H, 10-H), 3.55 (t, $\left.{ }^{3} J=6.91 \mathrm{~Hz}, 11-\mathrm{H}\right), 3.75$ (s, $3 \mathrm{H}, \mathrm{COOCH}_{3}$ ), 4.12 (dd, $\left.{ }^{2} J=2.26 \mathrm{~Hz},{ }^{4} J=1.05 \mathrm{~Hz}, 2 \mathrm{H}, 1^{\prime}-\mathrm{H}\right), 5.61\left(\mathrm{dd},{ }^{2} J=1.75 \mathrm{~Hz},{ }^{4} J=0.95 \mathrm{~Hz}, 1 \mathrm{H}, 3^{\prime}-\mathrm{H}\right)$, 5.94 (dd, $\left.{ }^{2} J=2.69 \mathrm{~Hz},{ }^{4} J=1.28 \mathrm{~Hz}, 1 \mathrm{H}, 3{ }^{1}-\mathrm{H}\right) \cdot-{ }^{13} \mathrm{C}-\mathrm{NMR}\left(62.5 \mathrm{MHz}, \mathrm{CDCl}_{3}, \mathrm{DEPT}\right): \delta$ $=18.16\left(-, \mathrm{C}^{*}\right), 18.21\left(-, \mathrm{C}-4^{*}\right), 20.09$ (-, C-10), 26.52 (-, C-6), 27.76 (-, C-5), $52.52\left(+, \mathrm{COOCH}_{3}\right), 69.02$ (-, C-11), 74.84 (-, C-1'), $77.08\left(\mathrm{C}_{\text {quart, }}, \mathrm{C}-2^{* *}\right), 77.17$ $\left(\mathrm{C}_{\text {quart }}, \mathrm{C}-9^{* *}\right), 80.58\left(\mathrm{C}_{\text {quart, }} \mathrm{C}-8\right), 89.28$ ( $\left.\mathrm{C}_{\text {quart }}, \mathrm{C}-3\right), 117.37$ (-, C-3'), 129.33 ( $\mathrm{C}_{\text {quart }}, \mathrm{C}-$ 
2'), $159.94\left(\mathrm{C}_{\text {quart }}, \mathrm{COOCH}_{3}\right)$.- MS (DCI, $\left.\mathrm{NH}_{3}, 70 \mathrm{eV}\right): 344 / 346$ (98/100) [(M$\left.\mathrm{H})+\mathrm{NH}_{4}^{+}\right] .-\mathrm{C}_{13} \mathrm{H}_{17} \mathrm{BrO}(327.2)$.

Dimethyl 2-(2"'-bromoallyl)-2-(11'-oxo-3',9'-dodecadiynyl)malonate (144)

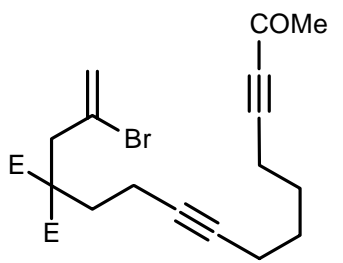

By adapting GP6, a solution of LDA (16.8 mmol) in $30 \mathrm{ml}$ THF (prepared by dropwise addition, at $-78{ }^{\circ} \mathrm{C}$, of $1.7 \mathrm{~g}$ of diisopropylamine to a solution of $7.8 \mathrm{ml}(17.9 \mathrm{mmol})$ of n-butyl lithium (2.3M in hexane) in $30 \mathrm{ml}$ THF and stirring for $30 \mathrm{~min}$ ) was added, dropwise, at $-78{ }^{\circ} \mathrm{C}$ to a solution of $6 \mathrm{~g}(15.7 \mathrm{mmol})$ of dimethyl 2-(2"-bromoallyl)-2-(3',9'-decadiynyl)malonate(115) in $30 \mathrm{ml}$ THF. After stirring for $30 \mathrm{~min}, 2.74 \mathrm{ml}(15.1 \mathrm{mmol})$ of HMPA and $14.8 \mathrm{ml}(157 \mathrm{mmol})$ of acetic anhydride were added and stirring was continued for $1 \mathrm{~h}$ at $-78{ }^{\circ} \mathrm{C}$ and $2 \mathrm{~h}$ at room temperature. The reaction mixture was treated $100 \mathrm{ml}$ water, $50 \mathrm{ml}$ saturated solution of ammonium chloride and extracted with $(4 \times 50 \mathrm{ml})$ of diethyl ether. The combined ether layers were further washed with $50 \mathrm{ml}$ of $0.1 \mathrm{M}$ of potassium hydroxide, $50 \mathrm{ml}$ of water, dried $\left(\mathrm{MgSO}_{4}\right)$ and concentrated. The resulting residue was purified by column chromatography (100 g silica gel and using polarity gradient starting with 8:1 pentane/diethyl ether till the starting materials were removed, then with 6:1 pentane/diethyl ether and finally with 4:1 pentane/diethyl ether to elute the product ) to afford $2.6 \mathrm{~g}$ (40\%) of a colorless oil. $\left(\mathrm{R}_{\mathrm{f}}=0.36\right.$, 4:1 pentane/diethyl ether).-IR (Film): $v=$ $3329 \mathrm{~cm}^{-1}$, 3003, 2953, 2841, 2211, 1725, 1677, 1625, 1434, 1360, 1276, 1247, 1178, 1152, 1082, 902, 738, 559.- H-NMR (250 MHz, $\left.\mathrm{CDCl}_{3}\right): \delta=1.54-1.69$ (m, 4 H, 6'(7')H), 2.08 - 2.25 (m, 6H, 2'(5',8')-H), 2.31 (s, 3 H, COCH $), 2.37$ (t, ${ }^{3} J=6.82 \mathrm{~Hz}, 2 \mathrm{H}, 1^{\prime}-$ H), $3.16\left(\mathrm{~d},{ }^{2} \mathrm{~J}=0.7 \mathrm{~Hz}, 2 \mathrm{H}, 1\right.$ "-H), 3.73 (s, $3 \mathrm{H}, \mathrm{COOCH}_{3}$ ), 5.58 (d, ${ }^{2} J=1.8 \mathrm{~Hz}, 1 \mathrm{H}$, 3"-H), 5.67 (d, $\left.{ }^{2} J=1.73 \mathrm{~Hz}, 1 \mathrm{H}, 3 "-\mathrm{H}\right) . .{ }^{13} \mathrm{C}-\mathrm{NMR}\left(62.5 \mathrm{MHz}, \mathrm{CDCl}_{3}, \mathrm{DEPT}\right): \delta=$ 14.25 (-, C-8'), 18.20 (-, C-2'*), 18.48 (-, C-5'*), 26.68 (-, C-6'), 27.82 (-, C-7'), 31.14 (-, C-1'), 32.77 (+, $\left.\mathrm{COCH}_{3}\right), 43.17$ (-, C-1"), 52.75 (+, $\left.\mathrm{COOCH}_{3}\right), 56.45\left(\mathrm{C}_{\text {quart }}, \mathrm{C}-2\right)$, 78.93( $\left.\mathrm{C}_{\text {quart }}, \mathrm{C}-10^{\prime}\right), 80.05$ ( $\left.\mathrm{C}_{\text {quart }}, \mathrm{C}-3^{\prime}\right), 81.52$ ( $\left.\mathrm{C}_{\text {quart }}, \mathrm{C}-4{ }^{\prime}\right), 93.47$ ( $\mathrm{C}_{\text {quart }}, \mathrm{C}-9$ '), 122.08 
(-, C-3"), $126.80\left(\mathrm{C}_{\text {quart, }} \mathrm{C}-2^{\prime \prime}\right), 170.52\left(\mathrm{C}_{\text {quart }}, \mathrm{COOCH}_{3}\right), 184.93\left(\mathrm{C}_{\text {quart }}, \mathrm{COCH}_{3}\right) .-\mathrm{MS}$ $\left(\mathrm{DCI}, \mathrm{NH}_{3}, 70 \mathrm{eV}\right) \mathrm{m} / \mathrm{z}(\%): 868(0.1)\left[2 \mathrm{M}+\mathrm{NH}_{4}{ }^{+}\right], 442 / 444(93 / 100)\left[(\mathrm{M}-\mathrm{H})+\mathrm{NH}_{4}{ }^{+}\right]$, 364 (52) $\left[(\mathrm{M}-\mathrm{Br})+\mathrm{NH}_{4}{ }^{+}\right], 324$ (36) $\left[(\mathrm{M}-2 \mathrm{COOMe})+\mathrm{NH}_{4}{ }^{+}\right], 282$ (12). $-\mathrm{C}_{20} \mathrm{H}_{25} \mathrm{BrO}_{5}$ (425.3)

15-bromo-13-(tert-butyldimethylsilyloxy)-15-hexadecen-3,9-diyn-2-one (145)

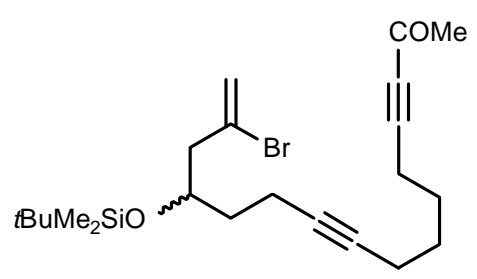

By adapting GP6, a solution of LDA (7 mmol) in 20 $\mathrm{ml}$ THF (prepared by dropwise addition , at $-78{ }^{\circ} \mathrm{C}$, of $0.7 \mathrm{~g}$ of diisopropylamine to a solution of $3.5 \mathrm{ml}(7$ mmol) of n-butyl lithium (2M in hexane) in $20 \mathrm{ml}$ THF and stirring for $30 \mathrm{~min}$ ) was added, dropwise, at $-78{ }^{\circ} \mathrm{C}$ to a solution of $2.5 \mathrm{~g}$ (6.3 $\mathrm{mmol})$ of 2-bromo-4-(tert-butyldimethylsilyloxy1)-1tetradecen-7,13-diyne(117) in $20 \mathrm{ml}$ THF. After stirring for $30 \mathrm{~min}, 1.1 \mathrm{ml}$ (6 mmol) of HMPA and $6 \mathrm{ml}$ (63 mmol) of acetic anhydride were added and stirring was continued for $1 \mathrm{~h}$ at $-78{ }^{\circ} \mathrm{C}$ and $2 \mathrm{~h}$ at room temperature. The reaction mixture was treated $100 \mathrm{ml}$ water, $50 \mathrm{ml}$ saturated solution of ammonium chloride and extracted with $(4 \times 50 \mathrm{ml})$ of diethyl ether. The combined ether layers were dried $\left(\mathrm{MgSO}_{4}\right)$, concentrated, and the resulting residue was purified by column chromatography (70 g silica gel and 20:1 pentane/diethyl ether) to afford $1.7 \mathrm{~g}(61 \%)$ of a colorless oil. $\left(\mathrm{R}_{\mathrm{f}}=0.20,20: 1\right.$ pentane/diethyl ether).-IR (Film): $v=3336 \mathrm{~cm}^{-1}$, 2956, 2929, 2856, 2211, 1678, 1631, 1471, 1433, 1358, 1227, 1077, 1004, 837, 776, 661.- ${ }^{1} \mathrm{H}-\mathrm{NMR}\left(250 \mathrm{MHz}, \mathrm{CDCl}_{3}\right): \delta=$ 0.086 (s, 3 H, TBDMS-H), 0.091 (s, 3 H, TBDMS- H), 0.87 (s, 9 H, TBDMS-H), 1.521.75 (m, 6 H, 6(7,12)-H), 2.18 - 2.24 (m, 4 H, 8(11)-H), 2.31 (s, 3 H, COCH $), 2.37$ (t, ${ }^{3} J$ = 6.8 Hz, $2 \mathrm{H}, 5-\mathrm{H}), 2.51$ (d, $\left.{ }^{3} J=6.4 \mathrm{~Hz}, 1 \mathrm{H}, 14-\mathrm{H}\right), 2.55$ (d, $\left.{ }^{3} J=6.9 \mathrm{~Hz}, 1 \mathrm{H}, 14-\mathrm{H}\right)$, 4.07 (m, $1 \mathrm{H}, 13-\mathrm{H}), 5.43$ (d, $\left.{ }^{2} J=1.5 \mathrm{~Hz}, 1 \mathrm{H}, 16-\mathrm{H}\right), 5.60$ (bs, $\left.1 \mathrm{H}, 16-\mathrm{H}\right) .-{ }^{13} \mathrm{C}-\mathrm{NMR}$ (62.5 MHz, $\left.\mathrm{CDCl}_{3}, \mathrm{DEPT}\right): \delta=-4.62$ (+, TBDMS-C), - 4.39 (+, TBDMS-C), 14.69 (-,

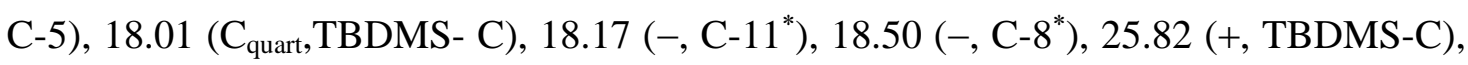
$26.71\left(-, \mathrm{C}^{* * *}\right), 27.99\left(-, \mathrm{C}-6^{* *}\right), 32.74\left(+, \mathrm{COCH}_{3}\right), 35.73(-, \mathrm{C}-12), 49.32(-, \mathrm{C}-14)$, 68.81 (+, C- 13), 79.63 ( $\left.\mathrm{C}_{\text {quart }}, \mathrm{C}-4\right), 80.22$ ( $\left.\mathrm{C}_{\text {quart }}, \mathrm{C}-10\right), 81.51$ ( $\left.\mathrm{C}_{\text {quart }}, \mathrm{C}-9\right), 93.50$ ( $\mathrm{C}_{\text {quart }}$, 
C- 3), 119.16 (-, C-16), 130.79 (C quart, C-15), 210.07 ( $\left.\mathrm{C}_{\text {quart }}, \mathrm{COCH}_{3}\right) .\left(\mathrm{DCI}, \mathrm{NH}_{3}, 70 \mathrm{eV}\right.$ ) m/z (\%): 896 (0.1) [2M+NH$\left.{ }_{4}^{+}\right], 458 / 456(100 / 96)\left[(\mathrm{M}-\mathrm{H})+\mathrm{NH}_{4}{ }^{+}\right], 441 / 439(20 / 19)\left[\mathrm{M}^{+}\right]$, 378 (35) [(M-Br) $\left.+\mathrm{NH}_{4}^{+}\right], 319(15) .-\mathrm{C}_{22} \mathrm{H}_{35} \mathrm{BrO}_{2} \mathrm{Si}(439.5)$.

\section{Palladium-catalyzed Oligocyclizations}

5-(tert-butyldimethylsilyloxy)-9-phenyltricyclo[8.4.0.0 $\left.0^{2,7}\right]$ tetradeca-1,7,9-triene (74)

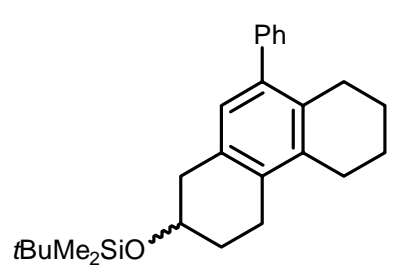

By adapting GP8 method B, $9.48 \mathrm{mg}(0.042 \mathrm{mmol})$ of palladium acetate was added at $80{ }^{\circ} \mathrm{C}$ to a degassed mixture of $28 \mathrm{mg}$ ( $0.10 \mathrm{mmol})$ of triphenylphosphine, $34.4 \mathrm{mg}(0.50$ $\mathrm{mmol})$ of sodium formate, and $200 \mathrm{mg}(0.42 \mathrm{mmol})$ of 1 (13'-bromo-11'-(tert-butyldimethylsilyloxy)-13'-tetradecen1',7'-diynyl)benzene(49) in $5 \mathrm{ml}$ DMF. After stirring from $5 \mathrm{~h}$ at $80{ }^{\circ} \mathrm{C}$, the reaction mixture was poured into $30 \mathrm{ml}$ of water and extracted $(3 \times 20 \mathrm{ml})$ with diethyl ether. The combined ether layers were dried $\left(\mathrm{MgSO}_{4}\right)$, concentrated and the residue was eluted from $20 \times 20 \mathrm{~cm}$ plates coated with thick layer of silica gel (Silica gel $60 \mathrm{PF}_{254}$ containing $\left.\mathrm{CaSO}_{4}\right)$ with 2:1 pentane/dichloromethane. The third fraction $\left(\mathrm{R}_{\mathrm{f}}=0.55,2: 1\right.$ pentane/dichloromethane) from the plates' top afforded $25 \mathrm{mg}$ (15\%) of the title compound as a yellow oil.-IR (Film): $v=3057 \mathrm{~cm}^{-1}, 2927,2856,1462,1251,1095,882$, 773.- ${ }^{1} \mathrm{H}-\mathrm{NMR}\left(250 \mathrm{MHz}, \mathrm{CDCl}_{3}\right.$ ): $\delta=0.11$ (s, $6 \mathrm{H}$, TBDMS-H), 0.92 (s, $9 \mathrm{H}$, TBDMSH), 1.60 - 1.89 (m, 5 H, 3(11,14)-H ), 2.07 (m, 1 H, 14-H), 2.58 (t, ${ }^{3} J=6.35$ Hz, 2 H, 4H), 2.63 - 2.93 (m, 6 H, 6(12,13)-H ), 4.10 (m, 1 H, 5 H), 6.84 (s, 1 H, 8-H), 7.25 - 7.41 (m, $5 \mathrm{H}$, Aromatic-H).- ${ }^{1} \mathrm{H}-\mathrm{NMR}\left(500 \mathrm{MHz}, \mathrm{CDCl}_{3}\right): \delta=0.12$ (s, $\left.6 \mathrm{H}, \mathrm{TBDMS}-\mathrm{H}\right), 0.94$ (s, 9 H, TBDMS-H), 1.60 - 1.72 (m, 2 H, 3 H), 1.76 -1.92 (m, 3H, 11(14)-H), 2.10 (m, 1 H, $14 \mathrm{H}), 2.56$ (t, $\left.{ }^{3} \mathrm{~J}=10 \mathrm{~Hz}, 2 \mathrm{H}, 4-\mathrm{H}\right), 2.58-2.74$ (m, 2H, 13-H), $2.74-2.88$ (m, $3 \mathrm{H}$, 6(12)-H), 2.96 (dd, ${ }^{2} J=4$ Hz, ${ }^{3} J=15$ Hz, 1 H, 6-H), 4.08 (m, 1 H, 5-H), 6.84 (s, 1 H, 8H), 7.25 - 7.40 (m, $5 \mathrm{H}$, Aromatic-H).- ${ }^{13} \mathrm{C}-\mathrm{NMR}\left(150.82 \mathrm{MHz}, \mathrm{CDCl}_{3}, \mathrm{APT}\right): \delta=-$ 4.62 (+, TBDMS-C), - 4.59 (+, TBDMS-C), 18.30 (-, TBDMS-C), 22.90 (-, C-3), 23.15 (-, C-11), 25.87 (-, C-12), 25.95 (+, TBDMS-C), 27.02 (-, C-13), 28.83 (-, C-4), 32.60 (-, C-14), 39.55 (-, C-6), 68.13 (+, C- 5), 126.53 (+, Aromatic-C, rot), 127.91 (+, 
Aromatic-C, rot), 128.12 (+, Aromatic-C, rot), 128.44 (+, Aromatic-C, rot), 128.49 (+, Aromatic-C, rot), 128.52 (+, Aromatic- C, rot), 128.73 (+, Aromatic-C, rot), 129.27 (+, Aromatic-C, rot), 132.22 (-, Aromatic-C), 132.37 (-, Aromatic-C), 133.53 (-, AromaticC), 133.66 (+, Aromatic- C, rot), 133.78 (+, Aromatic-C, rot), 135.22 (-, Aromatic-C), 139.95 (-, Aromatic-C), 142.06 (-, Aromatic-C) .- MS (DCI, $\left.\mathrm{NH}_{3}, 70 \mathrm{eV}\right) \mathrm{m} / \mathrm{z}(\%): 410$ (100) $\left[\mathrm{M}+\mathrm{NH}_{4}{ }^{+}\right], 495(26)\left[\left(\mathrm{M}-\mathrm{CH}_{3}\right)+\mathrm{NH}_{4}{ }^{+}\right], 352(7)\left[(\mathrm{M}+\mathrm{H})-\mathrm{C}\left(\mathrm{CH}_{3}\right)_{3}+\mathrm{NH}_{4}{ }^{+}\right], 296(12)$ $\left[\left(\mathrm{M}-\mathrm{t}-\mathrm{BuMe}{ }_{2} \mathrm{Si}\right)+\mathrm{NH}_{4}^{+}\right], 279$ (16) $\left[(\mathrm{M}-\mathrm{H})-\mathrm{t}-\mathrm{BuMe}_{2} \mathrm{SiO}+\mathrm{NH}_{4}^{+}\right], 263$ (27). $-\mathrm{C}_{26} \mathrm{H}_{36} \mathrm{OSi}$ (392.6) calcd for: C 79.53, H 9.24; found: C 79.41, H 9.08

\section{Diethyl 9-phenyltricyclo[8.4.0.0 $\left.{ }^{2,7}\right]$ tetradeca-1,7,9-triene-5,5-dicarboxylate (73)}

By adapting GP8 method B, $11.25 \mathrm{mg}(0.050 \mathrm{mmol})$ of palladium acetate was added at $80{ }^{\circ} \mathrm{C}$ to a degassed mixture of $33 \mathrm{mg}(0.125 \mathrm{mmol})$ of triphenylphosphine, $40.9 \mathrm{mg}(0.60$<smiles>FC1(F)CCc2c(cc(-c3ccccc3)c3c2CCCC3)C1</smiles>
mmol) of sodium formate, and $244 \mathrm{mg}(0.50 \mathrm{mmol})$ of Diethyl2-(2"bromoallyl)-2-(10'-phenyl-3',9'-decadiynyl)malonate(48) in $5 \mathrm{ml}$ DMF. After stirring from $5 \mathrm{~h}$ at $80{ }^{\circ} \mathrm{C}$, the reaction mixture was poured into $30 \mathrm{ml}$ of water and extracted $(3 \times 20 \mathrm{ml})$ with diethyl ether. The combined ether layers were dried $\left(\mathrm{MgSO}_{4}\right)$, concentrated and the residue was eluted from $20 \times 20 \mathrm{~cm}$ plates coated with thick layer of silica gel (Silica gel $60 \mathrm{PF}_{254}$ containing $\mathrm{CaSO}_{4}$ ) with 5:1 pentane/diethyl ether. The third fraction $\left(R_{f}=0.34\right.$, 5:1 pentane/diethyl ether) from the plates' top afforded $64 \mathrm{mg}$ (40\%) of the title compound as an orange oil .-IR (Film): $v=3057 \mathrm{~cm}^{-} 1,2983,2929,2854,1732$, 1440, 1252, 1180, 1097, 1081, 711, 704.- ${ }^{1} \mathrm{H}-\mathrm{NMR}\left(250 \mathrm{MHz}, \mathrm{CDCl}_{3}\right): \delta=1.21\left(\mathrm{t},{ }^{3} \mathrm{~J}=\right.$ $7.15 \mathrm{~Hz}, 6 \mathrm{H}, \mathrm{COOCH}_{2} \mathrm{CH}_{3}$ ), $1.61-1.67$ (m, $\left.2 \mathrm{H}, 12-\mathrm{H}\right), 1.80$ (m, $\left.2 \mathrm{H}, 13-\mathrm{H}\right), 2.36$ (t, ${ }^{3} J$ = $6.80 \mathrm{~Hz}, 2 \mathrm{H}, 4-\mathrm{H}), 2.57$ (m, 4 H, 11(14)-H), 2.68 (t, $\left.{ }^{3} \mathrm{~J}=6.58 \mathrm{~Hz}, 2 \mathrm{H}, 3-\mathrm{H}\right), 3.26$ (s, 2 H, 6-H), 4.20 (q, ${ }^{3} \mathrm{~J}=7 \mathrm{~Hz}, 4 \mathrm{H}, \mathrm{COOCH}_{2} \mathrm{CH}_{3}$ ), 6.86 (s, $\left.1 \mathrm{H}, 8-\mathrm{H}\right), 7.20-7.40$ (m, $5 \mathrm{H}$, Aromatic-H).- ${ }^{1} \mathrm{H}-\mathrm{NMR}\left(500 \mathrm{MHz}, \mathrm{CDCl}_{3}\right): \delta=1.21\left(\mathrm{t},{ }^{3} \mathrm{~J}=7.5 \mathrm{~Hz}, 6 \mathrm{H}\right.$, $\mathrm{COOCH}_{2} \mathrm{CH}_{3}$ ), 1.64 (m, 2 H, 12-H), 1.80 (m, 2 H, 13-H), 2.36 (t, ${ }^{3} J=7.5$ Hz, $\left.2 \mathrm{H}, 4-\mathrm{H}\right)$, 2.55 (t, $\left.{ }^{3} J=5 \mathrm{~Hz}, 2 \mathrm{H}, 14-\mathrm{H}\right), 2.60$ (t, $\left.{ }^{3} \mathrm{~J}=5.5 \mathrm{~Hz}, 2 \mathrm{H}, 11-\mathrm{H}\right), 2.68$ (t, ${ }^{3} \mathrm{~J}=6 \mathrm{~Hz}, 2 \mathrm{H}, 3-$ H), 3.26 (s, 2 H, 6-H), 4.18 (q, ${ }^{3} J=6$ Hz, 4 H, COOCH $\mathrm{CH}_{3}$ ), 686 (s, $\left.1 \mathrm{H}, 8-\mathrm{H}\right), 7.20$ - 
7.40 (m, $5 \mathrm{H}$, Aromatic-H) .- ${ }^{13} \mathrm{C}-\mathrm{NMR}\left(150.82 \mathrm{MHz}, \mathrm{CDCl}_{3}, \mathrm{APT}\right): \delta=14.01(+$, $\mathrm{COOCH}_{2} \mathrm{CH}_{3}$ ) , 22.82 (-, C-3), 23.00 (-, C-13*), 23.30 (-, C-12*), 26.82 (-, C-4), 28.19 $\left(-, \mathrm{C}-14^{* *}\right), 28.80$ (-, C-11**), 34.91 (-, C-6), 53.08 (- , C-5), 61.34 (-, $\mathrm{COOCH}_{2} \mathrm{CH}_{3}$ ), 126.49 (+, Aromatic-C) 127.50, (+, Aromatic-C), 127.86 (+, C-8), 128.00 (+, AromaticC), 129.26 (+, Aromatic-C), 132.06 (-, Aromatic-C), 132.58 (-, Aromatic-C), 135.14 (-, Aromatic-C), 139.89 (-, Aromatic-C), 142.06 (-, Aromatic-C), 171.38 (-, $\mathrm{COOCH}_{2} \mathrm{CH}_{3}$ ).- MS (DCI, $\mathrm{NH}_{3}, 70 \mathrm{eV}$ ) m/z (\%): 830 (4) [2M+NH$\left.{ }_{4}^{+}\right], 424$ (100) $\left[\mathrm{M}+\mathrm{NH}_{4}{ }^{+}\right], 352$ (4) $\left[\left(\mathrm{M}-\mathrm{COOCH}_{2} \mathrm{CH}_{3}\right)+\mathrm{NH}_{4}{ }^{+}\right] .-\mathrm{C}_{26} \mathrm{H}_{30} \mathrm{O}_{4}$ (406.5).

\section{8-(tert-butyldimethylsilyl)-tricyclo[8.4.0.0 $\left.0^{2,7}\right]$ tetradeca-1,7,9-triene (91)}<smiles>C[As](C)(C)c1cc2c(c3c1CCCC3)CCCC2</smiles>

By adapting GP8 method B, $11.8 \mathrm{mg}(0.052 \mathrm{mmol})$ of palladium acetate was added at $80{ }^{\circ} \mathrm{C}$ to a degassed mixture of $33 \mathrm{mg}(0.125$ mmol) of triphenylphosphine, $42 \mathrm{mg}(0.62 \mathrm{mmol})$ of sodium formate and $200 \mathrm{mg}(0.52 \mathrm{mmol})$ of 2-bromo-14-(tertbutyldimethylsilyl)-1-tetradecen-7,13,-diyne(79) in $5 \mathrm{ml}$ DMF. After stirring from $3 \mathrm{~h}$ at $80{ }^{\circ} \mathrm{C}$, the reaction mixture was poured into $30 \mathrm{ml}$ of water and extracted $(3 \times 20 \mathrm{ml})$ with diethyl ether. The combined ether layers were dried $\left(\mathrm{MgSO}_{4}\right)$, concentrated and the residue was eluted from a column of silica gel (7 g) with pentane to afford two fractions. The first fraction was composed of polymers. The second fraction afforded $30 \mathrm{mg}$ (20\%) of 91 as orange oil. $\left(\mathrm{R}_{\mathrm{f}}=0.80\right.$, pentane).-IR (Film): $v=3053 \mathrm{~cm}^{-1}$, 2957, 2926, 2854, 1667, 1571, 1469, 1391, 1252, 1075, 1008, 838, 775, 739, 676.- ${ }^{1} \mathrm{H}-$ NMR (250 MHz, CDCl $\left.)_{3}\right): \delta=0.31$ (s, 6 H, TBDMS-H), 0.90 (s, 9 H, TBDMS-H), 1.66 - 1.88 (m, 8 H, 4(5,12,13)-H), $2.53-2.60$ (m, 4 H, 3(11)-H), 2.73 (t, ${ }^{3} J=5.91$ Hz, 2 H, 6H), $2.81\left(\mathrm{t},{ }^{3} J=5.95 \mathrm{~Hz}, 2 \mathrm{H}, 14-\mathrm{H}\right), 7.04$ (s, $\left.1 \mathrm{H}, 9-\mathrm{H}\right) .-{ }^{1} \mathrm{H}-\mathrm{NMR}\left(500 \mathrm{MHz}, \mathrm{CDCl}_{3}\right)$ : $\delta=0.28(\mathrm{~s}, 6 \mathrm{H}, \mathrm{TBDMS}-\mathrm{H}), 0.88(\mathrm{~s}, 9 \mathrm{H}, \mathrm{TBDMS}-\mathrm{H}), 1.67-1.84(\mathrm{~m}, 8 \mathrm{H}$, 4(5,12,13)-H), $2.52-2.59$ (q, $\left.{ }^{3} J=5.5 \mathrm{~Hz}, 4 \mathrm{H}, 3(11)-\mathrm{H}\right), 2.72\left(\mathrm{t},{ }^{3} J=5.5 \mathrm{~Hz}, 2 \mathrm{H}, 6-\mathrm{H}\right)$, $2.80\left(\mathrm{t},{ }^{3} \mathrm{~J}=5.5 \mathrm{~Hz}, 2 \mathrm{H}, 14-\mathrm{H}\right), 7.05$ (s, $\left.1 \mathrm{H}, 9-\mathrm{H}\right) .-{ }^{13} \mathrm{C}-\mathrm{NMR}\left(125.705 \mathrm{MHz}, \mathrm{CDCl}_{3}\right): \delta$ $=-2.48$ (TBDMS-C), 18.03 (TBDMS-C), 22.84 (C- 12*), 23.08 (C-13*), $23.16\left(\mathrm{C}-4^{*}\right)$, 23.52 (C-5), $26.43\left(\mathrm{C}-11^{* *}\right), 26.73\left(\mathrm{C}-3^{* *}\right), 27.14$ (TBDMS-C), 30.14 (C-6), 32.21 (C- 
14), 132.92 (Aromatic-C), 133.13 (Aromatic-C) , 134.81 (Aromatic-C), 135.04 (C-9), 136.61 (Aromatic-C), 140.55 (Aromatic-C).- MS (EI, 70 eV), m/z (\%): 300 (8) [M+], 243 (100) $\left[\mathrm{M}^{+}-\mathrm{C}\left(\mathrm{CH}_{3}\right)_{3}\right] .-\mathrm{C}_{20} \mathrm{H}_{32} \mathrm{Si}$ (300.5): found 300.2273 (HRMS correct)

5-(tert-butyldimethylsilyloxy)-9-(tertbutyldimethylsilyl)tricyclo[8.4.0.0 2,7 $]$ tetradeca-1,7,9triene (92)<smiles>CCO[C@H]1CCc2c(cc([AsH2])c3c2CCCC3)C1</smiles>

By adapting GP8 method B, $8.8 \mathrm{mg}(0.039 \mathrm{mmol})$ of palladium acetate was added at $80{ }^{\circ} \mathrm{C}$ to a degassed mixture of $25.68 \mathrm{mg}$ (0.098 mmol) of triphenylphosphine, $53.2 \mathrm{mg}(0.78$ mmol) of sodium formate, $129.4 \mathrm{mg}(0.78 \mathrm{mmol})$ of tetraethylammonium chloride, and $200 \mathrm{mg}(0.39 \mathrm{mmol})$ of 2bromo-4-(tert-butyldimethylsilyloxy)-14-(tert-butyldimythylsilyl)-1-tetradecen-7,13diyne $(80)$ in $5 \mathrm{ml}$ DMF. After stirring from $4 \mathrm{~h}$ at $80{ }^{\circ} \mathrm{C}$, the reaction mixture was poured into $30 \mathrm{ml}$ of water and extracted $(3 \times 20 \mathrm{ml})$ with diethyl ether. The combined ether layers were dried $\left(\mathrm{MgSO}_{4}\right)$, concentrated and the residue was eluted from $20 \times 20 \mathrm{~cm}$ plates coated with thick layer of silica gel (Silica gel $60 \mathrm{PF}_{254}$ containing $\mathrm{CaSO}_{4}$ ) with 100:1 pentane/diethyl ether. The fourth fraction $\left(\mathrm{R}_{\mathrm{f}}=0.8\right.$, 80:1 pentane/ diethyl ether) from the plates' top afforded $28 \mathrm{mg}$ (16\%) of the title compound as a pale yellow solid. -IR $(\mathrm{KBr}): v=2855 \mathrm{~cm}^{-1}, 1468,1292,1092,837,774,685 .-{ }^{1} \mathrm{H}-\mathrm{NMR}\left(250 \mathrm{MHz}, \mathrm{CDCl}_{3}\right): \delta$ $=0.10(\mathrm{~s}, 6 \mathrm{H}, \mathrm{O}-\mathrm{TBDMS}-\mathrm{H}), 0.32$ (s, 6 H, C- TBDMS-H), 0.91 (s, 9 H, C-TBDMSH), 0.92 (s, 9 H, O -TBDMS-H), 1.68 - 1.87 (m, 5 H, 4(12,13)-H), 2.03 (m, 1 H, 4 H), 2.50 - 2.63 (m, 4 H, 3(11)-H), 2.70 - 2.95 (m, 4 H, 6(14)-H), 4.03 (m, 1 H, 5-H), 7.03 (s, $1 \mathrm{H}, 8-\mathrm{H}$ ). $-{ }^{13} \mathrm{C}-\mathrm{NMR}$ ( $125.705 \mathrm{MHz}, \mathrm{CDCl}_{3}$ ): $\delta=-4.59$ (O -TBDMS-C), - 4.56 (O TBDMS-C ), - 2.56 (C-TBDMS-C), -2.42 (C-TBDMS-C), 18.03 (C-TBDMS-C), 18.27 (O -TBDMS-C), 23.05 (C- 13*), 23.13 (C-12* ), 25.71 (C-3**), 25.95 (O -TBDMS-C), 26.92 (C-11**), 27.13 (C- TBDMS-C), 32.16 (C-14), 32.65 (C-4), 39.81 (C-6), 68.24 (C5), 131.33(Aromatic- C), 133.60 (Aromatic-C), 134.43 (Aromatic-C), 135.18 (C-8), 135.49 (Aromatic-C), 140.95 (Aromatic-C).- MS (DCI, NH 3,70 eV) m/z (\%): 878 (0.1) $\left[2 \mathrm{M}+\mathrm{NH}_{4}^{+}\right], 449(32)\left[(\mathrm{M}+\mathrm{H})+\mathrm{NH}_{4}^{+}\right], 448(94)\left[\mathrm{M}+\mathrm{NH}_{4}{ }^{+}\right], 431(100)\left[\mathrm{M}+\mathrm{H}^{+}\right], 390(17)$ 
$\left[(\mathrm{M}+\mathrm{H})-\mathrm{C}\left(\mathrm{CH}_{3}\right)_{3}+\mathrm{NH}_{4}{ }^{+}\right], 334$ (16) $\left[\left(\mathrm{M}-\mathrm{t}-\mathrm{BuMe}_{2} \mathrm{Si}\right)+\mathrm{NH}_{4}{ }^{+}\right], 299$ (17), 185 (10), 132 (4). $-\mathrm{C}_{26} \mathrm{H}_{46} \mathrm{OSi}_{2}(430.8)$.

Methyl 13-(tert-butyldimethylsilyloxy)tetracyclo[8.4.0.0 $\left.0^{1,3} \cdot 0^{4,9}\right]$ tetradeca-4,9-dien-3carboxylate (122)

By adapting GP8 method A, $9.8 \mathrm{mg}(0.050 \mathrm{mmol})$ of palladium acetate was added at 60 ${ }^{\circ} \mathrm{C}$ to a degassed mixture, placed in a Pyrex ${ }^{\circledR}$ crucible, of $29 \mathrm{mg}(0.11 \mathrm{mmol})$ of

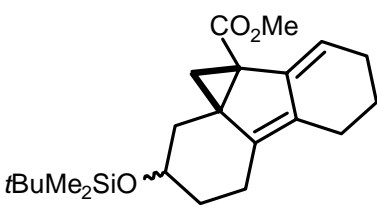
triphenylphosphine, $182.6 \mathrm{mg}(1.3 \mathrm{mmol})$ of potassium carbonate, and $200 \mathrm{mg}$ (0.44 mmol) of Methyl-14-bromo- 12(tert-butyldimethylsilyloxy)-14-pentadecene-2,8-diynoate in $5 \mathrm{ml}$ acetonitrile. The reaction mixture was stirred at $60{ }^{\circ} \mathrm{C}$ for $18 \mathrm{~h}$ and worked up as described in GP8 method A. The residue was purified by thick layer chromatography using $20 \times 20 \mathrm{~cm}$ plates coated with thick layer of silica gel (Silica gel $60 \mathrm{PF}_{254}$ containing $\mathrm{CaSO}_{4}$ ). The plates were developed twice, once by using 2:1 pentane/dichloromethane and another by 10:1 pentane/diethyl ether. The first fraction $\left(\mathrm{R}_{\mathrm{f}}\right.$ $=0.12,5: 1$ pentane/diethyl ether) from the plates' top afforded $32 \mathrm{mg}(19 \%)$ of 2:1 of a diasteromeric mixture of the title compound as a colorless oil .-IR (Film): $v=2957$ $\mathrm{cm}^{-} 1$, 2854, 2240, 1734, 1437, 1255, 1202, 835, 777, 736.- ${ }^{1} \mathrm{H}-\mathrm{NMR}$ ( $250 \mathrm{MHz}, \mathrm{CDCl}_{3}$ ): $\delta=0.064$ (s, 6 H, TBDMS-H), 0.90 (s, 9 H, TBDMS- H), 1.05 (d, ${ }^{2} J=3.20 \mathrm{~Hz}, 1 \mathrm{H}$, 2-H), 1.42 (m, 1 H, 4-H), 1.64 - 1.74 (m, 2 H, 7(8)-H), 1.82 (m, 3 H, 12(14)-H), 1.90 (d, $\left.{ }^{2} J=3.11 \mathrm{~Hz}, 1 \mathrm{H}, 2-\mathrm{H}\right), 2.02-2.18$ (m, 2 H, 6(8)-H), 2.23 - 2.34 (m, 3 H, 6(7,11)-H ), $2.51\left(\mathrm{~d},{ }^{3} \mathrm{~J}=5.6 \mathrm{~Hz}, 11-\mathrm{H}\right), 3.71\left(\mathrm{~s}, 3 \mathrm{H}, \mathrm{COOCH}_{3}\right), 4.25$ (s, $\left.1 \mathrm{H}, 13-\mathrm{H}\right), 5.89\left(\mathrm{t},{ }^{3} J=4.3\right.$ $\mathrm{Hz}, 1 \mathrm{H}, 5-\mathrm{H}) .-{ }^{1} \mathrm{H}-\mathrm{NMR}\left(500 \mathrm{MHz}, \mathrm{CDCl}_{3}\right): \delta=0.04$ (s, $6 \mathrm{H}$, TBDMS-H), 0.88 (s, $9 \mathrm{H}$, TBDMS-H ), 1.03 (d, ${ }^{2} J=3.1$ Hz, 1 H, 2-H), 1.40 (m, 1 H, 14-H), 1.54 - 1.72 (m, 1 H, 7H), 1.74 (t, $\left.{ }^{3} J=4 \mathrm{~Hz}, 1 \mathrm{H}, 8-\mathrm{H}\right), 1.80$ (m, $\left.3 \mathrm{H}, 10(14)-\mathrm{H}\right), 1.90$ (d, ${ }^{2} \mathrm{~J}=3.15 \mathrm{~Hz}, 1 \mathrm{H}, 2-$ H), 2.00 (m, 1 H, 8-H), 2.10 (m, 1 H, 6-H), $2.20-2.34$ (m, 3 H, 6(7,11)-H), 2.50 (d, ${ }^{3} J=$ $5 \mathrm{~Hz}, 1 \mathrm{H}, 11-\mathrm{H}$ ), 3.70 (s, $3 \mathrm{H}, \mathrm{COOCH}_{3}$ ), 4.24 (bs, $\left.1 \mathrm{H}, 13-\mathrm{H}\right), 5.88$ (t, ${ }^{3} \mathrm{~J}=5.5 \mathrm{~Hz}, 1 \mathrm{H}$ ,5-H).- ${ }^{13} \mathrm{C}-\mathrm{NMR}\left(125.705 \mathrm{MHz}, \mathrm{CDCl}_{3}, \mathrm{APT}\right): \delta=-4.88$ (+, TBDMS-C), 17.99 (-, TBDMS-C), 19.10 (-, C-11), 22.46 (-, C-7), 22.65 (-, C-8), 25.43 (-, C-6), 25.75 (+, TBDMS-C), 31.68 (-, C-14), 34.82 (-, C-12), 35.53 (-, C-3), 38.77 (-, C-2), 43.37 (-, 
C-1), 51.63 (+, $\mathrm{COOCH}_{3}$ ), 66.77 (+, C-13), 120.52 (+, C-5), 128.21 (-, C-9), 139.45 (-, C-10), 142.12 (-, C-4), 171.92 (-, $\mathrm{COOCH}_{3}$ ).- MS (DCI, $\left.\mathrm{NH}_{3}, 70 \mathrm{eV}\right) \mathrm{m} / \mathrm{z}(\%): 392$ (100) $\left[\mathrm{M}+\mathrm{NH}_{4}^{+}\right], 375(70)\left[\mathrm{M}+\mathrm{H}^{+}\right], 260$ (8) $\left[\mathrm{M}^{+}-\mathrm{t}-\mathrm{BuMe}{ }_{2} \mathrm{Si}\right] .-\mathrm{C}_{22} \mathrm{H}_{34} \mathrm{O}_{3} \mathrm{Si}$ (374.6) calcd for: C 70.54, H 9.15; found: C 70.42, H 9.03

6,6-dimethyl 3-methyl tetracyclo[8.4.0.0 $\left.0^{1,3} \cdot 0^{4,9}\right]$ tetradeca-4,9-diene-3,6,6-tricarboxylate (119-COOMe) $(\mathrm{E}=\mathrm{COOMe})$

By adapting GP8 method A, $150 \mathrm{mg}(0.66 \mathrm{mmol})$ of palladium acetate was added at 60 ${ }^{\circ} \mathrm{C}$ to a degassed mixture, placed in a Pyrex ${ }^{\circledR}$ crucible, of $430 \mathrm{mg}$ (1.64 mmol) of

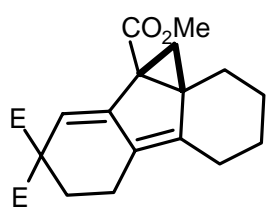
triphenylphosphine , $2.72 \mathrm{~g}(19.7 \mathrm{mmol})$ of potassium carbonate, and $2.9 \mathrm{~g}(6.59 \mathrm{mmol})$ of 11,11-dimethyl-1-methyl 13-bromo-13tetradecen-1,7-diyne-1,11,11-tricarboxylate in 100ml acetonitrile. After stirring at $60{ }^{\circ} \mathrm{C}$ for $20 \mathrm{~h}$, the reaction mixture was cooled and filtered over two layers of Celite ${ }^{\circledR}$ and silica gel. The resulting filtrate was treated with $200 \mathrm{ml}$ of water and extracted with $(4 \times 50 \mathrm{ml})$ of diethyl ether. The combined organic phases were dried $\left(\mathrm{MgSO}_{4}\right)$, concentrated, and the residue was purified by column chromatography (60 g silica gel and 4:1 pentane/diethyl ether) to afford $1.3 \mathrm{~g}$ (54\%) of an orange oil. $\left(\mathrm{R}_{\mathrm{f}}=0.17,4: 1\right.$ pentane/diethyl ether).-IR (Film): $v=2996 \mathrm{~cm}^{-1} 1,2954,2855$, 1755, 1715, 1433, 1302, 1226, 1197, 1154, 1076, 1062, 851, 833, 735, 702.- ${ }^{1} \mathrm{H}-\mathrm{NMR}$ (250 MHz, $\left.\mathrm{CDCl}_{3}\right): \delta=1.07\left(\mathrm{~d},{ }^{2} J=2.9 \mathrm{~Hz}, 1 \mathrm{H}, 2-\mathrm{H}\right), 1.24$ (m, $\left.1 \mathrm{H}, 12-\mathrm{H}\right), 1.46-1.56$ (m, $1 \mathrm{H}, 12-\mathrm{H}), 2.68$ (dt, $\left.{ }^{2} J=2.8 \mathrm{~Hz},{ }^{3} J=15 \mathrm{~Hz}, 1 \mathrm{H}, 14-\mathrm{H}\right), 1.8$ - 1.89 (m, $2 \mathrm{H}, 11(14)-$ H), 1.95 (d, $\left.{ }^{2} J=3.0 \mathrm{~Hz}, 1 \mathrm{H}, 2-\mathrm{H}\right), 2.00-2.37$ (m, 4 H, 7 (8,13)-H ), 2.40 - 2.61 (m, 3 H, 8(11,13)-H), 3.70 (s, $3 \mathrm{H}, \mathrm{COOCH}_{3}$ ), 3.72 (s, $3 \mathrm{H}, \mathrm{COOCH}_{3}$ ), 3.75 (s, $3 \mathrm{H}, \mathrm{COOCH}_{3}$ ), 6.09 (s, $1 \mathrm{H}, 5-\mathrm{H}) \cdot{ }^{-13} \mathrm{C}-\mathrm{NMR}$ ( $\left.62.5 \mathrm{MHz}, \mathrm{CDCl}_{3}, \mathrm{DEPT}\right): \delta=19.15$ (-, C-8), 24.82 (-, C-12), 24.93 (-, C-11), 25.36 (-, C-13), 27.98 (-, C-14), 28.70 (-, C-7), 36.65 (C quart, C-3), 39.29 (-, C-2), 45.88 ( $\left.\mathrm{C}_{\text {quart }}, \mathrm{C}-1\right), 51.80$ (+, $\left.\mathrm{COOCH}_{3}\right), 52.68$ (+, $\left.\mathrm{COOCH}_{3}\right), 52.82$ (+, $\left.\mathrm{COOCH}_{3}\right), 55.28$ (C $\left.\mathrm{C}_{\text {quart }}, \mathrm{C}-6\right), 115.88$ (+, C-5), 126.03 (C $\left.\mathrm{C}_{\text {quart }}, \mathrm{C}-9\right), 143.53$ (C $\mathrm{C}_{\text {quat }}, \mathrm{C}-$ 4), 144.75 ( $\left.\mathrm{C}_{\text {quart, }} \mathrm{C}-10\right), 170.96\left(\mathrm{C}_{\text {quart }}, \mathrm{COOCH}_{3}\right), 171.35\left(\mathrm{C}_{\text {quart }}, \mathrm{COOCH}_{3}\right), 171.72$ $\left(\mathrm{C}_{\text {quart, }} \mathrm{COOCH}_{3}\right) . .-\mathrm{MS}(\mathrm{EI}, 70 \mathrm{eV}), \mathrm{m} / \mathrm{z}(\%)$ : $360(10)\left[\mathrm{M}^{+}\right], 328(24)\left[\mathrm{M}^{+}-\mathrm{CH}_{3} \mathrm{OH}\right]$, 
301 (30) [ $\left.\mathrm{M}^{+}-\mathrm{COOCH}_{3}\right], 269$ (46) [ $\left.\mathrm{M}^{+}-\mathrm{CH}_{3} \mathrm{OH}-\mathrm{COOCH}_{3}\right], 241$ (39), 209 (20), 159 (30), 115 (72), 74 (79), 59 (100), 45 (64), 43 (27).- $\mathrm{C}_{20} \mathrm{H}_{24} \mathrm{O}_{6}(360.4)$ calcd for: C 66.65, H 6.43; found: C 66.76, H 6.43.

6,6-diethyl 3-methyl tetracyclo[8.4.0.0 $\left.0^{1,3} \cdot 0^{4,9}\right]$ tetradeca-4,9-diene-3,6,6-tricarboxylate (119-COOEt) $(\mathrm{E}=\mathrm{COOEt})$

Similar procedure for preparing the dimethyl derivetive was followed. However, the compound was purified by thick layer chromatography $20 \times 20 \mathrm{~cm}$ plates coated with thick layer of silica gel (Silica gel $60 \mathrm{PF}_{254}$ containing $\mathrm{CaSO}_{4}$ ). After elution with 4:1 pentane/diethyl ether, the first fraction $\left(R_{f}=0.43\right.$, 4:1 pentane/diethyl ether), from the plates' top, offered the title compound in a 52\% yield as an orange oil.-IR (Film): $v=$ $2932 \mathrm{~cm}^{-1}, 1732,1438,1235,1063 .-{ }^{1} \mathrm{H}-\mathrm{NMR}\left(250 \mathrm{MHz}, \mathrm{CDCl}_{3}\right): \delta=1.07\left(\mathrm{~d},{ }^{2} \mathrm{~J}=3.0\right.$ Hz, 1 H, 2-H), 1.16 - 1.41 (m, 7 H, 12-H, $\mathrm{COOCH}_{2} \mathrm{CH}_{3}$ ), 1.46 - 1.65 (m, 2 H, 12(14)-H), 1.79 - 1.89 (m, 2 H, 11(14)-H), 1.94 (d, $\left.{ }^{2} J=3.0 \mathrm{~Hz}, 1 \mathrm{H}, 2-\mathrm{H}\right), 1.99$ - 2.38 (m, $4 \mathrm{H}$, 7(8,13)-H), 2.40 - 2.54 (m, 3H, 8(11,13)-H), 3.72 (s, 3 H, COOCH $), 4.13$ - 4.25 (m, 4 H, $\mathrm{COOCH}_{2} \mathrm{CH}_{3}$ ), 6.03 (s, $\left.1 \mathrm{H}, 5-\mathrm{H}\right) .{ }^{1} \mathrm{H}-\mathrm{NMR}\left(500 \mathrm{MHz}, \mathrm{CDCl}_{3}\right): \delta=1.04$ (d, ${ }^{2} J=3.0 \mathrm{~Hz}$, $1 \mathrm{H}, 2-\mathrm{H}), 1.14-1.30$ (m, $\left.7 \mathrm{H}, 12-\mathrm{H}, \mathrm{COOCH}_{2} \mathrm{CH}_{3}\right), 1.46$ (m, $\left.1 \mathrm{H}, 12-\mathrm{H}\right), 1.62\left(\mathrm{dt},{ }^{2} \mathrm{~J}=\right.$ $\left.{ }^{3} \mathrm{Jax}-\mathrm{ax}=10 \mathrm{~Hz},{ }^{3} \mathrm{Jax}-\mathrm{eq}=3 \mathrm{~Hz}, 1 \mathrm{H}, 14-\mathrm{H}\right), 1.78$ (m, $\left.1 \mathrm{H}, 14-\mathrm{H}\right), 1.83$ (m, $\left.1 \mathrm{H}, 11-\mathrm{H}\right)$, $1.92\left(\mathrm{~d},{ }^{2} \mathrm{~J}=3 \mathrm{~Hz}, 1 \mathrm{H}, 2-\mathrm{H}\right), 1.96$ (m, 1 H, 13-H), 2.00- 2.08 (m, 1 H, 7-H), 2.22 - 2.28 (m, 1 H, 8-H), 2.38 - 2.54 (m, 3 H, 8(11,13)-H), 3.70 (s, 3 H, $\mathrm{COOCH}_{3}$ ), 4.08 - 4.22 (m, 4 $\mathrm{H}, \mathrm{COOCH}_{2} \mathrm{CH}_{3}$ ), 6.02 (s, $\left.1 \mathrm{H}, 5-\mathrm{H}\right) \cdot-{ }^{13} \mathrm{C}-\mathrm{NMR}\left(62.5 \mathrm{MHz}, \mathrm{CDCl}_{3}, \mathrm{DEPT}\right): \delta=14.04$ (+, $\mathrm{COOCH}_{2} \mathrm{CH}_{3}$ ), 19.14 (-, C-8), 24.84 (-, C-12), 24.93 (- , C-11), 25.36 (-, C-13),

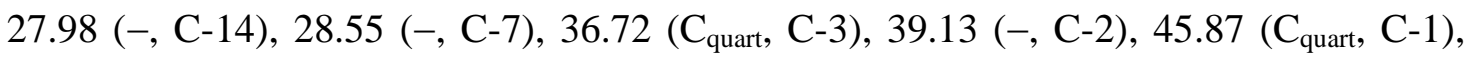
51.77 (+, $\left.\mathrm{COOCH}_{3}\right), 55.28$ ( $\left.\mathrm{C}_{\text {quart }}, \mathrm{C}-6\right), 65.83$ (-, $\left.\mathrm{COOCH}_{2} \mathrm{CH}_{3}\right), 116.22(+, \mathrm{C}-5), 126.21$ (C $\left.\mathrm{C}_{\text {quart, }} \mathrm{C}-9\right), 143.23$ ( $\left.\mathrm{C}_{\text {quart }}, \mathrm{C}-4\right), 144.58$ (C quart, C-10), $170.92\left(\mathrm{C}_{\text {quart }}, \mathrm{COOCH}_{2} \mathrm{CH}_{3}\right)$, $170.97\left(\mathrm{C}_{\text {quart }}, \mathrm{COOCH}_{2} \mathrm{CH}_{3}\right), 171.17\left(\mathrm{C}_{\text {quart }}, \mathrm{COOCH}_{3}\right)$.- MS ( EI, $70 \mathrm{eV}$ ), m/z (\%): 388 (78) $\left[\mathrm{M}^{+}\right], 357$ (30) $\left[\mathrm{M}^{+}-\mathrm{OCH}_{3}\right], 356$ (100) $\left[\mathrm{M}^{+}-\mathrm{CH}_{3} \mathrm{OH}\right], 329$ (68) $\left[\mathrm{M}^{+}-\mathrm{COOCH}_{3}\right], 315$ (24) $\left[\mathrm{M}^{+}-\mathrm{COOCH}_{2} \mathrm{CH}_{3}\right], 314$ (34), 283 (97) $\left[\mathrm{M}^{+}-\mathrm{CH}_{3} \mathrm{OH}-\mathrm{COOCH}_{2} \mathrm{CH}_{3}\right], 255$ (60) $\left[\mathrm{M}^{+}-\mathrm{COOCH}_{2} \mathrm{CH}_{3}-\mathrm{COOCH}_{2} \mathrm{CH}_{3}\right], 211$ (34) , 183 (38) , 155 (12) , 141 (21).- $\mathrm{C}_{22} \mathrm{H}_{28} \mathrm{O}_{6}$ (388.4): found 388.1885 (HRMS correct) 
Palladium catalysed oligocyclization of Methyl 11-(2'-bromoallyloxy)-2,8undecadiynoate (132)

By adapting GP8 method A, $34 \mathrm{mg}(0.15 \mathrm{mmol})$ of palladium acetate was added to a mixture, placed in a Pyrex ${ }^{\circledR}$ crucible, of $99.8 \mathrm{mg}(0.38 \mathrm{mmol})$ of triphenylphosphine 630 $\mathrm{mg}(4.5 \mathrm{mmol})$ of potassium carbonate, and $500 \mathrm{mg}(1.5 \mathrm{mmol})$ of methyl 11-(2'bromoallyloxy)-2,8-undecadiynoate (132) in $30 \mathrm{ml}$ acetonitrile. The reaction mixture was stirred at $106{ }^{\circ} \mathrm{C}$ for $18 \mathrm{~h}$ and worked up as described in GP8 method A. The residue was purified by thick layer chromatography using $20 \times 20 \mathrm{~cm}$ plates coated with thick layer of silica gel (Silica gel $60 \mathrm{PF}_{254}$ containing $\mathrm{CaSO}_{4}$ ). The plates were eluted twice with 5:1 pentane/dichloromethane and once with 10:1 pentane/diethyl ether to afford the following fractions:

\section{Fraction I}

Methyl 1,4,7,8,9,10-hexahydro-2H-benzo[f]isochromene-6-carboxylate (135)

The first fraction $\left(\mathrm{R}_{\mathrm{f}}=0.23\right.$, 5:1 pentane/diethyl ether) from the plates' top afforded 35 mg (10\%) of the title compound as a white solid .-IR (KBr): $v=2938$<smiles>CC(=O)c1cc2c(c3c1CCCC3)CCOC2</smiles>
$\mathrm{cm}^{-1}, 1719,1430,1292,1202,1184,1155,1017,925,778 .-{ }^{1} \mathrm{H}-\mathrm{NMR}$ $\left(250 \mathrm{MHz}, \mathrm{CDCl}_{3}\right): \delta=1.71-1.83(\mathrm{~m}, 4 \mathrm{H}, 8(9)-\mathrm{H}), 2.59\left(\mathrm{t},{ }^{3} \mathrm{~J}=6 \mathrm{~Hz}\right.$, $2 \mathrm{H}, 10-\mathrm{H}), 2.66\left(\mathrm{t},{ }^{3} \mathrm{~J}=5.7 \mathrm{~Hz}, 2 \mathrm{H}, 1-\mathrm{H}\right), 3.03\left(\mathrm{t},{ }^{3} \mathrm{~J}=5.9 \mathrm{~Hz}, 2 \mathrm{H}, 7-\right.$ H), 3.85 (s, 3H, $\mathrm{COOCH}_{3}$ ), 3.99 (t, $\left.{ }^{3} \mathrm{~J}=5.8 \mathrm{~Hz}, 2 \mathrm{H}, 2-\mathrm{H}\right), 4.74$ (s, $2 \mathrm{H}$, 4-H), 7.35 (s, $1 \mathrm{H}, 5-\mathrm{H}) .-{ }^{1} \mathrm{H}-\mathrm{NMR}\left(500 \mathrm{MHz}, \mathrm{CDCl}_{3}\right): \delta=1.68$ - 1.77 (m, $\left.2 \mathrm{H}, 8-\mathrm{H}\right)$, 1.78 - 1.84 (m, 2H, 9-H), 2.57 (t, $\left.{ }^{3} J=5.5 \mathrm{~Hz}, 2 \mathrm{H}, 10-\mathrm{H}\right), 2.64$ (t, $\left.{ }^{3} J=5.6 \mathrm{~Hz}, 2 \mathrm{H}, 1-\mathrm{H}\right)$, $3.01\left(\mathrm{t},{ }^{3} \mathrm{~J}=6 \mathrm{~Hz}, 2 \mathrm{H}, 7-\mathrm{H}\right), 3.82$ (s, $\left.3 \mathrm{H}, \mathrm{COOCH}_{3}\right), 4.00$ (t, $\left.{ }^{3} \mathrm{~J}=6.1 \mathrm{~Hz}, 2 \mathrm{H}, 2-\mathrm{H}\right), 4.71$ (s, 2H, 4-H), 7.34 (s, $1 \mathrm{H}, 5-\mathrm{H}) .-{ }^{13} \mathrm{C}-\mathrm{NMR}\left(62.5 \mathrm{MHz}, \mathrm{CDCl}_{3}, \mathrm{DEPT}\right): \delta=22.37$ (-, C9), 22.61 (-, C-8), 26.08 (-, C-1), 26.55 (-, C-10), 28.19 (-, C-7), 51.77 (+, $\mathrm{COOCH}_{3}$ ), 65.21 (-, C-2), 67.97 (-, C-4), 123.86 (+, C-5), 127.77 ( $\mathrm{C}_{\text {quart, }}$ Aromatic-C), 131.59 ( $\mathrm{C}_{\text {quart, }}$ Aromatic-C), 136.00 ( $\mathrm{C}_{\text {quart }}$, Aromatic-C), 136.50 ( $\mathrm{C}_{\text {quart }}$, Aromatic-C), 136.60 ( $\mathrm{C}_{\text {quart }}$, Aromatic-C), $168.42\left(\mathrm{C}_{\text {quart }}, \mathrm{COOCH}_{3}\right)$.- MS (EI, $\left.70 \mathrm{eV}\right), \mathrm{m} / \mathrm{z}(\%): 246$ (100)

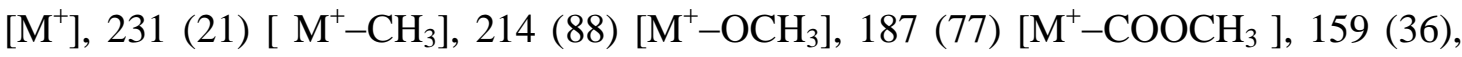
157 (19) $\left[\mathrm{M}^{+}-\mathrm{COOCH}_{3}-\mathrm{H}_{2} \mathrm{C}=\mathrm{O}\right], 141$ (17), 129 (25), 115 (23), 91 (16).- $\mathrm{C}_{15} \mathrm{H}_{18} \mathrm{O}_{3}$ 
(246.3): found 246.1256 (HRMS correct)

\section{Fraction II}

Methyl 1,5,5a,7,8,9-hexahydro-2H-cyclopropa[2,3]indeno[2,1-c]pyran-5a-carboxylate (134)

The second fraction $\left(\mathrm{R}_{\mathrm{f}}=0.18\right.$, 5:1 pentane/diethyl ether) from the plates' top afforded $80 \mathrm{mg}$ (21\%)of the title compound as a colorless oil .- IR (Film): $v=2992 \mathrm{~cm}^{-1} 1,2926$,

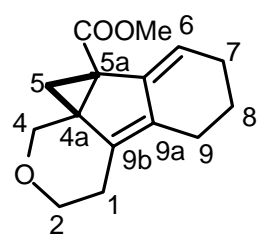
2857, 2827, 1715, 1436, 1382, 1363, 1298, 1247, 1221, 1199, 1163, 1082, 1050, 971, 855, 731, 666,611.- ${ }^{1} \mathrm{H}-\mathrm{NMR}\left(250 \mathrm{MHz}, \mathrm{CDCl}_{3}\right): \delta=$ $1.10\left(\mathrm{~d},{ }^{2} J=3.2 \mathrm{~Hz}, 1 \mathrm{H}, 5-\mathrm{H}\right), 1.65$ (m, 2 H, 8- H), 2.04 (d, ${ }^{2} J=2.08$ Hz, 1 H, 5-H), 2.07 - 2.39 (m, 6 H, 1(7,9)-H), 3.23 - 3.34 (m, 1 H, 2H), 3.69 (s, $3 \mathrm{H}, \mathrm{COOCH}_{3}$ ), 3.75 (d, $\left.{ }^{2} J=11.4 \mathrm{~Hz}, 1 \mathrm{H}, 4-\mathrm{H}\right), 4.0\left(\mathrm{~d},{ }^{2} J=11.4 \mathrm{~Hz}, 1 \mathrm{H}, 4-\right.$ H), 4.10 (dd, $\left.{ }^{2} \mathrm{~J}=9.4 \mathrm{~Hz},{ }^{3} \mathrm{~J}=4.2 \mathrm{~Hz}, 1 \mathrm{H}, 2-\mathrm{H}\right), 6.04\left(\mathrm{t},{ }^{3} \mathrm{~J}=4.2 \mathrm{~Hz}, 1 \mathrm{H}, 6-\mathrm{H}\right) .{ }^{1} \mathrm{H}-$ NMR (600 MHz, $\left.\mathrm{CDCl}_{3}\right): \delta=1.08$ (d, $\left.{ }^{2} J=3.1 \mathrm{~Hz}, 1 \mathrm{H}, 5-\mathrm{H}\right), 1.63$ (m, $\left.2 \mathrm{H}, 8-\mathrm{H}\right), 2.02$ (d, ${ }^{2} J=3$ Hz, 5-H), 2.05 - 2.15 (m, 2 H, 7(9)-H), 2.23 (m, 1 H, 7-H), 2.30 (m, 1 H, 9-H), $2.37\left(\mathrm{dt},{ }^{3} \mathrm{Jax}-\mathrm{ax}={ }^{2} \mathrm{~J}=10 \mathrm{~Hz},{ }^{3} \mathrm{Jax}-\mathrm{eq}=5 \mathrm{~Hz}, 1 \mathrm{H}, 2-\mathrm{H}\right), 3.67$ (s, $\left.3 \mathrm{H}, \mathrm{COOCH}_{3}\right), 3.74$ (d, ${ }^{2} J=12 \mathrm{~Hz}, 1 \mathrm{H}, 4-\mathrm{H}$ ), 3.99 (d, ${ }^{2} J=12 \mathrm{~Hz}, 1 \mathrm{H}, 4-\mathrm{H}$ ), 4.10 (ddd, ${ }^{2} J=11 \mathrm{~Hz},{ }^{3} \mathrm{Jeq}-\mathrm{eq}$ $\left.=5.5 \mathrm{~Hz},{ }^{3} \mathrm{Jeq}-\mathrm{ax}=2 \mathrm{~Hz}, 1 \mathrm{H}, 2-\mathrm{H}\right), 6.0\left(\mathrm{t},{ }^{3} \mathrm{~J}=4 \mathrm{~Hz}, 1 \mathrm{H}, 6-\mathrm{H}\right) \cdot-{ }^{13} \mathrm{C}-\mathrm{NMR}(150.82 \mathrm{MHz}$, $\left.\mathrm{CDCl}_{3}, \mathrm{DEPT}\right): \delta=22.19$ (-, C-8), 22.52 (-, C-9), 25.34 (-, C-7), 26.23 (-, C-1), 35.52

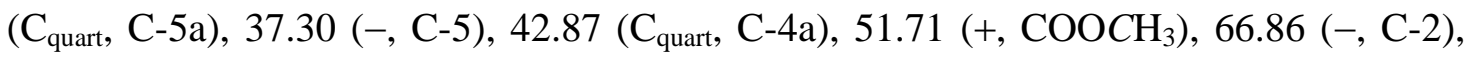
70.03 (-, C-4), 121.78 (+, C-6), 130.30 (C quart $_{1}$ C-9a), 134.77 (C quart, C-9b), 141.08 (C quart, C-5b), 171.30 ( $\left.\mathrm{C}_{\text {quart, }} \mathrm{COOCH}_{3}\right)$.- MS (EI, $\left.70 \mathrm{eV}\right), \mathrm{m} / \mathrm{z}(\%): 246$ (23) [M+1, 215 (6) $\left[\mathrm{M}^{+}-\mathrm{OCH}_{3}\right], 187$ (100) $\left[\mathrm{M}^{+}-\mathrm{COOCH}_{3}\right], 157$ (43) $\left[\mathrm{M}^{+}-\mathrm{COOCH}_{3}-\mathrm{H}_{2} \mathrm{C}=\mathrm{O}\right], 141$ (14), 129 (25), 115 (12).- $\mathrm{C}_{15} \mathrm{H}_{18} \mathrm{O}_{3}$ (246.3): found 246.1256 (HRMS correct) 


\section{Fraction IV}

\section{Methyl 1,4,5,6-tetrahydro-2H-benzo[f] isochromene-6-carboxylate (136)}

The fourth fraction $\left(\mathrm{R}_{\mathrm{f}}=0.11,5: 1\right.$ pentane/diethyl ether $)$ from the plates' top afforded 10 mg (3\%) of the title compound as a colorless oil.-IR (Film): $v=3029 \mathrm{~cm}^{-1}, 2954,2926$,

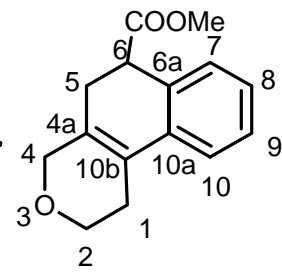

2252, 1740, 1490, 1435, 1270, 1214, 1158, 910, 765, 732.- ${ }^{1} \mathrm{H}-\mathrm{NMR}$ 1(5)-H), 3.66 (s, $\left.3 \mathrm{H}, \mathrm{COOCH}_{3}\right), 3.77$ (t, $\left.{ }^{3} \mathrm{~J}=5.2 \mathrm{~Hz}, 1 \mathrm{H}, 6-\mathrm{H}\right), 3.83$ - 3.98 (m, 1 H, 2-H), 4.00 - 4.08 (m, 1 H, 2-H), 4.14 (d, ${ }^{2} J=15$ Hz, 1 H, 4-H), 4.25 (d, $\left.{ }^{2} J=16 \mathrm{~Hz}, 1 \mathrm{H}, 4-\mathrm{H}\right), 7.16-7.31$ (m, $4 \mathrm{H}$, Aromatic-H).- ${ }^{1} \mathrm{H}-\mathrm{NMR}\left(500 \mathrm{MHz}, \mathrm{CDCl}_{3}\right): \delta=2.26$ (m, $\left.1 \mathrm{H}, 5-\mathrm{H}\right), 2.32$ (ddd, ${ }^{2} J=2 \mathrm{~Hz}$, $\left.{ }^{3} \mathrm{Jax}-\mathrm{eq}=3.5 \mathrm{~Hz},{ }^{3} \mathrm{Jax}-\mathrm{ax}=7 \mathrm{~Hz}, 1 \mathrm{H}, 1-\mathrm{H}\right), 2.43\left(\mathrm{dt},{ }^{2} \mathrm{~J}={ }^{3} \mathrm{Jeq}-\mathrm{ax}=1 \mathrm{~Hz},{ }^{3} \mathrm{Jeq}-\mathrm{eq}=4.5\right.$

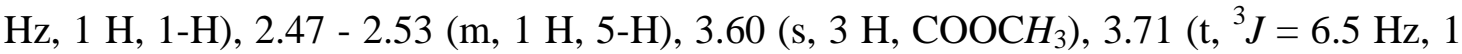
H, 6-H), 3.81 (ddd, $\left.{ }^{2} J=11 \mathrm{~Hz},{ }^{3} \mathrm{Jax}-\mathrm{ax}=7 \mathrm{~Hz},{ }^{3} \mathrm{Jax}-\mathrm{eq}=4.5 \mathrm{~Hz}, 1 \mathrm{H}, 2-\mathrm{H}\right), 3.95$ (dt, ${ }^{2} J$ $\left.=11.5 \mathrm{~Hz},{ }^{3} \mathrm{Jeq}-\mathrm{eq}={ }^{3} \mathrm{Jeq}-\mathrm{ax}=6 \mathrm{~Hz}, 1 \mathrm{H}, 2-\mathrm{H}\right), 4.08$ (d, $\left.{ }^{2} J=17 \mathrm{~Hz}, 1 \mathrm{H}, 4-\mathrm{H}\right), 4.17$ (d, ${ }^{2} J$ $=17 \mathrm{~Hz}, 4-\mathrm{H}), 7.08-7.22$ (m, $4 \mathrm{H}$, Aromatic-H). $-{ }^{13} \mathrm{C}-\mathrm{NMR}\left(62.5 \mathrm{MHz}, \mathrm{CDCl}_{3}\right.$, DEPT): $\delta=24.52$ (-, C-5), 26.49 (-, C- 1), 43.34 (+, C-6), 52.21 (+, $\left.\mathrm{COOCH}_{3}\right), 64.71$ (-, C-2), 67.93 (-, C-4), 121.69 (+, Aromatic-C), 124.41 (C quart, Aromatic-C), 126.68 (+, Aromatic-C), 127.78 (+, Aromatic-C), 128.47 (+, Aromatic-C), 130.32 ( $\mathrm{C}_{\text {quart }}$, AomaticC), $131.32\left(\mathrm{C}_{\text {quart }}, \mathrm{C}-10 \mathrm{~b}^{*}\right), 134.42\left(\mathrm{C}_{\text {quart }}, \mathrm{C}-4 \mathrm{a}^{*}\right), 173.68\left(\mathrm{C}_{\text {quart }}, \mathrm{COOCH}_{3}\right) .-\mathrm{MS}(\mathrm{EI}$, $70 \mathrm{eV}), \quad \mathrm{m} / \mathrm{z} \quad(\%): \quad 244$ (54) $\quad\left[\mathrm{M}^{+}\right], \quad 184 \quad(100) \quad\left[\left(\mathrm{M}^{+}-\mathrm{H}\right)-\mathrm{COOCH}_{3}\right], 155$ (69) $\left[\mathrm{M}^{+}-\mathrm{COOCH}_{3}-\mathrm{H}_{2} \mathrm{C}=\mathrm{O}\right], 129$ (14); (DCI, $\left.\mathrm{NH}_{3}, 70 \mathrm{eV}\right) \mathrm{m} / \mathrm{z}(\%): 506$ (13) [2M+N $\left.\mathrm{NH}_{4}^{+}\right]$, 279 (16) $\left[\mathrm{M}+\mathrm{N}_{2} \mathrm{H}_{7}^{+}\right], 262(100)\left[\mathrm{M}+\mathrm{NH}_{4}^{+}\right] .-\mathrm{C}_{15} \mathrm{H}_{16} \mathrm{O}_{3}(244.3)$

Palladium catalysed oligocyclization of Dimethyl 2-(2' '-bromoallyl)-2-(11'-oxo-3',9'dodecadiynyl)malonate (144)

By adapting GP8 method A, $120 \mathrm{mg}(0.55 \mathrm{mmol})$ of palladium acetate was added at 60 ${ }^{\circ} \mathrm{C}$ to a degassed mixture, placed in a Pyrex ${ }^{\circledR}$ crucible, of $350 \mathrm{mg}$ (1.35 mmol) of triphenylphosphine, $2.24 \mathrm{~g}$ (16.2 mmol) of potassium carbonate, and $2.3 \mathrm{~g}$ (5.42 mmol) of dimethyl 2-(2"-bromoallyl)-2-(11'-oxo-3',9'-dodecadiynyl)malonate(144) in $80 \mathrm{ml}$ 
acetonitrile. After stirring at $60{ }^{\circ} \mathrm{C}$ for $12 \mathrm{~h}$, the reaction mixture was cooled and filtered over two layers of Celite ${ }^{\circledR}$ and silica gel. The resulting fitrate was concentrated and the residue was purified by column chromatography (50g silica gel and 2:1 pentane/diethyl ether) to afford the following two fractions:

\section{Fraction II}

Dimethyl 9-acetyl-8-methylenetricyclo[7.4.0.0 $\quad$ 2,7 $]$ trideca-1,6-diene-5,5-dicarboxylat (146)

The second fraction $\left(\mathrm{R}_{\mathrm{f}}=0.14,5: 1\right.$ pentane/diethyl ether) from the plates' top afforded $430 \mathrm{mg}(23 \%)$ of the title compound as a gummy yellowish material .- IR (KBr): $v=$ $2937 \mathrm{~cm}^{-1}$, 1729, 1703, 1434, 1357, 1263, 1068, 906, 835.- ${ }^{1} \mathrm{H}-$

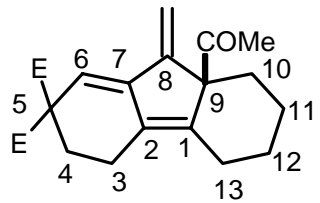
NMR (250 MHz, $\left.\mathrm{CDCl}_{3}\right): \delta=1.10\left(\mathrm{dt}^{2} J={ }^{3} \mathrm{Jax}-\mathrm{ax}=13.1 \mathrm{~Hz}\right.$, ${ }^{3}$ Jax-eq $=4$ Hz, 1 H, 10-H), 1.18 - 1.23 (m, 1 H, 12-H), 1.24 - 1.49 (m, 1 H, 11-H), 1.61 - 1.67 (m, 1 H, 11-H), 1.70 - 1.87 (m, 2 H, 12(13)-H), 1.88 (s, 3 H, COCH $), 2.03$ - 2.14 (m, 1 H, 4-H), 2.24 - 2.32 (m, 1 H, 4-H), 2.54 - 2.62 (m, 4 H, 3(10,13)-H ), 3.74 (s, 3 H, $\mathrm{COOCH}_{3}$ ), 3.75 (s, 3 H, COOCH${ }_{3}$ ), 4.90 (s, $\left.1 \mathrm{H},=\mathrm{CH}_{2}\right), 5.59\left(\mathrm{~s}, 1 \mathrm{H},=\mathrm{CH}_{2}\right), 6.0(\mathrm{~s}, 1 \mathrm{H}, 6-\mathrm{H}) \cdot-{ }^{1} \mathrm{H}-\mathrm{NMR}\left(500 \mathrm{MHz}, \mathrm{CDCl}_{3}\right): \delta=$ $1.08\left(\mathrm{dt},{ }^{2} \mathrm{~J}={ }^{3} \mathrm{Jax}-\mathrm{ax}=13.5 \mathrm{~Hz},{ }^{3} \mathrm{Jax}-\mathrm{eq}=4 \mathrm{~Hz}, 1 \mathrm{H}, 10-\mathrm{H}\right), 1.14$ (dt, ${ }^{3} \mathrm{Jax}-\mathrm{ax}={ }^{3} \mathrm{Jax}-\mathrm{eq}=$ $\left.4 \mathrm{~Hz},{ }^{2} \mathrm{~J}=13.5 \mathrm{~Hz}, 1 \mathrm{H}, 12-\mathrm{H}\right), 1.37$ (tq, $\left.{ }^{2} \mathrm{~J}=3 \mathrm{~Hz},{ }^{3} \mathrm{~J}=13.5 \mathrm{~Hz}, 1 \mathrm{H}, 11-\mathrm{H}\right), 1.60-1.65$ (m, 1 H, 11-H), 1.70 - 1.80 (m, 2 H, 12(13)-H), 1.87 (s, 3 H, COCH $), 2.01$ - 2.11 (m, 1 H, 4-H), 2.23 - 2.29 (m, 1 H, 4-H), 2.51 - 2.60 (m, 4 H, 3(10,13)-H), 3.74 (s, 3 H, $\left.\mathrm{COOCH}_{3}\right), 3.75$ (s, 3H, $\left.\mathrm{COOCH}_{3}\right), 4.90\left(\mathrm{~s}, 1 \mathrm{H},=\mathrm{CH}_{2}\right.$ ), $5.50\left(\mathrm{~s}, 1 \mathrm{H},=\mathrm{CH}_{2}\right), 6.0(\mathrm{~s}, 1 \mathrm{H}$, 6-H).- ${ }^{13} \mathrm{C}-\mathrm{NMR}\left(125.707 \mathrm{MHz}, \mathrm{CDCl}_{3}, \mathrm{APT}\right): \delta=19.54$ (-, C-3) , 23.56 (-, C-11), 25.72 (-, C-13), 25.79 (+, $\mathrm{COCH}_{3}$ ), 26.64 (-, C-12), 28.57 (-, C-4), 33.52 (-, C-10), 52.84 (+, $\mathrm{COOCH}_{3}$ ), 52.85 (+, $\mathrm{COOCH}_{3}$ ), 55.14 (-, C-5), 67.26 (-, C-9), $107.19\left(-,=\mathrm{CH}_{2}\right), 110.28$ (+, C-6), 132.58 (-, C-2), 143.23 (-, C-7*), 143.29 (-, C-1* ), 148.47 (-, C-8), 171.11 (-, $\left.\mathrm{COOCH}_{3}\right), 171.44\left(-, \mathrm{COOCH}_{3}\right), 207.04\left(-, \mathrm{COCH}_{3}\right)$.- MS ( EI, $\left.70 \mathrm{eV}\right), \mathrm{m} / \mathrm{z}(\%): 344$ (12) $\left[\mathrm{M}^{+}\right], \quad 301$ (100) $\left[\mathrm{M}^{+}-\mathrm{COCH}_{3}\right], 242$ (8) $\left[\mathrm{M}^{+}-\mathrm{COOCH}_{3}-\mathrm{COCH}_{3}\right], 241$ (32) [( $\left.\left.\mathrm{M}^{+}-\mathrm{H}\right)-\mathrm{COOCH}_{3}-\mathrm{COCH}_{3}\right], 209$ (6), 183 (4), 155 (6), 43 (0.7) $\left[\mathrm{C}_{2} \mathrm{H}_{3} \mathrm{O}^{+}\right] .-\mathrm{C}_{20} \mathrm{H}_{24} \mathrm{O}_{5}$ (344.4): found 344.1624 (HRMS correct). 


\section{Fraction III}

Dimethyl 9-acetyltricyclo[8.4.0.0 2,7]tetradeca-1(10),2(7),8-triene-5,5-dicarboxylat (147) The second fraction $\left(\mathrm{R}_{\mathrm{f}}=0.08\right.$, 5:1 pentane/diethyl ether) from the plates' top afforded $213 \mathrm{mg}(11 \%)$ of the title compound as a white solid.-IR (KBr): $v=2956 \mathrm{~cm}^{-1}, 1752$,<smiles>CC(=O)c1cc2c(c3c1CCC(F)(F)C3)CCCC2</smiles>
1731, 1677, 1433, 1278, 1079.- ${ }^{1} \mathrm{H}-\mathrm{NMR}\left(250 \mathrm{MHz}^{\mathrm{CDCl}}\right)$ ): $\delta=1.66$ - 1.82 (m, 4 H, 12(13)-H), 2.34 (t, $\left.{ }^{3} J=6.7 \mathrm{~Hz}, 2 \mathrm{H}, 4-\mathrm{H}\right), 2.53$ (m, 5 $\left.\mathrm{H}, 14-\mathrm{H}, \mathrm{COCH}_{3}\right), 2.62\left(\mathrm{t},{ }^{3} \mathrm{~J}=6.7 \mathrm{~Hz}, 2 \mathrm{H}, 3-\mathrm{H}\right), 2.90\left(\mathrm{t},{ }^{3} \mathrm{~J}=6.2 \mathrm{~Hz}\right.$, 2 h, 11-H), 3.28 (s, 2 H, 6-H), 3.72 (s, 6 H, $\mathrm{COOCH}_{3}$ ), 7.24 (s, 1 H, 8H). ${ }^{1} \mathrm{H}-\mathrm{NMR}\left(500 \mathrm{MHz}, \mathrm{CDCl}_{3}\right): \delta=1.68(\mathrm{~m}, 2 \mathrm{H}, 12-\mathrm{H}), 1.79(\mathrm{~m}, 2$ H, 13-H), 2.34 (t, $\left.{ }^{3} J=6 \mathrm{~Hz}, 2 \mathrm{H}, 4-\mathrm{H}\right), 2.53$ (s, $\left.3 \mathrm{H}, \mathrm{COCH}_{3}\right), 2.56$ (t, ${ }^{3} \mathrm{~J}=6.2 \mathrm{~Hz}, 2 \mathrm{H}$, 14- H), 2.60 (t, $\left.{ }^{3} \mathrm{~J}=6.5 \mathrm{~Hz}, 2 \mathrm{H}, 3-\mathrm{H}\right), 2.95$ (t, $\left.{ }^{3} \mathrm{~J}=6 \mathrm{~Hz}, 2 \mathrm{H}, 11-\mathrm{H}\right), 3.28$ (s, $\left.2 \mathrm{H}, 6-\mathrm{H}\right)$, 3.72 (s, $\left.6 \mathrm{H}, \mathrm{COOCH}_{3}\right), 7.24$ (s, $\left.1 \mathrm{H}, 8-\mathrm{H}\right) \cdot-{ }^{13} \mathrm{C}-\mathrm{NMR}\left(125.707 \mathrm{MHz}, \mathrm{CDCl}_{3}, \mathrm{DEPT}\right.$, $62.5 \mathrm{MHz}): \delta=22.51$ (-, C-13*), 22.51 (-, C-12*), 23.75 (-, C-3), 26.93 (-, C-14), 28.08 (-, C-4 ), 28.26 (-, C-11), 30.12 (+, $\left.\mathrm{COCH}_{3}\right), 35.04$ (-, C-6), 52.68 (+, $\left.\mathrm{COOCH}_{3}\right), 52.81$ (+, $\left.\mathrm{COOCH}_{3}\right), 52.93$ (C quart, C-5), 126 (+, C-8), 129.97 ( $\mathrm{C}_{\text {quart }}$, Aromatic-C), 134.72 ( $\mathrm{C}_{\text {quart }}$, Aromatic-C), 136.50 ( $\mathrm{C}_{\text {quart }}$, Aromatic-C), 136.56 ( $\mathrm{C}_{\text {quart }}$, Aromatic-C), 136.79 ( $\mathrm{C}_{\text {quart }}$, Aromatic-C), $171.59\left(\mathrm{C}_{\text {quart }}, \mathrm{COOCH}_{3}\right), 202.74\left(\mathrm{C}_{\text {quart }}, \mathrm{COCH}_{3}\right) .-\mathrm{MS}(\mathrm{EI}, 70 \mathrm{eV})$, m/z (\%): 344 (100) $\left[\mathrm{M}^{+}\right], 329$ (17) $\left[\mathrm{M}^{+}-\mathrm{CH}_{3}\right], 301$ (3) $\left[\mathrm{M}^{+}-\mathrm{COCH}_{3}\right], 285$ (23) $\left[\mathrm{M}^{+}-\mathrm{COOCH}_{3}\right], 284(58)$ [(M+-H)-COOCH 3$], 269$ (19) [( $\left.\left.\mathrm{M}^{+}-\mathrm{H}\right)-\mathrm{COOCH}_{3}-\mathrm{CH}_{3}\right], 241$ (11) $\left[\left(\mathrm{M}^{+}-\mathrm{H}\right)-\mathrm{COOCH}_{3}-\mathrm{COCH}_{3}\right], 225$ (13) [( $\left.\left.\mathrm{M}^{+}-\mathrm{H}\right)-2 \mathrm{COOCH}_{3}\right], 209$ (6), 181 (15), 43 (18) $\left[\mathrm{C}_{2} \mathrm{H}_{3} \mathrm{O}^{+}\right] .-\mathrm{C}_{20} \mathrm{H}_{24} \mathrm{O}_{5}$ (344.4): found 344.1624 (HRMS correct).

5-(tert-butyldimethylsilyloxy)-8-methylenetricyclo[7.4.0.0 $\left.0^{2,7}\right]$ trideca-1(9),2(7)-diene (166)

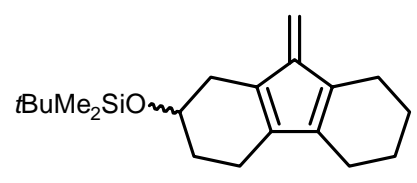

By adapting GP8 method B, $16.82 \mathrm{mg}(0.072 \mathrm{mmol})$ of palladium acetate was added at $80{ }^{\circ} \mathrm{C}$ to a degassed mixture of $49.6 \mathrm{mg}$ (0.18 mmol) of triphenylphosphine, $60 \mathrm{mg}(0.90$ mmol) of sodium formate, and $300 \mathrm{mg}(0.72 \mathrm{mmol})$ of 2-bromo-4-(tertbutyldimethylsilyloxy1)-1-tetradecen-7,13-diyne(117) in $10 \mathrm{ml}$ DMF. After stirring for 2 
$\mathrm{h}$ at $80{ }^{\circ} \mathrm{C}$, the reaction mixture was poured into $100 \mathrm{ml}$ of ammonium chloride solution and extracted $(3 \times 50 \mathrm{ml})$ with diethyl ether. The combined ether layers were dried $\left(\mathrm{MgSO}_{4}\right)$, concentrated and the residue was purified by column chromatography (25 g of flash silica gel and 100:2 pentane/diethyl ether) to afford $127 \mathrm{mg}$ (53\%) of an orange oil. $\left(\mathrm{R}_{\mathrm{f}}=0.60,100: 2\right.$ pentane/diethyl ether).-IR (Film): $v=3079 \mathrm{~cm}^{-1}, 2928,1635,1472$, 1251, 1096, 904, 835, 774, 669.- ${ }^{1} \mathrm{H}-\mathrm{NMR}\left(250 \mathrm{MHz}, \mathrm{CDCl}_{3}\right): \delta=0.08$ (s, $6 \mathrm{H}, \mathrm{TBDMS}-$ H), 0.90 (s, 9 H, TBDMS- H), 1.71 (m, 5 H, 4(11,12)-H), 1.88 (m, 1 H, 4-H), 2.19-2.38 (m, 7 H, 3(6,10)-H), 2.58 (m, 1 H, 6-H), 3.97 (m, $1 \mathrm{H}, 5-\mathrm{H}), 5.44\left(\mathrm{~m}, 2 \mathrm{H},=\mathrm{CH}_{2}\right)$.- ${ }^{1} \mathrm{H}-$ NMR (600 MHz, $\mathrm{CDCl}_{3}$ ): $\delta=0.09$ (s, 6 H, TBDMS-H), 0.90 (s, 9 H, TBDMS-H), 1.70 (m, 5 H, 4(11,12)-H), 1.90 (m, 1 H, 4-H), 2.19 (m, 2 H, 10-H), 2.22 (m, 1 H, 6-H), 2.25 (m, 1 H, 3-H), 2.31 (m, 3 H, 3(13)-H), 2.61 (dd, 1 H, ${ }^{2} J=6$ Hz, $\left.{ }^{3} J=18 \mathrm{~Hz}, 6-\mathrm{H}\right), 3.98(\mathrm{~m}$, $1 \mathrm{H}, 5-\mathrm{H}), 5.44$ (d, ${ }^{2} J=0.5 \mathrm{~Hz}, 1 \mathrm{H},=\mathrm{CH}_{2}$ ), 5.45 (d, $\left.{ }^{2} J=0.5 \mathrm{~Hz}, 1 \mathrm{H},=\mathrm{CH}_{2}\right) \cdot-{ }^{13} \mathrm{C}-\mathrm{NMR}$ (150.82 MHz, $\mathrm{CDCl}_{3}, \mathrm{DEPT}, 62.5 \mathrm{MH}$ ): $\delta=-4.68$ (+, TBDMS-C), -4.62(+, TBDMS-

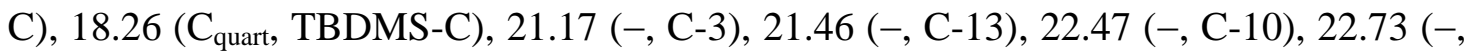
C-11*), 22.89 (-, C-12), 25.92 (+, TBDMS-C), 31.41 (-, C-6), 32.35 (-, C-4), 69.27 (+, C-5), 111.09 (-, = $\mathrm{CH}_{2}$ ), 125.47 ( $\left.\mathrm{C}_{\text {quart }}, \mathrm{C}-9\right), 128.30$ ( $\left.\mathrm{C}_{\text {quart }}, \mathrm{C}-7\right), 140.67$ ( $\mathrm{C}_{\text {quart }}, \mathrm{C}-1^{*}$ ),

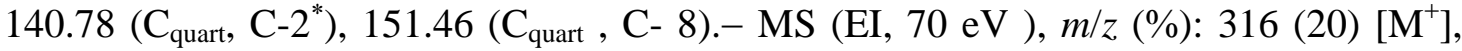
259 (13) $\left[\mathrm{M}^{+}-\mathrm{C}\left(\mathrm{CH}_{3}\right)_{3}\right], 186$ (8) $\left[\mathrm{M}^{+}-\mathrm{t}-\mathrm{BuMe}{ }_{2} \mathrm{SiO}\right], 185$ (10) $\left[\left(\mathrm{M}^{+}-\mathrm{H}\right)-\mathrm{t}-\mathrm{BuMe}_{2} \mathrm{SiO}\right]$, 158 (100) [( $\left.\left.\mathrm{M}^{+}-\mathrm{H}\right)-\mathrm{t}-\mathrm{BuMe}{ }_{2} \mathrm{SiO}-\mathrm{C}_{2} \mathrm{H}_{4}\right], 143$ (4).- $\mathrm{C}_{20} \mathrm{H}_{32} \mathrm{OSi}$ (316.5) found: 316.2222 (HRMS correct).

Palladium catalysed oligocyclization of 15-bromo-13-(tert-butyldimethylsilyloxy)-15hexadecen-3,9-diyn-2-one (145)

By adapting GP8 method B, $15.3 \mathrm{mg}(0.068 \mathrm{mmol})$ of palladium acetate was added at 80 ${ }^{\circ} \mathrm{C}$ to a degassed mixture of $44.7 \mathrm{mg}(0.17 \mathrm{mmol})$ of triphenylphosphine , $70 \mathrm{mg}$ (1 $\mathrm{mmol})$ of sodium formate, and $300 \mathrm{mg}(0.68 \mathrm{mmol})$ of 15-bromo-13-(tertbutyldimethylsilyloxy)-15-hexadecen-3,9-diyn-2-one(145) in 8ml DMF. After stirring from $3 \mathrm{~h}$ at $80{ }^{\circ} \mathrm{C}$, the reaction mixture was poured into $30 \mathrm{ml}$ of water and extracted $(3 \times 20 \mathrm{ml})$ with diethyl ether. The combined ether layers were dried $\left(\mathrm{MgSO}_{4}\right)$, 
concentrated and the residue, which was composed of a complicated mixture of diastereomers, was eluted three times from $20 \times 20 \mathrm{~cm}$ plates coated with thick layer of silica gel (Silica gel $60 \mathrm{PF}_{254}$ containing $\mathrm{CaSO}_{4}$ ) with 20:1 pentane/diethyl ether .The following fractions were separated and identified:

\section{Fraction I}

Fraction I from plates' top $\left(\mathrm{R}_{\mathrm{f}}=0.64,20: 1\right.$ pentane/diethyl ether) provided $12 \mathrm{mg}$ (5\%) of an inseparable 1:1 mixture $\mathbf{1 5 6}$ and $\mathbf{1 5 7}$ as a colorless oil.

$1-\left[\left(7^{\prime} R, 9^{\prime} R, 11^{\prime} S\right)-8^{\prime}\right.$-methylene-11' -(tert-

butyldimethylsilyloxy)tricyclo[7.4.0.0 $\left.{ }^{21,71}\right]$ tridec-1'-en-7'-yl]-1-ethanone (157)

${ }^{1} \mathrm{H}-\mathrm{NMR}\left(600 \mathrm{MHz}, \mathrm{CDCl}_{3}\right.$ ): $\delta=0.06$ (s, $3 \mathrm{H}$, TBDMS-H), 0.08 (s, $3 \mathrm{H}$, TBDMS-H),

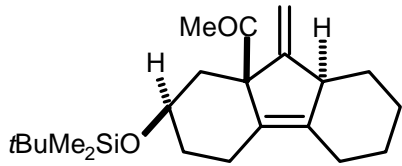

0.86 (s, 9 H, TBDMS-H), 1.12 (t, ${ }^{3} J=11.5 \mathrm{~Hz}, 1 \mathrm{H}, 10^{\prime}-\mathrm{H}$ ), 1.18 (m, $\left.1 \mathrm{H}, 12^{\prime}-\mathrm{H}\right), 1.20$ (m, $\left.1 \mathrm{H}, 6^{\prime}-\mathrm{H}\right), 1.42$ (t, ${ }^{3} \mathrm{~J}=3$ $\left.\mathrm{Hz}, 1 \mathrm{H}, 3^{\prime}-\mathrm{H}\right), 1.6\left(\mathrm{~m}, 1 \mathrm{H}, 13^{\prime}-\mathrm{H}\right), 1.85(\mathrm{~m}, 5 \mathrm{H}$, 3'(4',5',12')-H ), 1.98 (s, 3 H, COCH ${ }_{3}$ ), 2.06 (m, 1 H, 6'-H), 2.45 (dq, ${ }^{2} J=3$ Hz, ${ }^{3} J=13.5$ Hz, 1 H, 13'-H), 2.50 - 2.60 ( m, 1 H, 10'-H), 2.85 (m, 1 H, 9'-H), 4.98 (d, ${ }^{2} J=2$ Hz, 1 H, $\left.=\mathrm{CH}_{2}\right), 5.07\left(\mathrm{~d},{ }^{2} \mathrm{~J}=2.1 \mathrm{~Hz}, 1 \mathrm{H},=\mathrm{CH}_{2}\right) \cdot{ }^{13} \mathrm{C}-\mathrm{NMR}\left(125.7 \mathrm{MHz}, \mathrm{CDCl}_{3}, \mathrm{DEPT}, 62.5\right.$ MHz): $\delta=-4.83$ (+, TBDMS-C), - 4.58 (+, TBDMS-C), 18.18 ( $\mathrm{C}_{\text {quart }}$, TBDMS-C), 22.34 (-, C-13') , 25.55 (+, $\mathrm{COCH}_{3}$ ), 25.87 (+, TBDMS-C), 26.06 (-, C-4'), 26.20 (-, C3'), 27.15 (-, C-5'), 33.93 (-, C-6'), 36.39 (-, C-12'), 43.53 (-, C-10'), 50.92 (+, C-9'), $65.14\left(\mathrm{C}_{\text {quart, }}, \mathrm{C}-7^{\prime}\right), 68.63\left(+, \mathrm{C}-11^{\prime}\right), 108.82\left(+,=\mathrm{CH}_{2}\right), 131.65\left(\mathrm{C}_{\text {quart }}, \mathrm{C}-2^{\prime}\right), 138.43$ (C $\left.\mathrm{C}_{\text {quart, }}, \mathrm{C}-1^{\prime}\right), 156.93$ ( $\mathrm{C}_{\text {quart }}, \mathrm{C}-8$ '), $208.26\left(\mathrm{C}_{\text {quart }}, \mathrm{COCH}_{3}\right) .-\mathrm{MS}(\mathrm{EI}, 70 \mathrm{eV}), \mathrm{m} / \mathrm{z}(\%)$ :

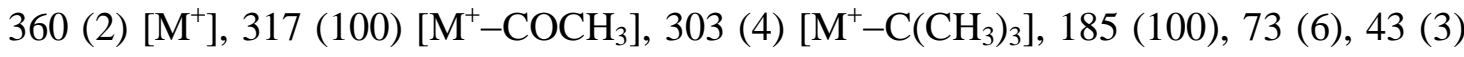
$\left[\mathrm{C}_{2} \mathrm{H}_{3} \mathrm{O}^{+}\right] .-\mathrm{C}_{22} \mathrm{H}_{36} \mathrm{O}_{2} \mathrm{Si}$ (360.6): found 360.2485 (HRMS correct). 


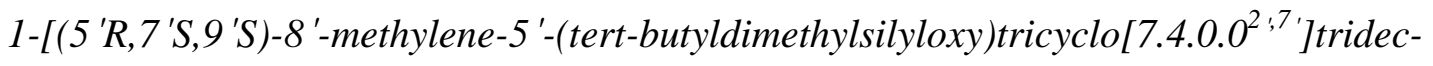
1'-en-7'-yl]-1ethanone (156)

${ }^{1} \mathrm{H}-\mathrm{NMR}\left(600 \mathrm{MHz}, \mathrm{CDCl}_{3}\right.$ ): $\delta=0.02$ (s, $\left.3 \mathrm{H}, \mathrm{TBDMS}-\mathrm{H}\right), 0.04$ (s, $3 \mathrm{H}, \mathrm{TBDMS}-\mathrm{H}$ ), 0.84 (s, $9 \mathrm{H}$, TBDMS-H), 1.06 (dt, ${ }^{3} \mathrm{Jax}-\mathrm{ax}=12.5 \mathrm{~Hz},{ }^{3} \mathrm{Jax}-$

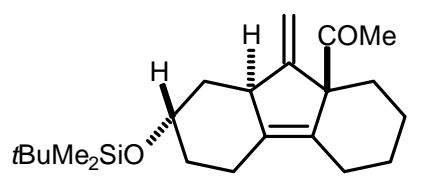
eq $\left.={ }^{2} J=4 \mathrm{~Hz}, 1 \mathrm{H}, 10^{\prime}-\mathrm{H}\right), 1.22\left(\mathrm{~m}, 2 \mathrm{H}, 11^{\prime}-\mathrm{H}\right), 1.28(\mathrm{~m}$, $\left.1 \mathrm{H}, 4^{\prime}-\mathrm{H}\right), 1.36$ (dd, ${ }^{3} J=13.5 \mathrm{~Hz},{ }^{2} J=2.5 \mathrm{~Hz}, 1 \mathrm{H}, 6^{\prime}-\mathrm{H}$ ), 1.40 (m, 2 H, 12'-H), 1.75 (m, 1 H, 4'-H), 1.85 (m, 3 H, 10'(13')-H), 2.09 (s, $3 \mathrm{H}, \mathrm{COCH}_{3}$ ), $2.31-2.34$ (m, $\left.2 \mathrm{H}, 3^{\prime}-\mathrm{H}\right), 2.78$ (dq, ${ }^{2} J=2 \mathrm{~Hz},{ }^{3} J=$ $13.5 \mathrm{~Hz}, 1 \mathrm{H}, 6$ 6'-H), 2.85 (m, 1 H, 9'-H), 4.00 (m, 1 H, 5'-H), 4.81 (d, ${ }^{2} J=2.6 \mathrm{~Hz}, 1 \mathrm{H}$, $\left.=\mathrm{CH}_{2}\right), 4.96\left(\mathrm{~d},{ }^{2} J=2.6 \mathrm{~Hz}, 1 \mathrm{H},=\mathrm{CH}_{2}\right) \cdot{ }^{13} \mathrm{C}-\mathrm{NMR}\left(125.7 \mathrm{MHz}, \mathrm{CDCl}_{3}\right.$, DEPT, 62.5

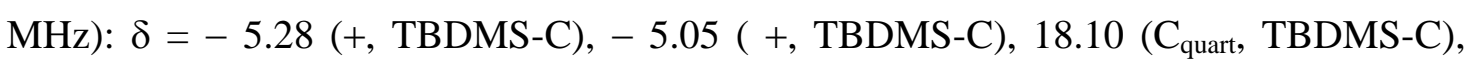
19.49 (-, C-3'), 25.63 (+, $\left.\mathrm{COCH}_{3}\right), 25.81$ (-, C-13'), 25.84 (+, TBDMS-C), 25.93 (-, C12'), 26.66 (-, C-11'), 34.53 (-, C-4'), 34.84 (-, C-10'), 43.32 (-, C-6'), 50.64 (+, C-9'), 67.40 (+, C-5'), $68.91\left(\mathrm{C}_{\text {quart, }}, \mathrm{C}^{\prime} 7^{\prime}\right), 108.19\left(-,=\mathrm{CH}_{2}\right), 131.33\left(\mathrm{C}_{\text {quart }}, \mathrm{C}-2^{\prime}\right), 137.42\left(\mathrm{C}_{\text {quart, }}\right.$

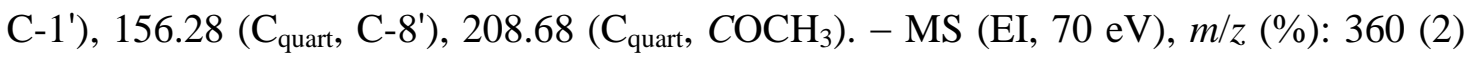
$\left[\mathrm{M}^{+}\right], 317(100)\left[\mathrm{M}^{+}-\mathrm{COCH}_{3}\right], 303$ (4) $\left[\mathrm{M}^{+}-\mathrm{C}\left(\mathrm{CH}_{3}\right)_{3}\right], 185$ (100), 73 (6), 43 (3) $\left[\mathrm{C}_{2} \mathrm{H}_{3} \mathrm{O}^{+}\right]$.- $\mathrm{C}_{22} \mathrm{H}_{36} \mathrm{O}_{2} \mathrm{Si}$ (360.6): found 360.2485 (HRMS correct). 


\section{Fraction IV}

$1-\left[\left(7^{\prime} R, 9^{\prime} S, 11^{\prime} S\right)-8^{\prime}\right.$-methylene-11' -(tert-butyldimethylsilyloxy)tricyclo[7.4.0.0 $\left.0^{2,7_{1}}\right]$ tridec1'-en-7'-yl]-1ethanone (155)

The fourth fraction $\left(\mathrm{R}_{\mathrm{f}}=0.60,20: 1\right.$ pentane/diethyl ether) from the plates' top afforded 20

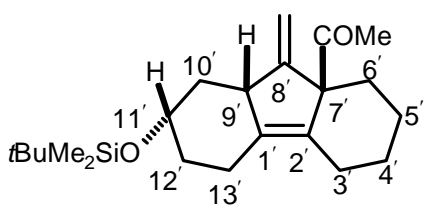
mg (8\%) of the title compound as a colorless oil.-IR (Film): $v=2956 \mathrm{~cm}^{-1} 1,2930,2857,1707,1470,1443$, 1353, 1254, 1100, 1068, 836, 775.- ${ }^{1} \mathrm{H}-\mathrm{NMR}(250 \mathrm{MHz}$, $\left.\mathrm{CDCl}_{3}\right): \delta=0.086(\mathrm{~s}, 6 \mathrm{H}, \mathrm{TBDMS}-\mathrm{H}), 0.89(\mathrm{~s}, 9 \mathrm{H}$, TBDMS- H), 1.00 - 1.44 (m, 5 H, 4'(5',10',12')-H), 1.59 - 1.77 (m, 3 H, 3'(4',5')-H), 1.95 (m,1 H, 13'-H), 1.96 (s, 3 H, $\mathrm{COCH}_{3}$ ), 1.96 - 2.02 (m, 1 H, 12'-H), 2.16-2.26 (m, 1 H, 10'-H), 2.47 - 2.64 (m, 3 H, 3'(6',13')-H), 3.15 - 3.20 (m, 1 H, 9'-H), 3.77 (m, 1 H, 11'-H), $4.87\left(\mathrm{~d},{ }^{2} \mathrm{~J}=2.6 \mathrm{~Hz}, 1 \mathrm{H},=\mathrm{CH}_{2}\right), 4.97\left(\mathrm{~d},{ }^{2} \mathrm{~J}=2 \mathrm{~Hz}, 1 \mathrm{H},=\mathrm{CH}_{2}\right) .-{ }^{1} \mathrm{H}-\mathrm{NMR}(600 \mathrm{MHz}$, $\left.\mathrm{CDCl}_{3}\right): \delta=0.077$ (s, $6 \mathrm{H}$, TBDMS-H), 0.87 (s, $9 \mathrm{H}$, TBDMS-H), $1.04\left(\mathrm{dt},{ }^{2} J={ }^{3} \mathrm{Jax}-\mathrm{ax}=\right.$ $\left.13.5 \mathrm{~Hz},{ }^{3} \mathrm{Jax}-\mathrm{eq}=4 \mathrm{~Hz}, 1 \mathrm{H}, 66^{\prime}-\mathrm{H}\right), 1.08$ (m, $\left.1 \mathrm{H}, 4^{\prime}-\mathrm{H}\right), 1.14$ (q, ${ }^{3} \mathrm{~J}={ }^{2} \mathrm{~J}=12 \mathrm{~Hz}, 1 \mathrm{H}$, 10'-H), 1.23 (m, 1 H, 12'-H), 1.35 (tq, ${ }^{2} J={ }^{3} \mathrm{Jax}-\mathrm{ax}=14 \mathrm{~Hz},{ }^{3} \mathrm{Jax}-\mathrm{eq}=3.5 \mathrm{~Hz}, 1 \mathrm{H}, 5^{\prime}-\mathrm{H}$ ), 1.56 - 1.64 (m, 2 H, 3'(5')-H), 1.72 (m, 1 H, 4'-H), 1.84 -1.92 (m, 1 H, 13'-H), 1.95 (s, 3 H, COCH $\mathrm{CO}_{3}, 1.93$ - 1.98 (m, 1 H, 12'-H), 2.19 (m, 1H, 10'-H), 2.48 (m, 1 H, 3'-H), 2.52 2.60 (m ,2 H, 6'(13')-H), 3.17 (m, 1 H, 9'-H), 3.76 (tt, ${ }^{3} \mathrm{Jax}-\mathrm{ax}=12 \mathrm{~Hz},{ }^{3} \mathrm{Jax}-\mathrm{eq}=4 \mathrm{~Hz}, 1$ H, 11'-H), 4.85 (d, $\left.{ }^{2} J=2 \mathrm{~Hz}, 1 \mathrm{H},=\mathrm{CH}_{2}\right), 4.96$ (d, $\left.{ }^{2} J=1.5 \mathrm{~Hz}, 1 \mathrm{H},=\mathrm{CH}_{2}\right) \cdot-{ }^{13} \mathrm{C}-\mathrm{NMR}$ (150.82 $\mathrm{MHz}, \mathrm{CDCl}_{3}, \mathrm{APT}$ ): $\delta=-4.60$ (+, TBDMS- C), 18.16 (-, TBDMS-C), 22.87 (-, C-13'), $23.91\left(-, \mathrm{C}^{\prime *}{ }^{*}\right), 25.23$ (-, C-3'), 25.85 (+, TBDMS-C), 25.85 (+, $\left.\mathrm{COCH}_{3}\right)$, 27.15 (-, C-5'*), 35.60 (-, C-6'), 35.86 (-, C- 12'), 43.64 (-, C-10'), 48.38 (+, C-9'), 68.85 (-, C-7'), $70.80\left(+, \mathrm{C}-11^{\prime}\right), 108.08$ (-, =CH $\left.\mathrm{CH}_{2}\right), 134.42\left(-, \mathrm{C}-2^{\prime}\right), 135.62\left(-, \mathrm{C}-1^{\prime}\right), 156.39$ (-, C-8'), 208.43 (-, $\left.\mathrm{COCH}_{3}\right)$.- MS (EI, $\left.70 \mathrm{eV}\right), \mathrm{m} / \mathrm{z}$ (\%): 360 (2) [M+1, 317 (32) [M+- $\left.\mathrm{COCH}_{3}\right], 303$ (4) [ $\left.\mathrm{M}^{+}-\mathrm{C}\left(\mathrm{CH}_{3}\right)_{3}\right], 228$ (4), 211 (3), 185 (100), 159 (4), 143 (7), 129 (5), 73 (6), 43 (3) $\left[\mathrm{C}_{2} \mathrm{H}_{3} \mathrm{O}^{+}\right] .-\mathrm{C}_{22} \mathrm{H}_{36} \mathrm{O}_{2} \mathrm{Si}$ (360.6): found 360.2485 (HRMS correct). 


\section{Fraction VI}

1-[12' -(tert-butyldimethylsilyloxy)tricyclo[8.4.0.0 $\left.0^{2,7^{\prime}}\right]$ tetradeca-1' $\left(10^{\prime}\right), 2^{\prime}\left(7^{\prime}\right), 8^{\prime}-$ trien-8'yl]-1-ethanone (158)

The sixth fraction $\left(\mathrm{R}_{\mathrm{f}}=0.35,20: 1\right.$ pentane/diethyl ether) from the plates' top afforded 20<smiles>CC(=O)c1cc2c(c3c1CCCC3)CC[C@H](OC(C)(C)C)C2</smiles>
mg (8\%) of the title compound as a colorless liquid.-IR (Film): $v=2958 \mathrm{~cm}^{-} 1,2927,2855,1709,1681,1564,1467$, 1431, 1355, 1275, 1252, 1100, 884, 836, 776, 627.- ${ }^{1} \mathrm{H}-\mathrm{NMR}$ (250 MHz, $\mathrm{CDCl}_{3}$ ): $\delta=0.096$ (s, $\left.3 \mathrm{H}, \mathrm{TBDMS}-\mathrm{H}\right), 0.099$ (s, 3 H, TBDMS-H), 0.90 (s, 9 H, TBDMS-H), 1.64 - 1.83 (m, 5 H, 4'(5',13')-H), 2.02 (m, 1 H, 13'-H), 2.53 (s, 3 H, COCH ${ }_{3}$ ), 2.54 - 2.59 (m, 3 H, 3'(14')-H), 2.78 - 2.92 (m, 5 H, 6'(11',14')-H), 4.03 (m, 1 H, 12'-H), 7.19 (s, 1 H, 9'-H). ${ }^{1}$ H-NMR (600 MHz, CDCl $): \delta=$ 0.060 (s, 3 H, TBDMS-H), 0.069 (s, 3 H, TBDMS-H), 0.88 (s, 9 H, TBDMS-H), 1.64 1.70 (m, 2 H, 4'(5')-H), 1.72 - 1.82 (m, 3 H, 4'(5',13')-H), 2.00 (m, 1 H, 13'-H), 2.51 (s, 3 H, $\mathrm{COCH}_{3}$ ), 2.52 - 2.62 (m, 3 H, 3'(14')-H), 2.71 - 2.80 (m, 2 H, 11' (14')-H), 2.87 - 2.95 (m, 3 H, 6'(11')-H), 4.03 (m, 1 H, 12'-H), 7.17 (s, 1 H, 9'-H).- ${ }^{13}$ C-NMR (150.82 MHz, $\left.\mathrm{CDCl}_{3}, \mathrm{APT}\right): \delta=-4.65$ (+, TBDMS-C), - 4.61 (+, TBDMS-C) , 18.21 (-, TBDBS-C), 22.67 (-, C-4'), 22.67 (-, C-5'), 25.32 (-, C-14'), 25.87 (+, TBDMS-C), 27.11 (-, C-3'), 28.27 (-, C-6'), 30.11 (+, $\left.\mathrm{COCH}_{3}\right), 32.03$ (-, C-13'), 39.40 (-, C-11'), 67.44 (-, C-12'), 127.51 (+, C-9'), 131.88 (-, Aromatic-C), 134.23 (-, Aromatic-C), 136.31 ( -, AromaticC*), 136.41 (-, C-8**), 138.43 (-, Aromatic-C), 202.74 (-, $\left.\mathrm{COCH}_{3}\right)$.- MS (EI, $70 \mathrm{eV}$ ), m/z (\%): 358 (1) [ $\left.\mathrm{M}^{+}\right], 301$ (100) [ $\left.\mathrm{M}^{+}-\mathrm{C}\left(\mathrm{CH}_{3}\right)_{3}\right], 285$ (7), 227 (7), 185 (15), 75 (13), 43 (8) $\left[\mathrm{C}_{2} \mathrm{H}_{3} \mathrm{O}^{+}\right] .-\mathrm{C}_{22} \mathrm{H}_{34} \mathrm{O}_{2} \mathrm{Si}$ (358.6): found 358.2328 (HRMS correct). 


\section{Conclusion and abstract}

Synthesis of different substituted 2-bromotetradeca-1-ene-7,13-diyne precursors can be easily achieved by using 1,7-octadiyne (60).

The cyclization outcome of these precursors depends on the type of substituent at the terminal triple bond. Thus, when the terminal triple bond bears an electron-withdrawing group, such as a methoxycarbonyl group in 110, a tetracyclic system with an annelated cyclopropane ring, such as 119, will be formed. However, when the triple bond bears an electron releasing trialkylsilyl or phenyl group, such as in $\mathbf{4 8}$, the thermodynamically most stable aromatic compound, of type $\mathbf{7 3}$, will be formed. When the terminal triple bond bears a proton (unsubstituted) $\mathbf{1 1 7}$ or a group with an aptitude for migration, such as 144, fulvene systems 166 and tricyclic systems with an exo-double bond 146 are being formed, respectively.

The cyclization mechanism of these precursors can go via twofold Heck reactions followed by 5-exo-trig carbopalladation (Heck-Heck-5-exo-trig sequence). The variation in the outcome of these precursors excludes the other possibilities, such as intramolecular

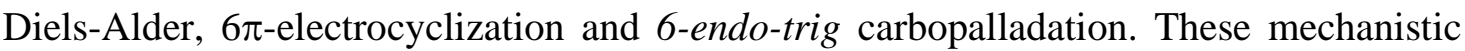
considerations are illustrated in section 8, page 64, and in the Scheme 61 therein.

The geminal substitution at the tether linking the vinyl bromide moiety would affect the yield of such precursors (2-bromotetradeca-1-ene-7,13-diyne), but it has no effect on the outcome of the palladium-catalyzed transformations of these precursors. 


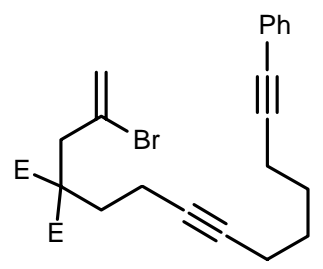

48

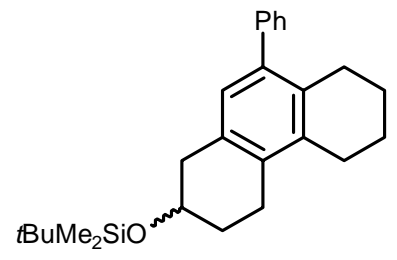

74

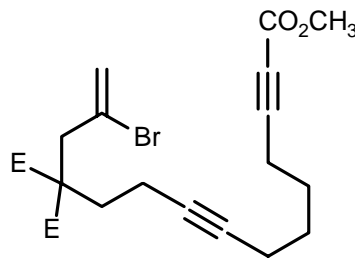

110
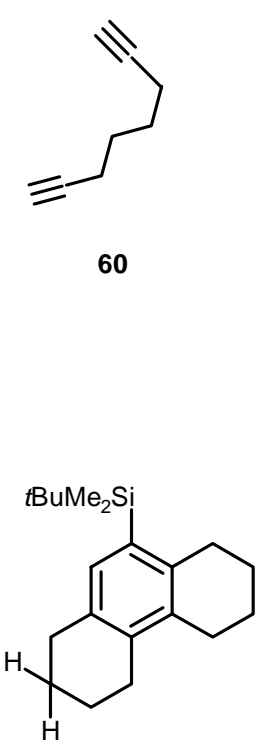

91

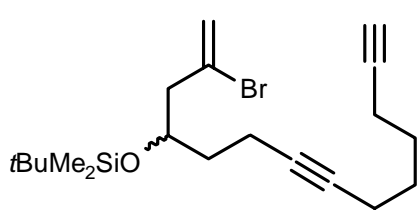

117
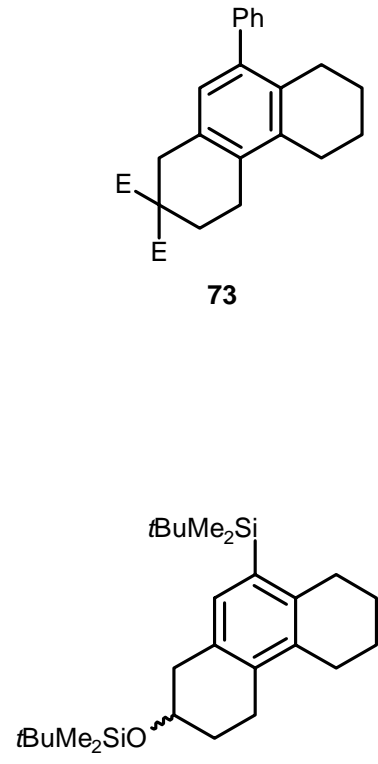

92

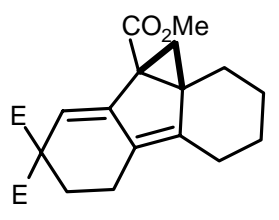

119 


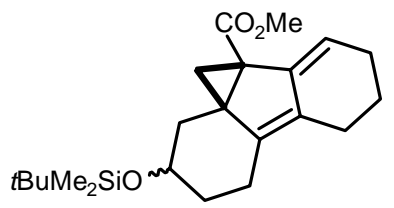

122<smiles>CC(=O)C1CC2=C(CCOC2)c2ccccc21</smiles>

136<smiles>CC(=O)c1cc2c(c3c1CCC(F)(F)C3)CCCC2</smiles>

147

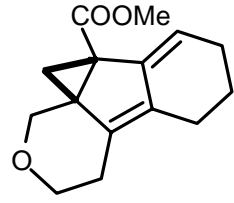

134

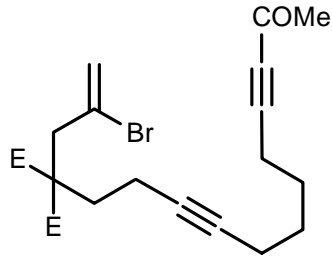

144

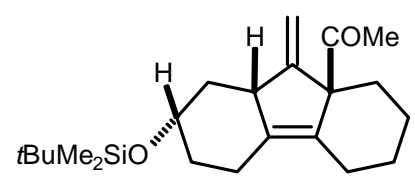

155

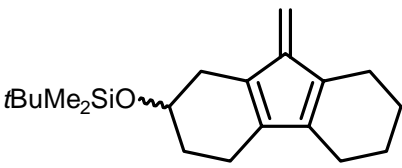

166

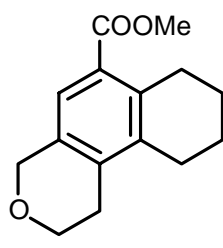

135

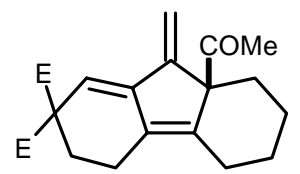

146<smiles>CC(=O)c1cc2c(c3c1CCCC3)CC[C@H](O[SiH2]C(C)(C)C)C2</smiles>

158 


\section{E. References and Literature}

[1] E.Negishi; F. Liu in Metal-Catalyzed Cross-Coupling Reactions (Eds: F. Diederich; P. J. Stang) WILEY-VCH, Weinheim 1998, pp. 1-47.

[2] J. K. Stille, Angew. Chem. Int. Ed. 1986, 25, 508-524; T. N. Mitchell in MetalCatalyzed Cross-Coupling Reactions (Eds: F. Diederich; P. J. Stang) WILEY-VCH, Weinheim, 1998, pp. 167-202.

[3] K. Sonogashira in Metal-Catalyzed Cross-Coupling Reactions (Eds: F. Diederich; P. J. Stang) WILEY-VCH, Weinheim, 1998, pp. 203-229.

[4] A. Suzuki in Metal-Catalyzed Cross-Coupling Reactions (Eds: F. Diederich; P. J. Stang) WILEY-VCH, Weinheim, 1998, pp. 49-91.

[5] K. Alder; F. Pascher; A. Schmitz, Chem. Ber. 1943, 76, 27.

[6] L. F. Tietze; V. Beifuss; M. Ruther, J. Org. Chem. 1989, 54, 3120.

[7] B. M. Trost; D. C. Lee; F. Rise, Tetrahedron Lett. 1989, 30, 651.

[8] B. M. Trost; O. J. Gelling, Tetrahedron Lett. 1993, 34, 8233-8236.

[9] B. M. Trost; D. C. Lee, J. Org. Chem. 1989, 54, 2271.

[10] B. M. Trost,, Acc. Chem. Res. 1990, 23, 34-42.

[11] B. M. Trost; J. M. Tour, J. Am. Chem. Soc. 1987, 109, 5268-5270.

[12] J. M. Takacs; J. J. Wiedner; B. E. Takacs, Tetrahedron Lett. 1990, 31, 2865-2868; J. M. Takacs; J. J. Wiedner; B. E. Takacs, Tetrahedron Lett. 1993, 34, 6219-6222; J. M. Takacs; Y.C. Myoung; L.G. Anderson, J. Org. Chem. 1994, 59, 6928-6942.

[13] F. Sato; H. Urabe, in Titanium and Zirconium in Organic Synthesis (Ed: I. Marek) WILEY-VCH, Weinheim, 2002, PP. 319-354.; S. J. Sturla; N. M. Kablaoui; S. L. Bächwald, J. Am. Chem. Soc. 1999, 121, 1976-1977; for Zirconium see: E. Negishi; S. Huo, in Titanium and Zirconium in Organic Synthesis (Ed: I. Marek) WILEY-VCH, Weinheim, 2002, pp. 1-49.; S. Dixon; R. J. Whitby, in Titanium and Zirconium in Organic Synthesis (Ed: I. Marek) WILEY-VCH, Weinheim, 2002, pp.86-109.

[14] N. Chanti; N. Furukawa,; H. Sakurai,; S. Murai, Organometallics, 1996, 15, 901903; C. Fernandez-Riva,; M. Mendez; A. M. Echavarran, J. Am. Chem. Soc. 2000, 122, 
1221-1222.

[15] P. Cao,; X. Zhang, J. Am. Chem. Soc. 2000, 122, 6490-6491.

[16] K. M. Brummond; J. L. Kent, Tetrahedron 2000, 56, 3263-3283.

[17] N. Chanti; H. Inoue; T. Morimoto; T. Muto; S. Nuri, J. Org. Chem. 2001, 66, 44334436.

[18] B. M. Trost; F. D.Toste; A.B. Pinkerton, Chem. Rev. 2001, 101, 2067-2096.

[19] B. M. Trost; F. D. Toste, J. Am. Chem. Soc. 2002, 124, 5025-5036.

[20] C. Aubert; O. Buisine; M. Malacria, Chem. Rev. 2002, 102, 813-834.

[21] A. de Meijere; F. E. Meyer, Angew. Chem. Int. Ed. 1994, 33, 2379-2411.

[22] C. Amatore; A. Justand, Acc. Chem. Res. 2000, 33, 314-321.

[23] K. H. Ang; S. Bräse; A. G. Steinig; F. E. Meyer; A. Llebaria,; K. Voigt,; A. de Meijere, Tetrahedron 1996, 52, 11503-11528.

[24] J. T. Link; L. E. Overman in Metal-Catalyzed Cross-Coupling Reactions (Eds: F. Diederich, P. J. Stang) WILEY-VCH, Weinheim, 1998, pp. 231-269.

[25] L. F.Tietze; U. Beifuss, Angew. Chem. Int. Ed. 1993, 32, 131-163.

[26] S. E. Denmark; A. Thoraensen, Chem. Rev. 1996, 96, 137-165.

[27] D. Nelson; M. M. Cox, Lehninger Principles of Biochemistry, third edition, Worth Publishers. New York. 2000.

[28] H. Henniges, Dissertation, Universität Goettingen, 1994.

[29] J. P. Collman; L. S.Hegedus; J. R.Norton; R. G. Finke, Principles and Applications of Organotransition Metal Chemistry, University Science Books, Mill Vally, 1987, Chapters 3 and 6.

[30] H. Henniges; F. E. Meyer; U. Schick; F. Funke; P. Parsons; A. de Meijere, Tetrahedron 1996, 52, 11545-11578.

[31] Y. Zahang; G. Wu; Angel, G.; E-I. Negishi, J. Am. Chem. Soc. 1990, 112, 85908592.

[32] B. M. Trost; Y. Shi; J. Am. Chem. Soc. 1993, 115, 12491-12509.

[33] S. Schweizer, Dissertation, Universität Goettingen, 1998.

[34] S. Schweizer; M. Schelper; C. Thies; P. J. Parsons; M. Noltmeyer; A. de Meijere,; Synnlett. 2001, 920-922.

[35] F. E. Meyer; H. Henniges; A. de Meijere, Tetrahedron Lett. 1992, 33, 8039-8042 
[36] J. K. Crandall; W. J. Michaely, J. Org. Chem. 1984, 49, 4244-4248.

[37] W. F. Baily, N. M. Wachter-Jurcsak; M. R. Pineau; T. V. Ovaska; R. R. Warren,; C. E. Lewis, J. Org. Chem. 1996, 61, 8216-8228.

[38] L. Brandsama, Preparative Acetylenic Chemistry, Elsevier Verlag, Amestrdam, 1988

[39] P. E. Sonnet, Synthetic Communications, 1976, 6(1), 21-26.

[40] J. Clayden; N. Greeves; S. Warren; P. Wothers; Organic Chemistry, Oxford University Press, New York, 2001.

[41] G. L. Larson; R. J. Klesse, Org. Chem. 1985, 50, 3627.

[42] R. M. Coates; S. J. Hobbs, J. Org. Chem. 1984, 49, 140-152; B. Feringa, Synthetic Communication, 1985, 15(2), 87-89.

[43] A. J. Mancuso; D. Swern; Synthesis,1981, 165

[44] E. R. H. Jones; G. Eglinton; M. C. Whiting, Org. Synthesis. coll. vol IV. Wiley, New York, 1963, 755.

[45] B. S. Furiness; A. J. Hannaford; P. W. G. Smith; A. R. Tatchell, Vogel's Textbook of Organic Chemistry. fifth edition, Longman Group, U.K.,1989.

[46] F. D. Gunstone; P. J. Sykes, J. Chem. Soc. 1962, 3055-3058.

[47] T. Mandai; J. Nokami; T. Yano; Y. Yoshinaga; J. Otera; J. Org. Chem. 1984, 49,172-174.

[48] A. Llebaria; Research Report; University of Goettingen. 1993.

[49] J. J. Tafariello; E. Trybulski; J. Org. Chem. 1974, 39, 3378-3384.

[50] S. Hara; H. Dojo; S. Takinami; A. Suzuki, Tetrahedron Lett. 1983, 24, 731-734.

[51] Y. Makioka; Y. Taniguchi; T. Kitamura; Y. Fujiwara; A. Saiki; K. Takaki, Bull. Soc. Chim. Fr. 1997, 134, 349-355.

[52] E. J. Corey; A. Venkateswarlu, J. Am. Chem. Soc. 1972, 94, 6190.

[53] C. Thies, Dissertation, Universität Goettingen, 1999.

[54] T. D. W. Claridge; High-Resolution NMR Techniques in Organic Chemistry. Pergamon, An imprint of Elsevier Science, Amsterdam, 1999.

[55] J-E. Bäckvall; R. B. Hopkins; H. Grennberg; M. M. Mader; A. K. Awasthi, J. Am. Chem. Soc. 1990, 112, 5160-5166.

[56] R. Grigg, M. Korbes, Eur. J. Org. Chem. 2001, 707-712.

[57] S. Copper; P. G. Sammes; J. Chem. Soc. Perkin I. 1984, 2407-2413; P. Schiess; P. 
Funfschilling, Tetrahedron Lett. 1972, 5195-5198.

[58] See for example : I. W. J. Still; T. Sang; Tetrahedron Lett. 1979, 3613-3614; P. A. Knott; J. M. Mellor, J. Chem. Soc. Perkin Trans I. 1972, 8, 1030-1033.

[59] D. J. Field; D. W. Jones; G. Keen, J. Chem. Soc. Perkin I. 1978, 1050-1058.

[60] T. Nishimura; S. Matsumura; Y. Maeda; S. Uemura, Tetrahedron Lett. 2002, 43, 3037-3039; T. Nishimura; S. Matsumura; Y. Maeda; S. Uemura, Chem. Commun. 2002, 50-51; T. Nishimura; S. Uemura, J. Am. Chem. Soc. 2000, 122, 12049-12050.

[61] M. J. Green; J. P. Britovesk; K. Cavell; B. Skelton; A. White, Chem. Commun. 1996, 1563-1564.

[62] B. Burns; R. Grigg; V. Sridharan; T. Worakun, Tetrahedron Lett. 1988, 29, 43254328.

[63] S. Schweizer; Z-Z. Song; F. E. Meyer; P. J. Parsons; A. de Meijere, Angew. Chem. Int. Ed. 1999, 38, 1452-1454.

[64] F. E. Meyer; P. J. Parsons; A. de Meijere, J. Org. Chem. 1991, 56, 6487-6488.

[65] S. Girard; P. Deslongchamps, Can. J. Chem . 1992, 70, 1256-1273. 


\section{F-Spectral Data}

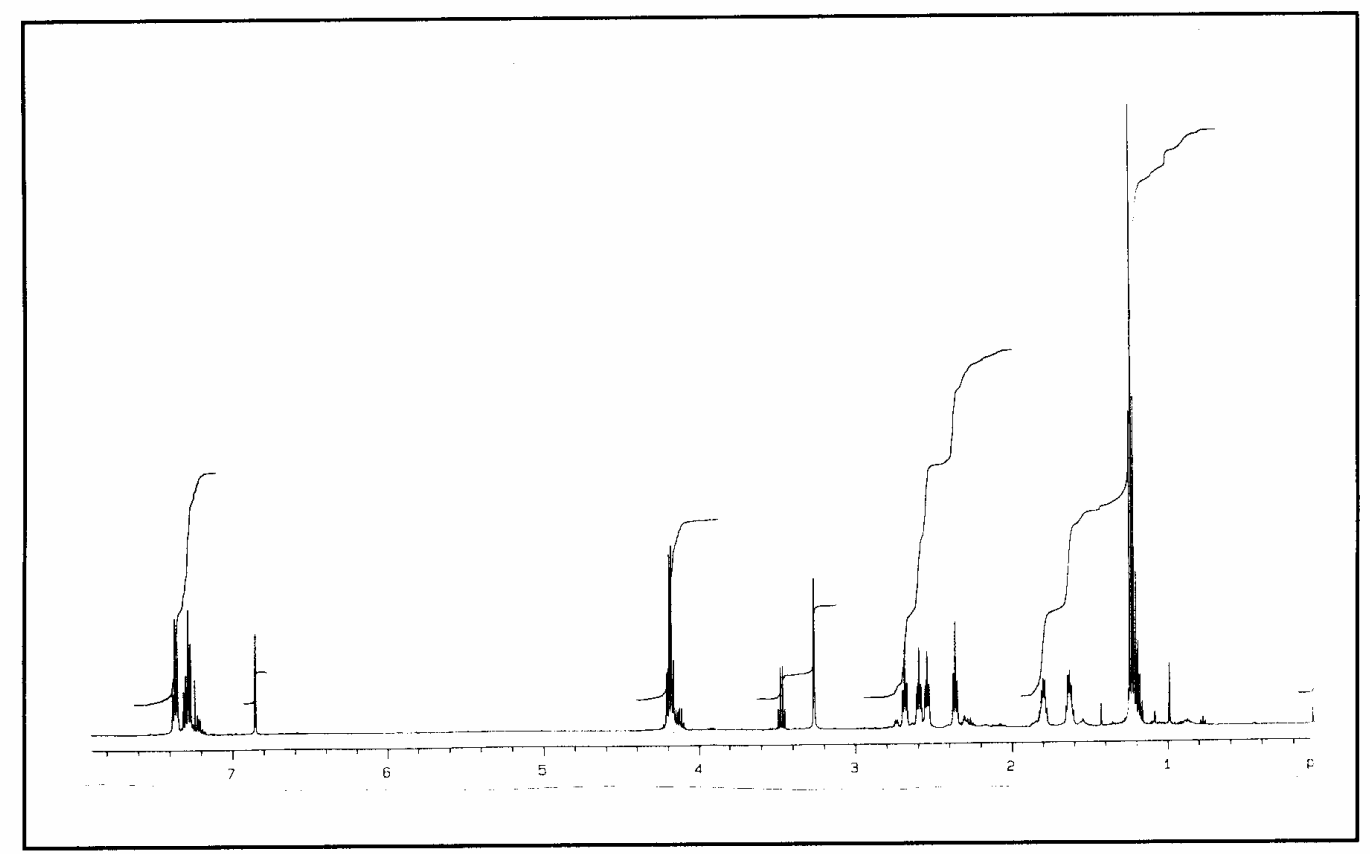

${ }^{1} H-N M R$ spectrum of diethyl 9-phenyltricyclo[8.4.0.0 $\left.0^{2,7}\right]$ tetradeca-1,7,9-triene-5,5dicarboxylate (73)

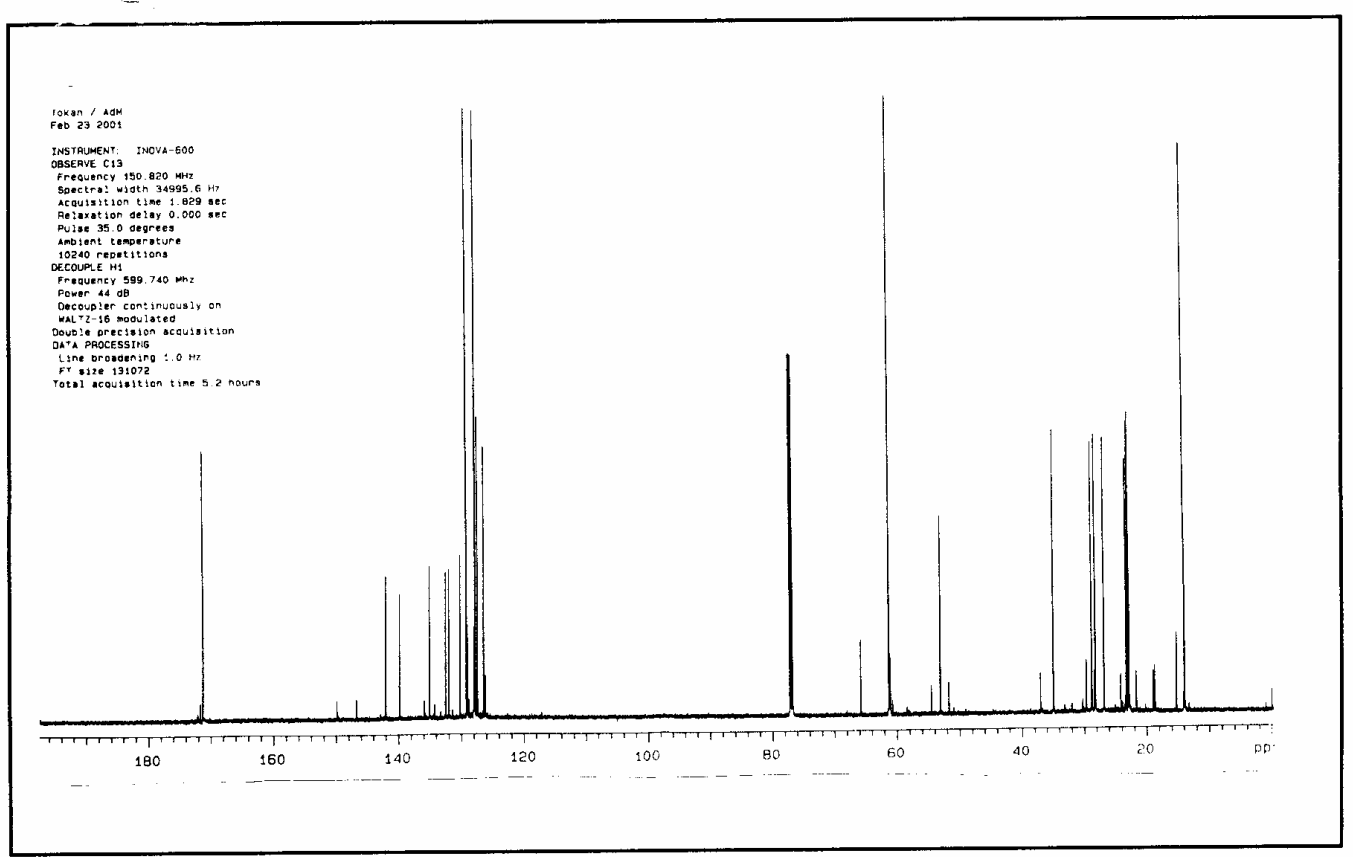

${ }^{13} C-N M R$ spectrum of diethyl 9-phenyltricyclo[8.4.0.0 $\left.0^{2,7}\right]$ tetradeca-1,7,9-triene-5,5dicarboxylate (73) 


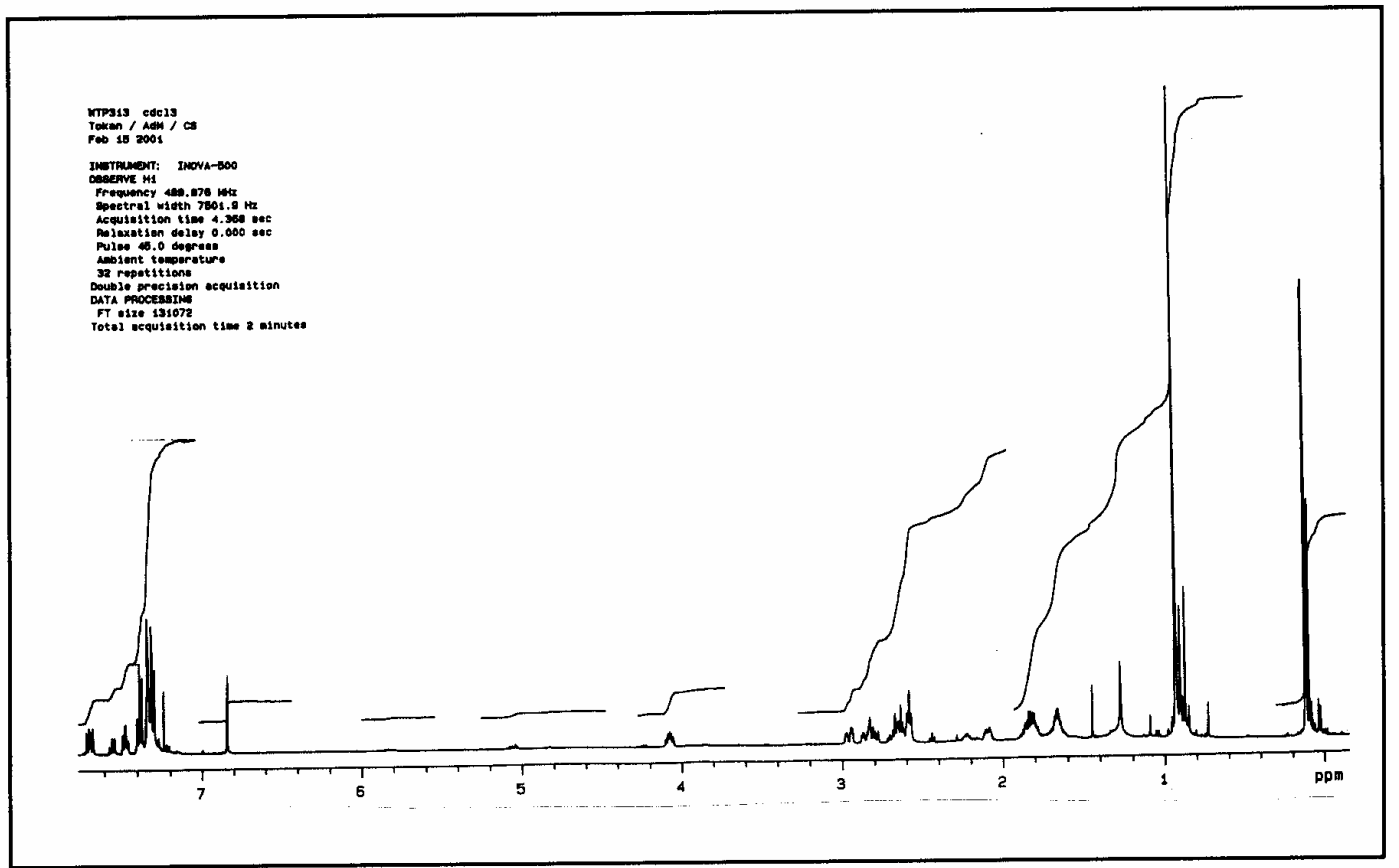

${ }^{I} H$-NMR spectrum of 5-(tert-butyldimethylsilyloxy)-9-phenyltricyclo[8.4.0.0 $\left.0^{2,7}\right]$ tetradeca1,7,9-triene (74)

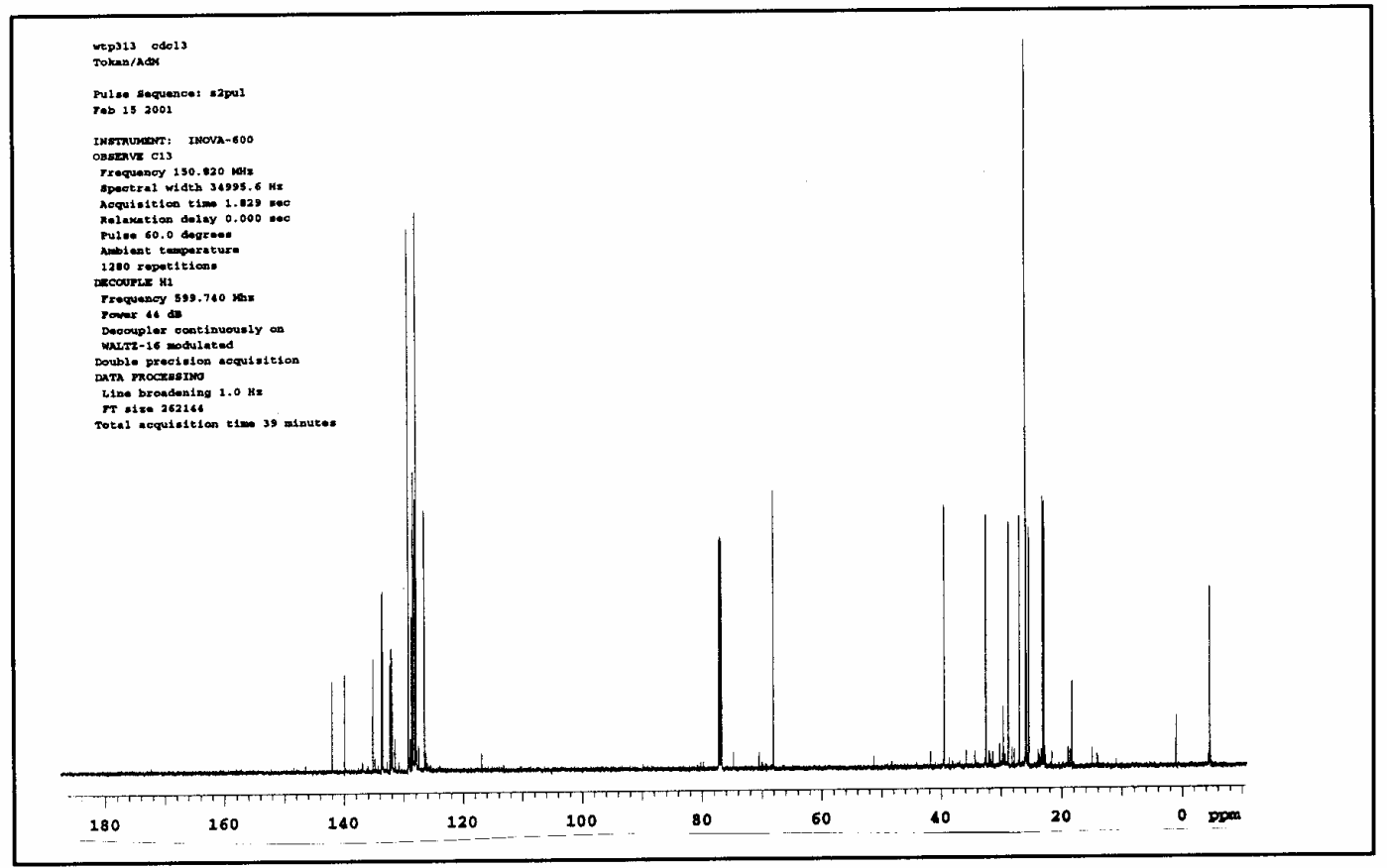

${ }^{13} \mathrm{C}-\mathrm{NMR}$ spectrum of 5-(tert-butyldimethylsilyloxy)-9phenyltricyclo[8.4.0.0 $\left.0^{2,7}\right]$ tetradeca1,7,9-triene(74) 


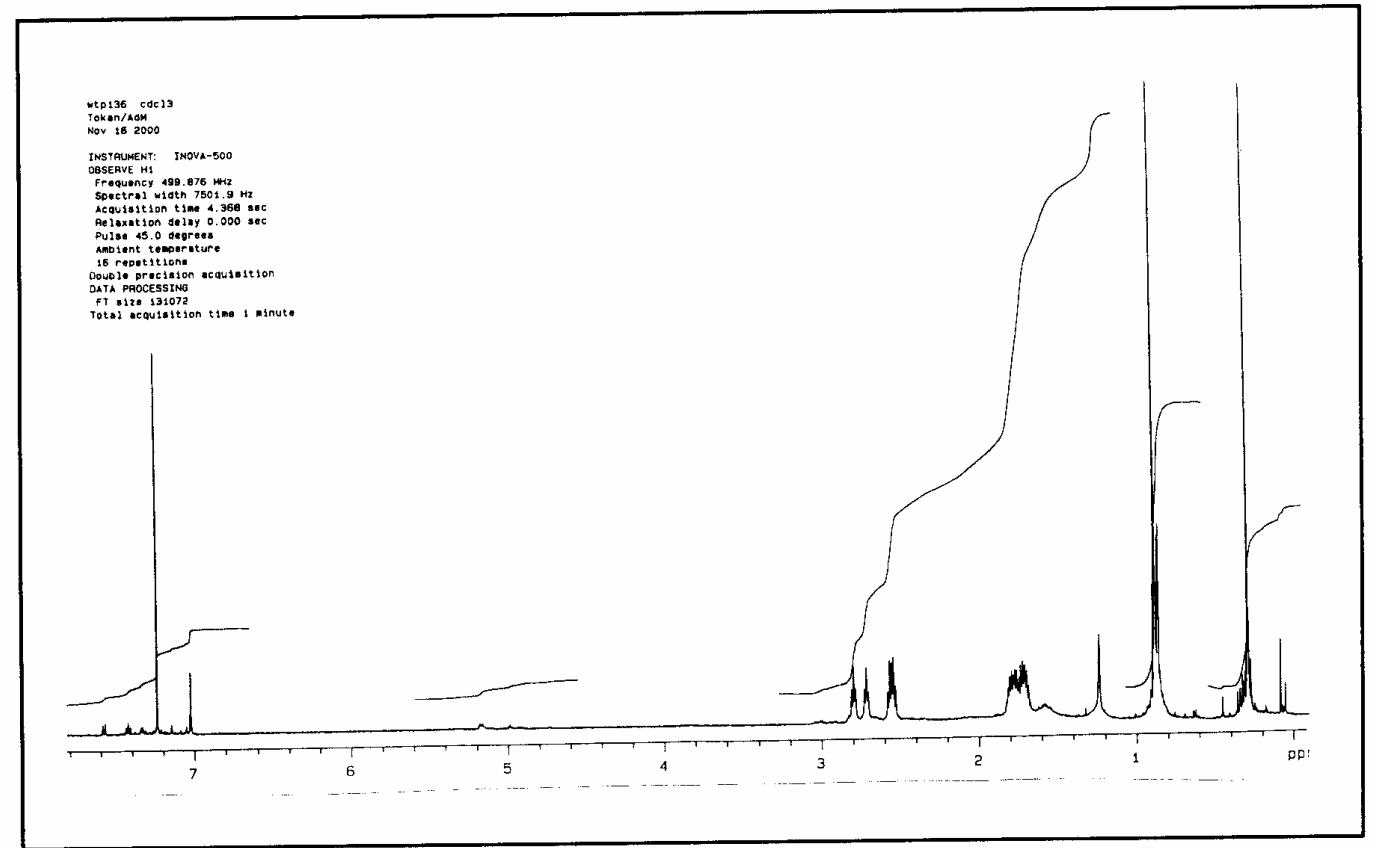

${ }^{1} H$-NMR spectrum of 8-(tert-butyldimethylsilyl)-tricyclo[8.4.0.0 $\left.0^{2,7}\right]$ tetradeca-1,7,9-triene (91)

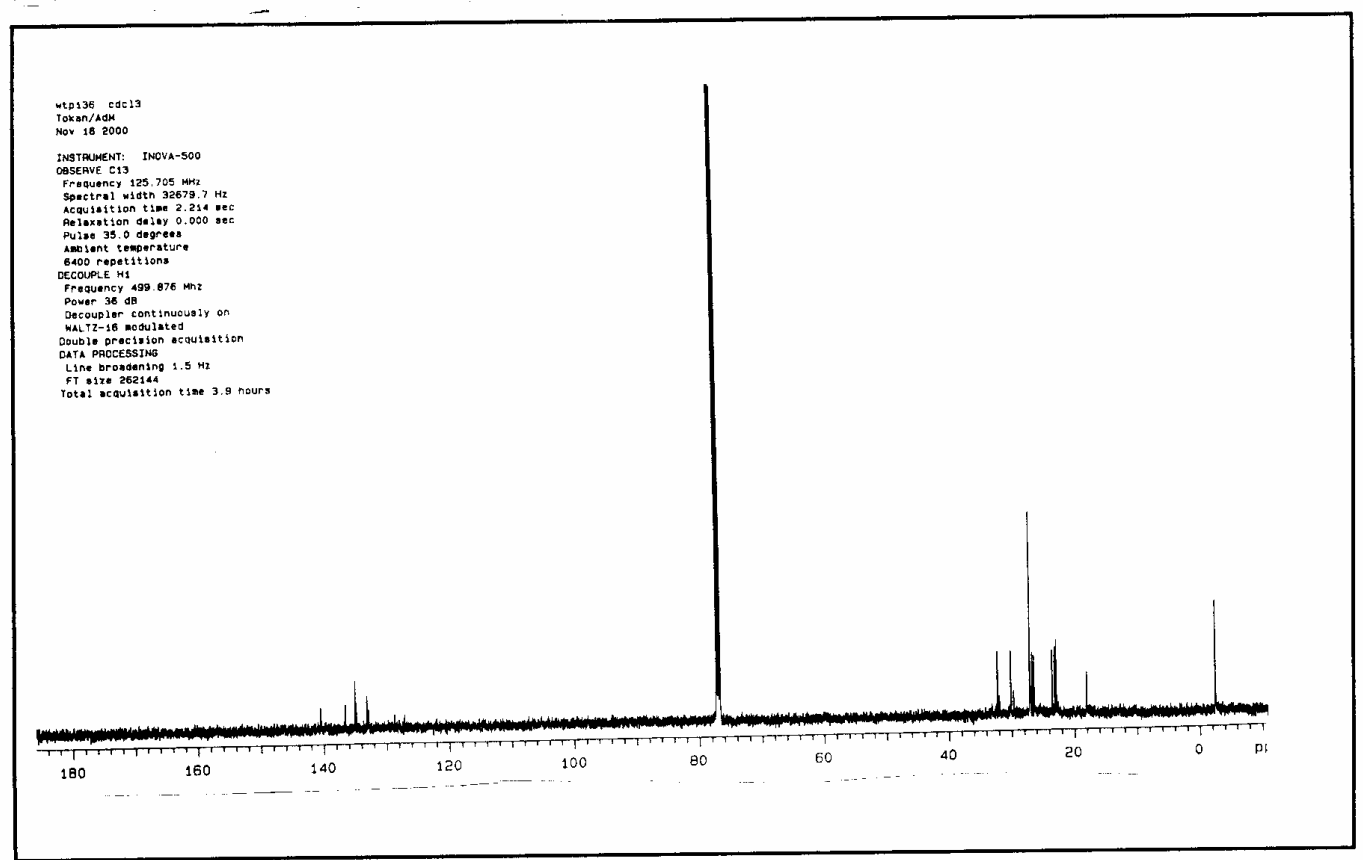

${ }^{13} \mathrm{C}$-NMR spectrum of 8-(tert-butyldimethylsilyl)-tricyclo[8.4.0.0 $\left.0^{2,7}\right]$ tetradeca-1,7,9-triene (91) 


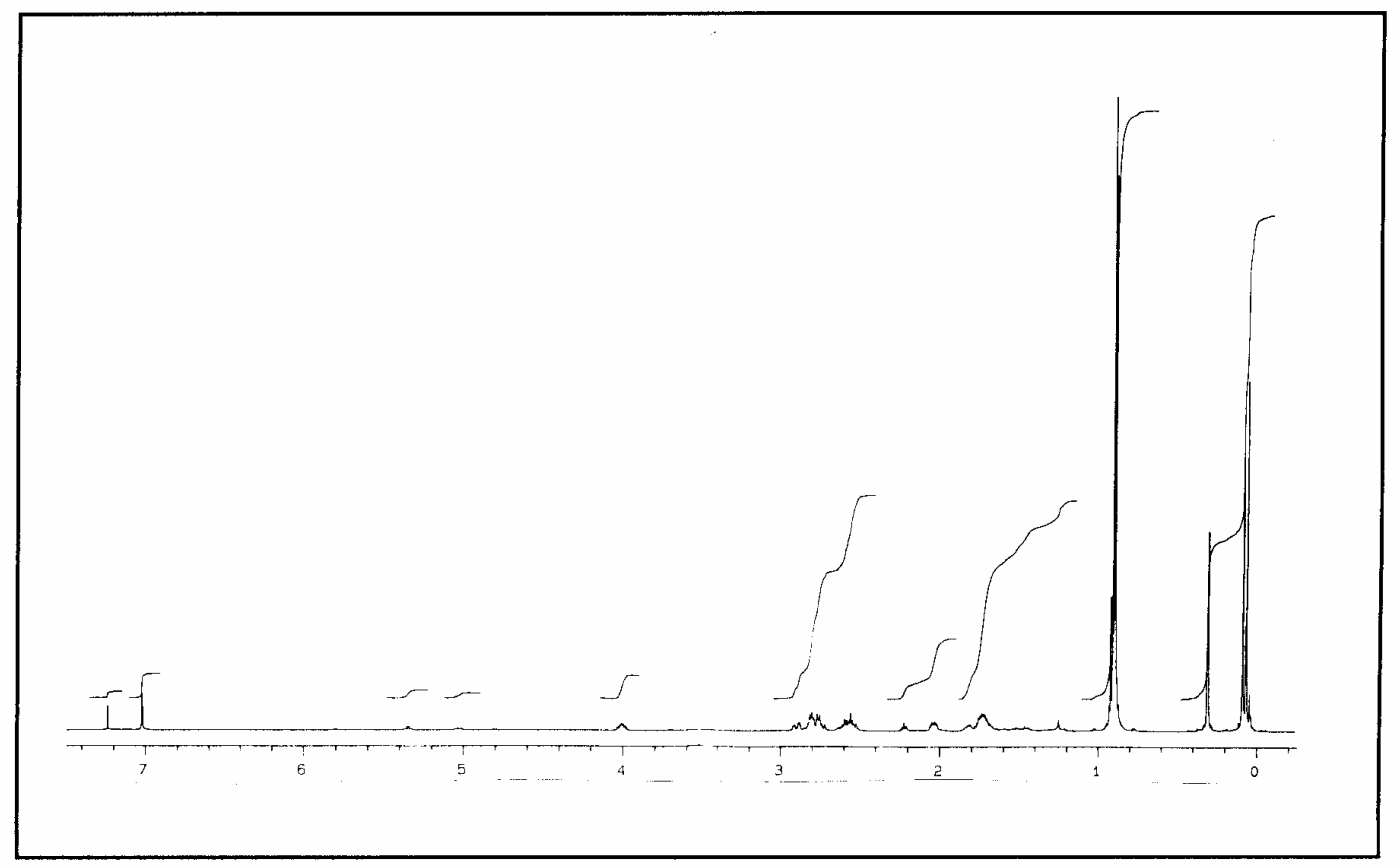

${ }^{I} H-N M R$ spectrum of

5-(tert-butyldimethylsilyloxy)-9-(tertbutyldimethylsilyl)tricyclo[8.4.0.0 $\left.0^{2,7}\right]$ tetradeca-1,7,9triene (92)

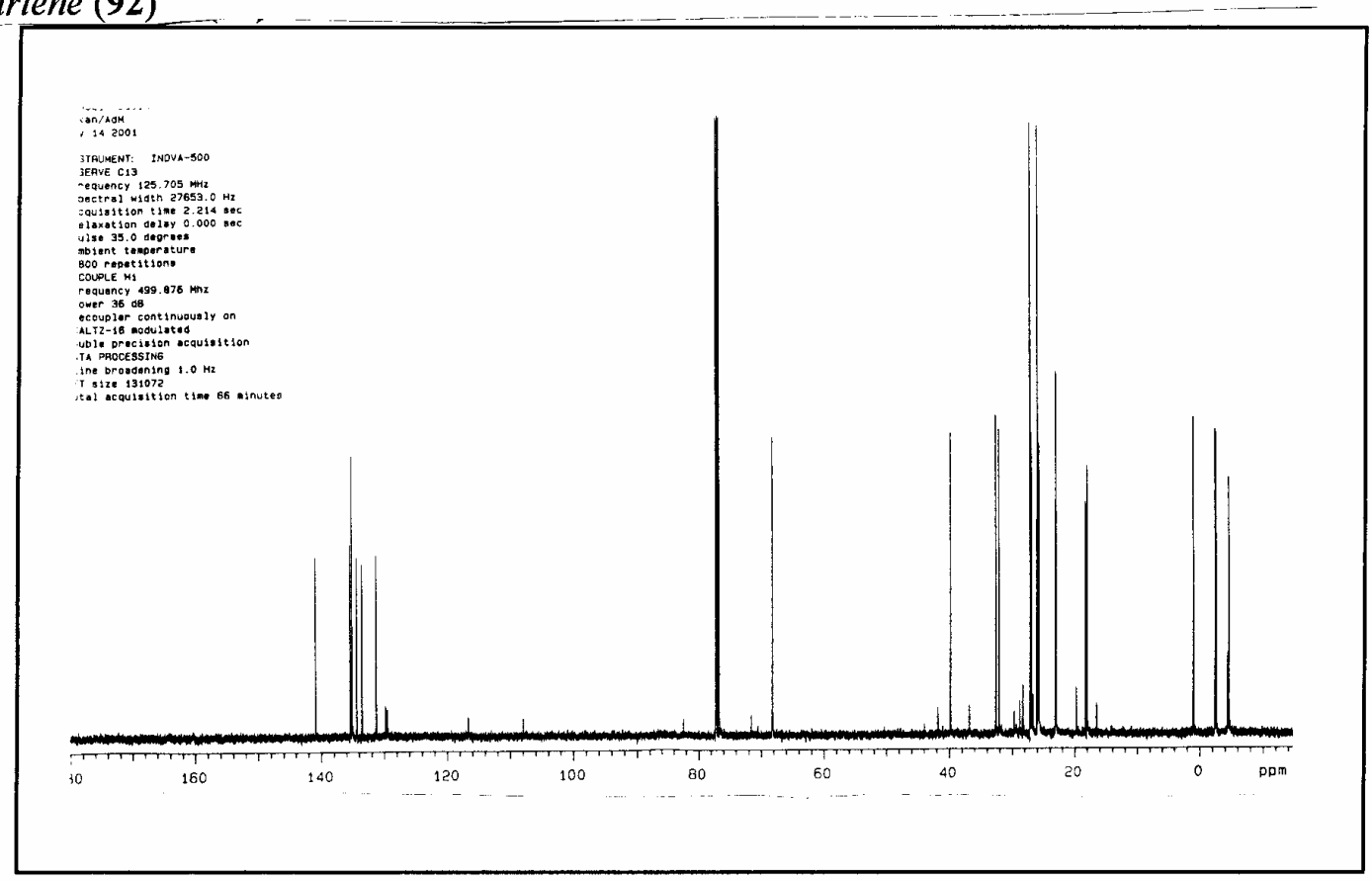

${ }^{13}$ C-NMR spectrum of

5-(tert-butyldimethylsilyloxy)-9-(tertbutyldimethylsilyl)tricyclo[8.4.0.0 $\left.0^{2,7}\right]$ tetradeca-1,7,9triene (92) 


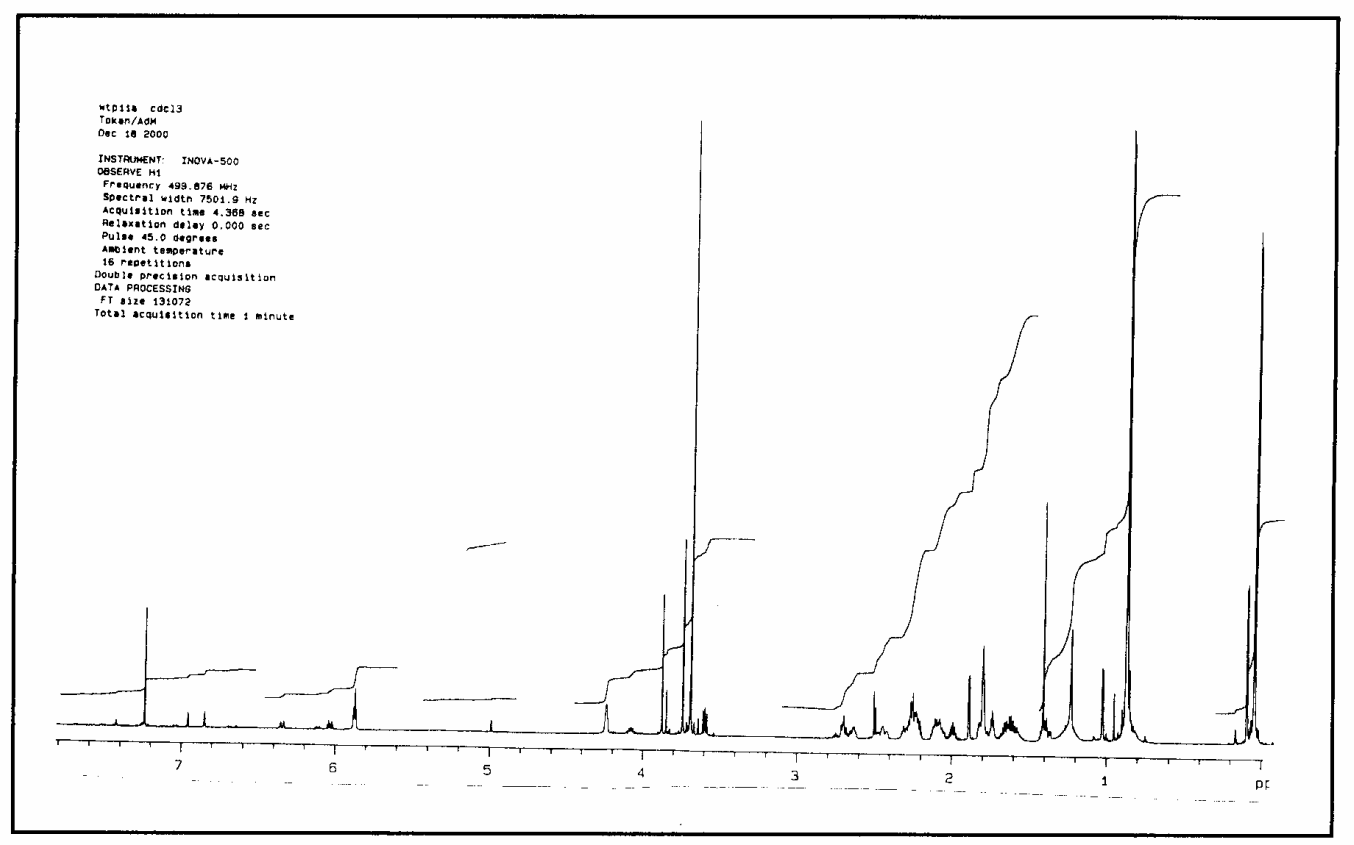

${ }^{1} H-N M R$ spectrum of methyl13-(tert-butyldimethylsilyloxy)tetracyclo[8.4.0.0 $\left.0^{1,3} \cdot 0^{4,9}\right]$ tetradeca-4,9-dien-3carboxyl-ate (122)

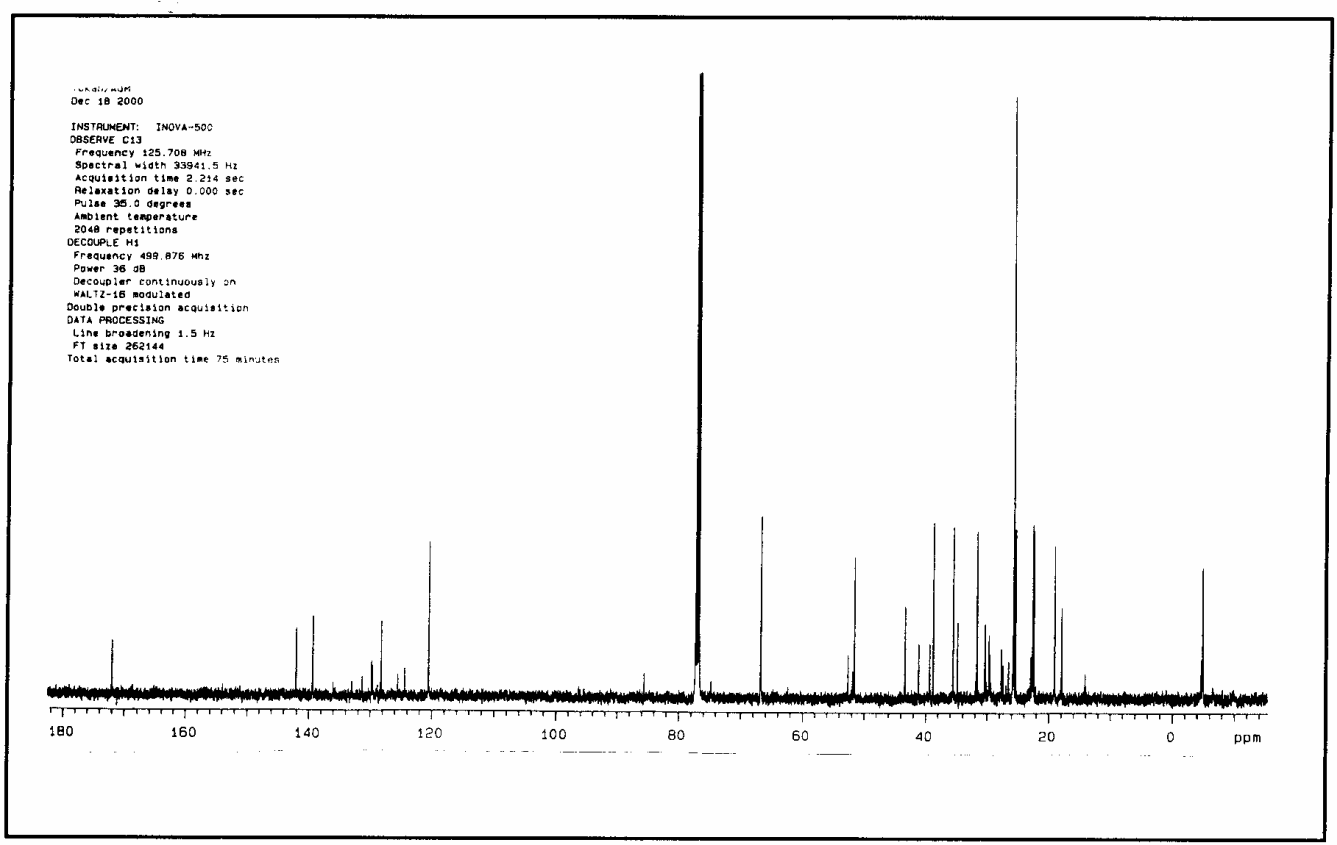

${ }^{13} \mathrm{C}-\mathrm{NMR}$ spectrum of methyl 13-(tert-butyldimethylsilyloxy)tetracyclo[8.4.0.0 $\left.0^{1,3} \cdot 0^{4,9}\right]$ tetradeca-4,9-dien-3carboxyl-ate (122) 


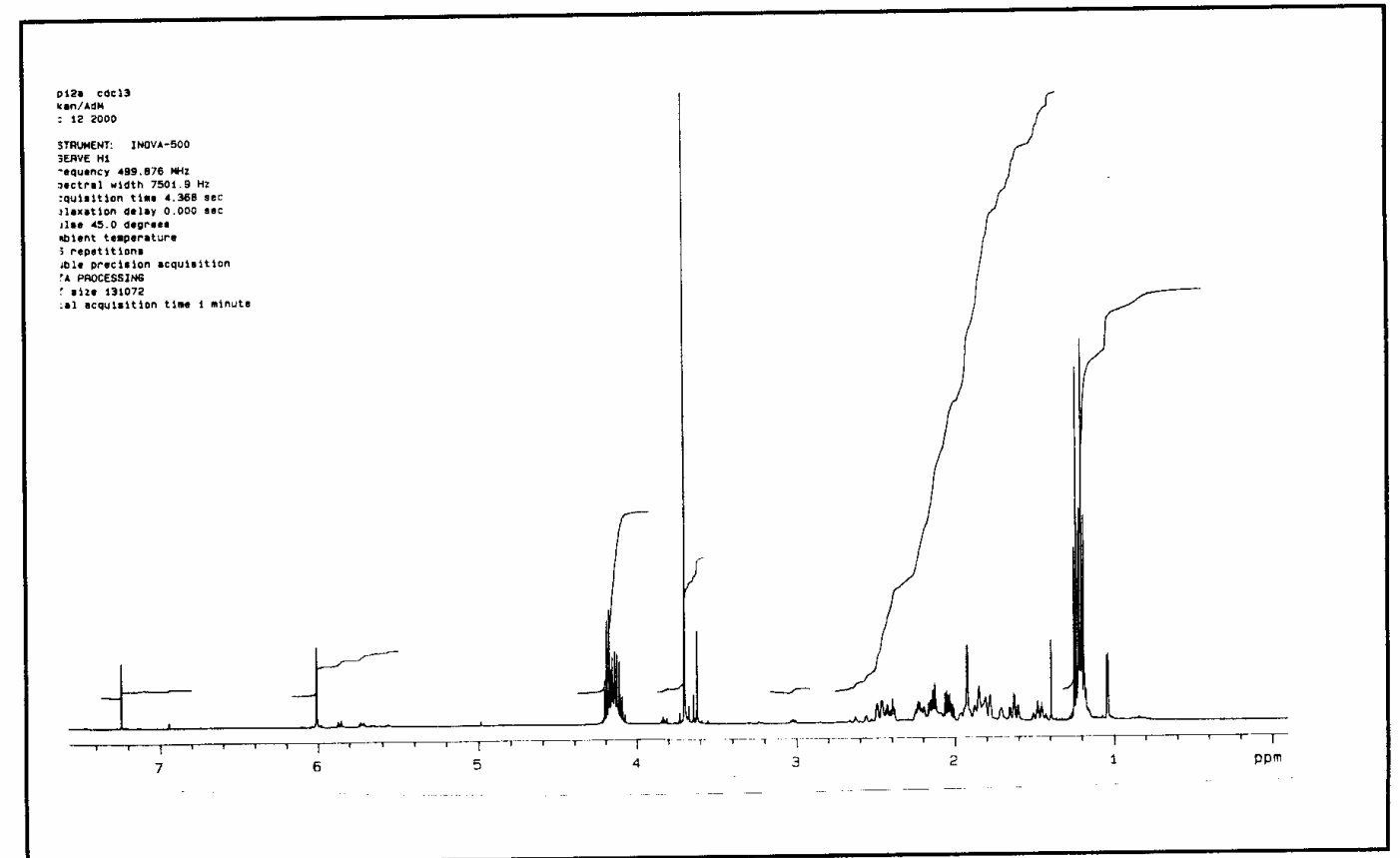

${ }^{1} H$-NMR spectrum of 6,6-diethyl 3-methyl tetracyclo[8.4.0.0 $\left.0^{1,3} \cdot 0^{4,9}\right]$ tetradeca-4,9-diene3,6,6-tricarboxylate (119-COOEt)

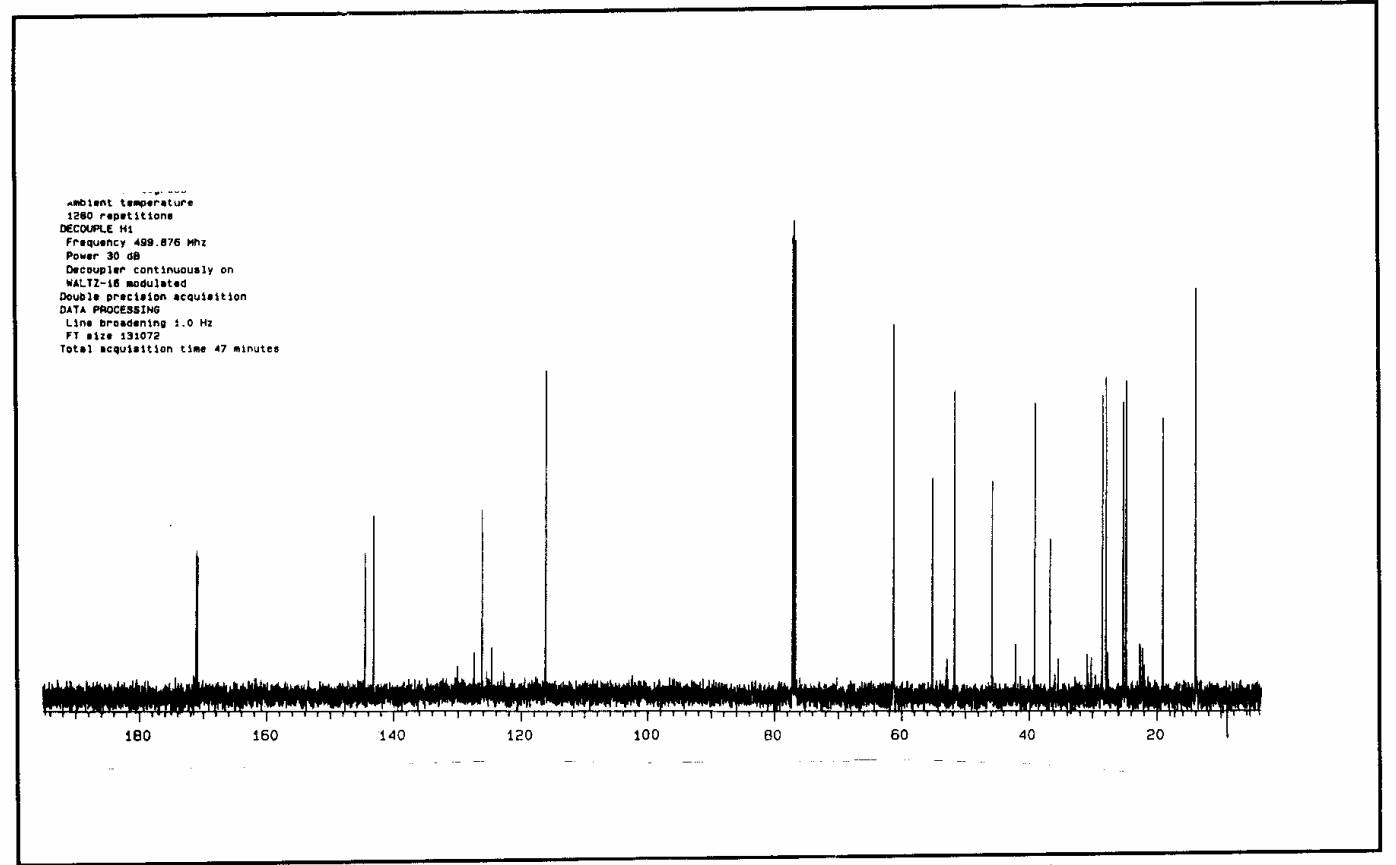

${ }^{13} \mathrm{C}-\mathrm{NMR}$ spectrum of 6,6-diethyl 3-methyl tetracyclo[8.4.0.0 $\left.0^{1,3} \cdot 0^{4,9}\right]$ tetradeca-4,9-diene3,6,6-tricarboxylate (119-COOEt) 


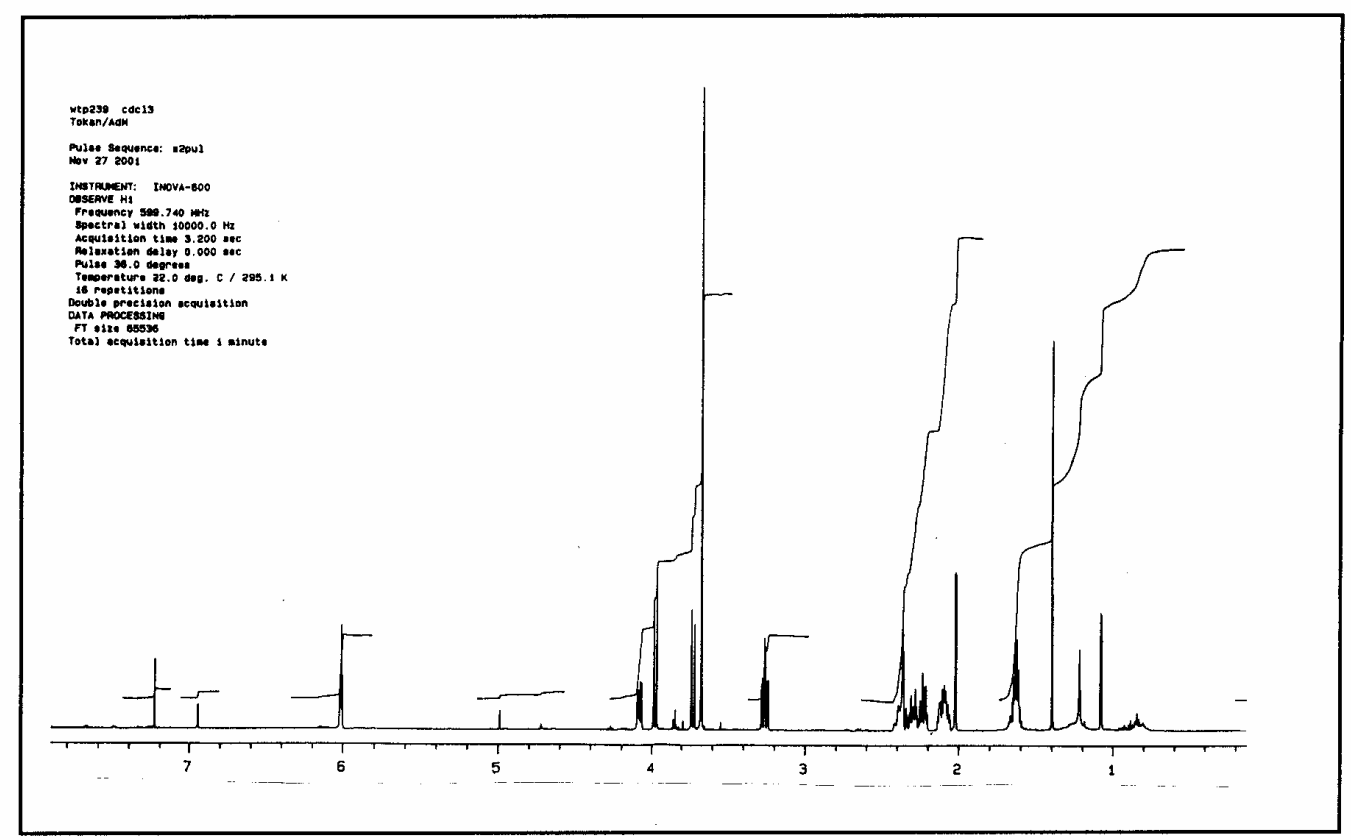

${ }^{1} H$-NMR spectrum of methyl 1,5,5a,7,8,9-hexahydro-2H-cyclopropa[2,3]indeno[2,1clpyran-5a-carboxylate (134)

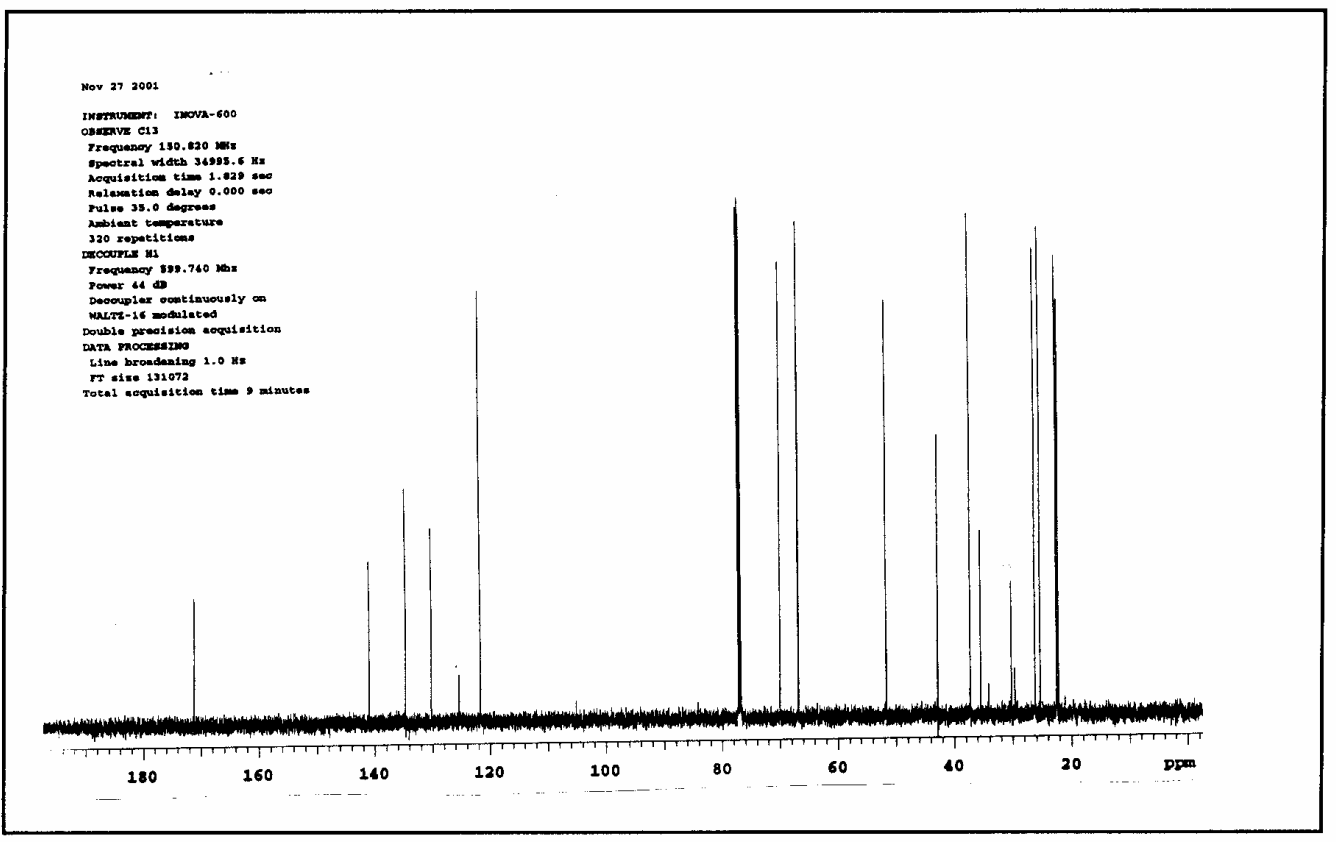

${ }^{13} \mathrm{C}-\mathrm{NMR}$ spectrum of methyl 1,5,5a,7,8,9-hexahydro-2H-cyclopropa[2,3]indeno[2,1cJpyran-5a-carboxylate (134) 


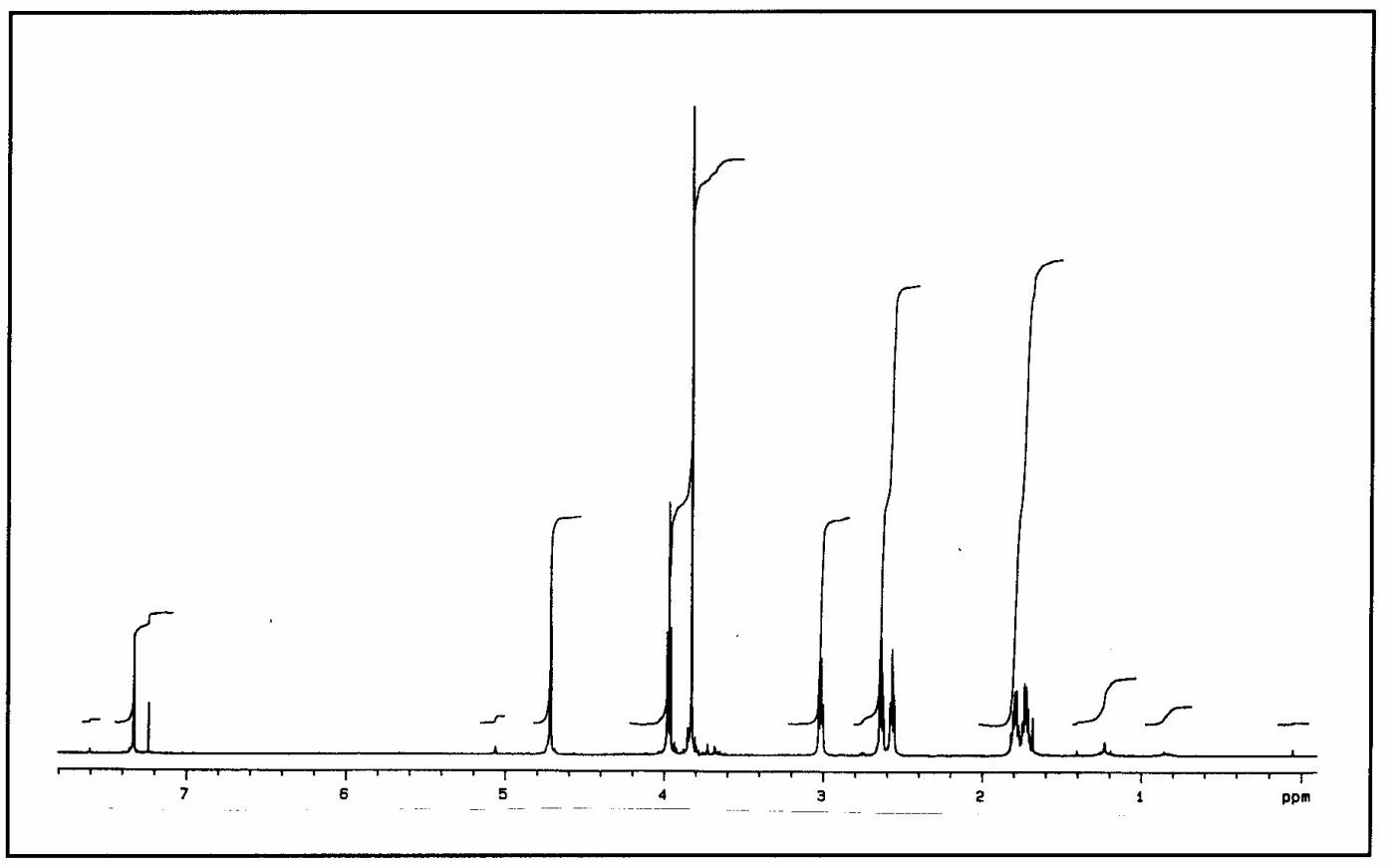

${ }^{1} H$-NMR spectrum of methyl 1,4,7,8,9,10-hexahydro-2H-benzo[f]isochromene-6carboxylate (135)

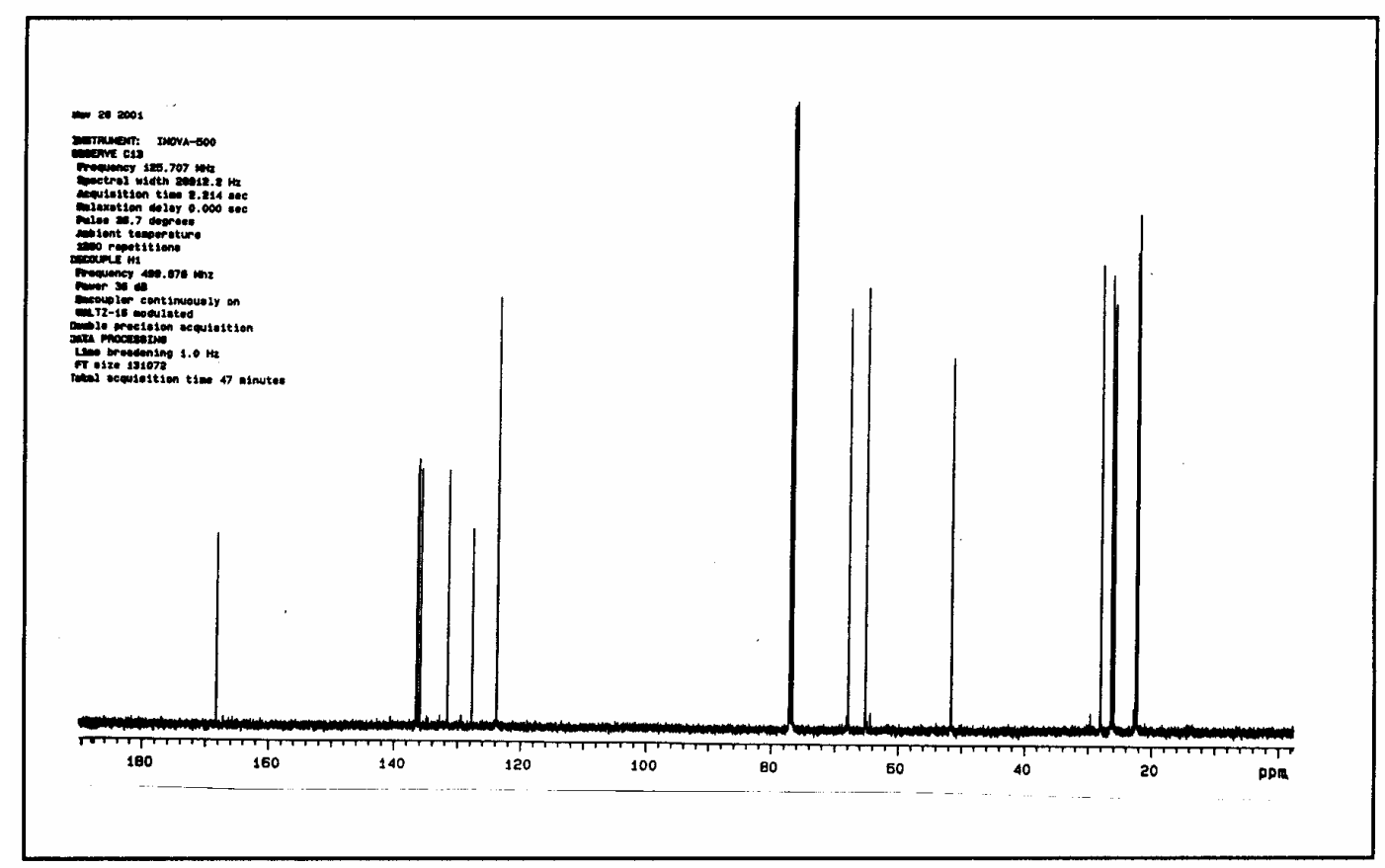

${ }^{13} \mathrm{C}$-NMR spectrum of Methyl 1,4,7,8,9,10-hexahydro-2H-benzo[f]isochromene-6carboxylate (135) 
128

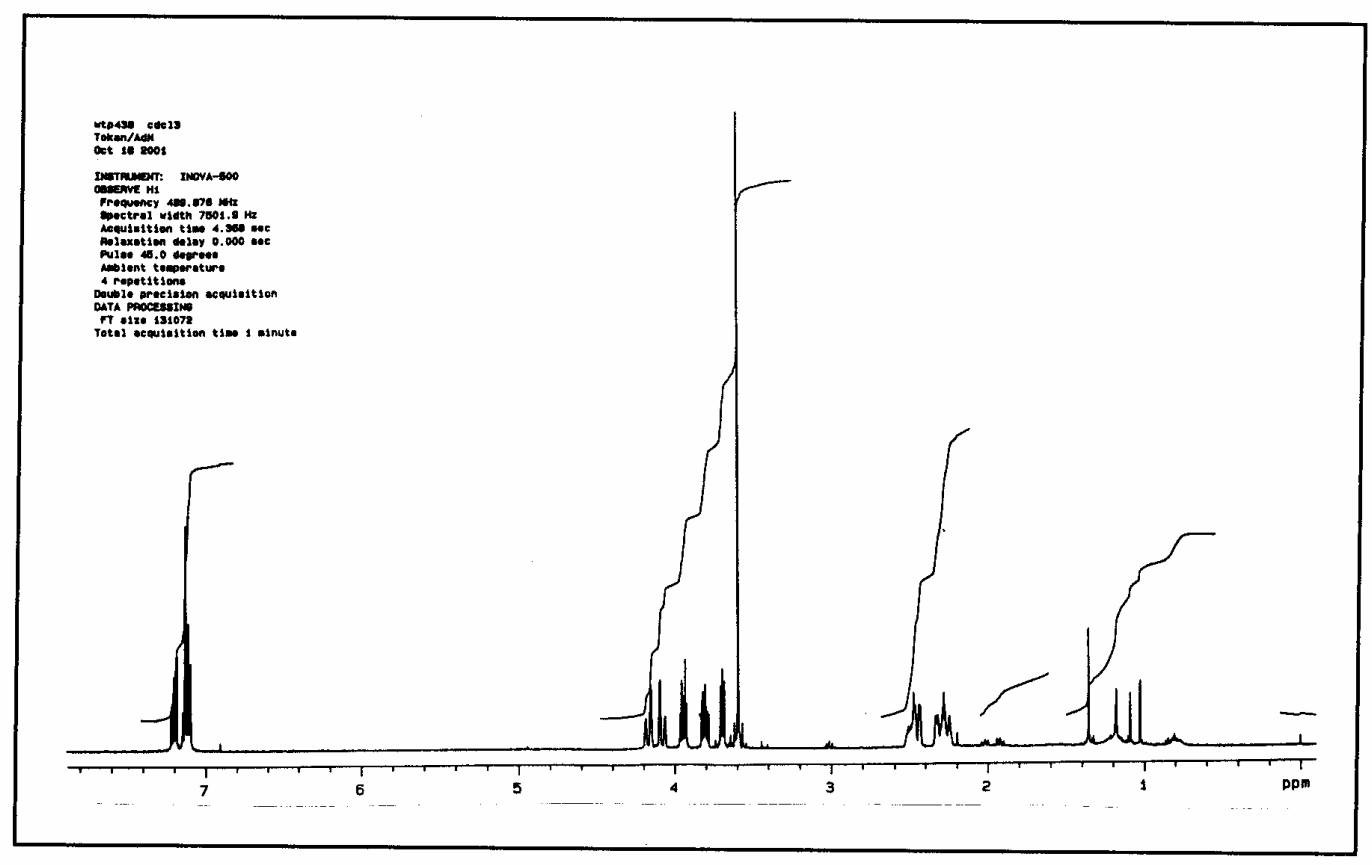

- ${ }^{1} H$-NMR spectrum of methyl 1,4,5,6-tetrahydro-2H-benzo[f]isochromene-6-carboxylate (136)

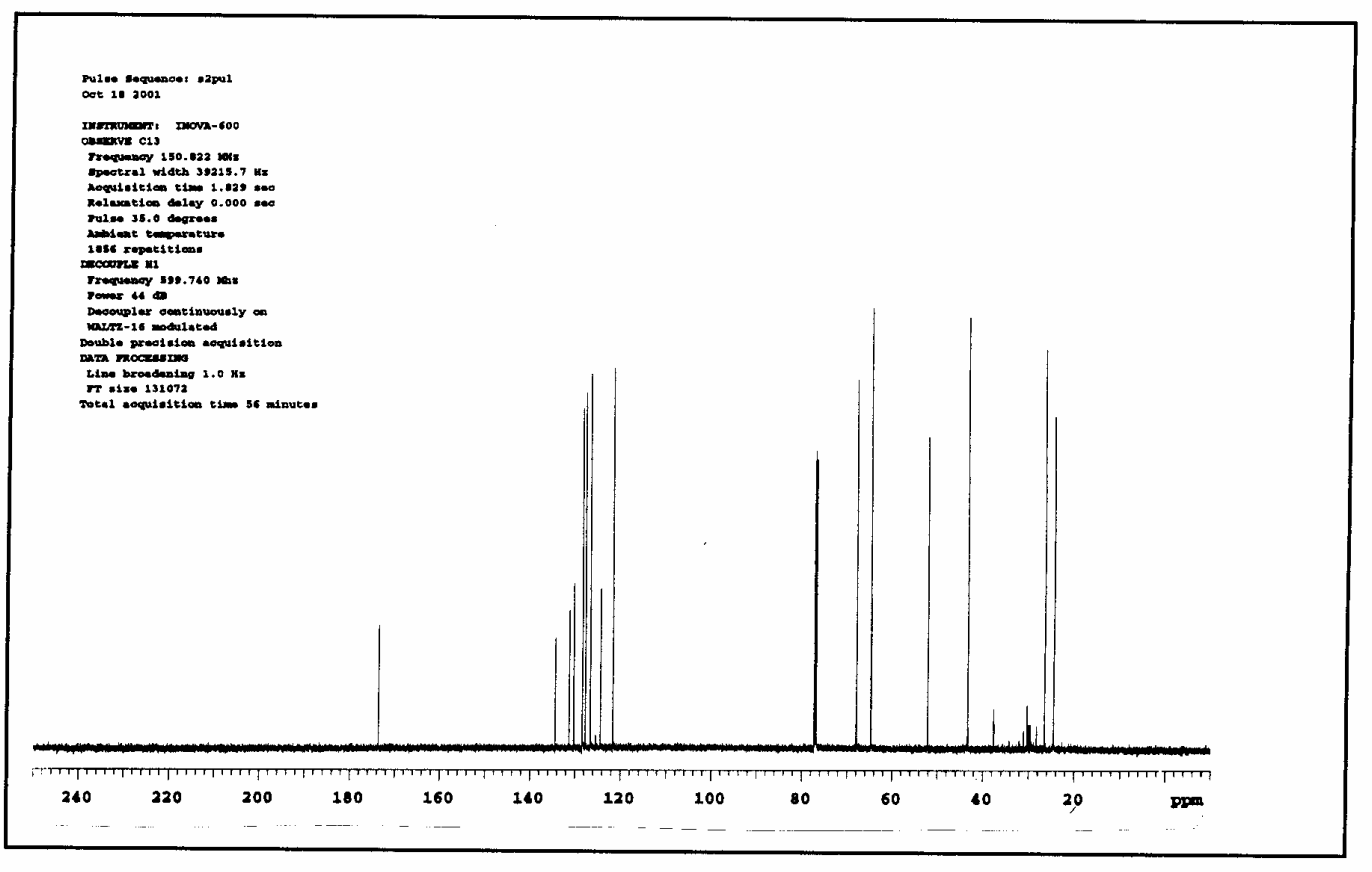

${ }^{13} \mathrm{C}-\mathrm{NMR}$ spectrum of methyl 1,4,5,6-tetrahydro-2H-benzolffisochromene-6carboxylate (136) 


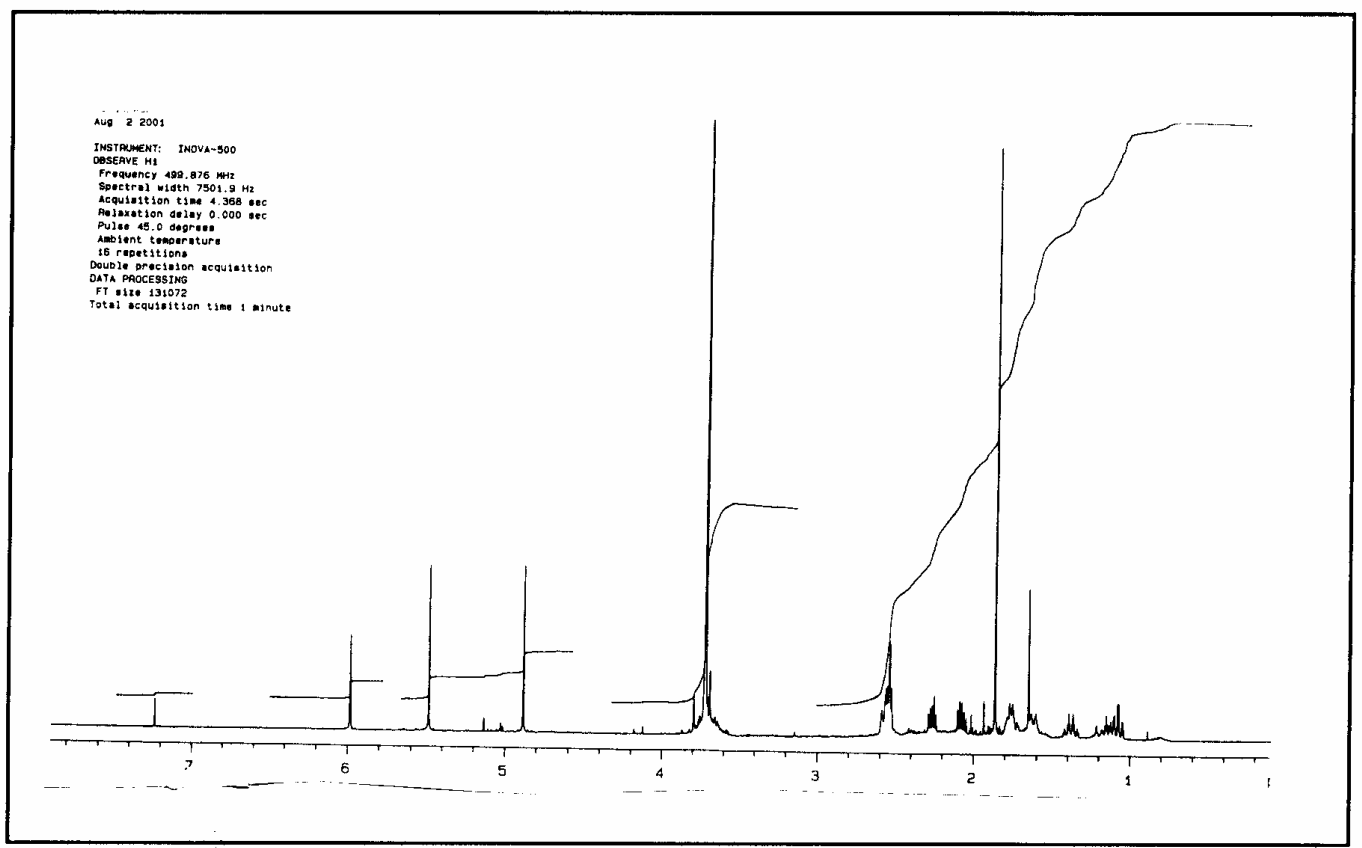

${ }^{1}$ H-NMR spectrum of dimethyl 9-acetyl-8-methylenetricyclo[7.4.0.0 $\left.0^{2,7}\right]$ trideca-1, 6-diene5,5-dicarboxylate (146)

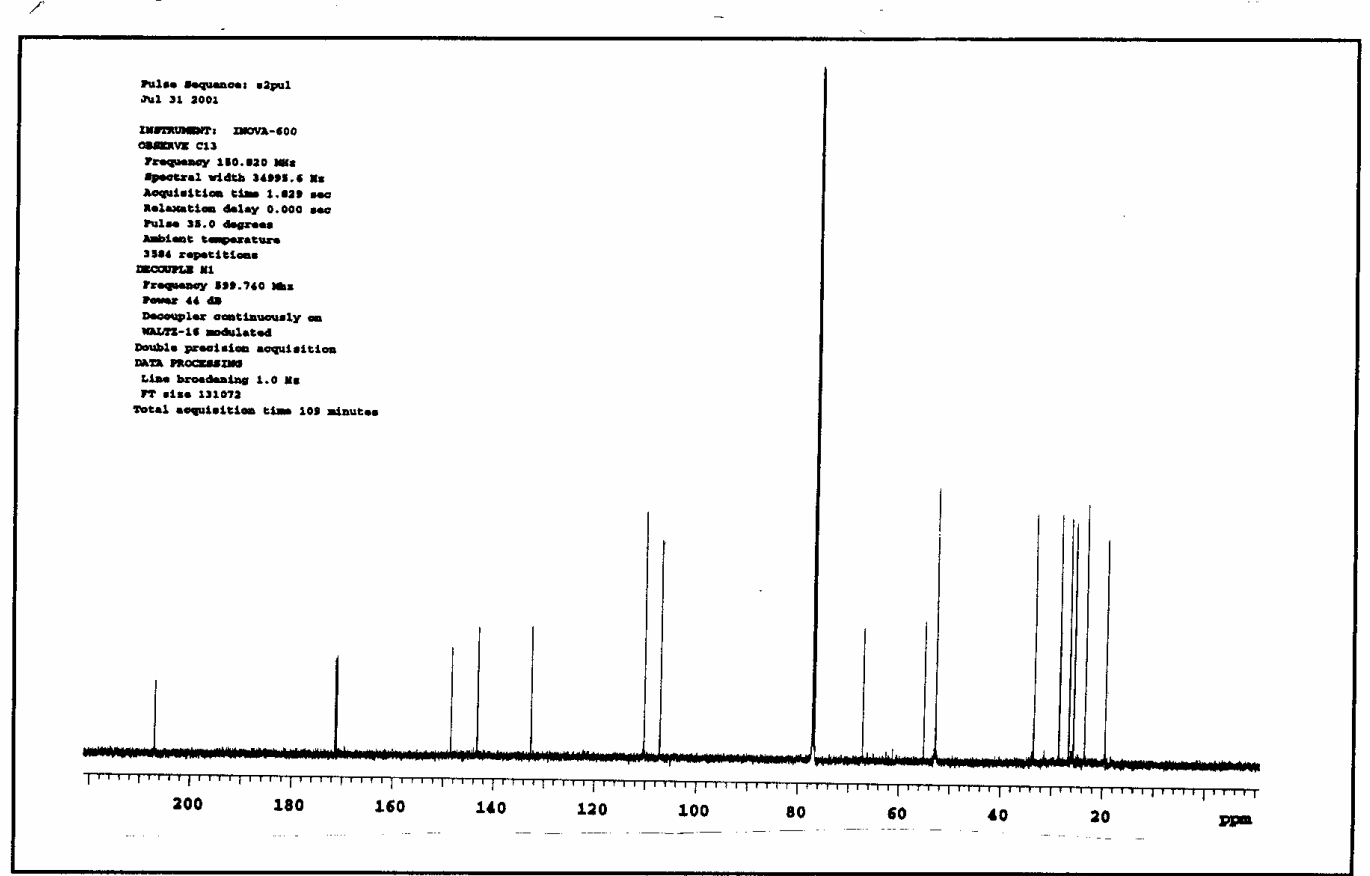

${ }^{13} \mathrm{C}-\mathrm{NMR}$ spectrum of dimethyl 9-acetyl-8-methylenetricyclo $\left[7.4 .0 .0^{2,7}\right]$ trideca-1,6-diene5,5-dicarboxylate (146) 


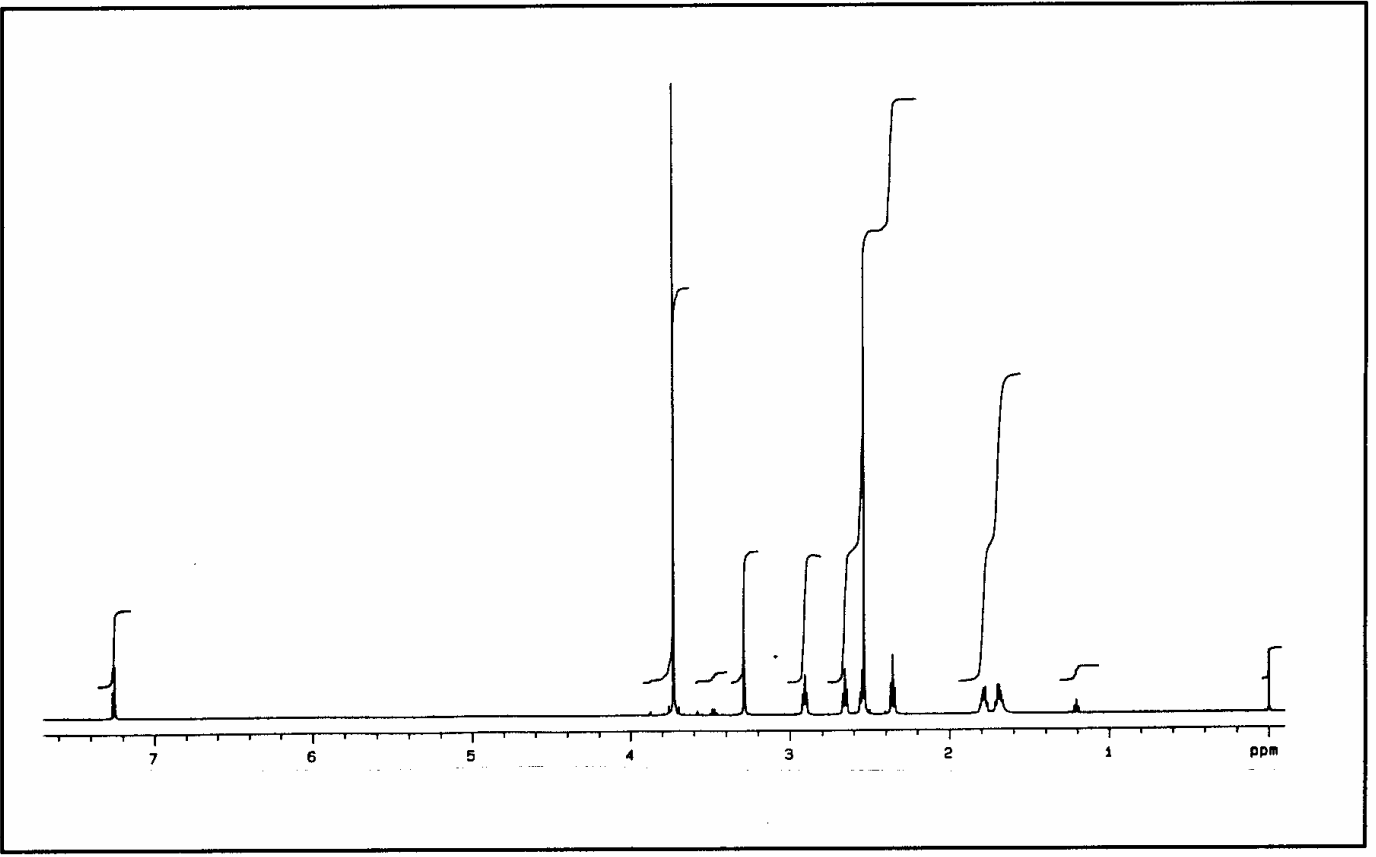

${ }^{1}$ H-NMR spectrum of dimethyl 9-acetyltricyclo[8.4.0.0 $0^{2,7}$ tetradeca-1(10),2(7),8-triene5,5-dicarboxylat (147).

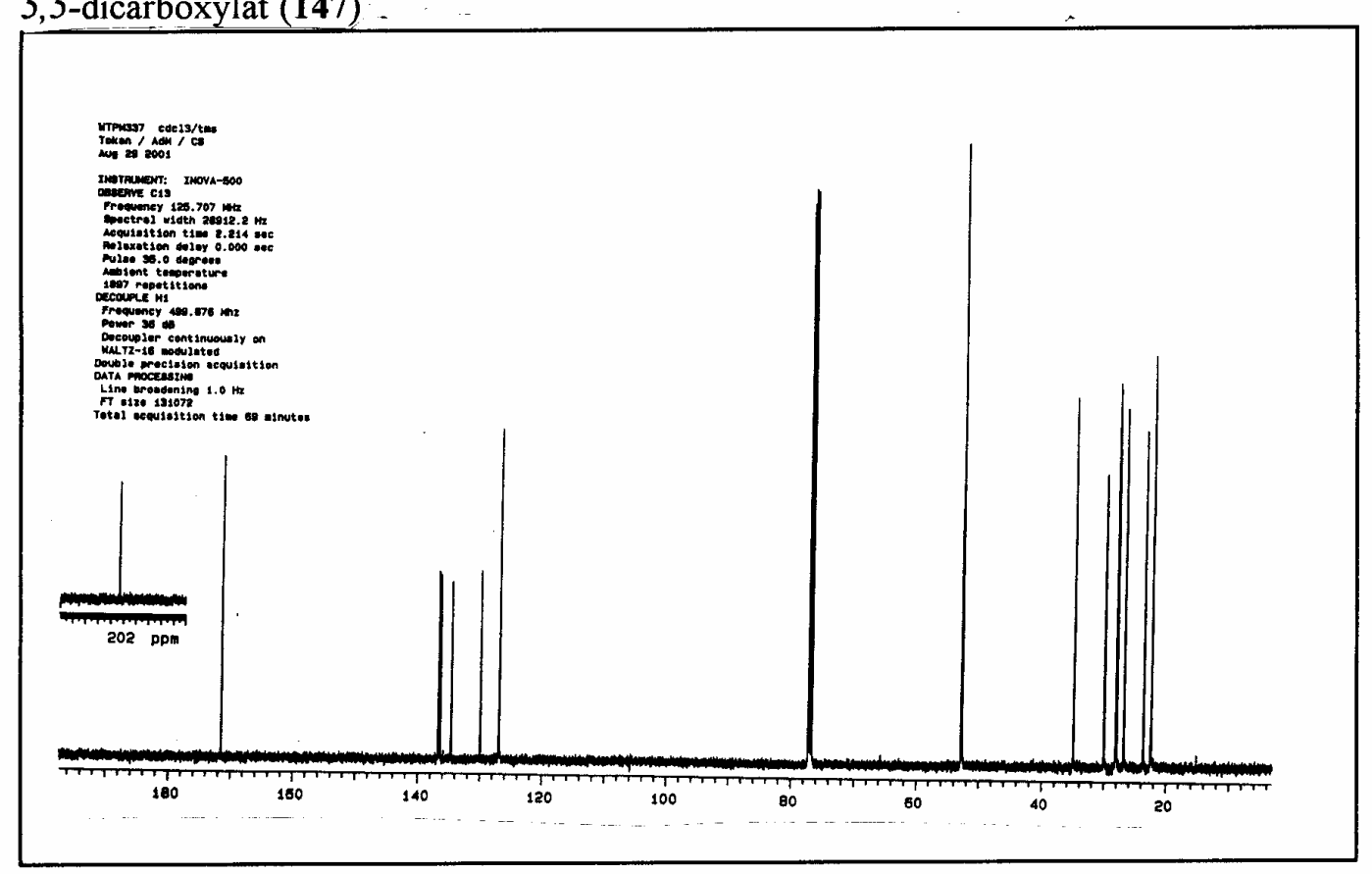

${ }^{13} \mathrm{C}$-NMR spectrum of dimethyl 9-acetyltricyclo[8.4.0.0 $\left.0^{2,7}\right]$ tetradeca-1(10),2(7),8-triene5,5-dicarboxylat (147) 


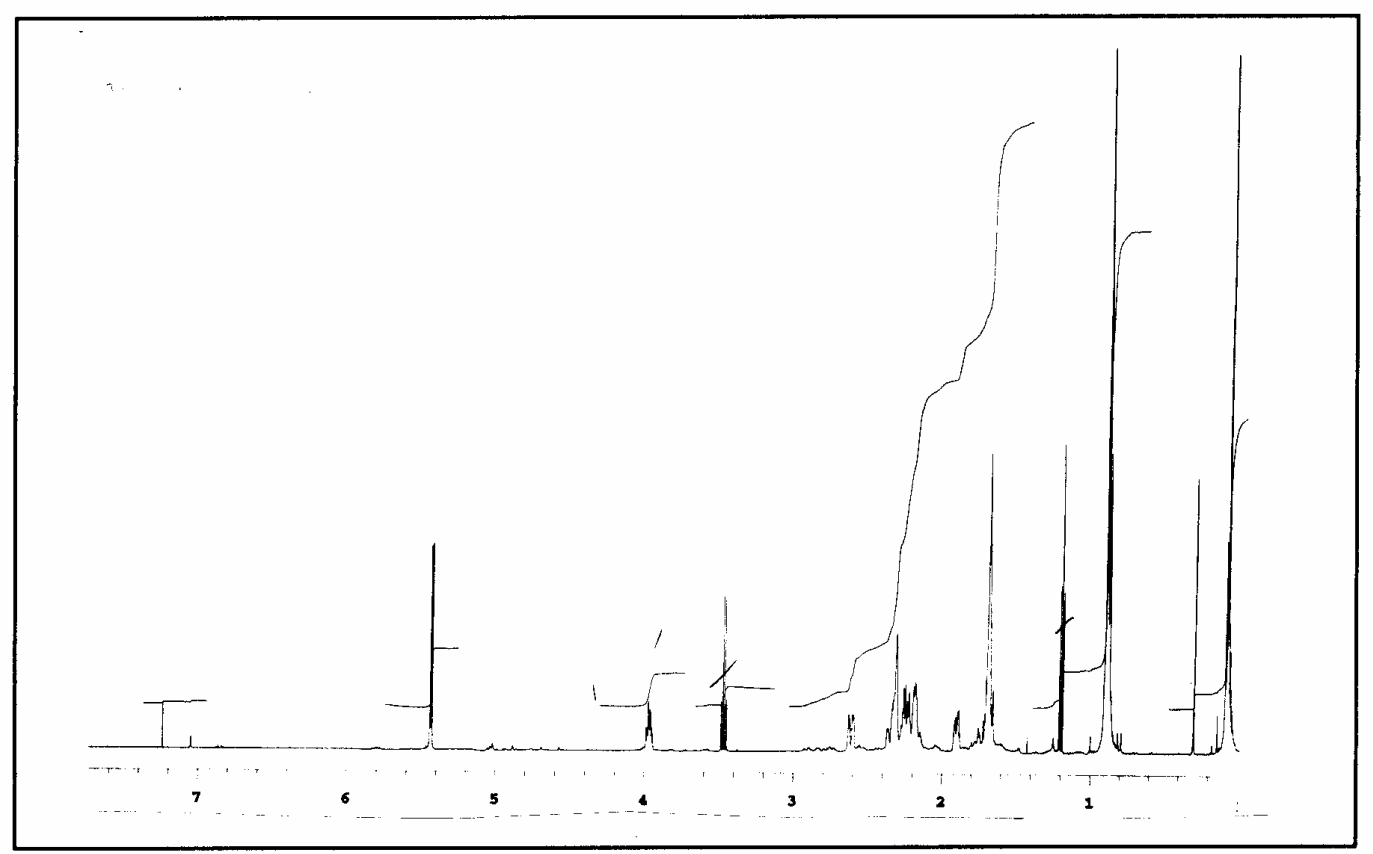

${ }^{1} H-N M R$ spectrum of

5-(tert-butyldimethylsilyloxy)-8-methylenetricyclo[7.4.0.0 $0^{2,7}$ |trideca-1(9),2(7)-diene(166)

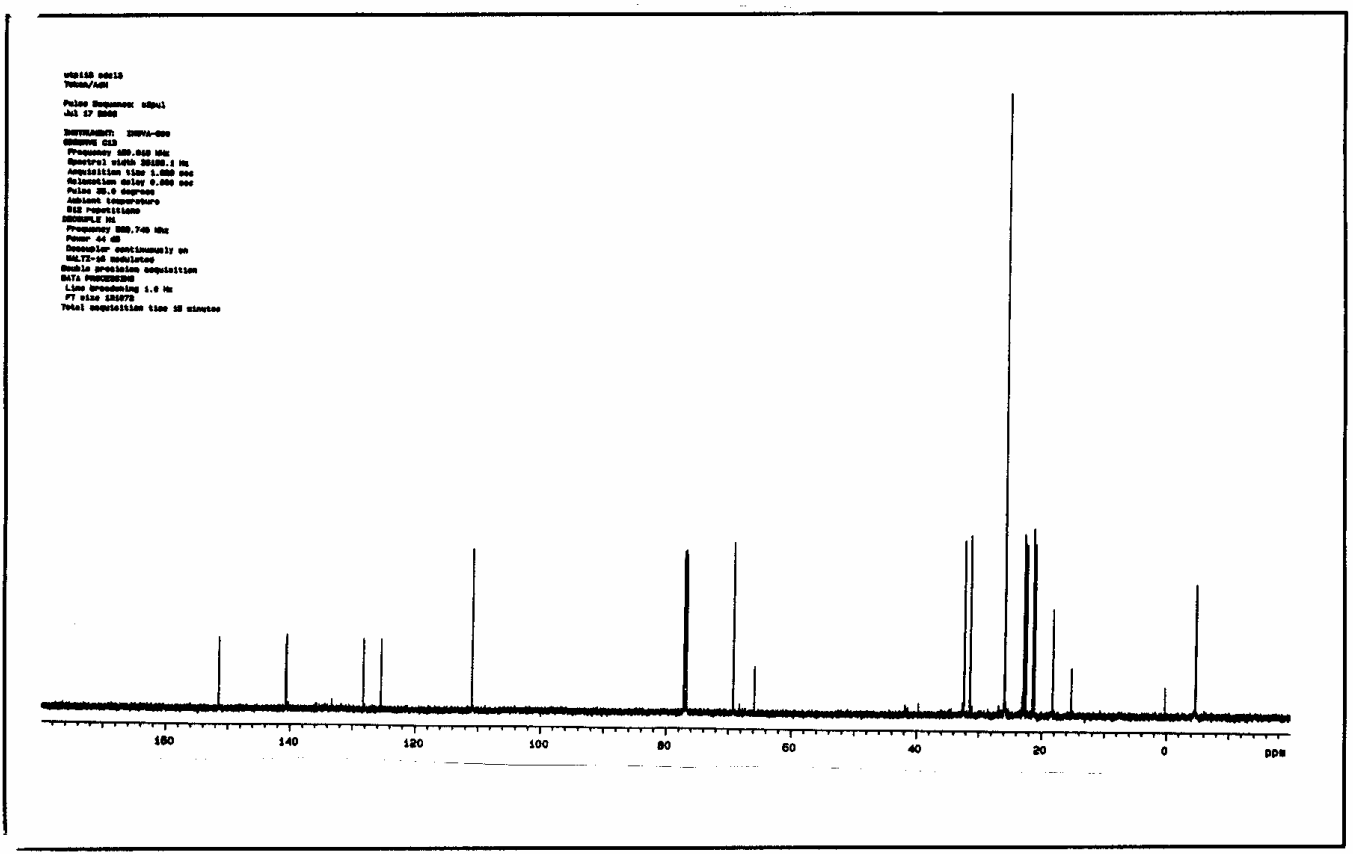

${ }^{T_{3}} \mathrm{C}-\mathrm{NMR}$ spectrum of

5-(tert-butyldimethylsilyloxy)-8-methylenetricyclo[7.4.0.0 $\left.0^{2,7}\right]$ trideca-1(9),2(7)-diene(166) 


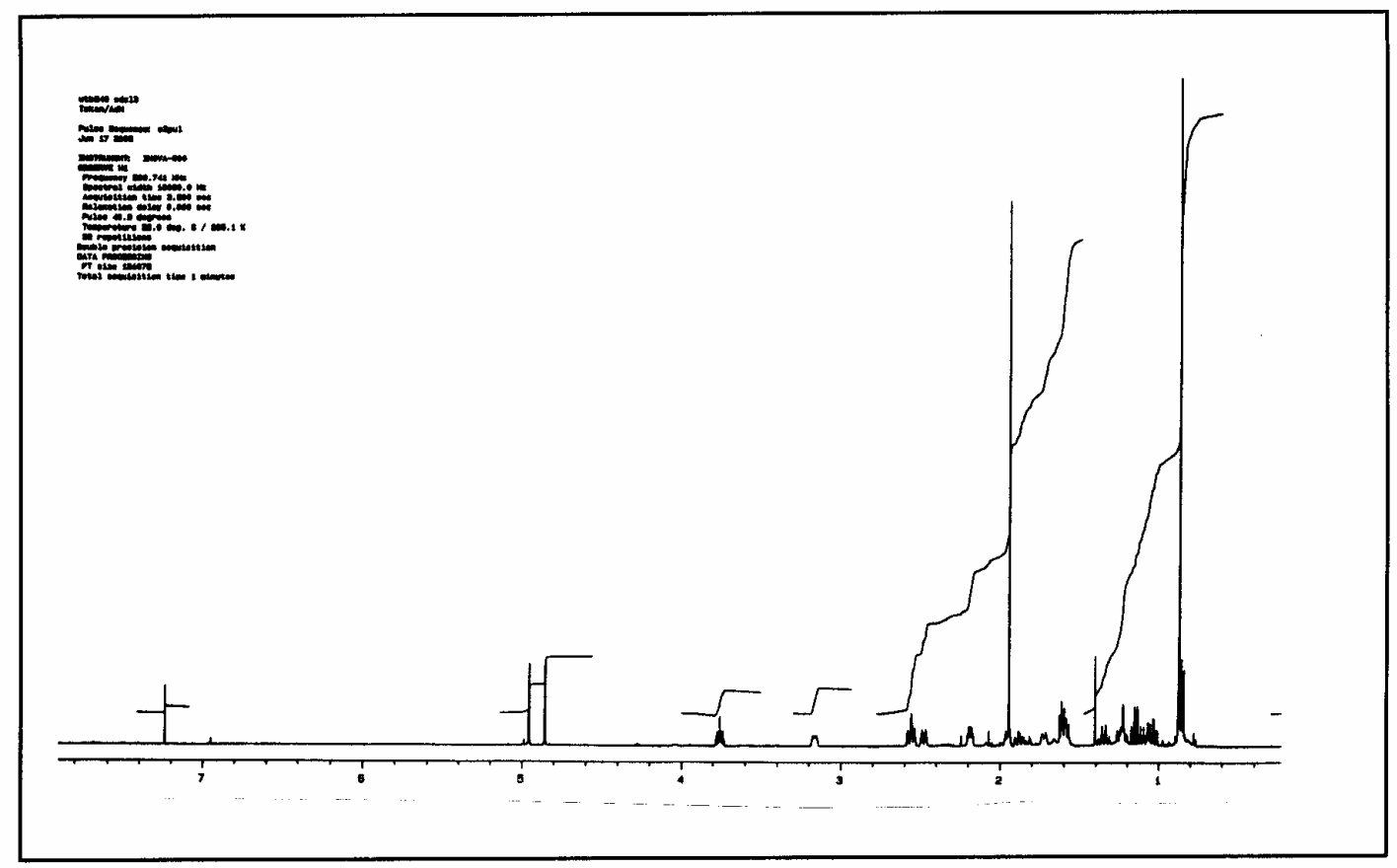

${ }^{1} H-N M R$ spectrum of I-[(7'R,9'S,11'S)-8'-methylene-11'-(tert-butyldimethylsilyloxy) tricyclo[7.4.0.0 $\left.0^{2,7}\right]$ tridecl'-en-7'-yl]-lethanone (155)

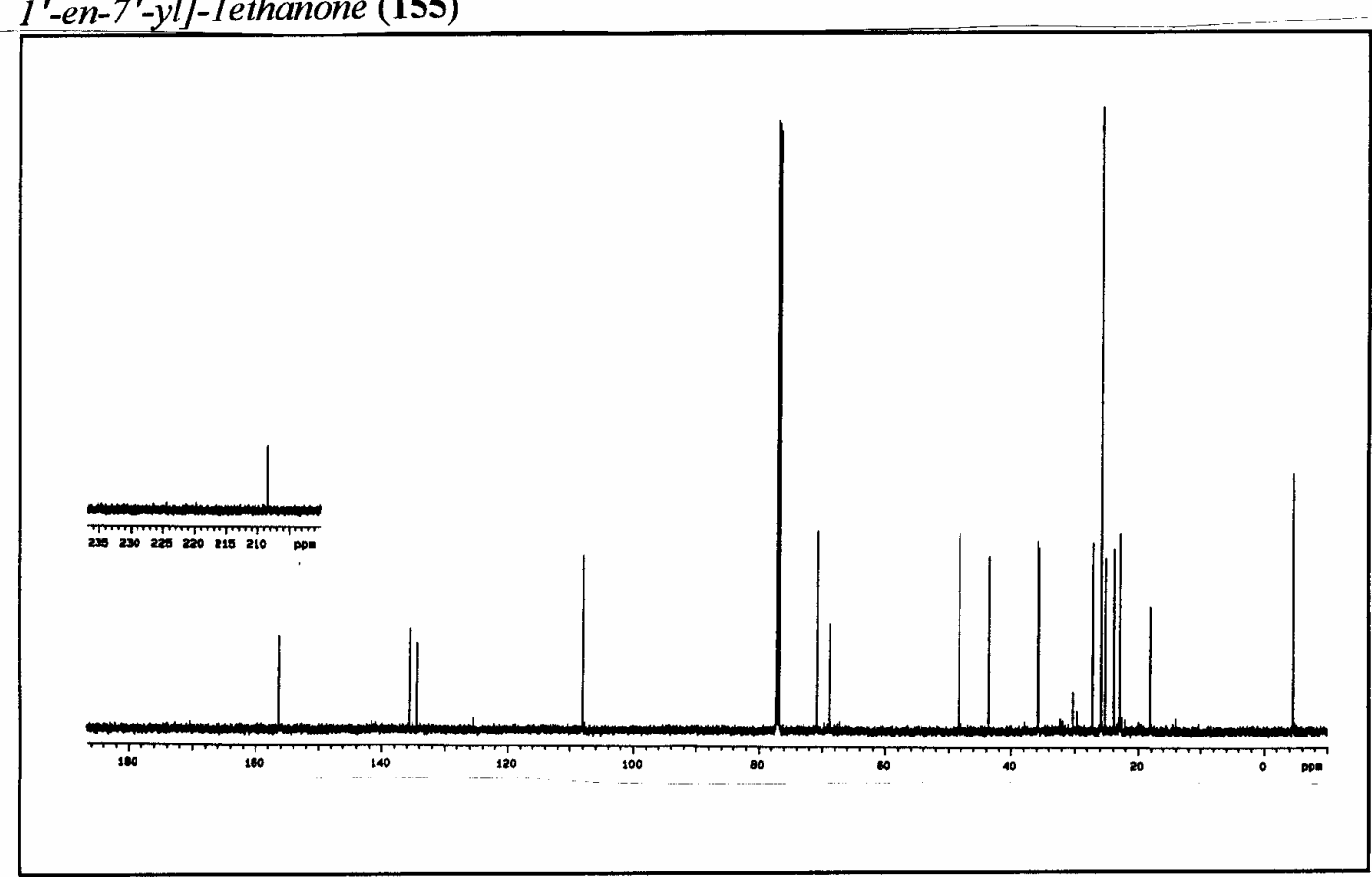

${ }^{13} \mathrm{C}-\mathrm{NMR}$ spectrum of

$1-\left[\left(7^{\prime} R, 9^{\prime} S, 11^{\prime} S\right)-8^{\prime}-\right.$ methylene-11'-(tert-butyldimethylsilyloxy)tricyclo[7.4.0.0 $\left.0^{2 ; 7}\right] \mathrm{Jtridec}$ I'-en-7'-yl]-lethanone (155) 


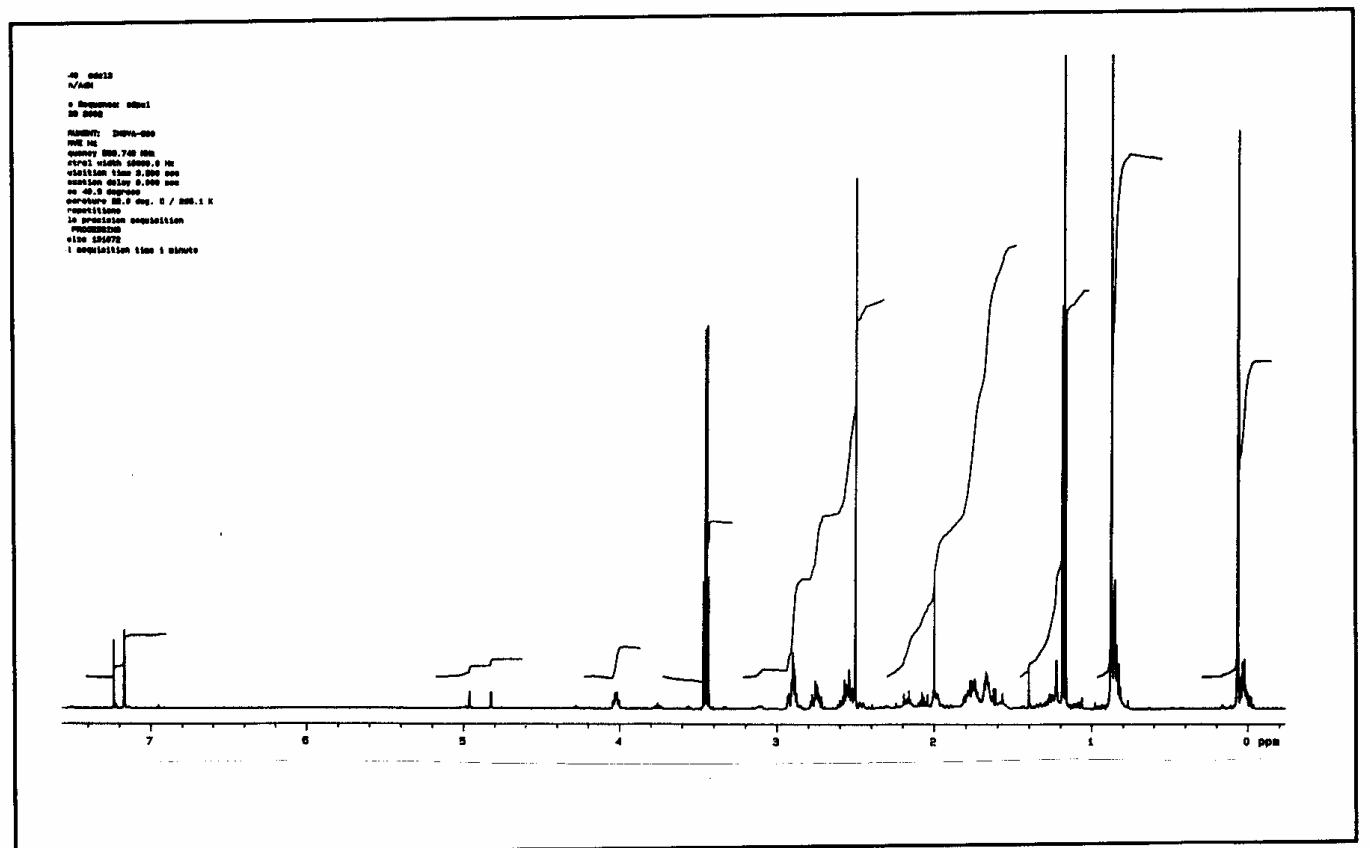

${ }^{1} H$-NMR spectrum of 1-[12'-(tert-butyldimethylsilyloxy)tricyclo[8.4.0.0 $\left.0^{2 ;}{ }^{\prime}\right]$ tetradeca$I^{\prime}\left(10^{\prime}\right), 2^{\prime}\left(7^{\prime}\right), 8^{\prime}$-trien-8'-yl]-I-ethanone (158)

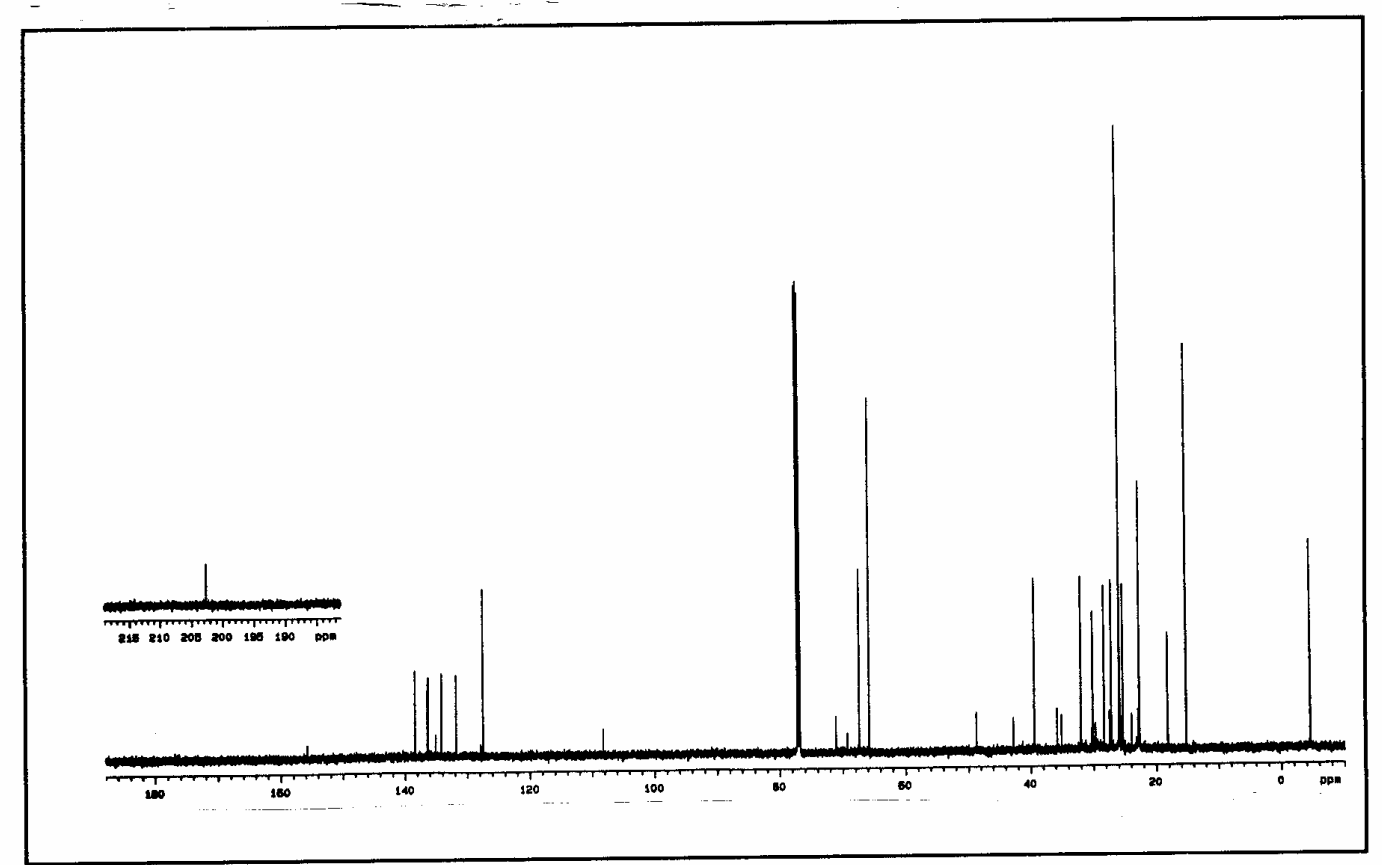

${ }^{13} \mathrm{C}-N M R$ spectrum of $1-\left[12^{\prime}-\left(\right.\right.$ tert-butyldimethylsilyloxy)tricyclo[8.4.0.0 $\left.0^{2,7}\right]$ tetradeca$I^{\prime}\left(10^{\prime}\right), 2^{\prime}\left(7^{\prime}\right), 8^{\prime}$-trien-8'-yl]-1-ethanone (158) 


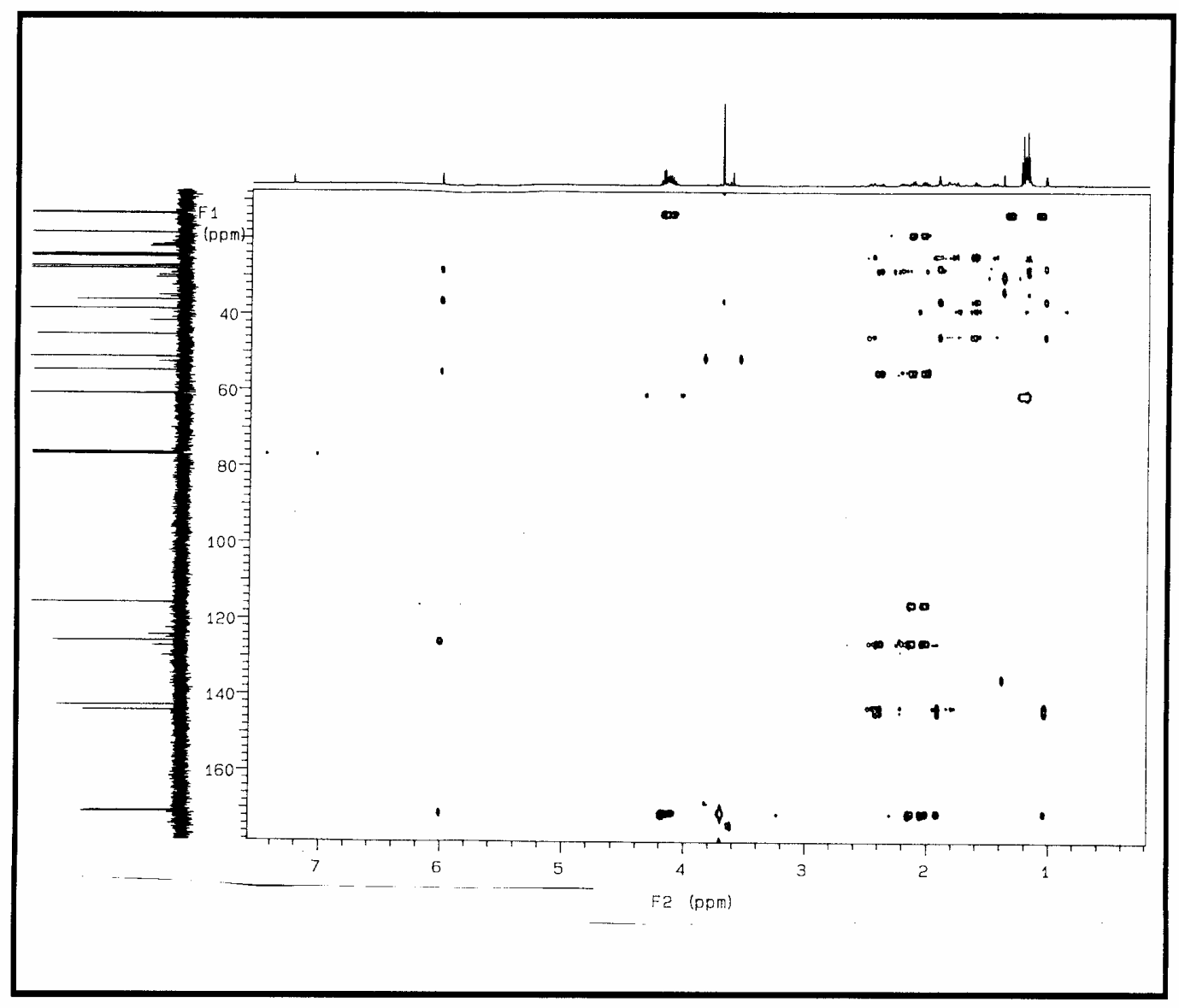

HMBC spectrum of 6,6-diethyl 3-methyl tetracyclo[8.4.0.0 $\left.0^{1,3} \cdot 0^{4,9}\right]$ tetradeca-4,9-diene3,6,6-tricarboxylate (119-COOEt) 


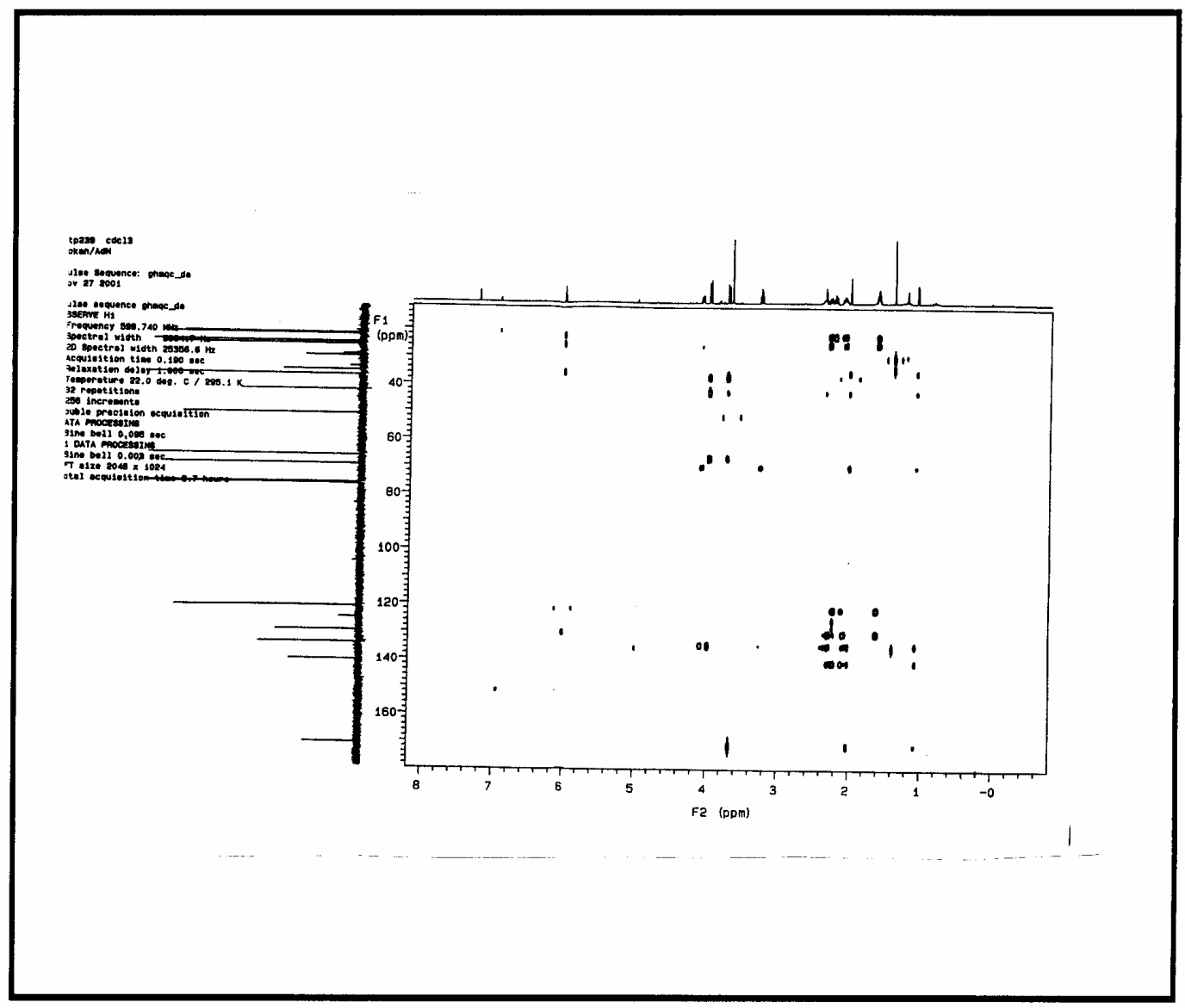

HMBC spectrum of methyl 1,5,5a,7,8,9-hexahydro-2H-cyclopropa[2,3]indeno[2,1clpyran-5a-carboxylate (134) 


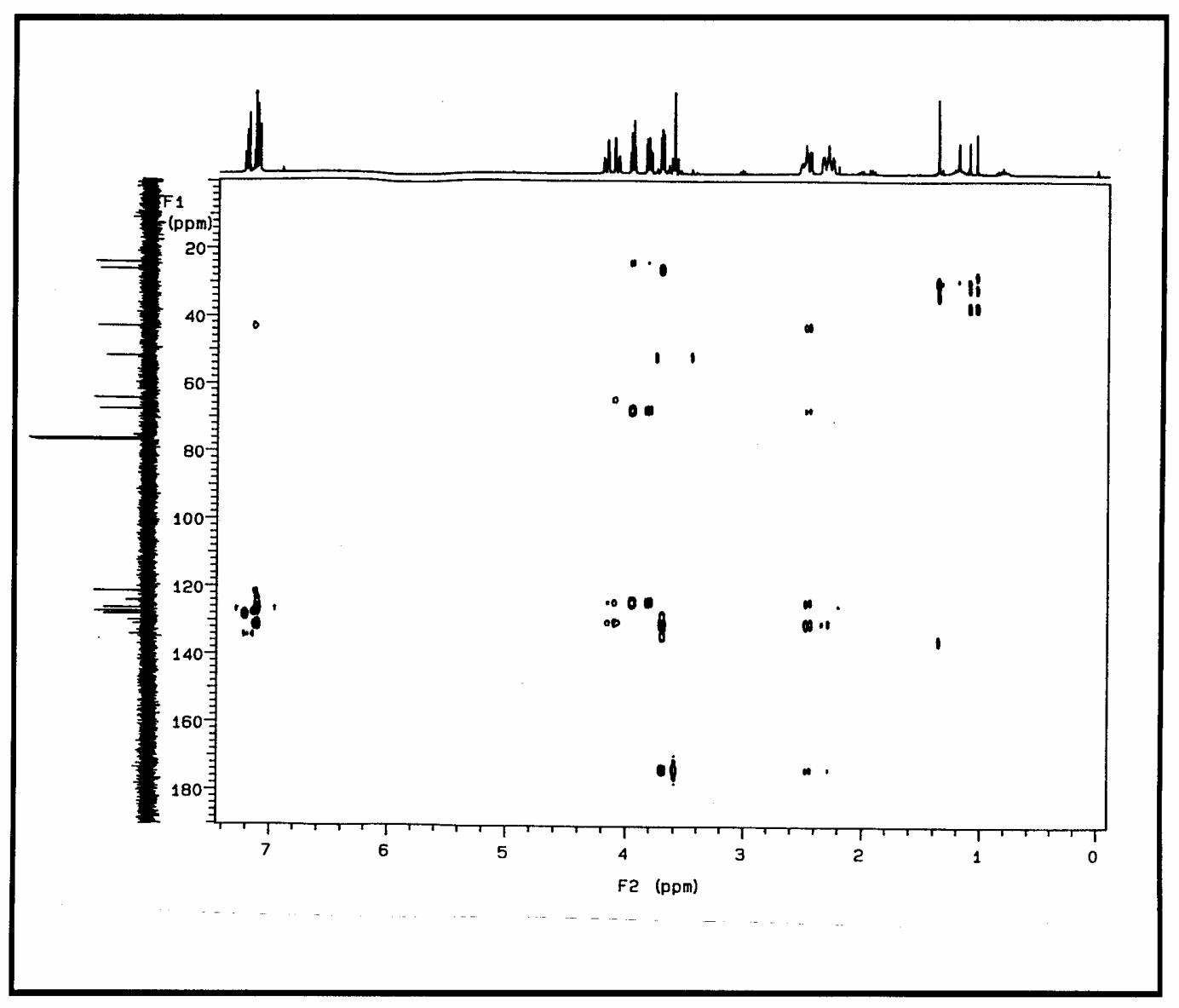

HMBC spectrum of methyl 1,4,5,6-tetrahydro-2H-benzo[f]isochromene-6-carboxylate (136) 


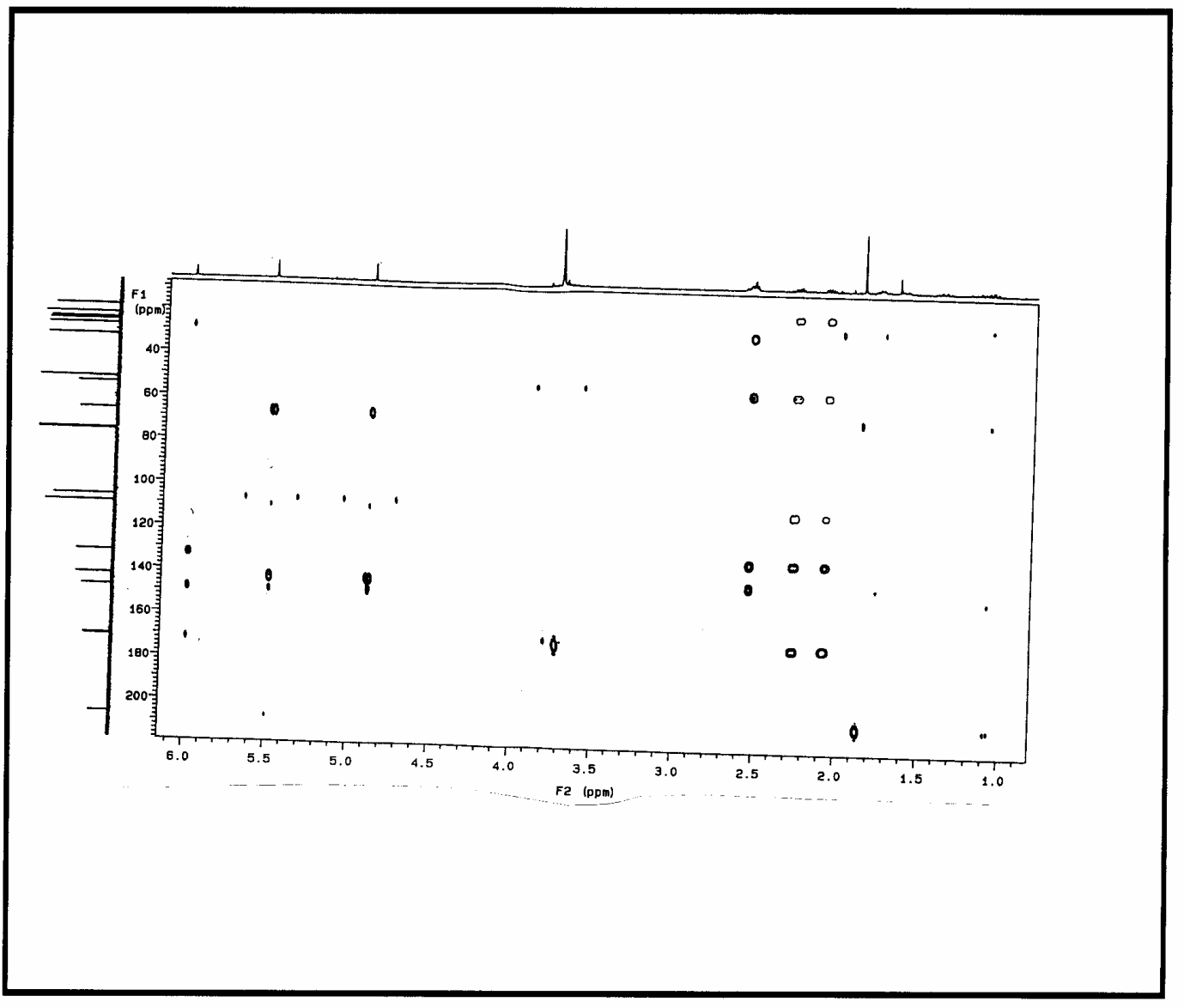

HMBC spectrum of dimethyl 9-acetyl-8-methylenetricyclo[7.4.0.0 $\left.0^{2,7}\right]$ trideca-1,6-diene5,5-dicarboxylate (146) 


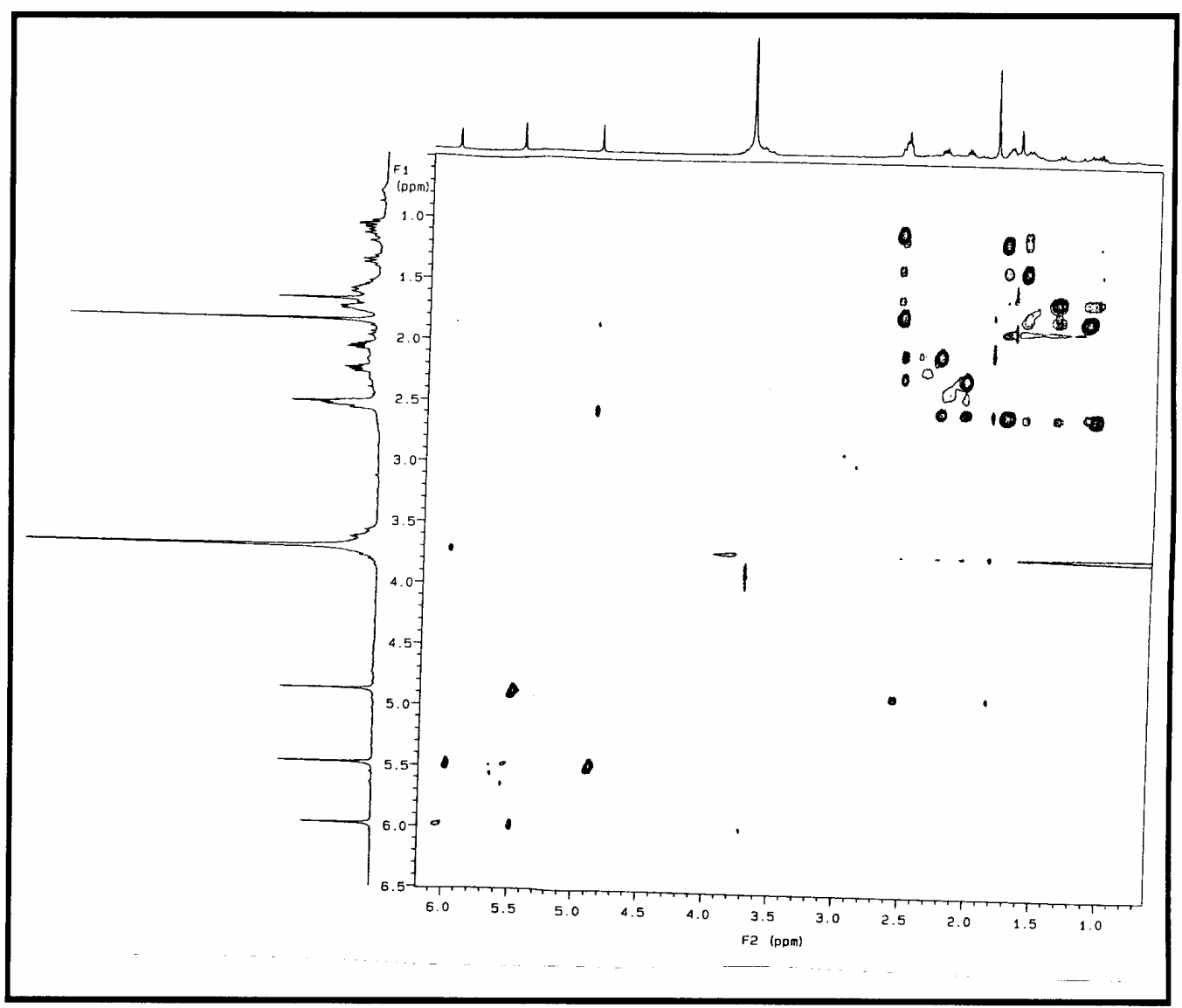

H/H NOESY spectrum of dimethyl 9-acetyl-8-methylenetricyclo[7.4.0.0 $\left.0^{2,7}\right]$ trideca-1,6diene-5,5-dicarboxylate (146) 


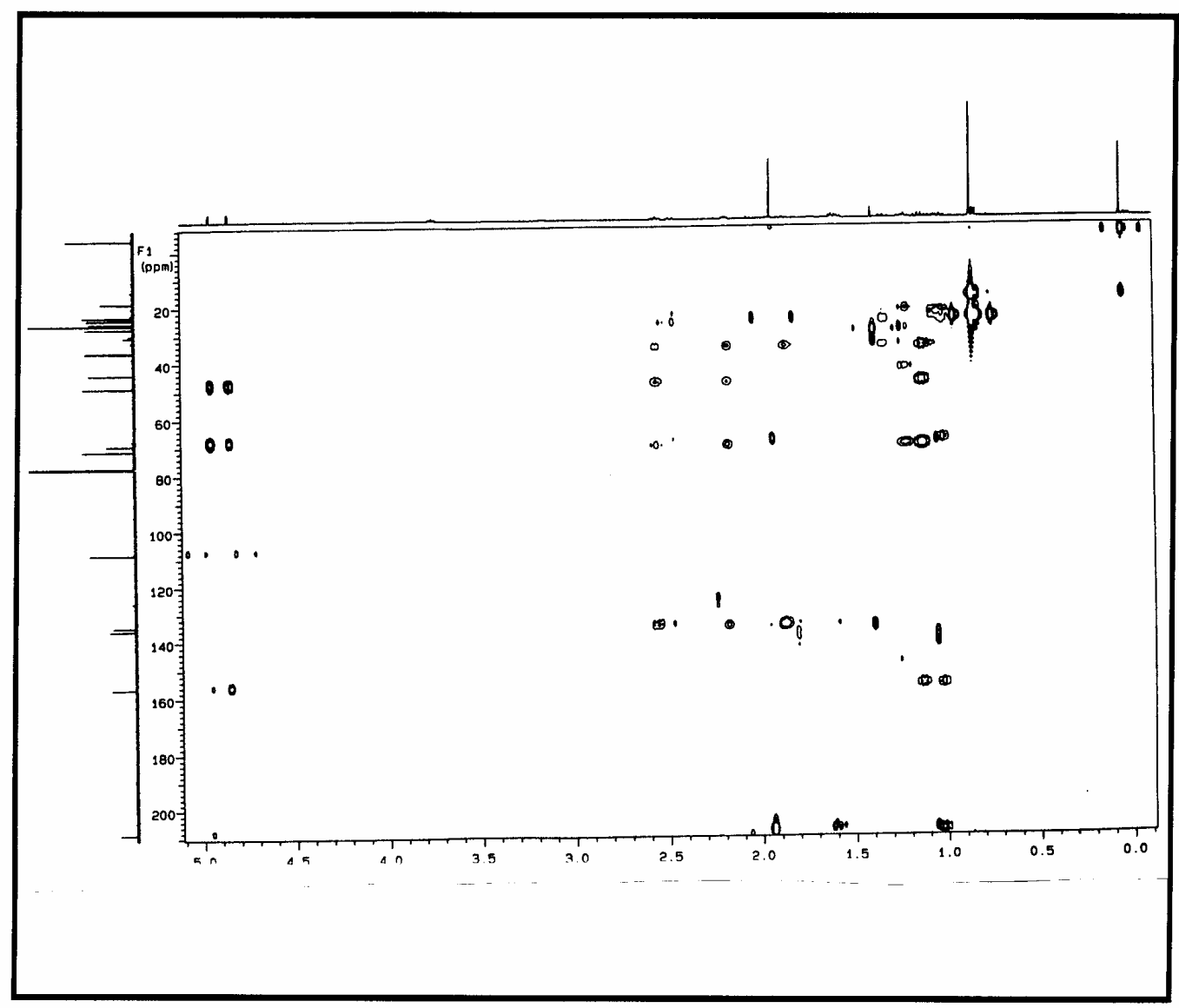

HMBC spectrum of

$1-\left[\left(7^{\prime} R, 9^{\prime} S, 1 I^{\prime} S\right)-8^{\prime}-\right.$ methylene-1I'-(tert-butyldimethylsilyloxy) tricyclo[7.4.0.0 $\left.0^{2 ; 7}\right]$ tridec-

I'-en-7'-yl]-1ethanone (155) 


\section{Acknowledgements}

I would like to express about my greatest gratitude for Prof. Dr. Armin de Meijere for giving me the opportunity to do this work in his group and under his supervision. I would also like to thank Prof. Dr. Axel Zeeck for interesting biochemistry course. My gratefulness also to Prof. Dr. Ulf Diederichsen and Prof. Dr. J. Magull.

My thanks also to Prof. Dr. Michael A. Kuznetsov and Dr. Victor Sokolov for sharing me their chemical knowledge.

I would like to thank those who without their contribution this work cannot be done. Therefore, I would like to thank Dr. H. Frauendorf and Ms. G. Udvarnoki for mass spectra. Thanks also to Mr. Machinek from NMR department and special thanks to Mrs. Carola Zolke for her meticulously NMR spectra and her patience during getting the NMR spectra. Thanks to Mr. Franck Hambloch for getting the elemental analysis.

Thanks to Mrs Langerfeldt and Mrs Kiel-Knepel for their precious assistance.

I am indebted to Dr. Andrei Savchenko for his continuous assistance and encouragement during my work on this thesis. Thanks also to Mr. "James" Wu for the interesting and fruitful discussions in chemistry. I would like to thank my colleague with whom I shared the lab and spent the time during preparation of this thesis Mr. R. Scheurich.

Thanks to Mr. Michael Schelper for supplying me with computer programs necessary for writing this thesis, and for proof reading of my thesis. 


\section{Lebenslauf}

Ich wurde am 16.9.1968 als Sohn von Mohammad Tokan und seiner Frau Wijdan Mohyar in Amman in Jordanien geboren. Von 1972 bis 1985 besuchte ich das „Islamic Scientific College“ in Amman. Im Anschluss daran besuchte ich die Yarmauk University in Irbid welche ich mit dem Titel B.Sc abschloss. Im Jahr 1990 wechselte ich zur University of Jordan in Amman, wo mir 1995 der Titel M.Sc. in Chemie verliehen wurde. Von 1995 bis Ende 1998 war ich als „faculty member“ des Medical Science Fachbereichs der Al Isra University in Amman angestellt. Seit

Februar 1999 fertige ich unter der Leitung von Herrn Prof. Dr. Armin de Meijere meine Doktorarbeit an. 